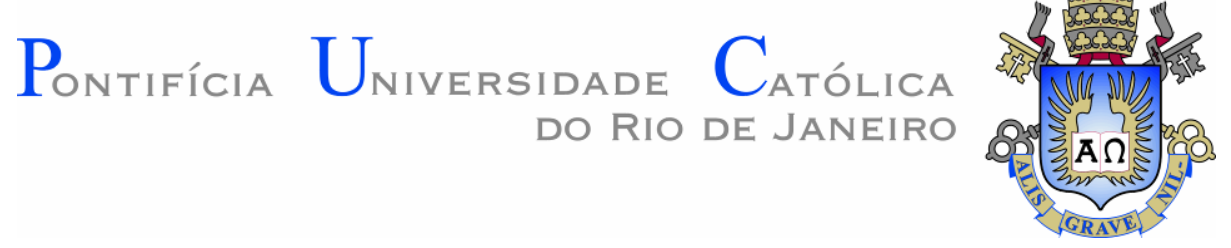

Adrian Evelyn Lima Henriques

\title{
EDUCAÇÃO, CONSERVADORISMOS E RELIGIÃO \\ Mapeamento e análise do avanço neoconservador na educação brasileira
}

Tese de Doutorado

Orientador: Prof. Dr. Pedro Teixeira Coorientador: Prof. Dr. Luís Fernando Dorvillé

Rio de Janeiro,

julho de 2021 
Educação, Conservadorismos e Religião: Mapeamento e Análise do Avanço Neoconservador na Educação

Brasileira

Tese apresentada como requisito parcial para obtenção do grau de Doutor pelo Programa de Pós-graduação em Educação do Departamento de Educação do Centro de Teologia e Ciências Humanas da PUC-Rio. Aprovada pela Comissão Examinadora abaixo assinada.

Prof. Pedro Pinheiro Teixeira Orientador Departamento de Educação - PUC-Rio

Prof. Luís Fernando Marques Dorvillé Coorientador UERJ

Prof.. Alicia Maria Catalano de Bonamino Departamento de Educação - PUC-Rio

Prof. José Antônio Miranda Sepúlveda UFF

Prof. a. Sandra Lúcia Escovedo Selles UFF

Prof. a. Maria Inês Galvão Flores Marcondes de Souza Departamento de Educação - PUC-Rio 


\section{Adrian Evelyn Lima Henriques}

Possui graduação em Ciências Biológicas pela Universidade do Estado do Rio de Janeiro (2013), especialização em Educação Básica, com ênfase em Ensino de Biologia (2014). Mestrado em Ensino de Ciências, Sociedade e Ambiente pela Faculdade de Formação de Professores da Universidade do Estado do Rio de Janeiro - UERJ/FFP (2016), tendo sido bolsista da CAPES. Cursou, como bolsista da CAPES, o Doutorado em Ciências Humanas - Educação na Pontifícia Universidade Católica do Rio de Janeiro - PUC-RIO.

Ficha Catalográfica

Henriques, Adrian Evelyn Lima

"Educação, conservadorismos e religião : mapeamento e análise do avanço neoconservador na educação brasileira" / Adrian Evelyn Lima Henriques ; orientador: Pedro Pinheiro Teixeira ; co-orientador: Luís Fernando Marques Dorvillé. - 2021. 235 f. : il. color. ; $30 \mathrm{~cm}$

Tese (doutorado)-Pontifícia Universidade Católica do Rio de Janeiro, Departamento de Educação, 2021.

Inclui bibliografia

1. Educação - Teses. 2. Educação. 3. Neoconservadorismo. 4. Religião. I. Teixeira, Pedro Pinheiro. II. Dorvillé, Luís Fernando Marques. III. Pontifícia Universidade Católica do Rio de Janeiro. Departamento de Educação. IV. Título. 
Para meus filhos, Otávio e Olívia, motivos pelos quais sigo em frente e exijo mudanças.

Para Elton, companheiro de todas as horas, por ter acreditado antes mesmo de mim.

Para Luís, mestre e amigo, que me apontou lá trás o caminho e disse "vamos juntos?". 


\section{Agradecimentos}

A escrita de uma tese quase sempre é comparada a uma gestação e sua defesa a um parto. Como orgulhosa mãe de duas adoráveis crianças posso confirmar que o desenvolvimento deste trabalho de doutoramento envolveu todos os elementos comuns aos processos mencionados acima: preocupações, angústias, surpresas, dores e, sobretudo em seu término, um alívio só compreendido por quem já vivenciou a mesma experiência. E se é do conhecimento de todos que é preciso toda uma aldeia para criar um filho, também é preciso dizer que nenhuma tese se escreve sozinha. Esta em especial contou com o apoio de pessoas maravilhosas as quais venho agradecer com todo carinho e gratidão desse mundo.

Ao meu orientador Pedro Teixeira, que "me herdou" após o falecimento do nosso querido Marcelo e foi sempre atento, dedicado, paciente, companheiro e firme no propósito de realizarmos um bom trabalho. Muito obrigada, Pedro, você fundamental ao longo desse processo! Muito obrigada!

Ao meu coorientador Luís Dorvillé, parceiro em minha caminhada acadêmica desde a graduação. Com você aprendi muito mais do que escrever trabalhos de maneira acadêmica e fazer análises conjunturais... Muito obrigada pela amizade, confiança, investimento e companheirismo em todos esses anos!

Às professoras Alicia Bonamino, Sandra Selles Escovedo, por participarem dessa escrita através das contribuições nas bancas de qualificação I e II. Seus apontamentos foram sempre precisos e pertinentes. Por aceitarem compor essa banca de defesa, agradeço aos professores Maria Inês Marcondes e José Antônio Sepúlveda. Suas contribuições são aguardadas com muita expectativa.

Aos amigos da turma de doutorado ingressantes em 2017.1, Adriena Casini, Aldenira Mota, Elise de Moraes, Ivo Fernandes, Isabel Mendes, Luísa Villard, Liliane Albuquerque, Marcus Vitói, Maria Paula Rossi e Sirlene Souza. Muito obrigada pela amizade, disposição para troca e acolhimento nessa nossa caminhada. 
Nosso apelido carinhoso, "turma 171", funciona pelo trocadilho, mas não poderia estar mais longe da realidade.

Aos companheiros do Diversias, muito obrigada pela escuta atenta e inúmeras trocas. Que o grupo de pesquisa continue crescendo e que siga sendo esse espaço acolhedor de debate, produção e afetividade. A participação de vocês na criação da base de dados que integra essa pesquisa foi valiosa.

A todos os amigos e familiares que torceram por mim e entenderam meu afastamento nos últimos anos. Não foi fácil!

Quero agradecer em especial às queridas Aline Machado, Ingrid Gomes e Luana Magalhães pelo suporte multidimensional ao longo dos últimos anos. A amizade, as risadas, os debates teórico-metodológicos, as discussões sobre os mais diversos assuntos... sem vocês teria sido impossível ir adiante em muitos momentos. Obrigada demais!

A Carlos Alberto, melhor e mais sábio pediatra que conheço, por estar sempre disponível, nunca errar um diagnóstico/tratamento e por ter dito a coisa certa na hora certa. Não sei agradecer o suficiente!

Às titias Hanna, Izabella, Suellen, aos titios Douglas e Helio, às avós Jandira e Adriana e ao avô Caetano, sempre dispostos a ajudar com as crianças nos momentos mais difíceis em que a mãe deles não podia dar toda atenção necessária...Não sei explicar o quanto sou grata!

Ao meu marido Elton, por estar sempre ao meu lado, acreditar antes mesmo de mim, ser meu primeiro ouvinte e maior apoiador. Essa conquista também é sua!

Aos professores e ao corpo técnico do Programa de Pós-Graduação em Educação da PUC-Rio.

O presente trabalho foi realizado com apoio da Coordenação de Aperfeiçoamento de Pessoal de Nível Superior - Brasil (CAPES) - Código de Financiamento 001. Muitíssimo obrigada a todos! 


\section{Resumo}

Henriques, Adrian Evelyn Lima Henriques. Educação, conservadorismos e religião: mapeamento e análise do avanço neoconservador na educação brasileira. Rio de Janeiro. 2021. 235p. Tese de Doutorado - Departamento de Educação, Pontifícia Universidade Católica do Rio de Janeiro.

Esta tese busca mapear e analisar os principais elementos envolvidos na atuação neoconservadora sobre a educação nacional. Investiga-se tendências, inclinações, valores e objetivos relacionados à logica conservadora e sua influência sobre o projeto político educacional brasileiro. Discute-se, também, o lugar ocupado pela religião nesse contexto. A hipótese que sustenta esse trabalho é a de que o neoconservadorismo em ascensão no Brasil utiliza a educação como campo privilegiado para a difusão de valores morais, religiosos, meritocráticos e securitários, na tentativa de esvaziamento do ambiente escolar de seu componente político e emancipatório. O referencial teórico utilizado nesta pesquisa articula autores nacionais e internacionais como Ronaldo Almeida, Marina Lacerda, Noël O'Sullivan e Michael Apple, embasando o entendimento de que a ativismo neoconservador brasileiro se inspira em movimentos de semelhante natureza oriundos de outros país, especialmente dos Estados Unidos da América dos anos 1970 e 1980, adaptando-o às próprias especificidades. Assim como no contexto original, a educação passa a ocupar um lugar de grande relevância e interessa, dada sua capilaridade e importância social. A abordagem metodológica utilizada é a Análise de Conteúdo (BARDIN, 2016) de um conjunto de documentos: iniciativas parlamentares relacionadas à educação propostas entre os anos 2001 e 2020 na Câmara de Deputados, o Manifesto à Nação Brasileira produzido pela Frente Parlamentar Evangélica em 2018, o discurso de posse do atual presidente Jair Bolsonaro e o decreto de implementação de escolas cívico militares, de sua autoria. Os resultados confirmam a hipótese inicial ao indicarem o crescimento de propostas de natureza conservadora ao longo dos anos analisados em torno de temas como sexualidade, religião, educação domiciliar, doutrinação escolar e patriotismo. Em última análise o trabalho evidencia que o que se está em disputa são diferentes projetos de sociedade e democracia que atravessam debates sobre família, laicidade, diversidade e objetivos educacionais. Suas implicações para educação apontam um caminho de autocensura docente, cerceamento do pluralismo de ideias e o rompimento dos limites entre público e privado, conhecimento e opinião. A conclusão deste texto traz a síntese das ideias discutidas e o apontamento de desdobramentos futuros, tais como as implicações dos resultados obtidos para o ensino de conteúdos disciplinares como evolução biológica, reprodução e sexualidade. Temas que interessam ao patrulhamento ideológico religioso da atuação neoconservadora educacional.

Palavras-Chaves: Educação, Neoconservadorismo, Religião. 


\section{Abstract}

Henriques, Adrian Evelyn Lima Henriques. Education, conservatism and religion: mapping and analysis of the neoconservative advance in Brazilian education. Rio de Janeiro. 2021. 235p. Tese de Doutorado - Departamento de Educação, Pontifícia Universidade Católica do Rio de Janeiro.

This thesis analyzes the main elements involved in the neoconservative action on national education. It investigates trends, inclinations, values and objectives related to conservative logic and its influence on the Brazilian educational political project. It also discusses the place occupied by religion in this context. The hypothesis that supports this work is that the rising Neoconservatism in Brazil uses education as a field for the dissemination of moral, religious, meritocratic and security values, to empty the school environment of its political and emancipatory component. The theoretical framework articulates national and foreign authors such as Ronaldo Almeida, Marina Lacerda, Noël O'Sullivan and Michael Apple. Upon these works, we argue that Brazilian neoconservative activism is inspired by similar movements from other countries, especially from the United States of America in the 1970s and 1980s, adapting it to Brazil's own specificities. As in the original context, education now occupies a place of great relevance and interest, given its capillarity and social importance. The methodological approach used is Content Analysis (BARDIN, 2016) of a set of documents: parliamentary initiatives related to education proposed between the years 2001 and 2020 in the Brazilian Chamber of Deputies, the Manifesto to the Brazilian Nation produced by the Evangelical Parliamentary Front in 2018, the inauguration speech of the current president Jair Bolsonaro and the decree implementing military civic schools. The results confirm the initial hypothesis by indicating the growth of conservative proposals over the years related to themes such as sexuality, religion, home education, school indoctrination and patriotism. Ultimately, the work shows that different projects of society and democracy are in dispute involving controversies about family, secularity, diversity, and educational aims. Its implications for Education point to teacher silencing, limiting the pluralism of ideas and breaking the boundaries between public and private, knowledge and opinion. The conclusion of this text synthetizes the ideas discussed and the points out future developments, such as the implications for the teaching of topics as biological evolution, reproduction, and sexuality. Themes that are of interest to religious ideological patrolling of neoconservative educational activities.

Keywords: Education, Neoconservatism, Religion 


\section{Sumário}

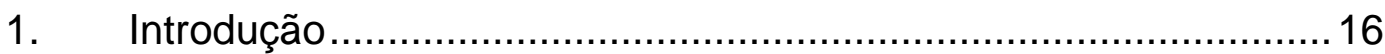

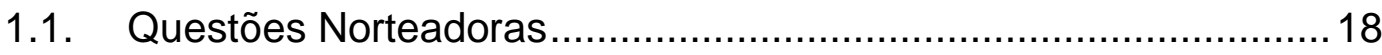

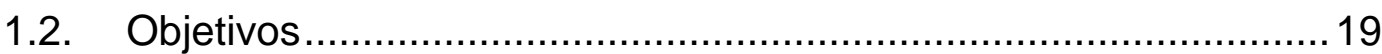

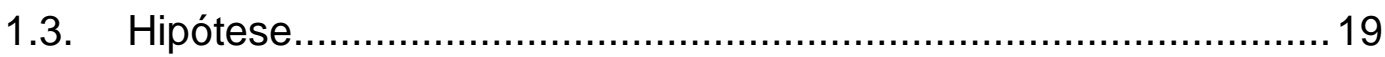

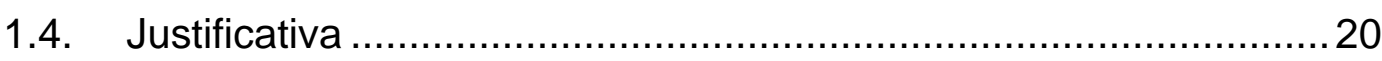

1.5. Estrutura e Nota Metodológica ...................................................2 23

2. Conservadorismo(s): histórico, filosofias e escolas de pensamento 27

2.1. As escolas do pensamento conservador: matizes, conceitos e

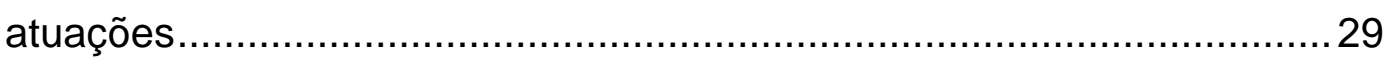

2.2. Neoconservadorismo: dinâmicas, valores e influências da nova

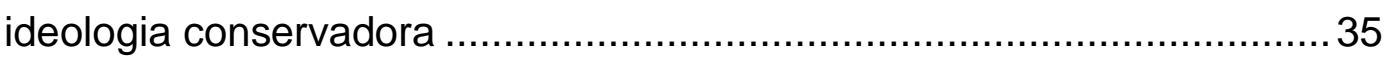

2.3. Conservadorismo à brasileira: ressurgimentos e atualizações ......41

3. A educação como um campo em disputa: o conservadorismo

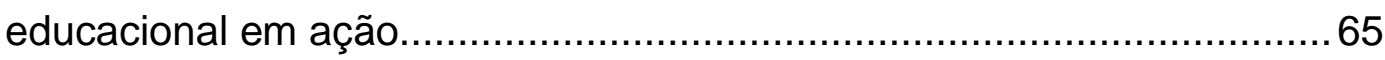

3.1. Racionalidade econômica e restauração cultural: os objetivos da modernização educacional conservadora ...............................................66

3.2. A educação brasileira em jogo: os tentáculos do neoconservadorismo educacional em ação ............................................ 72

4. Revisão de literatura: o que o campo tem a dizer..........................76

4.1. Etapas e procedimentos da revisão de literatura ............................76

4.2. Comunicação dos achados da revisão: tendências e abordagens do neoconservadorismo educacional no Brasil e no mundo .......................... 84

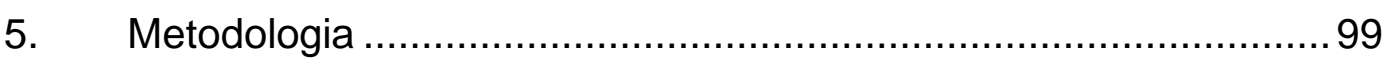

5.1. Percurso metodológico: entre o pretendido e o realizado...............99 
5.2. Levantamento das iniciativas parlamentares: a construção da base de dados.

5.3. Trechos e contextos: a análise dos 'imbróglios' relacionados ao PNE, à BNCC e à Reforma do Ensino Médio ................................................. 103

5.4. O manifesto, o discurso e o programa: a análise de outras fontes de influência (e poder).......................................................................... 104

5.5. O tratamento analítico: perspectivas teóricas e aspectos práticos 106

6. Análise e discussão dos resultados 110

6.1. Atuação parlamentar em números: tendências, inclinações e agentes.

6.2. Ativismo moralmente regulador e socialmente intolerante: a influência religiosa sobre a educação ................................................. 152

6.3. Ativismo economicista neoliberal: a educação como insumo ......173

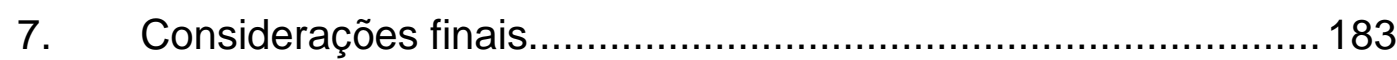

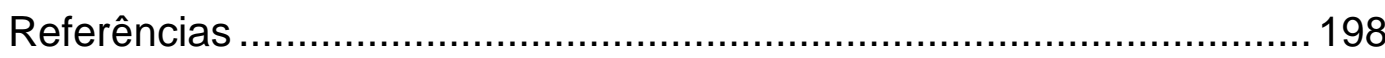

APÊNDICE A - Corpus do levantamento bibliográfico internacional .....224

APÊNDICE B - Corpus do levantamento bibliográfico nacional ............227

APÊNDICE C - Lista de iniciativas parlamentares conservadoras relacionadas à educação 228

APÊNDICE D - Lista de iniciativas progressistas relacionadas à educação 232

APÊNDICE E - Lista de iniciativas parlamentares ambíguas relacionadas à educação 235 


\section{Lista de siglas e abreviações}

BANCADA BBB - Bancada Boi, Bala e Bíblia

BDTD - Biblioteca Digital de Teses e Dissertações

BNCC - Base Nacional Comum Curricular

CAPES - Coordenação de Aperfeiçoamento de Pessoal de Nível Superior

CDHC - Comissão de Direitos Humanos e Cidadania da Câmara dos Deputados

COVID 19 - Coronavirus Disease 2019

ESP - Escola sem Partido

EUA - Estados Unidos da América

IBGE - Instituto Brasileiro de Geografia e Estatística

INC - Indicações da Câmara

LDB - Lei de Diretrizes e Bases da Educação

LGBT - Lésbicas, Gays, Bissexuais, Transsexuais

MESP - Movimento Escola sem Partido

OGNs - Organizações não Governamentais

SciELO - Scientific Eletronic Library Online

STF - Supremo Tribunal Federal

PDC - Projeto de Decreto da Câmara

PDL - Projeto de Decreto da Câmara

PEC - Proposta de Emenda à Constituição

PECIM - Programa Nacional de Escola Cívico Militares

PL - Projeto de Lei

PLC - Projeto de Decreto do Legislativo

PNE - Plano Nacional de Educação

PODE - Podemos

PP - Progressistas

PR - Partido da República

PROS - Partido Republicano da Ordem Social

PRTB - Partido Renovador Trabalhista Brasileiro

PSB - Partido Socialista Brasileiro

PSC - Partido Social Cristão

PSD - Partido Social Democrático

PSDB - Partido da Social Democracia Brasileira 
PSL - Partido Social Liberal

PSOL- Partido Socialismo e Liberdade

PT - Partido dos Trabalhadores

PTB - Partido Trabalhista Brasileiro

PTC- Partido Trabalhista Cristão 


\section{Lista de figuras}

Figura 1: As linhas de força do novo conservadorismo brasileiro segundo Ronaldo Almeida (2017). FONTE: A AUTORA ….......................................50 Figura 2: Integrantes da aliança conservadora na educação e seus principais integrantes, segundo Michael Apple (2002)............................................66 Figura 3: Proporção de textos encontrados no levantamento bibliográfico realizado. FONTE: AUTORA (2021). 81

Figura 4: Distribuição de textos por tipos encontrados em cada banco de dados utilizado no levantamento bibliográfico. FONTE: AUTORA, 2021. .82 Figura 5: Distribuição anual de pesquisas relacionadas ao (neo)conservadorismo educacional ao longo do período analisado. FONTE: AUTORA (2021).........82 Figura 6: Publicações relacionadas ao (neo)conservadorismo educacional no cenário internacional 83

Figura 7: Temáticas encontradas no levantamento bibliográfico sobre o cenário brasileiro. FONTE: AUTORA (2021) .87

Figura 8: Temáticas encontradas no levantamento bibliográfico sobre o cenário internacional. FONTE: AUTORA (2021). .93

Figura 9: Composição do corpus de análise 100

Figura 10: Temas gerais e palavras-chaves pesquisados no mecanismo de busca do endereço eletrônico da Câmara dos Deputados 102 Figura 11: Dimensões analisadas nos documentos oficiais PNE, BNCC, lei $13.415 / 2017$. 104

Figura 12: Dimensões a serem analisadas no Manifesto à Nação, nos Discursos de Posse de Jair Bolsonaro e no PECIM 105

Figura 13:Ilustrativo das etapas do método de análise de conteúdo segundo Bardin (2016) utilizadas nesta pesquisa 106

Figura 14: Classificação das iniciativas parlamentares segundo a natureza das proposições. Fonte: a autora a partir de dados do site da Câmara dos Deputados. FONTE: AUTORA (2021)

Figura 15: Número de proposições separadas por natureza entre os anos 20022012. FONTE: AUTORA (2021)

Figura 16: Número de proposições separadas por natureza entre os anos 20132020. FONTE: AUTORA (2021) 116 
Figura 17: Temas das iniciativas parlamentares conservadoras identificadas entre 2001 - 2020. FONTE: AUTORA (2021) 118

Figura 18: Lugar ocupado pela educação segundo as temáticas encontradas. FONTE: AUTORA:2021

Figura 19: Número de proposições conservadoras segundo as temáticas abordadas divido por período analisado. FONTE (AUTORA, 2021). 127

Figura 20: Temas das proposições relacionadas à consideradas progressistas encontradas entre 2001-2020. 131

Figura 21: Frequência de proposições por tema divididas por período analisado

Figura 22: Posição ocupada pela educação nas temáticas de natureza progressistas analisadas. FONTE: AUTORA (2021)

Figura 23: Frequência dos partidos que apresentaram proposições conservadoras, de acordo com o primeiro autor de cada proposição. FONTE: AUTORA (2021) 145

Figura 24: Frequência dos partidos que apresentaram proposições progressistas, de acordo com o primeiro autor de cada proposição. FONTE: AUTORA. ... 148 Figura 25: Lista de partidos aos quais autores proponentes de iniciativas ambíguas são filiados. FONTE: AUTORA (2021). 149 
Se a educação escolar envolve uma seleção de valores, a questão é quais os critérios para selecionar uns e não outros. Uma seleção que não respeita a dignidade de todos e todas não é legitima.

Marcelo Andrade

É o final dos tempos, alvos templos Salvos, mesmo, nenhum de nós Às vésperas de um grande salve-se quem puder Sendo tratadas como um dia qualquer... Leandro Roque de Oliveira - Emicida 


\section{Introdução}

Nos últimos anos, o Brasil viu crescer em número e expressão demandas por alterações no regime político vigente. Mobilizados por uma pauta "antissistema" e "contra tudo que está aí", sobretudo a partir de 2013, cada vez mais manifestantes foram as ruas exigir o fim da corrupção. Pedidos relacionados ao endurecimento do sistema penal e maior moralização das relações sociais ganharam as diferentes mídias e chegaram ao debate cotidiano da nação como um todo (TATAGIBA, 2018).

No cenário pós-eleições presidenciais de 2014, diferentes agentes movimentaram-se no Legislativo e no Executivo a fim de mobilizar a sociedade civil em torno da fragmentação do campo democrático-popular. Liberais, lideranças religiosas, agentes ligados à segurança pública e ao armamento populacional, bem como, outras categorias e instituições descontentes, compõem aquilo que se convencionou chamar de "onda conservadora brasileira". Tal movimentação ocasionou o impeachment de Dilma Rousseff em 2016, criando um vácuo de poder (BURITY, 2018).

Após um período de intensa polarização social, o país assistiu à queda de Dilma Rousseff, em 2016, à guinada neoliberal implementada pelo ex-vicepresidente, Michel Temer, e, por fim, à ascensão de Jair Bolsonaro ao poder em 2019. Autodeclarado conservador e fortemente relacionado às lideranças evangélicas, o atual presidente buscou mostrar-se como um agente da chamada nova política, mesmo tendo atuado como deputado federal por trinta anos ${ }^{1}$. "Conservador nos costumes, liberal na economia", bordão adotado por apoiadores, e o slogan de campanha presidencial, "Brasil acima de tudo, Deus acima de todos", sintetizam o projeto político de sua gestão: a defesa de uma rígida pauta moral articulada à mínima intervenção estatal em assuntos econômicos (LACERDA, 2019).

\footnotetext{
${ }^{1}$ Biografia de Jair Bolsonaro como deputado federal: Deputado(a) Federal - (Congresso Revisor), 1991-1995, RJ, PDC, Data. Posse: 01/02/1991; Deputado(a) Federal - 1995-1999, RJ, PPR, Data. Posse: 01/02/1995; Deputado(a) Federal - 1999-2003, RJ, PPB, Data. Posse: 01/02/1999; Deputado(a) Federal - 2003-2007, RJ, PPB, Data. Posse: 01/02/2003; Deputado(a) Federal - 2007 2011, RJ, PP, Data. Posse: 01/02/2007; Deputado(a) Federal - 2011-2015, RJ, PP, Data. Posse: 01/02/2011; Deputado(a) Federal - 2015-2019, RJ, PP, Data. Posse: 01/02/2015. Disponível em: https://www.camara.leg.br/deputados/74847/biografia. Acesso em 16/06/2010.
} 
No que se refere especificamente ao campo educacional, a agenda conservadora ganhou espaço político e defensores. Discursos inflamados sobre como a escola se tornou um espaço de "doutrinação política e ideológica" e "subversão de valores" ganharam materialidade e integram não apenas discursos, mas também projetos de lei e propostas curriculares (MARAFON; SOUZA, 2018). Um dos principais argumentos utilizados pelo próprio Jair Bolsonaro, ao longo de sua campanha presidencial, foi a necessidade de resguardar a inocência das crianças em idade escolar. A exposição dos jovens à doutrinação seja ela à ideologia marxista e/ou de gênero, segundo ele, foi uma das estratégias de subversão dos valores tradicionais acionadas pelos governos de esquerda. Uma ação orquestrada durante as gestões dos mandatários filiados ao PT - Partido dos Trabalhadores Dilma Rousseff e Luís Inácio Lula da Silva².

É importante lembrar, no entanto, que o discurso conservador relacionado à educação não nasce com o Bolsonarismo ${ }^{3}$. Sendo uma área estratégia, a função social da escola encontra-se historicamente em disputa. Articulações com objetivo de influir direta e indiretamente sobre as políticas educacionais, currículos e práticas de ensino à direita decorrem, segundo Michael Apple (2003), do projeto de modernização conservadora da educação. Segundo o autor, esta resulta da aliança estabelecida no início dos anos 1970 entre quatro grupos fundamentais nos Estados Unidos: neoliberais, neoconservadores, populistas autoritários religiosos e a nova classe média profissional. Apesar de origens diferentes e objetivos aparentemente não relacionáveis, tais grupos movimentam-se no sentido da desfragmentação do estado de bem-estar social. Tal movimentação ficou conhecida como ascensão neoconservadora e teve implicações políticas, sociais e culturais não somente nos EUA, como também em outras partes do mundo.

Marina Lacerda (2019) argumenta que existe, pelo menos desde 2015, um movimento de orientação política neoconservadora na política brasileira. Segundo a autora, é possível observar com clareza a atuação da direita política brasileira,

\footnotetext{
${ }^{2}$ Bolsonaro atribui a gestão da presidente petista Dilma Rousseff e a Fernando Haddad, então Ministro da Educação, a autoria de material escolar que promoveria a "ideologia de gênero", o "Kit Gay”. Disponível e: https://brasil.elpais.com/brasil/2018/10/12/politica/1539356381_052616.html. Acesso em 16/06/2020.

${ }^{3}$ Nome atribuído ao conjunto de políticas, ações, concepções e defensores de Jair Bolsonaro. Disponível em https://www.sul21.com.br/opiniaopublica/2020/01/bolsonarismo-movimento-ou-neologismo-por-christianvelloso-kuhn/ Acesso em 22/06/2020.
} 
sobretudo cristã, em torno de pautas como: i. valores religiosos aplicados à moralização das relações sociais, ii. neoliberalismo econômico, iii. endurecimento penal punitivista, iv. ativismo militar anticomunista, e, finalmente, iv. defesa sionista como parte da política externa. Este movimento espelharia em muitos aspectos o movimento neoconservador estadunidense, bem como, adaptaria outros tantos à realidade brasileira atual.

Nesta tese recorro aos termos conservadorismo e neoconservadorismo não como categorias de acusação, tal como se pode observar em utilizações comuns em debates e redes sociais, mas sim como potentes conceitos teóricos que potencializam as discussões sobre o avanço de demandas específicas na sociedade brasileira atual (ALMEIDA, 2017). Acredito que pensar quem são e como agem os agentes neoconservadores, quais os valores orientam certas pautas e práticas, bem como quais as consequências da imposição destes para a educação nacional favorece o entendimento de dinâmicas em curso nesse espraiamento do conservadorismo sobre a política pública educacional.

Assim, explicito o argumento que venho desenhando ao longo desta introdução: É consenso no campo progressista que as investidas neoconservadoras podem comprometer a qualidade da formação dos educandos de todo país. Estas agendas colocam os professores em suspeita, compreendem o processo de ensinoaprendizagem como a simples transmissão de conhecimentos neutros e ignoram as separações existentes entre espaço privado e público (CARA, 2016; CUNHA, 2017; PENNA, 2018; GOMES; HYPÓLITO, 2019; LOUZANO; MORICONI, 2019).

Esclarecidas as questões introdutórias mais gerais, apresento a seguir as questões norteadoras, objetivos, hipótese e justificativa que sustentam essa investigação. Ao final está a apresentação da estrutura do trabalho como um todo e uma pequena síntese do que esperar dos capítulos seguintes.

\subsection{Questões Norteadoras}


As questões a seguir apresentam as inquietações que orientam essa investigação. É a partir delas que irei olhar para o fenômeno social do conservadorismo na educação.

Quais os agentes, discursos e objetivos relacionados à lógica conservadora brasileira na educação? Que valores e objetivos os movem?

Qual é o lugar ocupado pela religião nesse contexto político e social?

\subsection{Objetivos}

A busca por respostas e entendimento exige clareza dos propósitos intencionados em uma pesquisa. Por isso os divido em:

\section{Objetivo Geral}

Mapear a atuação neoconservadora sobre a educação nacional entre os anos 2002 e 2020.

\section{Objetivos Específicos}

i. Identificar os principais elementos que compõem os programas e ações conservadoras em curso no cenário educacional brasileiro.

ii. Discutir as lógicas e valores que embasam argumentações conservadoras no campo educacional.

iii. Refletir sobre os possíveis impactos das agendas conservadoras sobre a educação nacional.

\subsection{Hipótese}

A hipótese que sustenta este trabalho é de que o neoconservadorismo brasileiro utiliza a educação como campo privilegiado para a difusão de seus valores e ideias. Para tanto lança mão de discursos morais, religiosos, meritocráticos e securitários, na tentativa de esvaziamento do ambiente escolar seu componente político e emancipatório. 


\subsection{Justificativa}

Qual é espaço ocupado pelo conservadorismo na educação? Como educar para convivência democrática em uma realidade crescente de polarização e intolerância? Neste trabalho busco trazer elementos para discutir estas e outras questões relacionadas à educação brasileira e à influência conservadora sobre o espaço público. Para desenvolver tal discussão, tomo como material de análise documentos que expressam a dinâmica conservadora educacional. A partir deles, busco encontrar lógicas de atuação expressas em seus argumentos, atos decisórios e manifestos.

Cada vez mais pesquisas recorrem à história do neoconservadorismo para analisar o avanço das demandas conservadoras na sociedade brasileira atual. Bezerra Neto e Bezerra (2016), o fazem para pensar a tendência de sucateamento e precarização da educação no campo. Para ambos, ao buscar silenciar o professor em sala de aula, os projetos neoconservadores atuam no sentido de diminuir as oportunidades de construção crítica de pensamentos sobre a realidade. Aplicadas à educação no campo - um lócus educacional voltado para a integração sociocultural e política de seus educandos e, por tanto, muitas vezes ligadas aos movimentos sociais - as estratégias de silenciamento, burocratização e esvaziamento político dos processos de ensino-aprendizagem nas propostas conservadoras, tal como o Programa Escola Sem Partido, ao qual abordarei com mais detalhe futuramente, facilitam a cooptação dos educandos, deixando-os expostos às investidas do agronegócio e carentes de elementos que lhes permitam reivindicar seus direitos em situações de vulnerabilidade.

As alianças estabelecidas entre defensores de interesses neoliberais e perspectivas educacionais conservadores também figuram como um elemento importante nesse bojo. Para Gonzales e Costas (2017), a mídia se alia aos agentes neoliberais e conservadores a fim de difundir, seduzir e convencer acerca da desresponsabilização do Estado. No que se refere à educação, essa aliança combina a retórica da inovação modernizadora e ânsias por ordem e progresso. Aparentemente contraditórias, tal articulação aposta em reformas gerenciais técnicas, instrumentalização do processo educacional e nivelamento via meritocracia. Para ambos, o Programa Escola Sem Partido é um exemplo dessa abordagem, pois defende um projeto de sociedade excludente, patriarcal e acrítico, 
favorecendo, em um contexto geral, a manutenção das relações sociais tais como são calcadas na exploração das classes trabalhadoras.

A influência do neoconservadorismo nos discursos sobre gênero também compõe esse arco de discussão. Após analisar 244 pronunciamentos realizados por deputados federais eleitos em 2014 para o Congresso Nacional relacionados aos "ideologia de gênero" e "Escola sem Partido", Santos (2018) observa que a relação entre gênero e família nos discursos proferidos no plenário da Câmara é de extrema proximidade. De acordo com os deputados conservadores em seus discursos "a defesa da família" deve ser entendida como a primeira obrigação social e deve observar duas questões: formato e autoridade. O formato é o patriarcal, heterossexual, a chamada "família tradicional". Sobre a autoridade, os posicionamentos familistas advogavam o direito de os pais educarem seus filhos de acordo com seus valores morais e religiosos (desde que estes fossem os valores cristãos). O ativismo contra a doutrinação escolar foi identificado por Santos (2018) nos pronunciamentos favoráveis ao movimento Escola sem Partido. Segundo esses discursos, a escola seria um local propício à doutrinação ideológica (doutrinação de esquerda) e de gênero (perversão do sexo biológico em favor de orientações sexuais outras). Em ambos os casos, argumentos religiosos foram mobilizados para sustentar tais posicionamentos.

A imagem da escola e do professor como fonte de doutrinação comunista é discutido por Paulino (2018). Ao analisar postagem realizadas por militantes e apoiadores do movimento Escola sem Partido em busca da imagem docente veiculada pelos mesmos, a autora aponta a utilização de "memes", "piadas", “caricaturas", entre outros materiais, como fonte de acusação e escárnio à figura dos professores. O legado de Paulo Freire é apontado como causa maior do problema da educação brasileira. Os governos petistas são reproduzidos como fonte de doutrinação comunista. Outros pensadores e figuras relacionadas a educação progressista e emancipatórias são apontados como comunistas doutrinadores. Segundo a autora, as postagens realizadas por militantes e apoiadores, mas também pelo próprio criador do movimento Escola sem Partido, Miguel Nagib, desinformam, destorcem e demonizam tudo aquilo que abominam. Ainda segundo Paulino, o conservadorismo defendido pelo Escola sem Partido supera inclusive àquele apresentado por seu patrono ideológico: os Estados Unidos, pois buscam inserir no ordenamento jurídico de toda a nação o cerceamento do debate, do 
pluralismo e da liberdade de ensinar e aprender, ultrapassando, assim, a tendência comportamental individualista dos norte-americanos. A autora finaliza com um convite aos educadores a luta contra o projeto conservador de sociedade defendido pelo Escola sem Partido.

Estes são apenas exemplos de discussões recentes sobre o assunto. Existem outros. No entanto estes foram escolhidos por utilizar os termos "conservadorismo" e "neoconservadorismo" como categorias de análise e não somente como adjetivo de acusação, ou de pouca utilização, tal como pretendo realizar neste trabalho de tese. Em seus escritos, tais autores buscaram pensar quem são e como agem os agentes neoconservadores no Brasil. Quais são seus valores, e quais as consequências de sua implementação para a educação nacional. Voltarei a olhar para as produções bibliográficas relacionadas ao tema a adiante. Nele buscarei mostrar o que está sendo produzido, pensado e analisado sobre a dinâmica "conservadorismo / neoconservadorismo / educação" no Brasil e no mundo através de uma revisão bibliográfica criteriosa realizada em bases de dados nacionais e uma internacional. É interessante observar, no entanto, que o movimento Escola sem Partido teve destaque em todos os textos apresentados como exemplo anteriormente. Apesar de não intencional, tal recorrência indica a preocupação de diferentes autores com o espraiamento do conservadorismo sobre a política pública educacional. Retornarei ao movimento Escola sem Partido futuramente, conforme já adiantado.

Assim, acredito que o poder de contribuição do trabalho realizado pode ser sintetizado em três frentes: i. a contribuição teórica realizada através da sistematização de conceitos oriundos de outros campos do saber e sua discussão relacional com o campo educacional, ii. a contribuição empírica obtida através do mapeamento de ações neoconservadoras materializadas em documentos distintos como proposições legislativas, contextos e tensões relacionadas a políticas públicas educacionais e discursos presidenciais, e, por fim, iii. a contribuição potencial de ampliação das discussões realizadas até então no campo e capacidade de inspiração de novas pesquisas e desdobramentos futuros.

$\mathrm{O}$ argumento central desta tese gira em torno da hipótese de que o neoconservadorismo brasileiro utiliza a educação como plataforma privilegiada para a difusão de seus valores e ideias. Entendo que a identificação de suas estratégias permite a construção de posturas de compreensão e enfrentamento que 
podem vir a favorecer, inclusive, àqueles que estão na outra ponta dessa equação, os professores e gestores que se encontram no chamado chão da escola e precisam lidar com as consequências diretas das ações em curso aqui discutidas. Esclarecidas estas disposições, passo à síntese dos capítulos que integram este documento

\subsection{Estrutura e Nota Metodológica}

Nos capítulos 2 e 3 apresento a fundamentação teórica que baliza as reflexões realizadas neste trabalho. Em um primeiro momento busco recuperar a história e a filosofia do termo conservadorismo. Sigo apresentando as atualizações e especificidades daquilo que chamo de novo conservadorismo (Capítulo 2). Em seguida, discuto os principais elementos relacionados à educação num cenário conservador (Capítulo 3). Apesar de utilizar diferentes autores e seus apontamentos, é possível destacar a influência das reflexões apresentadas por Noël O’Sullivan (2013) - conceituações relacionadas às escolas conservadoras; Marina Lacerda (2019) - discussões sobre as características do conservadorismo brasileiro vigente; Ronaldo de Almeida (2017) - mapeamento da atuação de forças conservadoras no âmbito educacional e Michael Apple (2002; 2003) - discussão sobre os valores e sujeitos da educação conservadora.

No Capítulo 4 trago a revisão de literatura realizada com o objetivo não somente de conhecer o campo de discussões sobre conservadorismo na educação, como também de produzir categorias de análise para a presente pesquisa. Ao analisar textos publicados tanto no Brasil, como em cenários internacionais, a revisão identificou que a posição ocupada pela educação como relevante nas discussões sobre o neoconservadorismo. Seja como espaço em disputa ou como vetor de valores, a escola básica e a educação superior surgem como espaços importantes dentro dessas reflexões.

Também foram identificadas temáticas de interesse, e apesar de apresentarem diferenças em suas classificações, as temáticas nacionais e internacionais evidenciam elementos semelhantes como relevantes: a diversidade sexual e cultural, a moralidade religiosa, os valores tradicionais, a atuação civil e institucional na avanço conservador em diferentes dimensões sociais, o apagamento dos limites entre público e privado, e a necessidade de reposicionamento da educação como lugar de enfrentamento, empoderamento e resistência. No que se 
refere às metodologias aplicadas, o levantamento destacou o investimento qualitativo e quanti-qualitativo em análises que vão desde o nível micro (o chão da escola no Brasil ou no Reino Unido) e macro (mapeamento de ações, percepções, atuações e fins em diferentes contextos e países).

O Capítulo 5 traz a abordagem metodológica. Nessa seção as particularidades envolvidas numa Análise de Conteúdo são discutidas (BARDIN, 2016). O conjunto de materiais analisados nessa pesquisa é composto por Projetos de Lei na Câmara dos Deputados, manifestos produzidos por frentes parlamentares, trechos e contextos de documentos oficiais norteadores do funcionamento e do currículo escolar, tais como o Plano Nacional da Educação (PNE), a Base Nacional Comum Curricular (BNCC). A partir da análise criteriosa destes materiais buscarei apontar convergências e divergências, agendas e agentes, valores e argumentos que sustentam o ativismo conservador na educação brasileira.

É importante mencionar que o desenho desta investigação precisou ser adaptado em virtude da pandemia Covid-19 (Coronavirus Disease 2019) ${ }^{4}$ que globalizou em 2020 e, ainda em 2021, permanece causando impactos em todo o mundo ${ }^{5}$. Em sua concepção original, o objetivo da pesquisa era encontrar ecos do conservadorismo educacional em uma escola pública estadual situada no munícipio de São Gonçalo (IBGE, 2010). O município integra a região metropolitana do Rio de Janeiro e apresenta forte pertencimento religioso cristão, sobretudo evangélico, por parte de sua população. Também chamados de protestantes, os evangélicos, junto à Igreja Católica e à Igreja Ortodoxa, integram o terceiro ramo do cristianismo. Divididos em subtipos (históricos, pentecostais e neopentecostais),

\footnotetext{
${ }^{4} \mathrm{O}$ vírus Coronavirus-SARS-COV-2 foi observado em dezembro de 2019 em Wuhan, China. Em setembro de 2020, mais de 25 milhões de pessoas foram contaminadas em todo mundo, assim como aproximadamente 800 mil óbitos foram registrados até então. Especialmente perigoso para pessoas idosas e portadoras de comorbidades (hipertensão, diabetes, obesidade, problemas respiratórios, entre outros), no Brasil, a doença pode ter sido agravada ainda mais pelas desigualdades sociais já que pessoas em condições de vulnerabilidade e pobreza foram as mais afetadas no país que já ultrapassou a marca de 100 mil mortos até o presente momento. Disponível em: https://noticias.uol.com.br/saude/ultimas-noticias/redacao/2020/05/06/no-brasil-covid-19-naomata-por-idade-mas-por-endereco-sugere-estudo.htm Acesso em 15/08/2020.

${ }^{5}$ Em maio de 2021, período de ajustes finais desta tese, 159 milhões de pessoas foram contaminadas em todo mundo pela Covid-19. O Brasil ocupa o triste posto de segundo país com maior número de óbitos por Covid-19, aproximadamente 428 mil mortes oficialmente notificadas, atrás apenas dos EUA com 583 mil mortes acumuladas durante a pandemia. Muito embora já existam vacinas disponíveis para a prevenção da doença, o Brasil encontra-se imerso numa crise política e humanitária que dificulta o manejo adequado pandêmico. Disponível em: https://brasil.elpais.com/brasil/2021-05-13/noticias-sobre-a-covid-19-e-a-crise-politica-aovivo.html. Acesso em 13/05/2021.
} 
apresentam diferenças na maneira como se apropriam dos evangelhos de Cristo e atuam na esfera pública (CUNHA et al, 2007). O avanço da presença, visibilidade e poder político desse ramo religioso e a afinidade de parcelas significativas do mesmo com movimentos de natureza conservadora sustentavam a justificativa de utilizar o munícipio de São Gonçalo como campo da pesquisa.

Previa-se, então, a observação de campo, aplicação e análise de questionários, e entrevistas com gestores, docentes e alunos. Após meses de espera e dificuldades burocráticas para ingressar na escola, a autorização chegou junto com as orientações de distanciamento social para contenção da pandemia. As escolas por todo país foram fechadas e migraram com maior ou menor sucesso para o ensino remoto. As redes públicas e privadas do Rio de Janeiro continuam fechadas até o momento em que esse texto é escrito. Desse modo, não restou qualquer alternativa a não ser reorientar a pesquisa. As leituras e referenciais foram mantidos, porém os objetivos e procedimentos metodológicos foram modificados. Tais modificações resultaram no texto que se apresenta neste trabalho.

Os resultados obtidos são apresentados no Capítulo 7. O objetivo dessa seção é discutir os achados da pesquisa a luz do referencial teórico. Dividida em dois momentos, a discussão de resultados realiza dois movimentos: Em primeiro lugar a análise quantitativa de 188 iniciativas parlamentares realizadas entre 2001 e 2020, sua separação em grandes categorias chamadas de "conservadoras", "progressistas" e "ambíguas" de acordo com a natureza das proposições e a descrição delas. Em seguida, a discussão qualitativa dos dados produzidos na primeira etapa somados a achados oriundos de outros documentos: PNE, BNCC, Manifesto à Nação e os discursos de posse de Jair Bolsonaro. Em síntese, a primeira aponta o avanço de propostas conservadoras a partir de 2013, período em que a insatisfação popular e demandas "antissistema" ganharam as ruas e foram cooptadas por forças e movimentos de direita e extrema direita. Entre as propostas de cunho conservador encontradas, aquelas voltadas para a sexualidade foram as mais frequentes, seguidas por religião, educação domiciliar/homeschooling, doutrinação e patriotismo, respectivamente. No que se refere à etapa qualitativa, foi possível identificar algumas categorias associadas à atuação neoconservadora relacionada à educação: o familismo, o combate à diversidade, a privatização do espaço público, inerentes ao ativismo moralmente regulador, securitário e socialmente intolerante, e educação como commodities e o sucesso/insucesso 
meritocrático, parte do ativismo economicista neoliberal. Estas linhas de atuação e seus integrantes se afastam e se aproximam de acordo com seus objetivos. Entretanto, muito embora possam atuar de maneira independente, os dados reforçam as discussões teóricas que indicam a articulação de interesses dentro de uma coalizão maior que disputa o poder decidir e legislar sobre tanto sobre perspectivas educacionais quanto a vida em sociedade em geral.

Por fim, o Capítulo 8 traz as considerações finais nele busco sintetizar o trabalho realizado e aponto os caminhos e desdobramentos futuros desta investigação. De modo geral os dados encontrados apontam questões imediatas sobre o projeto político de educação nacional: o apagamento de fronteiras entre questões privadas e interesse público, o combate à pluralidade de ideias, de comportamentos e de perspectivas de vida em sociedade, a demonização do diálogo livre, a diminuição do Estado e reorientação mercadológica educacional. Nesta seção reflito o potencial de impacto destas questões macro sobre as dimensões micro do processo educacional a partir da minha própria área de atuação, a educação em Ciências e Biologia: a desconfiança na relação professor-aluno, a censura de conteúdo, o antagonismo entre família e escolas, a excessiva preocupação com neutralidade e avaliações externas que podem impactar um processo de escolarização que se pretenda laico, plural e emancipatório. 


\section{Conservadorismo(s): histórico, filosofias e escolas de pensamento}

Diante da efervescência política atual, o adjetivo "conservador(a)" passou ser usado tanto de maneira pejorativa e de acusação, como de maneira positiva e auto elogiosa, a depender de quem lhe emprega. Nesse trabalho, contudo, procuro utilizá-lo como potência analítica capaz de relacionar configurações e complexidades socioculturais. Para tanto, busco num primeiro momento recuperar, brevemente, sua história e fundamentos filosóficos.

O conservadorismo (ou conservantismo) pode ser popularmente entendido como uma perspectiva política de aversão à mudança e forte ligação às coisas como são. Nesse contexto, mudanças abruptas da ordem social estabelecida são rechaçadas e combatidas por seus adeptos, visto que o único progresso possível é aquele que se fundamenta em valores e saberes previamente testados (CROWTHER, 1993).

A crítica conservadora à mudança pela mudança encontra origem em Edmund Burke (1729-1797), filósofo irlandês radicado na Inglaterra. Seus ideais foram revisitados ao longo do tempo e, ainda hoje, influenciam a ideologia conservadora. Ao lançar um longo manifesto contra a Revolução Francesa (17891799), Burke aponta que revolução insurrecional derrubou abrupta e violentamente um modo de vida estabelecido. Ocorrida um século antes, a Revolução Inglesa (1642-1651), para o filósofo e parlamentar britânico, exemplifica uma revolução não disruptiva ou destrutiva. Defensor da monarquia constitucional, Burke credita ao respeito às instituições e tradições a preservação dos valores sociais construídos ao longo do tempo (PIMENTEL, 2018).

Em Ideias Conservadoras, João Pereira Coutinho (2014) aponta que não existe um único conservadorismo, mas sim conservadorismos, no plural. Apesar de advogar em favor da manutenção da ordem social estabelecida, dos valores tradicionais e das convenções construídas historicamente, os conservadores podem divergir sobre o que conservar e o que descartar. Segundo Russel Kirk (19181994), o conservadorismo não estaria preso a uma ideologia fixa. Ao contrário, os diferentes modos de ser conservador se ajustariam as necessidades do contexto 
vigente. Assim, sobre as tensões existentes entre permanência e mudança, o historiador norte americano afirma que

o conservador não se opõe a melhorias sociais, embora duvide da existência de qualquer força semelhante a um progresso místico, com "P" maiúsculo, em ação no mundo. Enquanto uma sociedade progride em alguns aspectos, geralmente retrocede em outros. (...) A permanência de uma sociedade é o conjunto daqueles interesses que dão estabilidade e continuidade. Sem essa permanência, as fontes do grande abismo se rompem, jogando a sociedade na anarquia (KIRK, 1993, pág. 111, 112).

Para o cientista político e filósofo inglês, também conservador, Michael Oakeshott (1901-1944), a postura conservadora transcende a crença ou um conjunto de doutrinas. $\mathrm{O}$ conservadorismo seria, então, algo para além da prática política. Uma predisposição que acompanha o indivíduo conservador. Em suas palavras, ser conservador

...é preferir o familiar ao desconhecido, preferir o tentado ao não tentado, o facto ao mistério, o real ao possível, o limitado ao ilimitado, o próximo ao distante, o suficiente ao superabundante, o conveniente ao perfeito, a felicidade presente à utópica (OAKESHOTT, 2012, p.5).

Já para Roger Scruton (1944-2020), é a única resposta simultaneamente racional e emocional possível à ameaça trazida pelas realidades emergentes ao modo de vida ocidental. Em Como ser um conservador, o filósofo inglês aponta que

o conservadorismo é a filosofia do vínculo afetivo. Estamos sentimentalmente ligados às coisas que amamos e que desejamos proteger contra a decadência. Sabemos, contudo, que tais coisas não podem durar para sempre. Enquanto isso, devemos estudar os modos pelos quais podemos conservá-las durante todas as mudanças pelas quais devem inevitavelmente passar, de modo que nossas vidas continuem sendo vividas em um espírito de boa vontade e de gratidão (SCRUTON, 2015, Não paginado.).

A fim de operar com a categoria conservadorismo, opto por trazer as discussões elaboradas por Nöel O’Sullivan, professor da Universidade de Hull, Reino Unido. No verbete Conservatism do Oxford Handbook of Political Ideologies, O’Sullivan (2013) aponta o erro de entender o conservadorismo como uma anti-ideologia reativa e não propositiva. Em sua concepção, o conservadorismo moderno apresenta proposições: i. a defesa da limitação do poder político 
governamental e ii. a luta contra os anseios por mudanças políticas e sociais surgidos no Iluminismo e presentes ainda hoje no pensamento progressista.

\subsection{As escolas do pensamento conservador: matizes, conceitos e atuações}

É possível destacar, segundo O’Sullivan (2013), quatro escolas do pensamento conservador: 1) Reacionária; 2) Radical; 3) Moderada; 4) Nova Direita. Apesar de apresentarem proximidades, cada uma demonstra especificidades que devem ser mais bem elaboradas.

A escola reacionária aponta o consenso entre as instituições políticas e os valores morais e religiosos fundamentais como base estruturante da sociedade. De acordo Juan Donoso Cortes, conservador reacionário da primeira metade do século XIX, existem, então, duas formas de controle: religioso (interno) e político (externo). A dinâmica entre eles garantiria o equilíbrio social. Assim, se o controle religioso diminui - como em sociedades seculares e/ou laicas - o controle político passa a crescer, abrindo caminho para tiranos, que crescem no vazio espiritual. Tal evento criado pela crença na habilidade do ser humano de abandonar a religião e seguir a felicidade através da ação política criativa, erodiria as estruturas sociais, levando ao caos.

Já Charles Maurras, monarquista e antissemita francês da virada do século XIX para o XX, acreditava ser difícil atingir certo consenso sobre valores fundamentais num contexto social de democracia capitalista. Em seu ponto de vista, a ética egoísta e cruel própria dessa conjuntura substituiria a opressão aristocrática pela opressão da plutocracia dos negócios. Contemporâneo e próximo a Maurras, Maurice Barrès, político e escritor francês, estendia as reflexões reacionárias à educação. Em sua opinião, o ideal igualitário democrático emburreceria os padrões educacionais de tal forma a ponto de se tornar impossível transmitir uma herança comum a cada nova geração. O resultado seria o fim da própria civilização, pois o poder integrado da cultura levaria ao desenraizamento espiritual.

O’Sullivan (2013) ainda destaca que as principais críticas à escola reacionária se centram em seu caráter essencialmente esnobe em relação à análise política; ao desejo utópico de uma sociedade hierárquica perfeita e harmoniosa; a sua tendência à adesão de ideologias extremistas, algo que favorece teorias de 
conspiração associadas a um único fator (frequentemente remetidas aos judeus). Logo, tais movimentos costumam ficar relegados às margens da política, promovendo-se como suprapartidários. Não hesitam em lançar mão de expedientes extraconstitucionais na tentativa de derrubada da ordem social estabelecida, seja por via revolucionária, ou pela adoção de um conceito carismático de liderança que possa unificar o povo diante de uma representação democrática dividida.

Localizada no extremo oposto da escola reacionária, a escola radical insiste que um conservadorismo relevante deve abraçar positivamente a modernidade democrática ao invés de se mostrar hostil a ela. Para alcançar seus objetivos, as massas deveriam seguir líderes carismáticos capazes de unificar a população frente as divisões sociais e lutas de classe. A ideologia que surge desse ativismo funde nacionalismo e socialismo, e exige envolvimento político por parte de toda a nação. Dessa maneira, enquanto a escola reacionária se constrói "de cima para baixo" - de maneira elitista -, a radical é construída "de baixo para cima".

Seus primeiros proponentes foram pensadores do período entreguerras, críticos da República de Weimar e ficaram fortemente identificados com o Nazismo, como Carl Schmitt. Seus defensores tentaram torná-la uma escola mais respeitável no período pós-Segunda Guerra. Três estratégias intelectuais foram adotadas: rejeição do princípio do líder em sua forma individualizada; rejeição de uma doutrina nacionalista em favor de um ideal supranacional de unidade europeia como a principal salvaguarda contra a dominação dos EUA; rejeição de métodos políticos extraconstitucionais em favor de um programa gradualista de educação política em massa, afastando-se do totalitarismo fascista.

Sobre as principais críticas ao conservadorismo radical, três pontos se destacam: a fé em um líder nacional que é politicamente irreponsabilizável (unaccountable); a recusa em aceitar a tendência das populações modernas de não se tornarem politicamente envolvidas, o que acaba exacerbando a distância entre elites que se envolvem politicamente e a maioria indiferente; a demonização inevitável de grupos que se opõem ao líder como representante exclusivo da unidade nacional.

A terceira escola conservadora apontada por O'Sullivan (2013) é a moderada. Suas características principais são: comprometimento com um ideal de Estado limitado e regido pela lei; existência de instituições representativas e de uma constituição que controle o poder executivo. Apesar de apresentar interseções com 
a ideologia liberal, os conservadores rejeitam, os conceitos racionalistas abstratos. No espectro conservador, encontra-se entre a apatia social defendida pelos reacionários e a mobilização ativa das massas desejada pelos radicais.

O conceito de limite, no entanto, varia para os conservadores. Edmund Burke parte de um ponto de vista teológico: a fonte da moderação seria a estrutura ordenada do universo. Os ideais revolucionários para Burke constituíam não apenas uma loucura, como também uma blasfêmia ao plano divino, pois a hierarquia social e política integra o todo ordenado divinamente inspirado. Benjamin Constant, por sua vez, o concebe a partir de uma visão trágica: a natureza humana moderna está inevitavelmente dividida por interesses complexos que impedem o total comprometimento com um valor ou paixão singular. É impossível, portanto, alcançar um eu (self) unificado. Já David Hume adotava uma visão cética dos requisitos da prudência política, assumindo que, em assuntos políticos, todo homem é um possível patife/traidor (knave), quer seja de fato ou não. Isso implicaria na elaboração de vários pontos de checagem e controle da constituição. Com isso, os homens não seriam pegos de surpresa por abusos de poder na política, nem por fragilidades da ordem política e dos limites severos para a ação governamental.

Diferentes em suas abordagens teóricas, as linhas do conservadorismo moderado partilham o ideal de Estado limitado em sua ação política. As críticas à escola moderada, contudo, se centram na vinculação desta a uma visão orgânica de sociedade, na qual a ordem social tende a uma harmonia natural. Burke, por exemplo, se remetia a uma aristocracia natural, cuja autoridade assumiria aceitação universal. Mesmo no campo conservador, tais críticas emergiram. Samuel Taylor Coleridge, escritor inglês da virada do século XVIII para XIX, acreditava que, para que essa visão orgânica se sustentasse, seria necessário que houvesse maior intervenção estatal e distanciamento da liderança política aristocrática proposta por Burke.

Na Europa, no século XX, essa visão conservadora deu origem a uma "economia social de mercado" articulada a visões religiosas. Resultando, assim, em uma combinação de simpatia por políticas socialistas, rejeição de uma cultura humanista secular e ênfase conservadora em autoridade e instituições tradicionais, como família e igreja, característico de partidos democrata cristãos de Alemanha, Itália, Bélgica, Holanda e Luxemburgo na era do pós-guerra. 
A Nova Direita, quarta escola descrita por O’Sullivan (2013), surge em resposta ao desenvolvimento alcançado pela economia social de mercado anteriormente descrita. Ao ganhar influência sobre o pensamento conservador na Europa e nos Estados Unidos no período pós Segunda Guerra, a Nova Direita destaca-se como um importante agente social que merece ser discutido detalhadamente.

\section{A Nova Direita e o Novo Conservadorismo: influências filosóficas e atuação social}

No Reino Unido, o temor de que a constituição parlamentar estivesse sendo substituída por um sistema de governo corporativista surgiu nos anos 1970. Tal corporativismo, segundo os conservadores, consistiria em barganhas privadas entre governo, grandes industriais e sindicatos. Somava-se a isso problemas de ordem econômicas, tais como a inflação; questões sociais, como a crescente dependência de políticas de bem-estar; e, por último, mas não menos importante, a perda progressiva de uma identidade conservadora própria do país. Duas principais respostas foram propostas: i. reformulação da posição orgânica, e, ii. livre mercado.

A reformulação da posição orgânica encontra em Roger Scruton seu principal defensor. Para o filósofo, a restauração da centralidade política ao sentimento nacional era necessária e urgente. Tal sentimento teria sido descreditado pelo nacionalismo fascista na Segunda Guerra Mundial, e, depois, rechaçado pelo favorecimento pós-guerra de interesses supranacionais. Scruton via os Estados europeus modernos como entidades sociais distintas, "sociedades de estranhos" que não compartilham um genuíno senso de "nós", e que, portanto, não desenvolveram uma identidade nacional.

Ainda para o filósofo conservador, apenas o desenvolvimento de uma lealdade nacional partilhada poderia tornar diferentes membros parte de um só corpo. Scruton (2006) afirma, no entanto, que lealdade nacional difere de um nacionalismo beligerante, pois enquanto a primeira busca um consenso sobre o modo de vida, o último usa de símbolos nacionais para recrutar pessoas para as guerras. Tal perspectiva pretende unir religião e cultura em torno do contrato social burkiano, ou seja, de um modo de vida e de ação política que leve em consideração os mortos (antepassados), os vivos e as não nascidos (as gerações futuras). Para 
O’Sullivan (2013), a busca por esse difícil consenso torna a adesão a esse tipo meramente algo formal e legal.

A defesa do livre mercado encontrou em Frederich Hayek (1899-1992) os argumentos utilizados por seus adeptos. Por mais que o pensador austríaco, radicado no Reino Unido, criticasse o conservadorismo por sua hostilidade ao desenvolvimento do conhecimento do qual depende o progresso das civilizações, seu pensamento serviu de inspiração para políticos da Nova Direita. Por criticar posicionamentos coletivistas e de "vias do meio", em função de sua crença em um possível planejamento da economia e da ordem social e, também, por não ser possível definir objetivamente o que é justiça social. Em contrapartida, ele afirmava que apenas o mercado pode coordenar o pensamento prático, desenvolvendo e alocando recursos de forma eficiente, defendendo, portanto, um foco na produção e não na distribuição.

Embora fosse contrário ao "laissez-faire" universal de serviços sociais de bem-estar baseada no recolhimento de impostos, mas sim na forma de seguros sem monopólio estatal. As críticas a Hayek centramse em sua visão distorcida da social-democracia como um sistema diretivo de planejamento, enquanto, na verdade, se baseiam em técnicas de regulação que não restringem a liberdade substancialmente. Além disso, foi acusado de não perceber que a economia de mercado estimula a erosão de valores morais do qual depende sua própria existência (O’SULLIVAN, 2013).

Nos EUA, intelectuais da Nova Direita iniciaram a crítica ao consenso coletivista ao longo das décadas de 1950 e 1960, inspirados na insatisfação com o legado do New Deal ${ }^{7}$ de Franklin D. Roosevelt e do Great Society ${ }^{8}$ de Lyndon Johnson. Assim, o conservadorismo estadunidense esteve caracterizado por dois

\footnotetext{
${ }^{6}$ Laissez-faire do francês "deixar fazer", termo associado ao pensamento econômico liberal onde, segundo Jonh Hall (1996): "papel mais ativo para o estado (...) é o de um vigia noturno, protegendo uma estrutura dentro da qual as forças de mercado podem então operar de acordo com a sua própria lógica (p.258)".

${ }^{7}$ New Deal do inglês “novo acordo", segundo Herbert Stein (1996): “conjunto de medidas de política econômica tomadas nos Estados Unidos entre 1933 e 1940, sob a liderança do presidente Franklin Roosevelt, com a finalidade de produzir a recuperação da Grande Depressão (p.523)".

${ }^{8}$ Great Society do inglês "grande sociedade" em tradução livre foi o nome dado ao conjunto de programas voltados para a eliminação da pobreza e desigualdade social, promovido pelo presidente democrata Lyndon Johnson durante a década de 1960. (LACERDA, 2019).
} 
extremos: i) a defesa libertarianista ${ }^{9}$ de Estado mínimo, por pensadores como Robert Nozick, e, ii) a tentativa de aplicação do conservadorismo europeu aos EUA, como proposto por Russell Kirk. De um ponto de vista prático, destacam-se Milton Friedman - o mais proeminente nome da Escola de Chicago - que compartilhava a defesa do livre mercado com Hayek e James Buchanan que também criticava o planejamento estatal.

Paralelamente, o Neoconservadorismo (ou Novo Conservadorismo), surgiu como mais uma resposta ao Estado de Bem-Estar Social. Um exemplo pode ser encontrado na obra Irving Kristol (1920-2009). Ao apresentar uma forte marca cultural e moral, o jornalista e intelectual estadunidense acreditava que a civilização americana contemporânea estaria inclinada ao niilismo espiritual. Mais tarde isto também se refletiu na crença conservadora mais ampla de que o projeto de bemestar social do Great Society destruiu a responsabilidade individual dos cidadãos.

Para eles, as políticas de bem-estar falhavam na distinção entre o pobre "merecedor" e o pobre "indigno". Fundamentando-se na ideia de que a ação estatal para diminuição da pobreza e melhoria das oportunidades educacionais tinha gerado uma subclasse de famílias monoparentais constantemente dependente do Estado, os neoconservadores defendiam o retorno ao conceito tradicional de autonomia. O’Sullivan (2013) aponta que autores como Thomas Sowell (1981) e Charles Murray (1984), em suas críticas à cultura da dependência, tal como chamavam, previam um futuro. Para Murray, a democracia se tornaria uma democracia de custódia de bairros inteiros. Já Sowell via nas políticas de bem-estar destinadas a melhoraria de minorias étnicas um impacto contraproducente à sociedade como um todo.

A ascensão da Nova Direita neoconservadora nos EUA, tal como apresentada por O'Sullivan (2013) até aqui, impactou a política e a história não apenas daquele país naquele contexto, como ainda hoje influencia as dinâmicas de outros contextos políticos, como é o caso do Brasil. A seção seguinte procura explorar estas e outras particularidades do novo conservadorismo.

\footnotetext{
${ }^{9}$ O libertarismo de Robert Nozick, entre outros pensadores, tem origem no liberalismo clássico (escola de pensamento filosófico nascida no século XVII e predominante até a primeira metade do séc. XIX). A liberdade individual é vista, nessa perspectiva, como valor político básico, e a propriedade privada como a mais importante salvaguarda institucional. Defende-se um Estado mínimo, sustentado por impostos, e opõe-se a "justiça social" via redistribuição compulsória de renda (GISSURARSON, 1993).
} 


\subsection{Neoconservadorismo: dinâmicas, valores e influências da nova ideologia conservadora}

O movimento político neoconservador se fundamenta, segundo Marina Lacerda (2019), em um modo de pensamento que lhe é anterior. A intelectualidade neoconservadora ofereceu farta produção acadêmica em defesa do liberalismo econômico ${ }^{10}$ e do anticomunismo, a partir dos anos 1950. Já o movimento político se refere à articulação de diferentes agentes e valores em torno da eleição de Ronald Regan para presidente dos EUA nos anos 1980. Assim, a coalizão neoconservadora para ação política propriamente dita que se constrói a partir dos anos 1970. Ainda segundo a autora, sua conformação pode ser sintetizada da seguinte maneira: De um lado grandes representantes da elite econômica preocupados em reestabelecer seu poderio de classe, e do outro, uma considerável parcela da classe trabalhadora alinhada a um forte tradicionalismo moral. Sobre essa última, o pentecostalismo religioso teria grande influência.

Nesta pesquisa o neoconservadorismo será tratado daqui em diante como um movimento político. Seus valores e conceitos serão discutidos de maneira relacional, compondo, assim, o escopo analítico desta tese. Antes de avançar, contudo, é preciso qualificar melhor o argumento de que o neoconservadorismo é de fato um movimento de direita. A migração à direita dos intelectuais conservadores se deu ainda na década de 1960, quando, em resposta às lutas dos movimentos civis, feministas, estudantis e afins, o liberalismo ${ }^{11}$ nos EUA passou a incluir demandas da chamada "nova esquerda" através do já mencionado programa instituído pelo presidente democrata Lyndon Johnson, Great Society.

11 “O liberalismo em seu sentido genérico, se refere a moderna tradição ocidental de pensamento e comportamento, em contraste com as tradicionais formas de ordem encontradas na Ásia e na África. Dentro da efetiva política da Europa e da América, liberalismo refere-se a um conjunto específico de ideias, que, de tempos em tempos, destacam seus adeptos dos conservadores e dos socialistas. Exatamente o que constitui essa forma específica de liberalismo muda de uma geração para a seguinte. No século XIX, por exemplo, o liberalismo incorporou ideias como o livre comércio, a democracia e a autodeterminação nacional. Perto do final desse século, no entanto, surgiu um "novo liberalismo", enfatizando que o estado devia ser responsável por suprir as necessidades materiais dos pobres, de forma que estes pudessem exercer de maneira mais efetiva a liberdade de que deveriam desfrutar. Essa mediação rumo ao socialismo era evidentemente incompatível com o estado mínimo que muitos dos primeiros liberais haviam concebido como a única garantia de liberdade. Esse liberalismo clássico de meados do século XIX foi vigorosamente revivido durante os anos 70 e em geral encontrou abrigo em partidos que se auto classificavam como "conservadores (MINOGUE, 1993. p.424)". 
Ao refletir sobre as distinções possíveis entre direita e esquerda, Bobbio (1994) afirma que são as posturas adotadas pelos indivíduos organizados em sociedade em torno do ideal de igualdade que melhor permite tal diferenciação. Segundo o autor, a igualdade não é um conceito absoluto, mas sim relativo. Ao pensar em igualdade é preciso ter em mente três aspectos: os bens a serem repartidos, os sujeitos que os receberão e, por fim, os critérios utilizados para tanto. Num contexto de desigualdades sociais construídas, ou naturalmente herdadas, Bobbio aponta que a tendência das políticas de esquerda é o princípio do igualitarismo. Em síntese, políticas de orientação à esquerda buscariam tornar mais iguais ou desiguais, enquanto aquelas à direita tendem à acentuação e/ou naturalização das desigualdades.

Dessa forma, para Lacerda (2019), é possível caracterizar o neoconservadorismo como um movimento político de direita dada a sua natureza de oposição às políticas igualitárias coletivistas. O que diferencia a ideologia neoconservadora dos movimentos economicistas da direita, ainda segundo a autora, é a ênfase moral, sobretudo religiosa, nas questões sexuais e reprodutivas. É de grande importância destacar o papel desempenhado pela Direita Cristã na reação aos avanços feministas e homossexuais nos EUA, a defesa dos papéis tradicionais de gênero, da centralidade da família para a construção da sociedade e o espraiamento de suas ações sobre países da América Latina.

Formada por evangélicos com vínculos com a renovação carismática católica, a Direita Cristã investiu em estrutura organizacional, capilaridade social e capacidade de mover as massas religiosas em torno das bandeiras neoconservadoras. Embora minoria estatística, a difusão da ideia de universalidade dos valores cristãos garantiu ao movimento neoconservador a validação de maioria moral. Ao vincular religião e política, tal movimento pôde agir em duas frentes: i) perseguindo todo e qualquer indivíduo que ousasse transgredir os tradicionais papéis de gênero e ii) financiando o enfrentamento de ideologias (como a Teologia da Libertação) e governos mais progressistas em países como Argentina, Brasil, Chile, Peru e Uruguai na década de 1960 (LACERDA, 2019; LIMA; HYPOLITO, 2019).

As principais frentes de atuação do neoconservadorismo no Governo Ronald Reagan nos EUA foram: a defesa da família patriarcal, o neoliberalismo como política econômica, o punitivismo como garantia da ordem interna, o 
militarismo como garantia da ordem na política externa e, por último, a defesa do Estado de Israel como costura ideológica e religiosa simbólica na política internacional. Aparentemente não relacionados, Marina Lacerda sustenta a conexão existente em seu livro "O novo conservadorismo brasileiro" (2019). Nele, a autora traça um paralelo entre as dinâmicas do neoconservadorismo estadunidense surgido na década de 1970 e as atuais adaptações da ideologia neoconservadora na atualidade política brasileira. Essa literatura, conforme já mencionado na apresentação deste trabalho, compõe um importante referencial teórico nesta tese. Portanto, apresentarei a seguir os principais componentes de sua argumentação de maneira bastante sintética.

\title{
As frentes de atuação neoconservadora: conexões e implicações para o Brasil de hoje
}

A defesa da família patriarcal surge no neoconservadorismo como uma resposta às investidas feministas e dos movimentos LGBT - Lésbicas, Gays, Bissexuais, Transexuais e Transgênero. $\mathrm{O}$ argumento da depravação moral se somou à defesa religiosa de que a família é a instituição nuclear da sociedade. A falta de uma figura paterna forte levaria à delinquência juvenil, à gravidez na adolescência, à homossexualidade e à eterna dependência das políticas de bem-estar social. Para os conservadores, o fortalecimento da família tradicional patriarcal seria o melhor programa contra a pobreza ${ }^{12}$.

\begin{abstract}
Além de ameaçar a vida, o feminismo seria responsável pela disfunção percebidas na sociedade. (...) mina a família por se recusarem a aceitar as diferenças de gênero como naturais, rejeitando a autoridade do marido ou do pai, tentando mudar a divisão sexual do trabalho e propagando a ideia de que a uma mulher pode cumprir o papel tradicionalmente desempenhado por um homem (LACERDA, 2019, p. 40).
\end{abstract}

É interessante notar, contudo, que o papel da mulher nesse caso não deve ser visto como puramente submisso, dentro da lógica neoconservadora existe um

\footnotetext{
${ }^{12}$ No contexto da corrida eleitoral de 2018, o então candidato a vice-presidente do Brasil na chapa, posteriormente vencedora, de Jair Bolsonaro, Hamilton Mourão, fez uma afirmação semelhante. Para o General da reserva, famílias sem pais ou avôs são fábricas de desajustados: https://exame.com/brasil/mourao-diz-que-familia-sem-pai-ou-avo-e-fabrica-de-elementosdesajustados/.
} 
forte discurso que afirma as mães como responsáveis pela educação de seus filhos. É a mulher, a mãe, que deve lhes equipar com armas para modificar a sociedade em direção a valores condizentes com aqueles construídos no seio da família. Para isso, um lucrativo mercado de apostilas, livros, CDs e, principalmente, a internet, oferece uma rede de apoio material e de suporte psicológico que, ao mesmo tempo em que incute conhecimentos e valores alinhados ao cristianismo conservador, ajuda essas mulheres a desenvolver as habilidades necessárias para ensinar seus filhos e para lidar com o trabalho psicológico de uma educação em casa, o homeschooling (APPLE, 2010).

Sobre a defesa do neoliberalismo como política econômica, Harvey (2007) aponta à liberdade para empreender num Estado mínimo como principal característica. Isto significa, que ao Estado cabe o papel de defensor da integridade da propriedade e manutenção do aparato militar e policial. Lacerda (2019) destaca que o neoliberalismo e o conservadorismo têm divergências e não devem ser confundidos como sinônimos. O estímulo ao mercado versus a produção de uma ordem orientada para a repressão de desejos e a ideia de um futuro no qual as fronteiras serão apagadas pelo nexo monetário em contraposição ao fortalecimento do nacionalismo, são exemplos de princípios distintivos.

No entanto, ambos convergem em questões basilares, tais quais a recusa ao governo em relação ao fundamento de suas decisões, ambos atuam contra a liberdade política e a igualdade entre cidadãos, desvalorizando-os em função de critérios de mercado ou do uso do poder do Estado para fins morais. Por último e provavelmente mais importante: "O neoconservadorismo atua como uma resposta à erosão da moralidade no capitalismo, preenchendo esse vazio com valores morais rígidos, anticomunistas e opostos à distribuição de renda (LACERDA, 2019. p.51)”. Assim, o nacionalismo cultural, a defesa da família patriarcal, a retidão moral e a ênfase nos valores cristãos passaram a integrar o constructo político ideológico, para além da oposição ao intervencionismo estatal na economia (HARVEY, 2007).

Quanto ao idealismo punitivista, o contexto social de desmonte das políticas públicas de bem-estar é extremamente relevante. O Estado precisava ser mínimo nas relações econômicas e máximo para conter as consequências dessa escolha, nesse sentido, 
vítima, o medo, os custos com a segurança), mais do que nas raízes estruturais (econômicas e sociais) e político-ideológicas da questão. Atacam os criminosos em vez de atacarem a violência estrutural (a desigualdade social e a pobreza), razão da definição e seleção de determinados indivíduos como tais, simultaneamente à imunização de outros. (...) Em face da incapacidade de apresentar soluções aos problemas coletivos, as elites políticas, que já não podem prometer uma existência estável aos seus cidadãos, podem ao menos desviar o foco das incertezas individuais sobre como garantir os meios de vida para uma preocupação desatinada com a segurança pública (ARGUELLO, 2005, p. 2, 4).

A criminalidade passa a ser encarada pelo Estado como uma escolha individual, e não produto de um contexto social mais amplo, fruto de uma dinâmica política, econômica e cultural. $\mathrm{O}$ encarceramento em massa e o incremento da força policial surgem como substitutos às políticas de reabilitação e ressocialização, como no caso de Guerras às Drogas promovido por Ronald Reagan (LACERDA, 2019). Apoiando-se na crítica de David Harvey (2007) ao autoritarismo neoliberal, Lacerda aponta que o apoio da sociedade pode ser fomentado através do estímulo do medo de inimigos sejam eles reais ou imaginários. Em um contexto individualista em que os meios de solidariedade social foram dissolvidos, e a insegurança é uma constante, é preciso investir em mais lei e mais ordem para não chegar à desagregação do tecido social como um todo. Essa lógica é estendida à política externa, e movimenta o próximo eixo neoconservador: o militarismo anticomunista.

O militarismo neoconservador teve expressão no contexto da Guerra Fria. O combate à União Soviética (URSS) e a defesa dos ideais capitalistas esteve presente na política internacional norte americana durante esse período. A política externa até então baseada nos direitos humanos, nesse período investiu no combate ao terrorismo internacional, associado ao comunismo. Ao fim da década de 1980 e início dos anos 1990 o campo conservador se dividiu em duas posições: de um lado aqueles que defendiam a ênfase na política interna e na promoção da ordem (estes ficaram conhecidos como "paleoconservadores"), e do outro, aqueles defendiam a atuação dos EUA como líder do combate ao comunismo, permanecendo com a alcunha de neoconservadores propriamente ditos. Segundo Lacerda (2019, p. 45),

Essa cisão, ao lado do fim da URSS, implicou a estagnação ou mesmo a reversão do movimento neoconservador na década de 1990. Mas a controvérsia se diluiu e o neoconservadorismo 
ganhou novo fôlego depois do ataque às Torres Gêmeas em 11 de setembro de 2001. Então a direita religiosa e a secular se juntaram novamente para converter George Bush Jr. em promotor do resgate do papel da "América no mundo".

Lacerda aponta ainda que a política externa de George W. Bush pode ser entendida como uma releitura do reaganismo, no sentido da articulação entre a agressividade militar e o etos religioso. O inimigo não era mais o comunismo, mas sim o terrorismo islâmico. A demonização da religião não cristã fortaleceu o belicismo conservador, segundo a autora. Porém a Guerra ao Terror não foi o único item da política externa neoconservadora estadunidense.

Por fim, como última frente do neoconservadorismo figura a defesa de Israel como Estado. Apesar de ter sido uma fonte de antissemitismo ao longo da história, a aproximação entre cristãos evangélicos e sionistas se deu por afinidades religiosas e estratégicas. Na política externa, Israel foi um importante aliado dos EUA, na política interna a direita cristã que via no estabelecimento do Estado de Israel (compreendido como uma devolução ao povo judeu descrito na Bíblia) um sinal de que a Batalha Final estava chegando, e com ela a volta de Jesus Cristo. Assim,

...o apoio da direita cristã dos EUA para o governo israelense foi principalmente na frente da propaganda. (...) organizações carismáticas também forneceram valiosos serviços ao governo israelense, com transmissão de radiodifusão religiosa em apoio à causa, além de doações em dinheiro (LACERDA, 2019, p.44).

A defesa do sionismo por parte da direita cristã reflete uma aliança relevante do neoconservadorismo pois articula valores religiosos, questões econômicas e dinâmicas políticas internacionais. Ele ajuda a compreender que a religião, para além das implicações individuais que que figuram o plano do abstrato, como a alma e a salvação, possuem influência no plano real da existência humana. Podendo influenciar questões macroestruturais e políticas, sobretudo no que se refere às religiões hegemônicas de caráter expansionista, como é o cristianismo (ALVES, 2014).

Ao longo dos anos, o neoconservadorismo norte-americano manteve-se atuante. $\mathrm{O}$ ativismo contra o aborto e os direitos dos cidadãos LGBT ganhou destaque na década de 1990, mesmo durante a gestão democrata de Bill Clinton. A 
Guerra ao Terror empreendida pelo republicano George W. Bush acionou o militarismo próprio das bandeiras neoconservadoras, como anteriormente apresentado. Mas foi no Governo Barack Obama que a identidade neoconservadora voltou ganhou novos ares. Protestos contra programas sociais destinados às comunidades carentes foram alardeados como "esmola governamental para grupos indignos" (LACERDA, 2019, p.57). A formação do Tea Party dentro do Partido Republicano, seu avanço e posterior predominância nos rumos e ações do Partido Republicano, fortaleceu uma agenda de oposição aos direitos de minorias e a resistência - na forma de bloqueios e obstruções na Câmara dos Deputados e no Senado - a quaisquer propostas democratas. Esse cenário, aliado a seu grande poder econômico e popularidade, permitiu a Donald Trump romper com barreiras do sistema de escolha de candidatos à presidência e derrotar as lideranças tradicionais do Partido Republicano (LEVITSKY; ZIBLATT, 2018).

A gestão Trump promove um governo neoliberal, apoia a intervenção militar na Venezuela bolivariana (entendida como o novo centro de poder comunista a ser combatido) e apresenta posturas antifeministas. Em síntese, Donald Trump resume o neoconservadorismo moderno: privatista, neoliberal, conservador, militarista e de direita. Autores como Lacerda (2019) e Lima e Hypólito (2019) veem paralelos similares entre os processos históricos ocorridos nos EUA e a atualidade brasileira, em especial desde os protestos de 2013, acentuando-se com a contestação das eleições de 2014 pelo partido derrotado, com o impeachment de Dilma Rousseff em 2016 e culminando com a eleição de Jair Bolsonaro em 2018.

\subsection{Conservadorismo à brasileira: ressurgimentos e atualizações}

Consta na Constituição Federal de 1988 o reconhecimento dos direitos coletivos e demandas sociais que extrapolam o âmbito individual. A fim de assegurar a manutenção destes direitos, movimentos civis organizaram-se em torno de pautas políticas, sociais e culturalmente igualitárias. Nesse bojo, as questões identitárias de sujeitos sociais subalternizados, invisibilizados e discriminados socialmente ganharam força nas esferas públicas a partir dos anos 1990 (MIGUEL, 2016). Neste escopo encontram-se os movimentos sociais feministas, negros e das 
comunidades periféricas, gays, lésbicas, bissexuais, travestis e transexuais - LGBT (MACHADO, 2006).

Num movimento de resposta aos avanços obtidos por estes grupos, agentes antagônicos intensificaram as demandas de maior capacidade de moralização das relações sociais por parte do Estado (ALMEIDA, 2017). Como exemplo de ações que instigaram tal reação moralizadora temos a regulamentação e obrigatoriedade do Ensino da História e Cultura Afro-Brasileira na educação pública nacional - Lei 10.639/2003 (BRASIL, 2003) e o Decreto $\mathrm{N}^{\circ} 8.727 / 2006$ que institui o reconhecimento do nome social e da identidade de gênero de travestis e transexuais no âmbito da administração pública federal (BRASIL, 2006). Movidos por sentimentos de reação àquilo que entendem como decomposição do tecido social e de retomada da ordem e do progresso, grupos de natureza heterogênea (políticos de direita, líderes religiosos, personalidades influentes nas redes sociais, entre outros) passaram a exigir um Estado de orientação moral conservadora, economicamente neoliberal e um sistema de justiça com maior capacidade punitiva (LACERDA, 2019).

É importante observar que a onda conservadora não se origina ou se mantém confinada aos limites cronológicos e geográficos brasileiros. Para Burity (2018), as políticas internacionais europeias e norte americanas de reconhecimento das minorias e de ampliação do bem-estar social geraram nas elites desses locais diferentes níveis de ressentimentos e antagonismos. Ainda segundo o autor, após a globalização do capitalismo em sua versão neoliberal, a intensificação de conflitos entre potências econômicas por recursos, as crises econômicas e a crescente ameaça terrorista das últimas décadas levaram a simultâneos processos de auto imunização (construção de processos de limitação de direitos democráticos em nome do combate ao terror que vem de fora, do outro) e de internalização (entendimento de que o inimigo integra a sociedade e deve ser extirpado por repressão ou prevenção) também no cenário internacional.

Apesar de, no cenário brasileiro, os conservadores situarem-se no espectro político de direita (ou extrema-direita), conforme já discutido, conservadorismo e direitismo não devem ser confundidos, apesar de guardarem certa proximidade. Enquanto as direitas (já que há diferentes maneiras de fazer política seja à esquerda ou à direita) posicionam-se com maior ênfase frente às questões econômicas e securitárias do Estado, o neoconservadorismo não se resume a isso. Somados aos 
aspectos econômicos, bandeiras relacionadas ao papel da mulher na sociedade, a minimização dos direitos daqueles que não se encaixam nos papéis tradicionais de gênero e a radical defesa dos valores cristãos compõem o bojo político ideológico neoconservador (BURITY, 2018; LACERDA, 2019).

Ao olharmos para o cenário brasileiro podemos observar a presença do seguinte cenário: a atuação pró-família como núcleo da sociedade segue ganhando adeptos dentro e fora do parlamento; as reações contra a agenda LGBT e as discussões sobre a descriminalização do aborto tornam-se cada vez mais agressivas; a atuação parlamentar pela defesa do rigor criminal (a intensificação de clamores pela diminuição da maioridade penal, em maior grau, e pela instituição da pena de morte, em menor) e as demandas por privatização e diminuição do Estado encontram defensores em bancadas organizadas, como a chamada Bancada BBB 13 - Boi, Bala e Bíblia em referência aos interesses daqueles que a compõem: o agronegócio, o armamento civil e a bancada evangélica.

Tais aspectos apontam mais do que simples similaridades entre os movimentos neoconservadores internacionais, sobretudo norte-americanos, e a articulação de grupos que agitam a agenda neoconservadora nacional. Logo, o que há de "novo" no conservadorismo brasileiro? Segundo, Miguel (2016) e Lacerda (2019), o "novo" conservadorismo brasileiro na verdade se vale de atualizações e adaptações das ideias neoconservadoras estrangeiras. A gestão neoliberal lança mão de privatizações de serviços estatais após o deliberado sucateamento dos mesmos. A defesa da família ganha destaque com a atuação de uma bancada cristã (que se apresenta em sua maioria evangélica, mas conta com católicos conservadores para defender interesses comuns como a negação do aborto e dos direitos homoafetivos) e um chefe do executivo federal afinados com um discurso religioso moralizante e conservador. Por fim, o militarismo anticomunista, próprio do neoconservadorismo, transformou-se na luta contra as esquerdas e, principalmente, à Venezuela Bolivariana - compreendida como uma nova ameaça comunista que objetiva a dominação comunista da América Latina.

Assim, é possível afirmar que o Brasil vem passado por processos políticos e culturais que têm levado a retrocessos nos direitos adquiridos, sobretudo, após a

\footnotetext{
${ }^{13}$ A bancada evangélica é assim chamada por conter lideranças evangélicas em destaque, no entanto deve ser entendida como uma bancada cristã, já que é composta também por católicos conservadores (CUNHA, 2017).
} 
redemocratização. A "onda conservadora" que tomou o Brasil nos últimos tempos pode ser decomposta, segundo Ronaldo Almeida (2017), em quatro linhas de forças não totalmente alinhadas, mas articuladas o suficiente no combate a opositores comuns. A participação cristã, especialmente, evangélica acrescenta um componente a mais nessa mistura polarizada que se tornou a política brasileira. A seguir discutirei como essas linhas de força, a saber: moral, econômica, securitária e interacional, podem ajudar a pensar o cenário conservador vigente e suas implicações para a educação.

\subsection{1. $O$ (novo) conservadorismo em ação: As linhas de força em ação no cenário brasileiro}

O conservadorismo brasileiro pode ser entendido como um movimento interseccional e de múltiplos interesse que articula diferentes agentes em torno de pautas e inimigos comuns. Um emaranhado de processos sociais distintos, assimétricos e com diferentes temporalidades integram, na atual conjuntura, a dinâmica conservadora, segundo Ronaldo Almeida (2017). Ao refletir sobre a eleição do atual presidente brasileiro, o autodeclarado conservador, Jair Bolsonaro em 2018, Almeida (2019) aponta a maneira bem-sucedida de sua campanha em capturar a insatisfação popular com as políticas compensatórias. Algumas criadas, outras ampliadas durante os governos Lula e Dilma entre os anos de 2003 a 2016, como a lei de cotas raciais e o Bolsa Família, respectivamente, as políticas redistributivas ou de investimento nas camadas sociais mais vulneráveis gerou um profundo desagrado entre aqueles que se sentiam lesados e não contemplados por elas.

Em um aceno às camadas mais elitizadas, Bolsonaro delegou a gerência de sua política econômica a um economista liberal ${ }^{14}$ enquanto discursava sobre mérito e esforço individual, aproximando-se dos cristãos evangélicos adeptos da teologia

14 O "superministro" da economia, Paulo Guedes, coordena uma pasta oriunda da fusão de três ministérios: fazenda, planejamento e desenvolvimento. Tendo realizado seus estudos de pósgraduação na Universidade de Chicago, e, posteriormente, criado laços com o grupo Chicago Boys, Guedes busca implementar no Brasil um plano econômico pautado pelo Estado mínimo, tal qual no Chile ditatorial de Augusto Pinochet. Disponível em 15/06/2020: https://brasil.elpais.com/brasil/2018/10/30/politica/1540925012_110097.html 
da prosperidade ${ }^{15}$. Além da retórica anticomunista voltada para a ameaça encarnada pela Venezuela, prometeu em campanha o reconhecimento oficial de Jerusalém como capital de Israel, defendeu punições rigorosas aos infratores, o armamento populacional, utilizou versículo bíblico como bordão e, por fim, atrelou sua imagem à oposição contra a chamada ideologia de gênero (ALMEIDA, 2019). Todas as posturas anteriormente mencionadas enquadram-se na descrição apresentada por Lacerda (2019) do neoconservadorismo estadunidense.

O Bolsonarismo surge como uma resposta à dinâmica de instabilidade política e polarização social gestada no país após o ano de 2013. A crise econômica somada às dificuldades encontradas por Dilma Rousseff em sua gestão, culminando seu afastamento, abriu o espaço necessário para a consolidação de uma nova ordem política hegemônica. Burity (2019) aponta similaridades entre a derrota do projeto político desenvolvimentista adotado pelo PT e os afastamentos de outros líderes na América Latina: Manuel Zelaya em Honduras, 2009, e em 2012, Fernando Lugo no Paraguai. Nos três casos, houve o mesmo formato institucional: o impeachment. E, novamente, nos três casos os países sofreram uma reorientação à direita.

No caso do Brasil, contudo, houve uma especificidade que merece ser observada: o voto evangélico. Para Burity (2019, p.33), "uma das minorias beneficiadas pelas transformações trazidas pela democratização e agora inconciliadas com os rumos assumidos por esta última”, os evangélicos desembarcaram pragmaticamente de um barco sabidamente a pique.

O voto evangélico teve um grande destaque na eleição de Bolsonaro. Almeida (2019) apresenta a distribuição das intenções de votos faltando três dias para a eleição (Quadro 1), e a projeção do instituto de pesquisa de acordo com o número de eleitores brasileiros (Quadro 2).

\footnotetext{
${ }^{15}$ De modo geral a teologia da prosperidade difunde a crença neopentecostal de que os escolhidos de Deus devem obter vitórias para além do plano espiritual, ou seja, devem ser felizes, saudáveis e bem-sucedidos em seus empreendimentos terrenos. A prosperidade material somada às promessas de cura física e emocional, resolução de problemas familiares, afetivos e espirituais via intervenção divina propaladas em cultos presenciais ou eletrônicos atraem e convertem pessoas majoritariamente oriundas dos extratos sociais mais vulneráveis (MARIANO, 2004).
} 


\begin{tabular}{|c|c|c|c|c|c|c|c|c|}
\hline \multicolumn{2}{|c|}{ Quadro 1: Distribuição de intenções de votos válidos por religião } & & & Umbanda \\
Total\% & Católica & Evangélica & Espírita & $\begin{array}{c}\text { Judaica } \\
\text { Candomblé }\end{array}$ & $\begin{array}{c}\text { Sem } \\
\text { religião }\end{array}$ & Ateu \\
\hline Bolsonaro & 56 & 51 & 69 & 55 & 30 & 61 & 45 & 35 \\
\hline Haddad & 44 & 49 & 31 & 45 & 70 & 39 & 55 & 64 \\
\hline
\end{tabular}

Fonte: Pesquisa Datafolha, 25 out. 2018. In: Almeida (2019, p.37.). Destaques meus.

No primeiro quadro, levando em consideração a margem de erro de 2 pontos percentuais para mais ou para menos, é possível perceber que Bolsonaro teve êxito entre a maior parte dos grupos religiosos, com destaque para os evangélicos (69\%) e judeus (61\%). Fernando Haddad, candidato do PT, teve maior intenção de votos entre adeptos de matrizes religiosas africanas, Umbanda e Candomblé (70\%), e entre os sem religião (55\%) e ateus (64\%). Entre os católicos Bolsonaro (51\%) se sobressaiu, sem folga, em relação a Haddad (49\%).

Quadro 2: Distribuição de votos por tipo de religião, com correção de votos do DataFolha

\begin{tabular}{|c|c|c|c|}
\hline Religião & Votos de Bolsonaro & Votos de Haddad & Diferença \\
\hline Católica & 29.795 .232 & 29.630 .786 & 164.446 \\
\hline Evangélica & 21.595 .284 & 10.042 .504 & 11.552 .780 \\
\hline Afro-brasileiras & 31.2975 & 755.887 & -442.912 \\
\hline Espírita & 1.721 .363 & 1.457 .783 & 263.580 \\
\hline Outra religião & 709.410 & 345.549 & 363.862 \\
\hline Sem religião & 3.286 .239 & 4.157 .381 & -871.142 \\
\hline Ateu e agnóstico & 375.570 & 691.097 & -315.527 \\
\hline Total de votos & $\mathbf{5 7 . 7 9 6 . 0 7 4}$ & $\mathbf{4 7 . 0 8 0 . 9 8 7}$ & $\mathbf{1 0 . 7 1 5 . 0 8 7}$ \\
\hline
\end{tabular}

Fonte: Pesquisa Datafolha, 25 out. 2018. In: Almeida (2019, p.38). Destaques meus.

Quando levado em consideração o número de eleitores por tipo de religião território brasileiro, o Quadro 2 informa com clareza o equilíbrio nas intenções do eleitorado católico, adesão massiva dos evangélicos, e a desaprovação dos adeptos das religiões de matriz africana e daqueles sem nenhum credo e não crentes. Almeida (2019) aponta que o voto evangélico hegemônico em Bolsonaro configura uma aposta baseada em afinidade de valores, identidade e convicções reforçada pelo etos religioso movimentado durante a campanha. 
Atualmente, dados do IBGE apontam quão grande é o pertencimento religioso expresso pelo povo brasileiro. Segundo o censo, o Brasil é um país majoritariamente cristão - 64,6\% católico, 22,2\% evangélico (IBGE, 2010). Nesse sentido, Machado (2012) ressalta o significativo trânsito de fiéis em direção aos grupos de evangélicos nas últimas décadas, uma vez que os católicos somavam 83,3\% da população em 1991. Sobre tal ascensão, destaca-se o investimento de lideranças evangélicas nos meios de comunicação de massa e na política partidária durante o processo de redemocratização, período em que houve a facilitação de adesão às práticas religiosas conforme a opção de cada um (MARIANO, 2011; CUNHA et al, 2017).

Tal perspectiva ganha destaque no contexto atual da sociedade brasileira onde o avanço neoconservador se articula à reemergência religiosa proporcionada pelo maciço investimento midiático por parte de segmentos evangélicos neopentecostais ${ }^{16}$ sobretudo partir dos anos 2010. Ao conjugar estratégias mercadológicas e tecnológicas, o fenômeno neoconservador evangélico surge no bojo de uma conjuntura de fortalecimento de posturas conservadoras na esfera pública brasileira e encontram eco para além dos domínios religiosos (CUNHA, 2017). Em sua reflexão sobre as formas pelas quais a identidade subcultural evangélica influenciou o ativismo político dos coletivos evangélicos e quais as suas implicações para a arena pública, num período ainda anterior à eleição de Jair Bolsonaro, Ricardo Mariano (2016) já apontava o crescente engajamento deste grupo.

A identidade subcultural religiosa apontada por Mariano (2016) deriva da Teoria da Identidade Subcultural elaborada por Christian Smith em American evangelicalism: embattled and thriving ${ }^{17}$ (1998) para descrever a expansão de

\footnotetext{
${ }^{16}$ O neopentecostalismo, segundo Mariano (1999), nasceu a partir de um corte histórico institucional teológico e comportamental dentro do protestantismo pentecostal. O pentecostalismo brasileiro é dividido em ondas: $1^{\text {a }}$ onda - Pentecostal (1910-1950, abrange as igrejas mais antigas: Congregação Cristã no Brasil e Assembléia de Deus e historicamente abrigou as parcelas sociais mais e pouco escolarizadas e defendia um radical afastamento do mundo exterior à igreja. Ênfase no dom de línguas, na crença iminente de Cristo e na salvação paradisíaca), $2^{\mathrm{a}}$ onda Deuteropentecostal (Surgiu na década de 50 e investiu no evangelismo de massa, no dom da cura, menos ênfase no dom de línguas e difusão da mensagem via meios de comunicação de massa. Igrejas como a Deus é Amor, Casa da Benção e Brasil para Cristo a integram), e, por fim, a $3^{\mathrm{a}}$ onda - Neopentecostal (A partir da década de 1970. Traz a exacerbação da guerra espiritual contra o diabo, a pregação enfática na prosperidade material /sucesso econômico terreno, a flexibilização de costumes e estereótipos de santidade e a possibilidade de estruturação empresarial com fins lucrativos. Abrange a Igreja Universal, a Igreja Nova Vida e a Igreja Internacional da Graça, por exemplo).

${ }^{17}$ Em português: Evangelicalismo americano: tumultuado e próspero.
} 
grupos religiosos conservadores em ambientes de pluralismo cultural. Para Smith (apud MARIANO, 2016), um ambiente dotado de forte pluralismo religioso, diferenciação social e institucional, diversidade religiosa e racionalização, tal qual o ocidente moderno, não somente deixaram de fragilizar as religiões, como era de se esperar, como também criaram condições propícias ao fortalecimento de grupos que engajam a militância religiosa no enfrentamento inimigo. Em síntese, a identidade subcultural religiosa é um entendimento religioso que se assegura através do engajamento, da coesão e do compromisso de seus membros no combate às ameaças à sua religião. Tais ameaças abarcam todo tipo de afronta aos seus valores, sua liberdade e sua moral.

Ainda segundo Mariano (2016), a "desprivatização" pentecostal, entendida como o abandono definitivo da atuação religiosa restrita à esfera privada e a adesão do ativismo político, ocorrida nos anos 80 , favoreceu a inserção política do segmento evangélico em todo país. Atualmente, seu poder de influência não pode ser minimizado dada a ferocidade que elege e ataca seus opositores. Em suas palavras,

$\mathrm{O}$ antagonismo de grupos evangélicos conservadores à ampliação dos direitos civis de minorias sexuais e a aspectos da cultura secular representa, em boa medida, reação defensiva a um sem-número de mudanças socioculturais, legais e políticas. Reação que, de um lado, pretende proteger a família tradicional, a moralidade cristã, a liberdade religiosa e de expressão. De outro, fundamenta-se na disposição para tentar restaurar uma certa ordem moral e social tradicional, que creem estar sendo destruída pelo ativismo político-ideológico de seus adversários e pela disseminação desenfreada da imoralidade e da corrupção dos costumes ..." (p. 723).

A fim de caracterizar aqueles que aqui chamo de evangélicos acredito ser necessário esclarecer que este é um termo em disputa entre aqueles que assim se autodeclaram. Muitos preferem ser chamados somente de "cristãos" dada a carga negativa associada ao termo em determinados contextos (ALMEIDA, 2017). Os evangélicos, também chamados de protestantes, compõem o terceiro grande ramo do cristianismo, juntamente à Igreja Católica e à Igreja Ortodoxa, e não devem ser entendidos como uma massa homogênea. Tradicionalmente divididos em históricos ${ }^{18}$ e pentecostais ${ }^{19}$, tendo este último gerado um novo subtipo religioso,

\footnotetext{
${ }^{18}$ São consideradas protestantes históricos: metodistas, batistas e luteranos, por exemplo.

${ }^{19}$ Igrejas como a Assembleia de Deus e a Congregação Cristã são exemplos de igrejas pentecostais.
} 
os neopentecostais ${ }^{20}$, apresentam diferenças na maneira como se apropriam dos evangelhos de cristo em que se baseiam (CUNHA et al, 2017).

Entretanto, a despeito das peculiaridades pertencentes aos distintos grupos de evangélicos brasileiros, é possível observar certas recorrências que ajudam a compor um quadro identitário comum ao segmento: i) leitura literal dos textos sagrados, ii) ênfase na piedade pessoal na busca de salvação da alma e iii) postura de negação das manifestações culturais do país, bem como notadamente anticatólicas e antiecumênicas (CUNHA, 2017). A leitura do Quadro 2 permite a percepção de que $2 / 3$ daqueles que se autodeclaram evangélicos, viram no conservadorismo bolsonarista algo que lhes representava e optaram por ele em detrimento à continuidade dos projetos políticos petistas.

Almeida (2017) afirma que a diversidade compreendida ao termo “evangélico" não deve ser compreendida apenas em termos conservadores. Muitos preferem agir mais da esfera da sociedade civil, através de ONGs, movimentos e associações. Outros, segundo o autor, fogem do mainstream conservador e adotam um discurso mais progressista. Almeida afirma que nem todos os evangélicos aderem a pauta conservadora, bem como o conservadorismo religioso não se restringe aos evangélicos. Católicos e membros de outras religiões se juntam a não religiosos no protagonismo da "onda" conservadora brasileira. Tal onda, na verdade, seria composta por um emaranhado de vários jogadores em diferentes tabuleiros. Os processos sociais que a compõe são dinâmicos e as alianças são relacionais. No entanto, ainda segundo o autor, não é possível ignorar o protagonismo de segmentos evangélicos pentecostais e neopentecostais nesse processo. Neste trabalho endossamos este entendimento: os cristãos evangélicos não constituem um todo homogêneo, no entanto, parcelas significativas desse grupo social integra o movimento conservador vigente.

As linhas de força que compõe a onda conservadora, discutidas por Almeida (2017; 2019) são quatro: moral, econômica, securitária e interacional. Cada uma será apresentada na seção seguinte. Acredito que elas ajudam a tornar mais nítido os agentes e agendas em ação na onda conservadora brasileira.

\footnotetext{
${ }^{20}$ A Igreja Universal, bem como as igrejas Internacional da Graça de Deus e Renascer, são exemplos de igrejas neopentecostais.
} 


\subsubsection{A onda quebrada do conservadorismo brasileiro: linhas de força, agendas e agentes}

O conservadorismo, conforme exposto até aqui, não é um conceito monolítico. Suas configurações mudaram ao longo da história. Diferentes agentes, em diferentes contextos, defenderam suas pautas e suas concepções de sociedade ideal. A onda conservadora brasileira atua em direções distintas e, portanto, pode ser entendida como uma "onda quebrada". Seus atores, ideologias e objetivos formam um movimento heterogêneo, múltiplo em interesses, ora se aproximando, ora se distanciando. Mas sempre buscando criar resistência e reação aos inimigos comuns (ALMEIDA, 2017).

São quatro as linhas de força destacadas por Almeida (2017): i) moral, ii) econômica, iii) securitária e iv) interacional. Cada uma atua em uma frente e movimenta valores próprios. Contudo, se articulam entre si dentro do guarda-chuva conservador vigente (Figura 1).

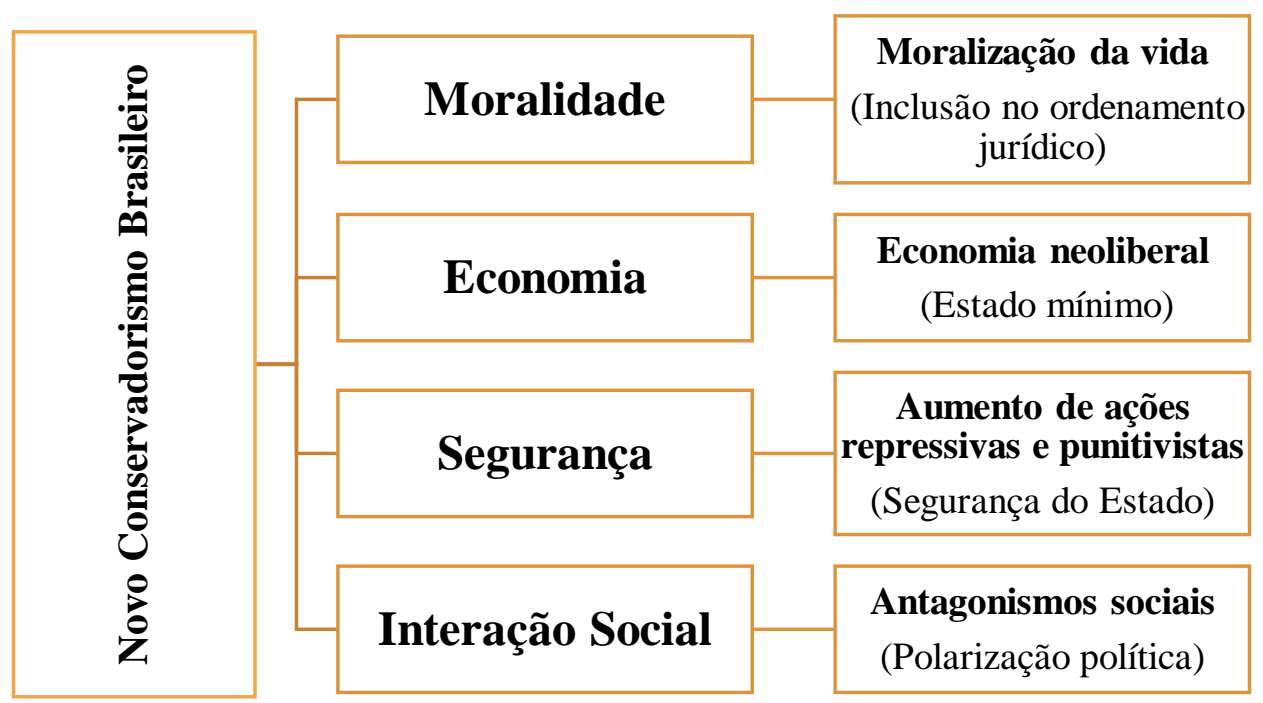

Figura 1: As linhas de força do novo conservadorismo brasileiro segundo Ronaldo Almeida (2017). Fonte: A autora.

Enquanto a pauta moral encontra forte adesão religiosa cristã, a questão econômica se articula com a teologia da prosperidade com foco sobre o sucesso individual e defesa do Estado mínimo. As demandas por repressão são exacerbadas em bordões tais como "bandido bom é bandido morto", apesar de ir de encontro ao princípio de amor ao próximo do cristianismo. Estes são exemplos de como as 
linhas podem se aproximar ou distanciar de acordo com o contexto e os objetivos em jogo.

\subsubsection{A maioria moral cristã}

No âmbito da moralidade pública, as religiões cristãs exercem o principal papel de defesa da família e da reprodução da vida. Nesse segmento, católicos e evangélicos convergem para entendimentos favoráveis à contenção dos avanços do secularismo nos comportamentos e valores (ALMEIDA, 2017). Questões como aborto, pesquisas com células tronco embrionárias, casamento homoafetivo, adoção por casais homossexuais, avanços de pautas identitárias e políticas de distribuição de renda, entre outras, agem como catalizadores da linha de força de moral e seus agentes.

Assim, setores do catolicismo tradicional e carismático em conjunto com, a cada vez mais intensa, participação dos evangélicos pentecostais, culpam o avanço do secularismo pela degeneração do tecido social. Se, entre idas e vindas, o Brasil experienciou alguns avanços nas conquistas de direitos (civis, sociais, sexuais e reprodutivos), o discurso conservador busca através da moralização controlar corpos, afetos, vínculos e comportamentos. Tal busca não se limita à dimensão retórica tradicionalista, mas sim à inserção no ordenamento legal brasileiro (ALMEIDA, 2017).

Ainda, segundo Almeida (2017), a pauta moral tem agido de maneira mais contundente no Poder Legislativo. Algo relativamente novo, dada a entrada dos evangélicos na política institucional remeter aos 1980. Em seus primórdios, o objetivo da "política evangélica" se centrava na captação de recursos para as redes religiosas (concessão de meios comunicativos e isenção de impostos) do que propriamente uma ação moralizante regulatória e prescritiva. A mudança de condição pode ser observada após os anos 2013, quando, ainda no Governo Dilma, após negociações políticas, a presidência da Comissão de Direitos Humanos e Cidadania da Câmara dos Deputados (CDHC) passou aos cuidados do Partido Social Cristão (PSC).

Sabe-se que, enquanto a CDHC esteve associada historicamente às questões sociais, indígenas, agrárias, imigratórias e voltadas para a superação da violência na cidade e no campo, o PSC, por sua vez, surgiu em 1990 e assume-se como 
partido conservador cristão. Em suas diretrizes ${ }^{21}$, constam a defesa da vida desde a concepção (contra a legalização do aborto), a defesa da redução da maioridade penal (a partir de 16), e a defesa do livre mercado (menos intervenção estatal na economia). O PSC indicou para presidente da CDHC o pastor Marco Feliciano, até então pouco conhecido, mas abertamente adepto da ideia de "salvação da família". Em entrevista, o deputado federal e ex-presidente da Comissão de Direitos Humanos afirmou

Eles [a comunidade LGBT] querem impor o seu estilo de vida e a sua condição sobre mim. E eles lutam contra a minha liberdade de pensamento e de expressão. Eles lutam pela liberdade sexual deles. Só que antes da liberdade sexual deles, que é secundária, tem que ser permitida a minha liberdade intelectual. A minha liberdade de expressão. Eu posso pensar. Se tirarem o meu poder de pensar, eu não vivo. Eu vegeto e morro. Fonte: $\mathrm{UOL}^{22}$

"Antes pedintes, agora negociadores", Cunha et al (2017) recuperam um trecho da carta aos evangélicos produzida pelo Bispo Robson Rodovalho, Líder da igreja neopentecostal Sara Nossa Terra, em 2014, quando este afirma que as lideranças evangélicas ganharam respeito e força sobre a ação dos candidatos que apoiam, passando, então, da condição de pedintes para aquela em que exige ser ouvido e possui poder de negociação.

O número de evangélicos cresce a cada dia. Segundo o censo de 2010 , éramos $22,2 \%$ da população naquele ano. Se projetarmos esse percentual para o universo do eleitorado existente em julho de 2013, o dado mais atualizado disponível, estamos falando em cerca de 31 milhões de votos entre 141 milhões de votantes. Com esse capital, mesmo dispondo de um nome natural, mas não obrigatório, como opção de voto para o segmento, mais do que nunca estamos dispostos a debater, a participar do processo eleitoral. Só que agora reconhecidos pela efetiva representação que temos na sociedade, respeitados como cidadãos, não como número de votos (Trecho da carta aos evangélicos produzida pelo Bispo Robson Rodovalho. In: CUNHA et al, 2017, p. 47).

É interessante observar que, apesar da recente ascensão do novo conservadorismo brasileiro, religião e política estão profundamente relacionadas desde a chegada dos colonizadores portugueses às terras brasileiras. Para pensar a influência atual do conservadorismo religioso, exercido através da linha de força

${ }^{21}$ Os valores e diretrizes que inspiram o PSC podem ser encontrados no endereço eletrônico do partido. Disponível em: https://psc.org.br/missao-valores/. Acesso em: 21/06/2020.

22 Disponível em: https://noticias.uol.com.br/politica/ultimas-noticias/2013/04/02/leia-atranscricao-da-entrevista-de-marco-feliciano-a-folha-e-ao-uol.htm,. Acesso em 11/10/2020. 
moral, sobre os rumos da política nacional é preciso lançar mão de dois conceitos: secularização e laicidade.

Se na Idade Média (sécs. IV-XV), a Igreja detinha o monopólio sobre os campos da educação e da cultura na Europa, o que se segue no período moderno europeu é a busca pela ruptura com as tradições cimentadas culturalmente, trazendo consigo dois valores fundamentais: a ideia de progresso e a valorização da subjetividade. Combinados, tais valores impulsionaram o rompimento com as tradições que organizavam a vida social até então conhecida. Aqui se insere um importante conceito, a secularização. A secularização é um termo que exige cautela e clareza, dada a gama de significados e apropriações existentes. Inspirado na palavra latina medieval saeculum, o termo poderia estar relacionado tanto à passagem do tempo, quanto à separação entre uma realidade sagrada e outra profana, passando ainda pela ideia de ação legal, onde uma pessoa religiosa deixa o claustro para viver no mundo secular (profano). Um outro sentido associado à secularização se refere ao processo histórico real, quando houve expropriação de propriedades rurais e riquezas da Igreja e apropriação em massa, sobretudo pelo Estado, após a Reforma Protestante e os conflitos religiosos decorrentes desta (CASANOVA, 1994).

A ideia de secularização, desde então, viu-se vinculada à transferência de funções, significados, pessoas, propriedades e afins, da esfera religiosa para as esferas seculares, seja pela força ou negociação. Mariano (2011) chama atenção para o fato a secularização poder assumir sentidos de paradigma, teoria, conceito e, mesmo fenômeno histórico, e que estes correlatos se associam à noção de diminuição da presença e influência das organizações, crenças e práticas religiosas sobre fenômenos socioculturais e instituições jurídicas e políticas. Assim sendo, é preciso fazer aqui uma distinção entre a secularização enquanto conceito ou teoria sociológica, do processo de secularização historicamente aceito.

Para fins de entendimento, a secularização como teoria sociológica, pode ser entendida como o processo pelo qual as religiões entrariam em declínio - tanto no espaço público em geral, quanto nas consciências individuais - à medida que as sociedades fossem se modernizando. Assim, a teoria da secularização teve por base os trabalhos de Max Weber que apontava a racionalização como principal fator de diferenciação das esferas sociais modernas. Analisada de um ponto vista político e estrutural, a secularização abarcaria não só a separação definitiva entre Estado e 
Igreja, como também tomaria tanto as muitas terras desta última e sua função educacional das mãos eclesiásticas. Quando relacionada às questões culturais, a secularização retiraria os temas religiosos do centro das artes, discussões filosóficas e tratados literários, favorecendo grandemente a ascensão como uma perspectiva para leitura do mundo autônoma e, portanto, secular. Desse modo, esperava-se que com a passagem do tempo a religião tivesse sua influência diminuída também sobre as consciências dos sujeitos, sendo então confinadas às esferas privados ou, em última análise, desaparecendo (BERGER, 1985).

Já para José Casanova (1994), a secularização pode ser abordada a partir de duas abordagens: um fenômeno mais amplo de diferenciação de esferas sociais ocorrido no ocidente e em boa parte do oriente, e um outro esperado, mas não ocorrido, a privatização religiosa. Para o primeiro estabelece quatro fatores históricos que culminaram na crescente tendência de encolhimento da presença e influência religiosa nas diferentes esferas públicas: Reforma Protestante, Capitalismo Moderno e Formação de Estados Modernos e a Racionalidade Científica.

i) Sobre à Reforma Protestante, é possível perceber, segundo o autor, o quanto a destruição da hegemonia cristã ocidental permitiu não apenas o surgimento de novos ritos religiosos, como também influenciou a criação de uma nova superestrutura religiosa alinhada à nova ordem econômica emergente (a burguesia) em detrimento das monarquias cristãs até então estabelecidas.

ii) A formação de estados modernos, por sua vez, inverteu a lógica de submissão anteriormente existente e, em sua primeira fase absolutista, tornou o altar (Igreja) submisso ao trono (Estado).

iii) O capitalismo, então, muda radicalmente a economia medieval (baseada na concentração de riquezas nas mãos do clero e dos nobres feudais) ao estabelecer o lucro e a acumulação de capital como objetivo das trocas econômicas.

iv) A racionalidade científica, rejeitava um entendimento do real que se legitimasse pela sua antiguidade ou por desígnios divinos. Os Iluministas abriram, assim, o caminho para o florescimento da racionalidade moderna. Juntos, segundo o autor, esses quatro processos contribuíram com suas dinâmicas características para a modernização social e, por consequência, 
favorecimento do processo de secularização, entendido como processo de diferenciação das esferas sociais e suas funções. Já em relação à segunda abordagem, a privatização religiosa prevista por muitos estudiosos, não se concretizou. Ao contrário, para o autor, a ascensão de movimentos religiosos em diferentes lugares do mundo e a exigência destes em ter voz ativa nas esferas públicas caracterizaria uma "desprivatização" da religião.

Entre a teoria e a realidade, Geertz (2001), por sua vez, observa que, ao contrário do que os autores da Teoria da Secularização apostavam, não somente a religião não desapareceu, como também não se encontra apenas no domínio da experiência religiosa individual e subjetiva, mas sim (re)surge como ator social que exige atenção. Ao olharmos para a conjuntura global (ascensão de conflitos de cunho religioso em diferentes partes do mundo), de maneira geral, e para a conjuntura nacional (avanço de pautas conservadoras no campo político), em específico, tal constatação fica bastante nítida. Ao afirmar que o pertencimento a determinado credo religioso exerce sobre a vida daqueles que o professam grande influência sobre sua visão de mundo, Geertz (1989) chama atenção para a relevância deste fenômeno para compreensão das dinâmicas sociais relacionadas ao lugar da religião nas esferas públicas. Nas palavras do autor, tal componente se configura como um poderoso sistema de símbolos e significados que atua no estabelecimento de duradouras disposições

e motivações nos homens através da formulação de conceitos de uma ordem de existência geral e vestindo essas concepções com tal aura de fatualidade que as disposições e motivações parecem singularmente realistas (GEERTZ, 1989, p.67).

Ainda segundo o antropólogo, o fenômeno religioso deve ser entendido como parte fundamental da cultura humana e que deve ser analisado em suas múltiplas dimensões: "Sentido", "Identidade" e "Poder". Tais dimensões se interpenetram e geram implicações reais sobre as dinâmicas sociais. Em outras palavras, alinhado ao modo como o real é percebido, uma busca identitária individual e coletiva - se faz presente, algo que permite engajamento social e capacidade de ação. Ao oferecer orientações sólidas àqueles que vivenciam contextos sociais de incerteza e de crises institucionais, as religiões ganham força de significação da existência humana e atuam como elementos de forte relevância na construção identitária dos grupos de fiéis associados. Destaca-se, também, o 
potencial religioso de influência sobre disputas políticas e governamentais, dada a capacidade de interferência de esforços coletivos sustentados por princípios religiosos sobre as esferas públicas. O pertencimento religioso, então, influencia como as pessoas entendem não apenas o mundo a sua volta, como a si mesmo e seu papel nele (GEERTZ, 2001).

Mesmo Peter Berger, outrora um defensor da Teoria da Secularização, ao revisitar sua obra aponta o fato de que não só a religião não desapareceu de cena, como em muitos lugares tornou-se uma força ainda mais expressiva do que no passado. Para ele, num contexto social de incertezas, as religiões encontram cada vez mais terreno fértil para sua existência e expansão. Em seu entendimento, apesar da influência inegável nas mudanças sociais e políticas nos séculos subsequentes à Renascença, não é possível afirmar que a secularização tenha tido êxito absoluto (BERGER, 2001). Ainda segundo Berger, é possível, entretanto, separar a secularização em dois tipos não necessariamente vinculados: secularização objetiva e secularização subjetiva. Enquanto a primeira se refere à saída da religião do espaço público (diminuição de sua força econômica e política), a segunda relaciona-se ao enfraquecimento da religião enquanto crença. Por não ocorrem de maneira simultânea e/ou conjunta, o autor afirma que uma instância pode ser mais bem-sucedida que outra num mesmo espaço geográfico. Dois exemplos diferentes, mas que ilustram tal afirmativa são os Estados Unidos e o Reino Unido. Se nos EUA a secularização objetiva ganha destaque, uma vez que Estado e Igreja possuem delimitações claras de sua área de atuação, mas o povo possui forte pertença religiosa. No Reino Unido, por sua vez, ganha aquela que se caracteriza pela diminuição da fé dos indivíduos, mesmo que a monarca regente seja também chefe da Igreja Anglicana.

Tendo em vista tais constatações, algumas questões sobre a pertinência e potência deste conceito para investigação proposta podem surgir. Entretanto, opto por utilizá-lo por entender, assim como Casanova (1994), que o processo social de secularização de fato ocorreu, o que não se concretizou foi a definitiva privatização e marginalização da fé. Tal entendimento encontra suporte em outro importante conceito a ser discutido, a laicidade. Fortemente relacionada à secularização, a laicidade pode ser entendida como um doutrina de não interferência entre instâncias religiosas e o Estado 
Enquanto a secularização pode ser entendida como um panorama mais amplo de diferenciação estrutural e funcional das esferas públicas, a laicidade será utilizada nesse trabalho com o sentido de valor vinculado aos direitos fundamentais de liberdade religiosa e igualdade. Em relação ao primeiro, garante institucionalmente a individualidade religiosa. Quanto ao segundo, baseia-se no principio de respeito e mesmo tratamento legal àqueles que professam qualquer qualidade de credo religioso, bem como àqueles que não possuem nenhuma filiação religiosa (SARMENTO, 2007). Tal entendimento de laicidade implica compreendê-la como um instrumento que operacionaliza juridicamente a separação entre Estado e religião. Nesse sentido, tanto são asseguradas à liberdade de culto quanto a soberania estatal. É importante ressaltar que, embora, a noção de laicidade refira-se históricamente à emancipação do Estado da autoridade religiosa, no Brasil a esperada neutralidade estatal em relação às religiões nunca se efetivou. Assim sendo, é possível dizer que vivemos num país oficialmente laico desde o estabelecimento da República, mas não totalmente secular (MARIANO, 2011). Mesmo que oficialmente o Estado brasileiro e as instâncias religiosas possuam dimensões e níveis separados de atuação, na prática, ao longo da História, “a Igreja Católica, mais do que qualquer outro grupo religioso, se beneficiou dos auxílios financeiros, das isenções de impostos e das parcerias com agências governamentais (MACHADO, 2012, p. 31)".

A chamada laicidade à brasileira, segundo Mariano (2011), tem origens na própria construção identitária brasileira historicamente construída. O catolicismo português conviveu com os cultos africanos e rituais indígenas, dando origem a um tipo de catolicismo místico, popular, marca do sincretismo religioso brasileiro. Entretanto, o status de religião oficial coube apenas à Igreja Católica. Cabe destacar, conforme Brandão (1988), que aos cultos de matriz africana e rituais indígenas era atribuído o sentido de "crendice", ocupando um lugar hierárquico menor e, portanto, passível de serem criminalizados e reprimidos.

A separação oficial decorrente da Proclamação da República não se traduziu na prática como um rompimento entre Estado e Igreja, tal qual se viu na Europa iluminista e anticlerical (CASANOVA, 1994). No Brasil, as relações estabelecidas entre a Igreja Católica e a República eram tão naturalizadas que os chamados valores cristãos eram considerados parte integrante da identidade cultural brasileira. Logo, a laicidade como um princípio nuclear a ser defendido e preservado nunca 
foi uma realidade estruturante da sociedade brasileira. No que se refere à perseguição às chamadas "falsas religiões", religiões de matriz afro-brasileira e espíritas, Mariano (2011) chama atenção para o fato de que esta estendeu-se oficialmente até o final dos anos 1950, graças à atuação de instituições como o Secretariado Nacional para a Defesa da Fé e da Moralidade (inaugurado em 1953) ${ }^{23}$.

Ao adotar a pauta dos costumes morais do conservadorismo religioso, e fazer dela seu carro chefe, Jair Bolsonaro marca, segundo Almeida (2019), o claro posicionamento de que não pautará sua gestão a partir de uma lógica laica. Tal adesão mostra que o atual presidente não intenciona admitir a diversidade de religiões nos espaços públicos. Assim, o alinhamento bolsonarista aos vetores mais conservadores do evangelismo brasileiro vai ao encontro dos ideais dessa porção majoritária do pluralismo cristão: o entendimento da democracia a serviço da maioria em detrimento da proteção às minorias e às diferenças. Em seu discurso pós eleição é possível ratificar a postura apresentada por Bolsonaro em toda a sua campanha eleitoral: o combate à "ideologia de gênero", a "ameaça à família tradicional", a "criminalização da esquerda e do comunismo".

Nesse contexto, é possível observar a construção de uma moralidade religiosa pública que pretende influenciar não apenas o comportamento dos indivíduos, mas também o ordenamento jurídico do país. Contudo, o novo conservadorismo brasileiro não se restringe à pauta moral. A seguir, discutirei a segunda linha de força apresentada por Almeida (2017) como componente da onda conservadora.

\subsubsection{Economia, meritocracia e empreendedorismo}

Na linha de força econômica ocorre o rechaço às políticas públicas e sociais redistributivas. Vistas como celebração ao comodismo e clientelismo político, defende-se, em contrapartida, a lógica meritocrática. Nesse contexto, a única ascensão social celebrada como digna é aquela que não depende de intervenção estatal e vale-se dos esforços individuais realizados. Em seu nível macro, a agenda defendida é a liberal de livre mercado e Estado mínimo. Num diálogo com a linha

\footnotetext{
${ }^{23}$ Tal órgão, criado durante o governo Vargas em sua fase democrática, tinha como objetivo coibir a expansão amoral e imoral, e as falsas ideias, pregadas pelas falsas religiões.
} 
de força moral, reforça valores neopentecostais de prosperidade e sua incentiva sua disposição ao empreendedorismo (ALMEIDA, 2017).

A ética econômica que compõe esta linha de força conservadora se subdivide, então, em duas frentes que se complementam: i. macroestrutural e ii. individual. Enquanto na primeira os valores e argumentos giram em torno da diminuição do Estado, na segunda ocorre a celebração do esforço próprio e da disposição empreendedora. Para discutir estes aspectos, trago dois conceitos: o neoliberalismo e a teologia da prosperidade. É interessante observar que, mesmo operando em dimensões distintas, estas dinâmicas se complementam e legitimam num contexto conservador maior.

Para pensar o contexto social neoliberal que essa frente advoga é preciso fazer algumas distinções preliminares. O neoliberalismo, entendido como uma retomada do liberalismo clássico, difere tanto do libertarianismo econômico social, quanto do "liberalismo encapsulado". Ou seja, o neoliberalismo se distância tanto do libertarianismo (defensor da mínima intervenção estatal na economia e na esfera moral), quanto do liberalismo que se associa à social-democracia (defensor do Estado de bem-estar através do aumento de gastos públicos com programas sociais e maior regulação do mercado). O neoliberalismo estabelece sua retórica a partir da liberdade individual, da eficiência e do lucro em um contexto de livre mercado. O vazio deixado pela dissolução das políticas de bem-estar coletivistas é preenchido pela lógica neoconservadora fortemente baseada em valores morais (HARVEY, 2007; LACERDA, 2019).

Sobre a atuação parlamentar neoconservadora na Câmara dos Deputados, Lacerda (2019) aponta que, embora os parlamentares com pouca frequência se expressem textualmente favoráveis a pautas claramente neoliberais (a favor do desmantelamento de políticas de bem-estar social, por exemplo), suas votações favoráveis em questões como a mudança da participação da Petrobras na exploração do pré-sal e do teto dos gastos públicos deixam clara essa orientação ideológica. Ambas as pautas foram levadas à votação ainda durante a gestão de Michel Temer, em 2016. Enquanto a primeira implica na desnacionalização de recursos naturais em favor do manejo estrangeiro e, portanto, na soberania nacional ${ }^{24}$, a segunda

\footnotetext{
${ }^{24}$ Wendy Brown, professora estadunidense da Universidade da Califórnia, em Berkeley, afirma que ao "liberar o capital para caçar mão de obra barata, recursos e paraísos fiscais em todo o mundo
} 
investe numa perspectiva de Estado "menos inchado", e congela por vinte anos os gastos públicos.

Isso se modifica, contudo, quando se trata da reforma trabalhista, também aprovada no governo Temer, a qual teve menor adesão desses parlamentares. Lacerda (2019) destaca que essa é uma pauta de efeito mais imediatamente perceptível para o eleitorado. Tendo em vista que boa parte da base de apoio dos referidos congressistas é de evangélicos pentecostais de camadas populares, as mudanças previstas na reforma reduziriam diretamente os seus direitos. A explicação para essa dinâmica, é sintetizada da seguinte forma pela autora:

Essa tensão entre o evangelismo residir sobretudo em grupos sociais empobrecidos - carentes de proteção estatal - mas, ao mesmo tempo, pregar soluções baseadas na livre competição pode explicar o apoio decrescente às votações estudadas acima: se os parlamentares evangélicos têm um eleitorado centrado nas classes sociais mais pobres, tendem a ter dificuldade em apoiar medidas que reduzem diretamente os direitos desses grupos, embora possam aderir a outras medidas de cunho neoliberal, o que é condizente com a própria doutrina religiosa (LACERDA, 2019, p.178).

Se num nível macro a defesa da linha econômica se centra na diminuição do Estado e na instituição do livre mercado, num nível individual a aposta é a Teologia da Prosperidade neopentecostal. $\mathrm{O}$ incentivo à aquisição de bens materiais e ascensão financeira via empreendedorismo objetiva, segundo Almeida (2017), preparar o fiel para estabilidade econômica e enfrentamento das dificuldades sem auxílio governamental. Segundo o autor, a ética adotada não é a ética protestante clássica que advoga a obtenção do sucesso econômico via conduta metódica no trabalho secular estimulada por uma doutrina religiosa. Na ética da Teologia da Prosperidade o sucesso não está na disciplina e na dedicação, mas sim na disposição empreendedora que objetiva tornar patrão nas relações de trabalho àqueles que Deus abençoa.

Estabilizada no meio evangélico e para além dele, a ideia de sintonia entre consumo e prosperidade foi propagandeada inclusive nos governos de centroesquerda do PT. Em uma recapitulação da história recente, Almeida (2019) aponta que a permanência da Igreja Universal do Reino de Deus, via Partido Republicano

inevitavelmente gerou padrões de vida mais baixos para as populações da classe trabalhadora e da classe média no Norte global; exploração contínua e limitações à soberania, acompanhadas por um desenvolvimento (desigual) no Sul global (BROWN, 2019, p.30). 
Brasileiro (PRB), nos governos petistas se deu desde a sua gênese (governo Lula), até semanas antes do afastamento de Dilma Rousseff. Marcelo Crivella, bispo licenciado da Igreja Universal e sobrinho do Bispo Edir Macedo, foi ministro da Pesca entre 2012 e 2014, durante a gestão de Dilma. Questões econômicas e morais somadas à crise econômica foram incorporadas por segmentos evangélicos ativos na política e cimentaram a aliança com outros agentes em torno da candidatura à presidência de Jair Bolsonaro em 2018.

A afinidade entre a disposição empreendedora e a informalidade e a precariedade do trabalho teve expressão, para Almeida (2019), tanto nos anos de recessão econômica em que o Brasil esteve mergulhado entre os anos 1980 e 1990, quanto nos momentos de expansão de consumo. Em ambas as situações, a disposição para o investimento individual e para o empreendimento, foram incentivadas e celebradas. É interessante observar, no entanto, que a ética econômica adotada se trata de um neoliberalismo que não dispensa totalmente os serviços públicos (saúde, educação, saneamento, seguridade social e segurança, por exemplo). O discurso neoliberal religioso ancora-se, sobretudo, no rechaço à corrupção política e aos privilégios do setor público, agendas francamente neoliberais como a reforma trabalhista, conforme anteriormente mostrado, não possuem tamanha adesão (ALMEIDA, 2019; LACERDA, 2019).

Para melhoria do desempenho de pautas mais restritivas à ação estatal alianças estratégicas entre ultraliberais e defensores das pautas dos costumes e segurança (ALMEIDA, 2019). Essa dinâmica foi observada na eleição não só de Jair Bolsonaro, mas como de diversos outros candidatos a governadores, deputados, senadores e deputados estaduais e federais em 2018. É à discussão sobre a pauta securitária que se ocupa a próxima seção.

\subsubsection{Punitivismo e repressão}

$\mathrm{Na}$ terceira linha de força trazida por Almeida (2017, p.21) encontram-se as demandas securitárias e punitivistas, ela "diz respeito a uma série de movimentações políticas, demandas coletivas, medidas governamentais que apontam para postura e ações mais repressivas e punitivas dos aparelhos de segurança do Estado". Nesse contexto exigem-se repostas mais duras na repressão exercida pelo Estado. Com forte adesão popular, brada-se que "bandido bom é bandido morto", mesmo que isso configure contrário ao princípio do amor ao 
próximo defendido pelo cristianismo e seus dogmas. Pautas como a redução da maioridade penal de 18 para 16 anos, estabelecimento de uma lei antiterror, militarização educacional, políticas de encarceramento mais rígidas, o combate às drogas e outras demandas ganham cada vez mais destaque e defesa por seus adeptos.

Ao analisar o panorama político delineado na última eleição, Almeida (2019) afirma que a eleição de Bolsonaro pode ter sido a principal, mas não é a única expressão do conservadorismo político brasileiro. Para o autor, o fato de o número de deputados e senadores ligados a carreiras na segurança ter saltado de 18 para 73 aponta o grau de espraiamento conservador pela sociedade. Tal reorientação pode indicar a bem-sucedida canalização da insatisfação popular com a baixa capacidade de oferecer respostas imediatas às demandas populacionais (ALMEIDA, 2019).

A chegada dos militares novamente à esfera política ampliou, segundo Almeida, o escopo de atuação da linha de força securitária. A presença expressiva de militares de diferentes patentes na composição do governo Bolsonaro, o que inclui o próprio presidente e seu vice, além de quadros do primeiro escalão, viceja desconfiança sobre os futuros rumos da democracia no Brasil. Se antes a linha securitária se via presa à segurança pública, atualmente busca influir sobre a percepção histórica sobre o período da ditadura militar, vivenciado no Brasil entre os anos 1964 e 1985. Ao apontar uma situação da campanha eleitoral de 2018, Almeida aponta, em uma dura análise, a baixa sensibilidade do eleitorado bolsonarista à questão da tortura existente naquele período. Para o autor, ao reagir com piadas e "memes" aos depoimentos das vítimas da ditadura, apresentados durante o programa eleitoral de Fernando Haddad, os apoiadores do atual presidente não apenas relativizaram as atividades ocorridas, como endossaram as declarações pró tortura de Jair Bolsonaro.

Ainda para Almeida (2019), na disputa de narrativas que se tornou a eleição de 2018, a população optou por aquela que indicava a necessidade de tirar o PT do poder e, assim, destruir a corrupção moral e econômica decorrente dessa gestão, em detrimento de uma outra fundamentada na urgência da defesa dos valores democráticos. Nesse contexto, o voto evangélico teve um grande destaque. Esses agentes sociais também ocupam um lugar importante na última linha de força conservadora a ser discutida, como pode ser visto a diante. 


\subsubsection{Na interação social o diabo são os outros}

Num contexto de interações sociais intolerantes, o crescente antagonismo político ocasiona rompimentos de relações afetivas e cisões nas opiniões públicas. Assim, a quarta linha de força destacada por Almeida (2017) é a chamada interacional. Nessa dimensão, o autor se refere à qualidade e à intensidade das interações sociais em situações de forte antagonismo político. Destacam-se os sentimentos de ódio, fobia e vingança que têm permeado as relações interpessoais, sobretudo desde as manifestações de junho 2013, e demonstradas em redes sociais. Tais ações são concretizadas em atos de iconoclastia, vilipêndios e constrangimento moral, como os sofridos por candomblecistas, pais e mães de santos obrigados a destruir seus próprios terreiros ${ }^{25}$, além da propagação de discursos homofóbicos ${ }^{26}$.

A campanha altamente polarizada, emocional e radicalizada, levou a uma eleição disruptiva ${ }^{27}$. A capacidade de engajar diferentes indivíduos em torno do debate político permite atribuir às redes sociais um papel importante nesse cenário que já se apresenta como um fenômeno global. Ao possibilitar maior capacidade de interação social, os debates políticos digitais foram dominados por discursos difamatórios e indivíduos raivosos. A violência nascida desse contexto social permeado por antagonismos e agressividade exacerbada pode atuar tanto em níveis individuais (ferindo pessoas) como em outros mais amplos (minorando o acesso aos direitos civis e políticos essenciais ao exercício democrática). Ao ameaçar a estabilidade política, dificulta a formação de governos mais capazes de enfrentar os múltiplos desafios que se apresentam. A polarização afetiva experimentada em território brasileiro ganhou contornos semelhantes àqueles observados nos EUA, na Europa e, mesmo na América Latina (ABRANCHES, 2019).

${ }^{25}$ Disponível em: https://cbn.globoradio.globo.com/editorias/policia/2017/09/13/CRIMINOSOSOBRIGAM-MAE-DE-SANTO-A-DESTRUIR-PROPRIO-TERREIRO-EM-NOVAIGUACU.htm Acesso em 08/09/2020.

${ }_{26}$ Disponível em: https://g1.globo.com/mt/mato-grosso/noticia/2020/09/04/crimes-contra-lgbtsem-2020-aumentam-em-108percent-em-relacao-a-2019.ghtml Acesso em 09/09/2020.

27 PT e PSDB foram os principais partidos das eleições presidências desde 1993: https://www.uol/eleicoes/especiais/pt-psdb-eleicoes-2018-polarizacao-partido-ganha-perde.htm Acesso em 09/09/2020. 
Um aspecto importante de ser destacado é o vínculo estabelecido entre polarização política e polarização religiosa. Para Ronaldo Almeida (2019), a frase que melhor expressa essa percepção é "amar o homossexual, mas ter repulsa ao homossexualismo". À degeneração moral oriunda da depravação homossexual foi creditada a ruína da família tradicional brasileira. É preciso ter em mente que para os neoconservadores a deterioração do tecido social é atribuída à (falta de) força da família patriarcal, tal como informa Lacerda (2019).

Ao olhar para o conjunto de atuação das linhas de força apresentadas até aqui, é possível perceber que a onda conservadora quebrada em diferentes frentes apresentada por Ronaldo Almeida (2017) em muito dialoga com o cenário neoconservador discutido por Marina Lacerda (2019). A conjuntura político social vigente articula aspectos morais, securitários, econômicos e interacionistas. Em tal contexto a educação figura como um importante campo em disputa que envolve ações e programas específicos. As diferentes demandas por instrução, disputas curriculares e orientação da perspectiva educacional a ser adotada trazem em si diferentes concepções de sociedade, organização cultural e socioeconômica que não podem ser ignoradas (ROSA, 2018). É à discussão do lugar ocupado pela educação nesse contexto que passo a seguir. 


\section{A educação como um campo em disputa: o conservadorismo educacional em ação}

Se por um lado a ideia da escola enquanto importante espaço de socialização dos indivíduos é amplamente aceita, por outro é preciso ter em mente que os valores veiculados, as práticas e sujeitos que nela habitam estão em constante disputa. Para Michael Apple, teórico educacional norte-americano, a educação ocupa ao mesmo tempo os lugares de "causa" e "efeito" nas batalhas sobre suas funções. Em suas palavras, "os recursos, o poder e a ideologia se desenvolvem relacionando-se com as políticas, o financiamento, o currículo, a pedagogia e a avaliação. Deste modo, a educação é simultaneamente [...] determinada e determinante (APPLE 2002, p.56)". Assim, uma discussão que se pretenda analítica e elucidativa sobre as investidas neoconservadoras no campo educacional não pode se furtar a refletir sobre toda a complexidade que envolve esta conjuntura.

Deste modo, a retórica conservadora com frequência lança mão de argumentos baseados no fracasso da escola como instituição. A elevada indisciplina dos alunos, a incapacidade de formá-los para a inserção no mercado de trabalho, a tentativa de sobrepor a autoridade familiar através de currículos e conteúdo das diferentes disciplinas, entre outras acusações, figuram como exemplos desse fracasso. Tais críticas compartilham uma essência básica: o desprezo pelos valores igualitários e o entendimento da democracia política e cultural em demasia como fonte do declínio moral, econômico e social moderno.

Ora moralizantes, ora economicistas e securitários, os ataques aos ideais democratizantes no plano educacional nem sempre são desferidos de maneira direta e assertiva. Ao analisar as investidas neoconservadoras sobre a educação nos EUA, Apple (2002) aponta que termos como "competividade" e "eficientização escolar" surgem associados a conflitos culturais e dinâmicas subalternização de raça e gênero tanto em discursos políticos, propagandas empresárias, editoriais jornalísticos, quanto em políticas públicas voltadas para a educação desde os anos 1980.

Para o autor, a "modernização conservadora" da educação resulta de um processo social maior, a "restauração conservadora", sendo esta última fruto da aliança consensual entre diferentes grupos da direita política norte-americana (FIGURA 2). 

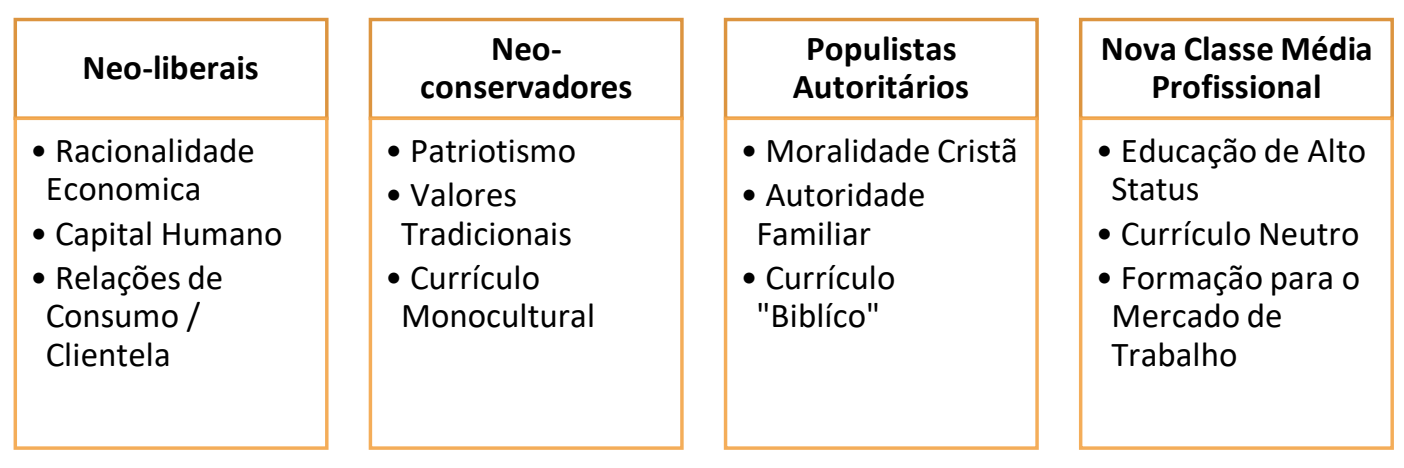

Figura 2: Integrantes da aliança conservadora na educação e seus principais integrantes, segundo Michael Apple (2002).

Ao construir um consenso capaz de organizar sob um guarda-chuva maior objetivos diferentes, e por vezes contraditórios, a aliança conservadora conseguiu projetar seus ideais sobre as múltiplas dimensões sociais (ALMEIDA, 2017; LACERDA, 2019). A pluralidade de interesses e integrantes do conservadorismo educacional decorre dessa pluralidade de tendências do conservadorismo político e social como um todo. A educação integra, pois, esse conjunto (APPLE, 2002).

Entendo que as reflexões realizadas pelo teórico em questão se inserem num contexto específico, a reforma educacional estadunidense iniciada entre os anos 1980 e 1990. Porém, assumo, tal como Lacerda (2019), que os eventos ocorridos na história brasileira recente mostra grandes paralelos com aqueles vivenciados em contextos internacionais, sobretudo nos Estados Unidos da América. Portanto, trago tais discussões para compor as análises que realizo. Assim, busco me debruçar de maneira mais cuidadosa sobre tais grupos de interesse e mecanismos de ação para, a partir deles, traçar paralelos e identificar divergências com o momento de ascensão conservadora na educação que vivenciamos no Brasil de hoje.

\subsection{Racionalidade econômica e restauração cultural: os objetivos da modernização educacional conservadora}

Retomo a conceituação de neoliberalismo apresentada anteriormente: o neoliberalismo se baseia fundamentalmente na liberdade individual, na eficiência e no lucro de uma sociedade de livre mercado (HARVEY, 2007). No que se refere à educação, a racionalidade econômica tem na eficiência, na análise de custobenefício e no entendimento do aluno como capital humano seus principais marcos estruturantes. Os currículos, os tempos de aula, os espaços físicos, os objetivos e 
valores que regem o processo educacional, nessa perspectiva, devem favorecer o desenvolvimento de disposições e habilidades mais ajustados à competividade do "mundo real" externo aos muros das escolas. Os alunos, como futuros trabalhadores que são, devem, então, receber uma formação teórico-metodológica que lhes permitam adquirir destrezas e desenvolver posturas próprias à inserção bemsucedida no mercado de trabalho que tende a se complexificar cada vez mais (APPLE, 2002; 2003).

A perspectiva neoliberal de sociedade, segundo Apple (2003), transforma a o conceito da democracia de algo político e, por natureza coletivo, em uma relação de consumo individualizada e imediatista. A escola nesse contexto figura como mais um serviço e educação como produto que deve ser tornar mais eficiente ao gosto do consumidor. Nesse ponto é importante salientar que diferentes tipos de consumidores: aqueles que, de fato, podem optar por produtos semelhantes ou diferentes, e aqueles que precisam se contentar com a imagem dos produtos que deseja, o chamado "consumismo pós-moderno". Duas possibilidades de atuação neoliberal decorrem desse nó tático: i. o financiamento estudantil via política de "vouchers" e ii. a competição por recursos público/privados entre as diferentes instituições escolares (APPLE, 2002).

Em uma contextualização histórica, Joel Spring, acadêmico norteamericano, aponta que a defesa de um processo educacional voltado para a aquisição de habilidades e competências necessárias ao trabalho futuro não é algo recente. Dentro do ideário neoconservador a Escola de Chicago, sobretudo nas figuras de Milton Friedman, Gary Becker, Theodore Schultz e James Heckman, aplicou o pensamento econômico à educação de maneira contundente. A "economização da educação", portanto, carrega o "envolvimento de economistas na pesquisa em educação, na avaliação da eficiência de escolas e da vida familiar segundo análises de custo-benefício, e na promoção da concorrência entre escolas em um ambiente competitivo (SPRING, 2018, p. 14)".

Ainda segundo Spring (2018), em "O papel do governo na educação" de 1955, Friedman ganhou bastante notoriedade com sua proposta de vouchers educacionais. Para o autor, ao permitir que as famílias escolhessem as escolas em que seus filhos estudariam de acordo com sua própria vontade, abria-se a possiblidade de que estudantes moradores de áreas com escolas ruins pudessem se matricular em áreas com estabelecimentos de melhor qualidade - públicos ou 
privados. Nesse raciocínio, o efeito vizinhança negativo seria superado, e, além disso, a competição entre escolas estimularia a melhoria da qualidade da educação ofertada.

Tanto Apple (2002, 2003), quanto Spring (2018) apontam que a ênfase em uma educação voltada para o capital humano e centrada no desenvolvimento habilidades, ao valorizar unicamente àquelas ligadas às ciências exatas e biológicas, preterindo-se as humanas e as artes, gera duas consequências: o impacto direto sobre recursos e estímulos aos cursos superiores nas áreas preteridas, e o não desenvolvimento habilidades necessárias ao engajamento dos indivíduos nas lutas por justiça social, como a compaixão e altruísmo, a exemplo. Sobre a política de vouchers, ambos ressaltam que sua implementação não elimina a existência de escolas segregadas por raças, algo que, segundo Spring (2018), o próprio Friedman reconhecia.

A fim de adicionar a esta discussão dados empíricos sobre a implementação das políticas de voucher e de escolha da escola, ambas voltadas para o financiamento público/privado da educação trazidas por Apple $(2002,2003)$ como uma das variantes da atuação neoliberal, busquei estudos que as abordassem. Assim, segundo Helen Ladd (2003), pesquisadora norteamericana das relações entre política econômica e educação, as experiências envolvendo vouchers nos EUA são pequenas e de evidência limitada sobre seus efeitos na qualidade de escolas públicas tradicionais. Em consequência, boa parte do debate naquele país se daria em torno de disputas ideológicas com pouquíssima materialidade.

Em outros contextos em que a política de vouchers foi aplicada em âmbito nacional, como no Chile, pesquisas mostram que houve um crescimento expressivo de escolas privadas, não-religiosas e com fins lucrativos. Todavia, os estudantes dessas escolas não apresentaram desempenho superior aos das escolas públicas tradicionais. Apenas estudantes de escolas católicas tiveram melhores resultados, mas Martin Carnoy e Patrick McEwan (2003) atribuem isso aos maiores recursos que esses estabelecimentos possuíam. Os autores enfatizam, ainda, que os pais tendem a escolher as escolas com base em suas características socioeconômicas e étnicas, o que fez com que filhos de pais mais escolarizados frequentassem escolas em que os colegas tinham perfil semelhante, aprofundando desigualdades que já existiam anteriormente. De uma maneira geral, o programa tendeu a favorecer alunos de classes mais altas. 
Em pesquisa recente, Alvaro Hofflinger e Paul von Hippel (2020) testaram se o aumento de desempenho dos estudantes chilenos entre 2002 e 2013 se deveria à escolha da escola, aos recursos escolares ou aos recursos familiares. A conclusão do estudo é que o principal fator foi o aumento da educação dos pais, seguido pela redução do tamanho das turmas. O sistema de choice, ou seja, de escolha da escola não teve impacto estatisticamente significativo.

Retorno à Michael Apple para o fechamento desta subseção. Para o teórico, atribuir à escola o dever de adequar os alunos a um mundo mais competitivo enquanto atrela ao mercado a capacidade de transformação social e educacional justa servem a duas funções: i. a romantização das condições de desigualdade de recurso e poder estruturantes da sociedade neoliberal e ii. a terceirização das responsabilidades pelas mazelas sociais existentes. Ao redefinir o sentido do processo educacional não como espaço de socialização e formação em valores democráticos e plurais, mas sim como um serviço marcado pela lógica da eficiência econômica, as investidas neoliberais se valem de um mecanismo maior de transformação dos sentidos das necessidades sociais ao senso comum. Em suas palavras,

... se as pessoas clamam por "mais democracia" e por um Estado mais responsável, o importante [para as classes dominantes] é não entregar "valores" que consigam fazer cumprir com essa exigência [...]. Pelo contrário, importa transformar o que na realidade conta como democracia. No caso das políticas neoliberais, a democracia é redefinida como garantia de escolha num mercado livre. Em essência, a retirada do Estado (APPLE, 2002, pág.64).

O sucesso em redefinir as fronteiras entre o domínio público e o privado empurra o "senso comum" das pessoas em direção a uma perspectiva conservadora durante períodos de crise política, econômica e social. Deste modo, o neoliberalismo enquanto política pública econômica implica livre comércio e diminuição do Estado, logo garantias próprias de um Estado de Bem-Estar dão lugar à acumulação flexível e à mercantilização das relações sociais. As contradições que emergem em uma realidade de disparidades de acesso, precarização das relações de trabalho e insegurança financeira demandam respostas enérgicas a fim da manutenção da ordem e progresso social (BROWN, 2015; HARVEY, 2017). O punitivismo e moralização religiosa são apontadas como respostas 
neoconservadoras aos problemas gerados pelo Estado Mínimo neoliberal (LACERDA, 2019).

No que se refere à educação, Apple $(2002$, 2003) atribui aos neoconservadores e aos populistas autoritários o papel de zelar pela integridade cultural e moral em uma era de degenerações do tecido social. Destaco que, embora Michael Apple utilize o termo neo-conservadores (com esta grafia) como alcunha de um grupo específico dentro da aliança conservadora educacional, ao longo desta tese de doutoramento utilizo o termo neoconservadores de maneira mais ampla e inclusiva a todos os integrantes da ofensiva neoconservadora. $\mathrm{O}$ faço a partir do entendimento que o conservadorismo enquanto perspectiva filosófica ao adotar as pautas sobre sexualidade e moralidade cristã formam o movimento político neoconservador, tal como Marina Lacerda (2019).

Assim, os neo-conservadores, para Apple (2002) são aqueles que baseiam suas propostas em um "regresso ao passado" e ao "medo do outro". O compromisso com os "valores tradicionais", a saber patriotismo, honestidade, caráter moral e a disposição empreendedora, somam-se aos ataques ao bilinguismo, ao multiculturalismo e ao apoio as chamadas "Charter Schools", escolas com características individualizadas e de currículo adaptado aos gostos da clientela financiadas pelo dinheiro público.

Já os populistas autoritários caracterizam-se pela agressividade com que perseguem seus objetivos, o apaixonado ativismo de seus partidários e a proximidade com a Direita Cristã dos EUA. Para este grupo a duas autoridades devem guiar a educação nacional: a cristã e a familiar, sendo esta última divinamente inspirada. A "moral cristã", a "correta função dos gêneros e dos comportamentos sexuais", a "família como base da sociedade" e o "devido controle do processo de escolarização" são as frentes de ação dos neo-conservadores tanto no plano político em geral, quanto, especificamente, no plano educacional. Somadas as reinvindicações de ambos os grupos um caminho desponta: o autoritarismo como ideologia educacional (APPLE, 2002).

Um aspecto importante do neoconservadorismo voltado para a educação é o estabelecimento do controle parental, moral e religioso sobre seus filhos quando em ambiente escolar. A defesa dessa perspectiva gira em torno das prerrogativas parentais biológicas e ideológicas sobrepostas às estatais. Entre as medidas propostas pelos grupos pró-família ligadas à direita cristã nos EUA dos anos 1980, 
chamam atenção: a reintrodução de orações nas escolas públicas, o ensino do criacionismo, a oposição a qualquer do governo federal sobre as escolas privadas e religiosas, incentivos fiscais para matrícula de crianças em idade escolar em escola privadas e religiosas, oposição à sindicalização de professores da rede pública, eliminação de todos os programas relacionados à educação sexual, homossexualidade e de visão crítica com relação aos papéis sexuais tradicionais, demissão de professores homossexuais de escolas públicas e a reivindicação do homeschooling, em oposição à contracultura que dominou a escola pública nos anos 1960 e 1970 (LACERDA, 2019).

O homeschooling é outra frente dessa investida neoconservadora na educação. Apple (2003) argumenta que seus defensores são majoritariamente grupos religiosos evangélicos conservadores. Tendência crescente nos EUA desde os anos 1980, a maior parte das famílias que adotam o homeschooling são de brancos, mais escolarizados e ricos do que a média da população. Os programas e materiais didáticos utilizados possuem conteúdos, orientações pedagógicas e morais profundamente marcados por valores religiosos. Chama atenção que a maioria dos responsáveis pela educação dos filhos é formada pelas suas mães, o que é condizente com os papéis de gênero defendidos por essas denominações religiosas.

Por fim, para Apple (2002) há um grupo que providencia o apoio técnico às investidas neoliberais e aos arroubos autoritários neo-conservadores religiosos do cenário educacional: a nova classe média profissional. Mesmo sem total endosso às crenças ideológicas extremas dos demais integrantes da aliança conservadora educacional, estes indivíduos veem com bons olhos a rigidez dos processos educativos pautados na autoridade familiar, no conteúdo tradicional de "alto status" e na preocupação com a inserção no mercado de trabalho, dada sua tendência natural à direita política e o medo de perderem seus postos de trabalho ou o rebaixamento de classe social de seus herdeiros num mundo incerto.

É interessante observar a já mencionada capacidade de consenso produzida pelos integrantes dessa aliança pró modernização conservadora da educação, visto que algumas características parecem irreconciliáveis a um primeiro olhar. Se os neoliberais preconizam um Estado fraco, os neo-conservadores demandam um Estado forte. Se novos integrantes da classe média nem sempre endossam o neoconservadorismo religioso, quando numa situação de incerteza econômica o 
acolhem com boa vontade dado a seu rigor quantos conteúdos e valores educacionais. Ao produzir uma relação mercantilizada pautada pelo consumo, a redefinição de fronteiras entre domínio público e privado ao mesmo tempo em que promove um duro processo de moralização religioso dos corpos e comportamentos, as investidas neoconservadoras aparam arestas e reforçam a aliança que lhes deu origem (APPLE, 2002).

A partir desse movimento teórico passo agora a refletir sobre as disputas travadas em torno da educação brasileira atual.

\subsection{A educação brasileira em jogo: os tentáculos do neoconservadorismo educacional em ação}

O avanço da ofensiva conservadora no Brasil não é algo iniciado nos últimos dois anos, tal como explorado na introdução deste trabalho. No entanto, para pensar a situação educacional vigente começo essa reflexão salientando a relevância do compromisso público assumido Jair Bolsonaro e sua equipe, desde o início de sua campanha eleitoral, em relação à defesa dos valores familiares e cristãos e da reorientação à direita no campo educacional. Assumidamente conservador, as dinâmicas econômicas, morais e culturais discutidas até o momento eram possíveis de observar a cada aparição pública do então candidato ao Executivo.

Também é preciso apontar as diferentes crises pelas quais o Ministério da Educação - MEC passou até o presente momento. Em seu quarto gestor desde janeiro de 2019, o MEC se mostrou sempre alinhado ao ideal conservador inerente ao governo Bolsonaro. Ricardo Vélez, teólogo e filósofo colombiano ${ }^{28}{ }^{29}$, foi o primeiro a ocupar o cargo de Ministro da Educação, e o fez por pouco tempo $\left(1^{\circ}\right.$ janeiro - 8 abril de 2019), não se sustentou após o envolvimento em diversas polêmicas e pediu demissão: declarações relacionadas ao comportamento do brasileiro fora do país ("parecem canibais"), solicitação de filmagem dos alunos cantando o Hino Nacional nas escolas públicas de todo país (voltando atrás após

28 Bolsonaro pede apoio à agenda do Governo. Disponível em: https://www12.senado.leg.br/noticias/materias/2019/02/04/em-mensagem-ao-congressobolsonaro-pede-apoio-a-agenda-do-governo, acesso em 21/07/2020.

29 Ministro da Educação causa polêmicas. Disponível em: https://g1.globo.com/jornalnacional/noticia/2019/02/05/ministro-da-educacao-causa-polemica-com-declaracoes.ghtml, acesso em 21/07/2020. 
repercussão negativa), apoio ao revisionismo histórico envolvendo o período ditatorial brasileiro, entre outras ${ }^{30}$.

Após a sua demissão, Abraham Weintraub, economista formado pela Universidade de São Paulo (USP) e docente na Universidade Federal de São Paulo (UNIFESP), ocupou o cargo de Ministro, permanecendo até 20 de junho 2020. E, apesar do constante envolvimento em polêmicas (corte de financiamento às universidades, ataques a figuras públicas em redes sociais, erros de ortografia em suas publicações oficiais, entre outros), o segundo ex-titular da pasta caiu ${ }^{31} \mathrm{em}$ função de suas críticas aos integrantes do Supremo Tribunal Federal (STF) expostas em rede nacional após a veiculação de uma reunião ministerial por determinação da justiça ${ }^{32}$

Em uma tentativa de apaziguar as polêmicas geradas por Weintraub e a base aliada preocupada com os rumos ideológicos até então tomados pela instituição, Bolsonaro indicou o professor economista Carlos Decotelli ao cargo de ministro em 25 de junho de 2020. Mas, após o crescente mal-estar provocado por uma série de desmentidos acerca de seu currículo e formação, Decotelli não chegou a tomar posse e renunciou cinco dias após sua nomeação ${ }^{33}$. Até o momento da escrita deste texto, o ministro da Educação é Milton Ribeiro. Formado em Direito e Teologia, Ribeiro é pastor de uma igreja Presbiteriana em Santos (SP)assume assumiu a tarefa de "pacificar" o MEC. Logo que tomou posse, em 16 de julho de 2020, um vídeo em que defende castigos físicos como forma de disciplinar e ensinar as crianças em sua congregação circulou nas redes sociais ${ }^{34}$ e, mais recentemente, afirmou que "gays vêm de famílias desajustadas" "35. Cabe destacar a participação da bancada

30 https://g1.globo.com/politica/noticia/2019/04/08/planalto-anuncia-demissao-de-ricardo-velezrodriguez-do-ministerio-da-educacao.ghtml. Disponível em 21/07/2020

31 https://www1.folha.uol.com.br/colunas/monicabergamo/2019/11/aliados-de-bolsonaroreclamam-que-weintraub-causa-conflitos-tentando-adotar-estilo-do-presidente.shtml. Disponível em 21/07/2020.

${ }^{32}$ Após a saída do ex-juiz Sérgio Moro do Ministério da Justiça, o ex-ministro acusou o Presidente Jair Bolsonaro de tentar interferir em casos em andamento relacionados a sua família. Por determinação do STF a reunião ministerial apontada por Moro como palco dessa ingerência foi divulgada ao público: https://g1.globo.com/politica/noticia/2020/05/22/veja-os-principais-pontosda-reuniao-ministerial-que-teve-gravacao-divulgada-pelo-stf.ghtml. Disponível em 21/07/2020

33 Carlos Decotelli atribuiu sua queda meteórica ao racismo e antibolsonarismo https://www.bbc.com/portuguese/brasil-53312912 Disponível em 21/07/2020.

${ }^{34}$ Milton Ribeiro defende a vara da disciplina: https://oglobo.globo.com/sociedade/novo-ministroda-educacao-ja-defendeu-educar-criancas-com-dor-24528082 disponível em 21/07/2020.

35 Ministro da educação dá declarações homofóbicas em entrevista: https://g1.globo.com/educacao/noticia/2020/09/24/ministro-da-educacao-diz-que-gays-vem-defamilias-desajustadas-e-que-acesso-a-internet-nao-e-responsabilidade-do-mec.ghtml Acesso em $25 / 09 / 2020$ 
evangélica em cada uma dessas indicações ${ }^{36}$, bem como na rejeição de outros nomes para liderança do MEC. As falas apresentadas pelo atual ministro, o pastor Milton Ribeiro, indicam a proximidade de suas ideias com a pauta moral discutida anteriormente. Discursos deste porte podem não ter efeito de lei, mas apontam para onde pende a bússola moral bolsonarista: a defesa da família patriarcal heteronormativa como base da sociedade.

A literatura nacional e internacional vem destacando, conforme discutido até o momento, eixos de atuação conservadora tanto no plano social mais amplo, como no caso específico da educação: mercantilização das relações sociais, moralização religiosa dos corpos e comportamentos, resgate dos valores tradicionais e estímulo ao antagonismo político e sociocultural (APPLE, 2002; 2003; ALMEIDA, 2017; LACERDA, 2019). Neste trabalho elenco essas áreas como foco de interesse investigativo. É impossível pensar a investida conservadora sobre a educação pública brasileira sem considerar os ataques e duras críticas recebidas especialmente após as manifestações de 2013, movimento de forte influência sobre afastamento de Dilma Rousseff da presidência. Pautas como os projetos de lei "Escola sem Partido", o combate à chamada "ideologia de gênero" e à "influência de Paulo Freire na educação nacional" integraram o guarda-chuva de acusações voltadas ao Governo Federal (QUINALHA, 2019).

Para além das demandas morais, é possível destacar a atuação de grupos empresariais e filantrópicos no avanço da privatização da gestão e da oferta educacional e, principalmente, dos currículos no Brasil. A formulação e implementação de políticas como a Base Nacional Comum Curricular, a Reforma do Ensino Médio e o programa Future-se exemplificam essas demandas com clareza (ADRIÃO, 2018; AVELAR, 2019; AVELAR; BALL, 2019; CORTI, 2019). A implementação do modelo de escolas cívico-militares e os discursos em favor do resgate da autoridade perdida dos professores, representam as demandas conservadoras voltadas ao resgate de uma educação disciplinadora. A retórica em defesa desse modelo de administração escolar se escora na promoção de valores humanos, éticos e morais, da formação integral do cidadão e de aumento do sentimento de pertencimento ao ambiente escolar (PERA, 2019).

\footnotetext{
36 Influência da bancada evangélica nas indicações ao MEC: https://congressoemfoco.uol.com.br/educacao/bancada-evangelica-nega-interferencia-na-escolhade-novo-ministro-da-educacao/ Acesso em: 14/11/2020.
} 
Sobre às investidas socialmente intolerante sobre o campo educacional, é possível encontrar marcas dessa dimensão na desqualificação do trabalho docente e das escolas, consequência de uma perspectiva de constante vigilância e de perseguição a professoras e professores que são vistos como doutrinadores. Em resposta ao ambiente de vigilância que tomou a educação brasileira, já tem sido noticiados casos de autocensura por parte de professores que temem possíveis punições e demissões por abordarem temáticas ligadas à política, comunismo e a ditadura militar (FAGUNDEZ, 2018). É importante observar que tais demandas aglutinam-se num contexto maior de consenso neoconservador: a defesa da articulação de pautas morais e políticas de diminuição do Estado e instituição das relações de consumo como norteadores da vida em sociedade em detrimento do investimento em valores e políticas públicas mais plurais, democráticas, inclusivas e tolerantes (APPLE, 2002; 2003).

Acredito que mapear tais investidas, conhecer suas estratégias e principais objetivos pode favorecer a construção de estratégias de enfrentamento e mobilização social em torno de um processo de escolarização que se pretenda menos conservador e mais emancipatório. 


\section{Revisão de literatura: o que o campo tem a dizer}

Nenhuma pesquisa, por mais exploratória que seja, parte do nada absoluto (LAKATOS; MARCONI, 1991). Seja através da complementação dos dados existentes ou das extrapolações experienciadas em contextos distintos, para as autoras em questão, é perfeitamente possível situar uma investigação em andamento dentro de um quadro maior. Assim, a fim de entender como o campo acadêmico vem percebendo a dinâmica conservadorismo/educação dentro e fora do país, procurei em teses, dissertações e artigos publicados ao longo dos últimos dez anos indicadores, tendências e redes de significados a ela relacionados. Adianto que apenas artigos e periódicos internacionais foram trazidos para compor esse panorama, conforme explicarei a seguir.

\subsection{Etapas e procedimentos da revisão de literatura}

O percurso metodológico percorrido durante este levantamento seguiu cinco estágios que, de modo geral, podem ser chamados de: i. A busca, ii. Os critérios, iii. A leitura, iv. A análise e, por último, v. A comunicação. Tal estrutura foi livremente inspirada pela metodologia de Revisão Bibliográfica Sistemática apresentada por Raquel Coutinho e Paula Miranda-Ribeiro (2014). Em seu estudo as autoras buscaram produzir um levantamento bibliográfico sobre religião, religiosidade e juventude num período superior a meio século em bases de dados radicadas no Brasil e em outros países. As autoras partem de uma premissa inicial bem delimitada e estabelecem critérios de exclusão / inclusão dos dados a priori. Posteriormente, buscam nas obras encontradas os aspectos metodológicos, principais resultados, ênfase e conclusões. Estes recortes são colocados em planilhas e depois analisados. O relato dos achados é feito a partir de uma divisão clara: tendências encontradas nos textos brasileiros / tendências encontradas no "mundo". Por fim, as autoras produzem algumas considerações para estudos futuros sobre a dinâmica "religião e juventude".

Opto por adaptar esta abordagem metodológica revisional por entender que os achados por ela produzidos podem favorecer a construção de índices e chaves de leitura que auxiliarão a análise que me proponho a fazer nesta tese de doutoramento. 
Cada etapa realizada conta com uma série de estratégias e escolhas a fim de produzir um material representativo da produção acadêmica recente sobre a temática de interesse deste trabalho.

\subsubsection{Etapa 1 - A busca inicial: sobre os recortes, as fontes e os primeiros achados}

Realizada entre setembro e novembro de 2020, e atualizada em março de 2021, a busca por publicações acadêmicas relacionadas ao tema "(neo)conservadorismo e educação" 37 teve como recorte temporal utilizado o período de 2010 a 2021. Tal opção se deu tanto pela atualidade imediata dos achados, quanto pelo entendimento de que é neste período em que os processos políticos de cunho conservador ganharam contornos, capilaridade social e alcançam seu auge tanto no Brasil, como em outros países da Europa e da América (LACERDA, 2019).

As fontes utilizadas no levantamento foram: a Biblioteca Digital de Teses e Dissertações (BDTD), o Catálogo de Teses e Dissertações da CAPES, e o portal Scientific Eletronic Library Online (SciELO) e o Scopus - base internacional de dados da Elsevier. Tais bancos de dados foram escolhidos pela relevância exercida na disseminação do conhecimento científico produzido em diferentes contextos. É importante dizer que cada base de dados apresenta um layout característico e exige algum conhecimento sobre os filtros a serem aplicados numa busca específica. Assim, as palavras-chave utilizadas nos buscadores eletrônicos foram adaptadas as especificidades de cada um (Quadro 3).

Enquanto os mesmos termos puderam ser utilizados nas bases BDTD e SciELO, na Scopus precisaram ser traduzidos para o inglês, idioma da página. Já na base de dados da CAPES os termos foram transformados em expressões dentro de uma área do conhecimento específico, a Educação, para adequarem-se ao portal em questão. O uso de recursos como aspas (“"), para correspondência exata, de expressões em inglês como AND, para concomitância, teve como objetivo tornar a busca mais diretamente relacionada ao tema de interesse desta investigação. Os

\footnotetext{
37 Opto por escrever o termo "(neo)conservador" com o prefixo entre parênteses para destacar a utilização das palavras-chave do levantamento produzido, "conservadorismo" e "neoconservadorismo". Essa escolha se deu por entender que optar por uma outra poderia levara perda de resultados durante a busca.
} 
termos ou expressões buscadas deveriam constar nos títulos, resumos e/ou palavraschaves de cada publicação.

\begin{tabular}{|c|c|c|c|}
\hline Scopus & BDTD & CAPES & SciELO \\
\hline $\begin{array}{c}\text { "conservatism" } \\
\text { AND } \\
\text { "education" }\end{array}$ & $\begin{array}{c}\text { "conservadorismo" } \\
\text { AND } \\
\text { "educação" }\end{array}$ & $\begin{array}{l}\text { "Conservadorismo } \\
\text { e/na educação" }\end{array}$ & $\begin{array}{l}\text { "conservadorismo" } \\
\text { AND } \\
\text { "educação"; }\end{array}$ \\
\hline $\begin{array}{c}\text { "neoconservatism" } \\
\text { AND } \\
\text { "education" }\end{array}$ & $\begin{array}{c}\text { "neoconservadorismo" } \\
\text { AND } \\
\text { "educação" }\end{array}$ & $\begin{array}{c}\text { "neoconservadorismo } \\
\text { e/na educação" }\end{array}$ & $\begin{array}{c}\text { "neoconservadorismo" } \\
\text { AND } \\
\text { "educação" }\end{array}$ \\
\hline $\begin{array}{c}\text { "religious } \\
\text { conservatism" } \\
\text { AND } \\
\text { "education" }\end{array}$ & $\begin{array}{c}\text { “conservadorismo } \\
\text { religioso" } \\
\text { AND } \\
\text { "educação"; }\end{array}$ & $\begin{array}{c}\text { “conservadorismo } \\
\text { religioso e/na } \\
\text { educação" }\end{array}$ & $\begin{array}{c}\text { "conservadorismo } \\
\text { religioso" } \\
\text { AND } \\
\text { "educação"; }\end{array}$ \\
\hline
\end{tabular}

Ressalto que a busca realizada não tem o objetivo de ser definitiva ou exaustiva, mas sim representativa, ou seja, a finalidade principal desse esforço revisional era encontrar textos que trabalhassem o conservadorismo e/ou o neoconservadorismo na educação ou utilizassem estas dinâmicas como aspectos relevantes através dos buscadores anteriormente apresentados. Tenho absoluta clareza que a dinâmica que discuto está diretamente ligada às discussões sobre gênero/sexualidade, estudos sobre ensino religioso e implicações religiosas sobre determinadas disciplinas, discussões sobre multiculturalismo, financiamento estudantil e afins. No entanto, dada a natureza da pesquisa de revisão bibliográfica e os objetivos propostos, entendo que ampliar o leque de opções de tal maneira tornaria o empreendimento viável. Assim, assumi os limites desta escolha confiante de que amostras dessas temáticas relacionadas surgiriam em maior ou menor volume. Posso adiantar que tal confiança se mostrou justificada, conforme apresentarei futuramente.

Dito isso, é possível, então, observar no Quadro 4 os resultados obtidos em números absolutos nessa primeira etapa. 


\section{Scopus BDTD CAPES ScIELO TOTAL}

\section{\begin{tabular}{l|l|l|l|l|}
169 & 111 & 46 & 31 & 357
\end{tabular}}

Quadro 4: Número de documentos encontrados na primeira fase do levantamento bibliográfico. Fonte: AUTORA (2021).

As 357 publicações encontradas nessa fase inicial do levantamento bibliográfico foram salvas numa pasta nomeada com a base de dados correspondente. Tendo consciência da possibilidade de baixas correspondências de sentido e repetições entre os documentos encontrados uma nova etapa do levantamento foi iniciada: a definição de critérios que tornassem o corpus documental adequado aos objetivos revisionais.

\subsubsection{Etapa 2 - Os Critérios de manutenção: que fica e o que sai}

Nesta segunda etapa, todas as 357 publicações foram reavaliadas a partir dos seguintes critérios: $(a)$ ter a dinâmica educação/(neo)conservadorismo como elemento relevante no texto científico; $(b)$ apresentar religião e política como componentes constitutivos das argumentações, e $(c)$ permitir acesso aos textos completos em PDF. Os primeiros critérios, $a$ e $b$, foram elencados como forma de garantir a pertinência dos textos para a revisão empreendida, já o último, $c$, tinha por objetivo permitir a leitura de partes dos textos quando assim se fizesse necessário. Aquelas que não cumpriam todos os requisitos citados foram excluídos do corpus revisional. Vale destacar que para refinar esses dados foi preciso ler todos os resumos e, quando em dúvida, o inteiro teor dos documentos em questão.

De acordo com os critérios estabelecidos, o novo corpus revisional passou a apresentar um volume mais modesto de documentos, mas ainda assim desafiador (Quadro 5).

\section{Scopus BDTD CAPES ScIELO TOTAL

\begin{tabular}{l|l|l|l|l|}
55 & 30 & 16 & 15 & 116
\end{tabular}

Quadro 5: Total de documentos dividido por origem após a segunda etapa de tratamento dos dados. Fonte: AUTORA (2021)

Ao final da segunda etapa do tratamento dos dados, 116 documentos foram identificados como aptos a integrar a revisão de literatura intencionada, pois traziam como temática principal ou de grande relevância as discussões sobre o 
conservadorismo educacional. Após a delimitação do corpus foi preciso passar para uma nova etapa do levantamento: leitura minuciosa dos resumos e flutuante do inteiro dos textos encontrados.

\subsubsection{Etapa 3 - A leitura: o que dizem as obras}

A terceira etapa do levantamento contou com a leitura dos resumos das obras em detalhes e com a leitura flutuante da obra como um todo. Após a leitura e o fichamento destes textos, cada um foi armazenado numa planilha correspondente à base de dados originária no programa Microsoft Excel a partir das seguintes variáveis: 1. Autoria, 2. Ano, 3. Filiação/País de Origem, 4. Resumo, 5. Aspectos Metodológicos e 6. Principais Resultados. Esta etapa serviu não apenas à organização dos achados, como também à identificação de obras que apesar de terem cumprido as primeiras etapas de maneira satisfatória, mostram-se desviantes do objetivo central da busca - o tratamento do conservadorismo educacional como um elemento relevante na obra. Textos que apenas citavam a dinâmica conservadora na educação sem aprofundar reflexões e análises sobre a temática foram descartados do corpus da revisão. $O$ número final de textos a serem analisados passou a ser 100 (Quadro 6).

\section{Scopus BDTD CAPES ScIELO TOTAL

\begin{tabular}{|l|l|l|l|l|}
42 & 28 & 16 & 14 & 100
\end{tabular}

Quadro 6: Número de documentos consolidados após a terceira etapa do levantamento bibliográfico realizados. FONTE: AUTORA (2021)

\subsubsection{Etapa 4 - Análise}

A penúltima etapa da revisão de literatura realizada contou com a análise dos textos obtidos nas diferentes bases de dados. Antes de me debruçar sobre os aspectos qualitativos do levantamento, busquei identificar aspectos quantitativos dos achados, tais como quantidade de publicações por base de dados, frequência ao longo dos anos, distribuição de publicações no Brasil e no mundo. Tal opção se deu por entender que tais quantificações permitiriam contextualizar os dados qualitativos futuramente discutidos. 
Desse modo, a amostra revisional contou com 11 teses, 33 dissertações e 50 artigos científicos publicados em revistas e periódicos. A proporção entre pesquisas de teses, dissertações e artigos científicos aponta maior número de publicações nacionais (Figura 3).

\section{Publicações Acadêmicas Relacionadas ao (Neo)Conservadorismo Educacional}

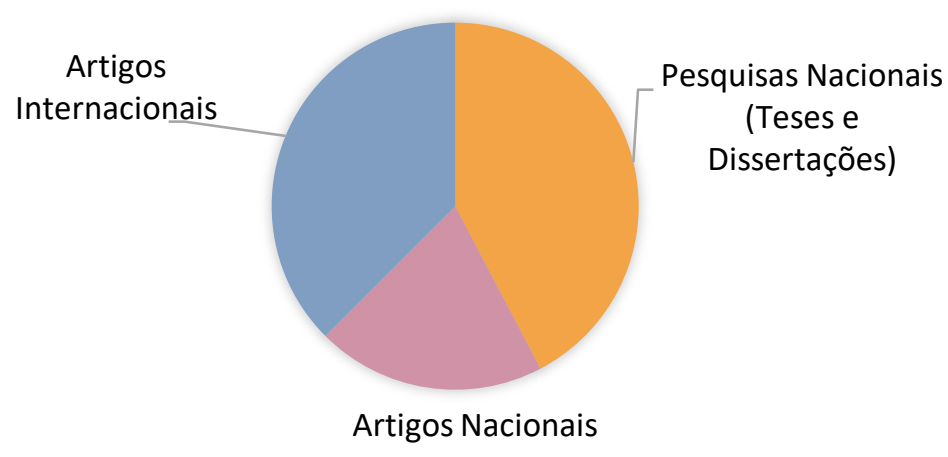

Figura 3: Proporção de textos encontrados no levantamento bibliográfico realizado. FONTE: AUTORA (2021).

Quanto ao tipo de cada publicação, nota-se que a maioria das pesquisas de tese e dissertação foi encontrada na Biblioteca Digital Brasileira de Teses e Dissertações - 28 documentos, sendo 5 teses de doutorado e 23 dissertações de mestrado, em relação àquelas encontradas no Catálogo de Teses e Dissertações da CAPES - 6 teses e 10 dissertações. Já no que se refere aos artigos publicados em periódicos, 14 documentos foram encontrados no portal Scielo e 42 no Scopus (Figura 4). 


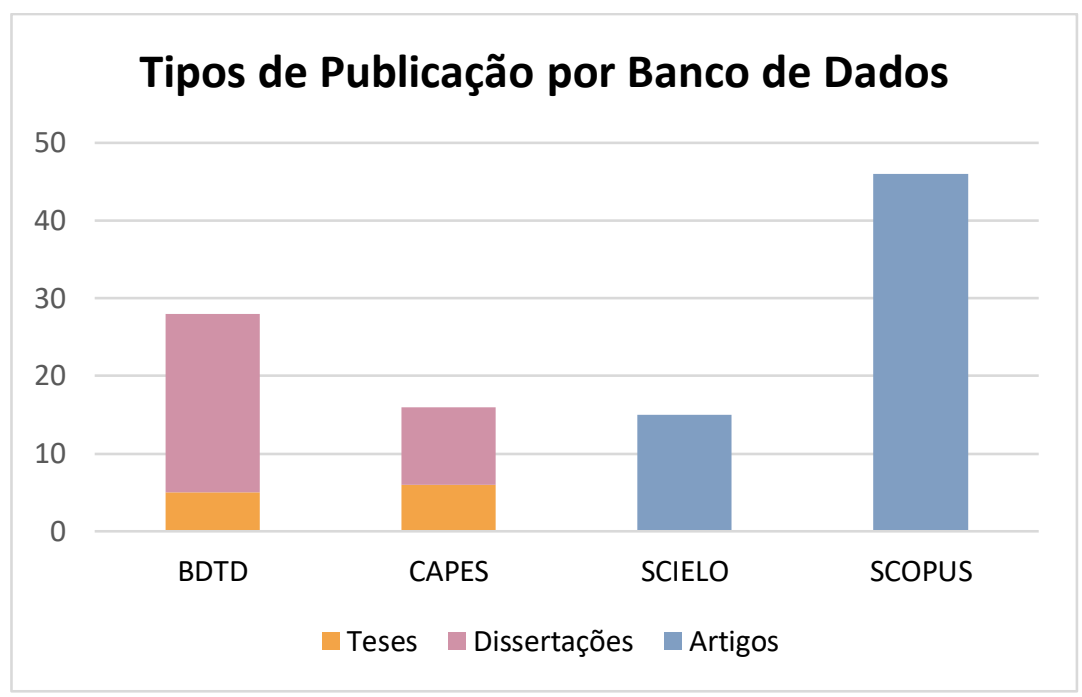

Figura 4: Distribuição de textos por tipos encontrados em cada banco de dados utilizado no levantamento bibliográfico. FONTE: AUTORA, 2021.

É importante ressaltar que pesquisas de doutorado exigem maiores investimentos, sobretudo de tempo, em relação aos outros tipos de pesquisas e publicações. Dissertações de mestrado, no entanto, são escritas durante 2 anos, em média. Já os artigos, muitas vezes escritos em parcerias ou ainda com subprodutos de pesquisas maiores, garantindo mais velocidade na escrita e publicação dos textos. Sobre a frequência e distribuição anual dessas obras (Figura 5), nota-se a constância de publicações em formato de artigos em relação às teses e dissertações. Enquanto os primeiros foram encontrados já em 2010, no cenário internacional, as últimas datam ambas de 2014. Importa destacar o progressivo aumento de pesquisas no cenário nacional entre 2016 e 2021, período em que o avanço e a atuação conservadora ganham os holofotes no plano social e político.

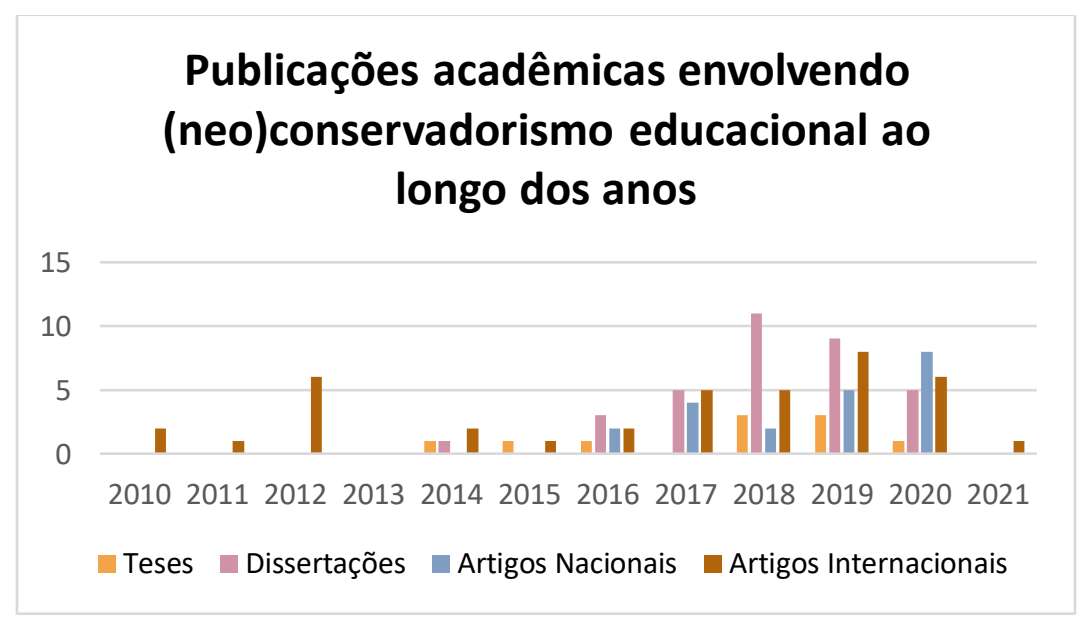

Figura 5: Distribuição anual de pesquisas relacionadas ao (neo)conservadorismo educacional ao longo do período analisado. FONTE: AUTORA (2021). 
Ao analisar a dinâmica de publicação de artigos científicos no Brasil e no mundo (Figura 6), observa-se maior número de artigos publicados no Brasil sobre o contexto brasileiro (14 encontrados no SciELO e 6 no Scopus). Já os textos publicados em outros países sobre contextos internacionais, todos referem-se a achados do Scopus. Dentre estes, Reino Unido (UK) e Estados Unidos (EUA) apresentam maior incidência de publicações. Destaco que assim como o Brasil outros países integrantes da lista abaixo experimentaram recentemente ou ainda experimentam no presente governos que variam em graus maiores ou menos de conservadorismos e populismo de direita, como é o caso do Reino Unido, Estados Unidos, Dinamarca, Áustria, Hungria e Polônia ${ }^{38}$. Vale a pena destacar que alguns textos foram publicados nos países apresentados abaixo, mas referem-se ou ao contexto global/transnacional da atuação conservadora ou, ainda, a outros países e contextos (Apêndice A).

\section{Artigos relacionados ao (neo)conservadorismo} educacional no cenário internacional

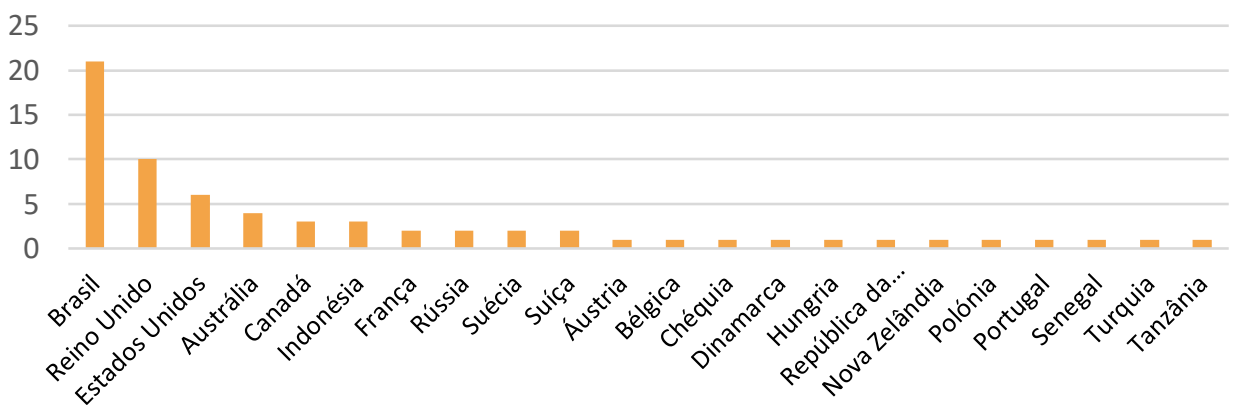

Figura 6: Publicações relacionadas ao (neo)conservadorismo educacional no cenário internacional

Descritos os padrões quantitativos da amostra, passo então a comunicação das tendências, abordagens, posições ocupadas pelo conservadorismo educacional nos textos analisados e, por fim, as contribuições dessa revisão para o trabalho que desenvolvo. A fim de apresentar os achados de maneira clara, opto por apresentálos primeiro levando em consideração o cenário nacional, seguido do contexto internacional e ao final uma síntese reflexiva de ambos. É a essa discussão que passo a seguir.

\footnotetext{
38 Os governos conservadores no cenário internacional: https://www.pragmatismopolitico.com.br/2018/11/brasil-paises-populistas-de-direita.html. Disponível em 14/02/2021.
} 


\subsection{Comunicação dos achados da revisão: tendências e abordagens do neoconservadorismo educacional no Brasil e no mundo}

A revisão realizada mostrou que, ao longo de pouco mais de uma década (2010 - 2021), as discussões envolvendo neoconservadorismo e educação teve diferentes enfoques e abordagens no Brasil ou fora dele. De maneira geral, organizo os achados em índices principais: a. posição ocupada pela educação dentro dos textos, b. temática principal da análise realizada, c. abordagem metodológica utilizada e, por último, d. reflexões trazidas pelos documentos. A elaboração destes índices se deu após sucessivas leituras interpretativas e identificação de recorrências e divergências entre todas as pesquisas integrantes do corpus revisional. Mais do que um empenho de organização, acredito que esta estrutura comunicativa permite discutir os principais pontos de interesse do levantamento realizados e tem implicações para minha própria análise sobre o tema.

De modo geral, sobre a posição ocupada pela educação dentro das discussões sobre o conservadorismo, duas maneiras de tratar a temática saltam aos olhos como principais: o analítico e o argumentativo. Em síntese, a primeira se debruça sobre o contexto educacional como principal objeto de análise, enquanto a segunda utiliza o avanço/atuação neoconservadora educacional como um componente argumentativo dentro de uma análise conjuntural maior, ou seja, a discussão do conservadorismo sobre política, a cultura e a sociedade, de maneira geral. Sobre as temáticas e abordagens metodológicas, muitas foram encontradas, entretanto análises de contextos educacionais específicos, reflexões sobre agendas políticas institucionais ou não, componentes históricos e aspectos culturais, políticos e sociais figuraram como as mais recorrentes. Para tanto, os autores recorreram aos teóricos e conceitos de diferentes áreas do conhecimento: política, sociologia, filosofia, direito e, também, educação, entre outros.

Quanto às reflexões encontradas, destaco a preocupação com instrumentalização da escola enquanto espaço de difusor de valores neoconservadores mais ou menos autoritários seja no Brasil ou em cenários internacionais. Tal percepção foi apresentada tanto por textos que olhavam para o processo educacional como foco efetivo de suas análises, quanto daqueles que o utilizavam como argumento relevante, algo que, sem dúvida, enfatiza a importância 
de investimentos em pesquisas deste porte. Realizada a síntese introdutória, passo, então, a discussão pormenorizada dos achados.

\subsubsection{O que diz o campo brasileiro}

As discussões aqui realizadas levam em consideração os 64 textos voltados para o contexto nacional (Apêndice B), sendo eles: 11 teses, 33 dissertações e 20 artigos científicos (14 oriundos do SciELO e 6 encontrados no Scopus).

\section{Posição e tratamento}

Quanto a posição ocupada pelo processo educacional nas pesquisas analisadas, 46 textos se dedicam a discutir o fenômeno do (neo)conservadorismo educacional, tratamento analítico, e 18 utilizam a temática educacional como um componente importante da argumentação que realizam sobre um contexto político maior, tratamento argumentativo.

Aquelas que tratam diretamente da questão educacional buscam olhar para a educação como um campo em constante disputa num cenário de avanço conservador (4 teses, 22 dissertações e 20 artigos). A exemplo dessa perspectiva, Almeida (2018), Toledo (2018), Pinheiro (2019) e Silva (2019) autores das quatro únicas teses que abordam de maneira direta os efeitos do conservadorismo sobre a educação, apontam que as disputas sobre os rumos educacionais, seus valores e, mesmo conteúdos, ultrapassam os muros das escolas e se inserem, respectivamente, nas redes sociais de interação, no cotidiano vivenciado por educadores que fogem dos padrões heteronormativos, marcos referenciais presentes em políticas públicas educacionais e movimento reacionários de pressão realizados sobre determinados institutos de educação. Voltarei às temáticas futuramente, mas cabe destacar a amplitude dos impactos do conservadorismo educacional sobre diferentes dimensões culturais.

Já aquelas que fazem uso da temática educacional em discussões mais amplas ( 7 teses e 11 dissertações) o fazem como linha auxiliar em reflexões sobre a ofensiva conservadora em geral. Nesse grupo discussões sobre representações, lobbies, fóruns e articulações conservadoras presentes em diferentes instâncias, tais como plenários legislativos, lideranças religiosas e redes sociais (LACERDA, 2018; PINHEIRO, 2019; SANTOS, 2019) coexistem ao lado de reflexões sobre 
conceituações gerais sobre o que de fato vem a ser o neoconservadorismo (QUADROS, 2015; LIMA; HYPÓLITO, 2019), as influências conservadoras sobre coletivos e movimentos sociais (TOITIO, 2016), por exemplo.

Quando em primeiro plano, as discussões tendem a trazer luz tanto sobre os processos específicos do microcosmo escolar, como é o caso das implicações sobre disciplinas específicas, como os panoramas envolvidos no Ensino Religioso obrigatório (SILVA, 2017), ou ainda sobre demandas maiores como discussões sobre os valores veiculados em currículos e demais políticas públicas (MOTTIN, 2019). Já quando integra os apontamentos de outras discussões, a temática educacional é mostrada como uma área de interesse, atuação e temor, dada sua capacidade de socializar, formar e estruturar a vida de sociedades por gerações (MORAIS, 2019; SANTOS, 2020). Separar os textos em tipos de abordagem me parece potente para pensar quais são usos e lugares destinados à educação em discussões sobre o neoconservadorismo. Feita a identificação das posições ocupadas, passo, então, a apresentação das temáticas encontradas pelo levantamento.

\section{Temáticas}

De modo a respeitar a separação anterior e suas especificidades, as também foram classificadas levando-as em consideração (Figura 7). Foram 4 temáticas principais observadas, 3 delas estão presentes tanto nas discussões que utilizam a educação como argumento em suas reflexões mais gerais, quanto naquelas que utilizam a temática educacional como objeto principal de sua análise, sendo elas: i. discussões sobre diversidade, ii. discussões sobre laicidade e moralização, iii. discussões sobre a natureza e atuação conservadora. Uma quarta temática relacionase apenas àquelas pesquisas voltadas diretamente à análise educacional: iv. discussões sobre educação, democracia e resistências. Um detalhe que importa ressaltar é a articulação entre as temáticas identificadas, componentes de cada uma aparece em maior ou menor grau nas outras. Logo a caracterização se deu via identificação do "carro chefe", em outras palavras, do assunto que predomina em relação aos demais.

As discussões gerais sobre diversidade (Apêndice B) abordam percepções sobre conceitos como homofobia e homossexualidade (FELICISSIMO, 2014), redes de significado presentes em exposições artísticas e conteúdos 
cinematográficos (ZANELLA, 2020; PINHEIRO, 2018) e impactos de políticas públicas neoliberais sobre comunidades LGBT (TOITIO, 2016), entre outras. Nessas discussões, a educação figura como uma força social que historicamente perpetua desigualdades e preconceitos, mas que contêm grande potencial de inclusão pluralista. Essa mesma dinâmica é apontada pelos textos que discutem a diversidade na educação. A preocupação com discussões que abordem os gêneros e as sexualidades de maneira respeitosa e plural nos currículos escolares mobilizou agentes civis, políticos e lideranças religiosas em Cruzadas contra a educação sexual (SANTIAGO, 2016; SILVA, 2016; ROSENO, 2017; SANTOS, 2017; ALMEIDA, 2018; HONORATO, 2018; CAMARGO, 2019; PINHEIRO, 2019; SONNETTI; GARCIA, 2020).

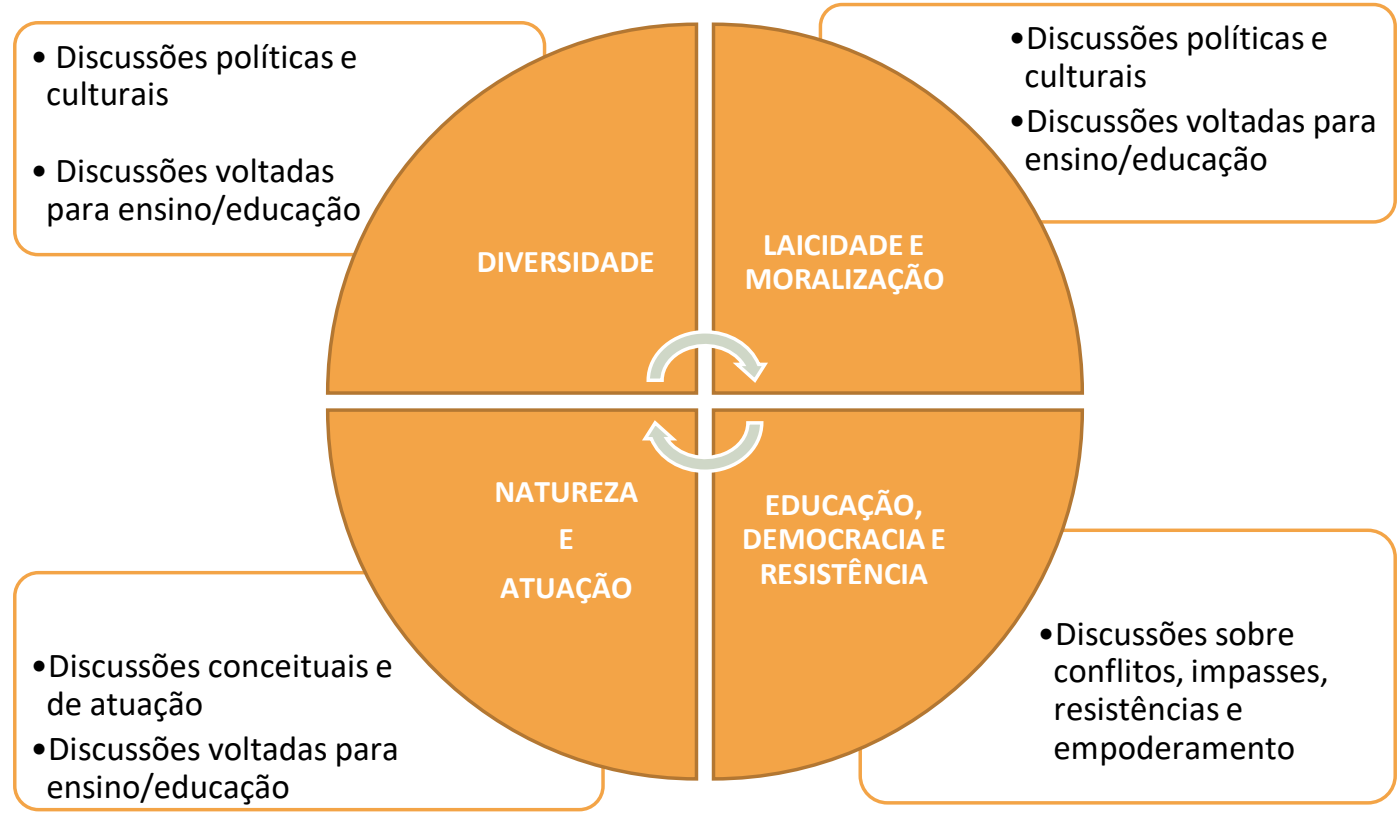

Figura 7: Temáticas encontradas no levantamento bibliográfico sobre o cenário brasileiro. FONTE: AUTORA (2021).

As discussões sobre laicidade e moralização guardam algumas relações com as discussões sobre diversidade, dada a tendência das lideranças religiosas, sobretudo evangélicas neopentecostais, em projetar suas crenças, ideologias e preconceitos sobre todos que, segundo suas percepções, apresentam modos de vida desviantes. Além das discussões sobre papéis adequados de gênero e projeção de fobias religiosas no plano político e social em geral, a ascensão de lideranças religiosas e a capacidade de mobilizar recursos e paixões por parte desses sujeitos, 
assim como reflexões sobre a inserção religiosa na política institucional também foram encontradas com recorrência (MOREIRA, 2014; KOREN, 2016; VIEIRA, 2017; GOMES, 2019; MORAIS, 2019).

Nas pesquisas diretamente ligadas à educação, discussões sobre "ideologia de gênero" nos currículos (SILVA, 2016; COELHO, 2017; MOUTTIN, 2019), "ensino religioso" como componente curricular disputado por agentes conservadores (SELLES, 2016; SILVA, 2017; CARVALHO; SÍVORI, 2017), "equivalência entre conteúdos científicos e dogmas religiosos" (SELLES; DORVILLÉ; PONTUAL, 2016; CALDEIRA, 2018), “conservadorismos morais nas políticas públicas educacionais" (JACÓ, 2019) e "ativismo pró homeschooling" (CECCHETTI; GOUVEIA, 2020) refletem sobre os limites entre público e privado, laicidade e moralização dos afetos, comportamentos e corpos.

As discussões encontradas no eixo natureza e atuação conservadora em síntese procuram mapear as origens do conservadorismo, suas articulações e agendas (QUADROS, 2015; LACERDA, 2018). Essas pesquisas buscam também apontar movimentos específicos no plano político e social orquestrados por sujeitos alinhados às pautas conservadoras historicamente reconhecidas: o neoliberalismo como política econômica, os valores religiosos como orientação moral maior, as investidas, a demonização do outro e o acirramento de antagonismos políticos e sociais diversos, entre outros (DIAS, 2018; MAYER, 2018; SANTOS, 2019).

Quando voltadas para a educação, essas abordagens se repetem, porém com o objetivo maior de construir entendimentos sobre como as ações em curso em cenários mais amplos influenciam a escola, a universidade, enfim, o processo educacional em seus diferentes níveis. Atuações parlamentares pró ensino religioso, educação domiciliar, discussões em fóruns interativos sobre doutrinação escolar nas redes sociais, programas que exigem a censura de conteúdos e pedem neutralidade docente, como é o caso do Escola sem Partido, investidas neoliberais e gerencialistas sobre o processo educacional integram esse bloco temático (VEIGA, 2017; ARAGUSUKU; LOPES, 2018; FREIRE, 2018; LIRA, 2018; MEDEIROS, 2018; MOREIRA，2018; AVELLAR，2019; LIMA; HYPÓLITTO, 2019; OLIVEIRA FILHO, 2019; SEVERO et al, 2019; SILVA, 2019; CAMPOS, 2020; EDITORES DA REVISTA EDUCAÇÃO E SOCIEDADE, 2020; LIMA, 2020; PALÚ; PETRY, 2020; PERONI, 2020; PERONI; LIMA, 2020; PERONI; OLIVEIRA, 2020). 
Por fim, as discussões sobre democracia e resistência na educação procuram ir além de tudo o que foi discutido até então, elas procuram refletir sobre possibilidade de enfrentamento, resistências e empoderamento frente a gama de ofensivas neoconservadoras sobre a educação nacional. As pesquisas discutem as funções e atribuições educacionais em contextos de ameaça antidemocrática neoconservadora, as atitudes de coletivos estudantis e lutas cotidianas de educadores e educadoras que precisam lidar com as projeções morais e políticas no chão da escola, entre outras (SHOR et al, 2016; GOMES, 2018; LEME, 2018; ALBUQUERQUE, 2019; CARVALHO, 2019; SOUZA; MENDONÇA, 2019; SANTOS, 2020; SILVA, 2020).

\section{Abordagem Metodológica}

Identificar as abordagens metodológicas empregadas pelas pesquisas permite compreender os principais objetos e sujeitos utilizados pelos autores como fonte de dados, bem como as formas como estes são tratados. A meu ver, esse saber auxilia o mapeamento das práticas analíticas recorrentes no campo e sinaliza quais são as maneiras mais profícuas de encontrar, tratar e refletir as informações encontradas. Assim, segundo o levantamento realizado, é possível afirmar que a abordagem qualitativa é predominante nos estudos sobre (neo)conservadorismo, seja no plano político e cultural em geral, ou nos estudos sobre o universo educacional, todos os trabalhos a utilizam.

Quanto ao corpus, a pesquisa documental (entendida como utilização de fontes primárias de dados, ou seja, de documentos escritos ou não em seu formato original, não tratado cientificamente) seja sozinha, ou em associação a pesquisa bibliográfica (materiais elaborados e/ou tratados cientificamente, tais como levantamentos, artigos e etc.), figura como o tipo mais frequente entre os achados tanto gerais, quanto diretamente ligados à educação.

Essas pesquisas buscaram compreender sentidos, articulações, atuações e perspectivas conservadoras em:

a. Políticas públicas educacionais nacionais, estaduais ou mesmo municipais (FELICISSÍMO, 2014; SANTOS, 2017; VEIGA, 2017; ALBUQUERQUE, 2018; ARAGUSUKO; LOPES, 2018; GOMES, 2018; HONORATO, 2018; MEDEIROS, 2018; MOREIRA, 2018; JACÓ, 2019; OLIVEIRA FILHO, 
2019; PINHEIRO, 2019; CAMPOS, 2020; SANTOS, 2020, SONETTI; GARCIA, 2020).

b. Projetos de lei, discursos e votações em plenários da Câmara Federal de Deputados envolvendo valores religiosos, morais e perspectivas corretas de composição familiar, gênero e afins (MOREIRA, 2014; DIAS, 2017; COELHO, 2017; LUNA, 2017; ROSENO, 2017; SANTOS, 2017; QUADROS, 2015; LACERDA， 2018; LIMA; HYPÓLITO, 2019; OLIVEIRA, 2019).

c. Currículos e espaços educacionais (SELLES, DORVILLÉ, PONTUAL, 2016; CARVALHO; SÍVORI, 2017; SILVA, 2017; SILVA, 2019)

d. Filmes, revistas, produções áudio visuais e exposições artísticas consideradas transgressoras (SANTIAGO, 2016; CALDEIRA, 2018; REZENDE, 2018; CARVALHO, 2019; ZANELLA, 2020)

e. redes sociais, materiais de divulgação e sermões religiosos (KOREN, 2016; ALMEIDA, 2018; CUNHA, 2019; MORAIS, 2019; MOUTTIN, 2019 OLIVEIRA, 2019; SEVERO; GONÇALVES; ESTRADA, 2019; VIEIRA, 2020).

Também foram encontradas observações participantes associadas à entrevistas em ambiente escolar de educação infantil (CAMARGO, 2019), entrevistas com gestores escolares e professores de diferentes disciplinas (TOLEDO, 2018; PERONI; OLIVEIRA, 2020; SANTOS, 2020), movimentos sociais LGBT e estudantis (TOITIO, 2016; LEME, 2018 ), análises de questionários respondidos por lideranças religiosas sobre finalidades escolares (ALVES, 2020), análise de crenças de estudantes de medicina sobre educação sexual via questionário (GRECCO, 2019) e reflexões teórico-conceituais sobre as implicações da ofensiva neoconservadora e os limites entre público e privado na política e na educação (SELLES, 2016; SHOR et al, 2016; EDITORES DA REVISTA EDUCAÇÃO \& SOCIEDADE, 2018; SOUZA; SILVA, 2018; MENDONÇA, 2020; PALÚ; PETRY, 2020; PERONI, 2020; PERONI; LIMA, 2020; PERONI; OLIVEIRA, 2020).

Em geral, as pesquisas usaram referenciais teóricos distintos. Conceitos oriundos das Ciências Políticas, Direito, Sociologia, Antropologia e Educação, entre outras áreas, eram articulados e mobilizados de acordo com a temática em destaque. A amplitude de pressupostos teóricos conjugados somados à gama de 
abordagens metodológicas distintas indicam a complexidade que caracteriza o fenômeno entendido como conservadorismo ou neoconservadorismo. No que se refere à educação, destaco o esforço das pesquisas em documentar práticas, compreender estratégias e produzir reflexões conjunturais sólidas e mais capazes de embasar ações de resistência e enfrentamento.

\section{Reflexões e Contribuições}

As principais reflexões apresentadas pelos trabalhos analisados podem ser divididas em três grandes eixos: i. o entendimento de que o neoconservadorismo não é um fenômeno social passageiro e baixas implicações para o presente e futuro da sociedade, ii. a identificação do componente religioso, sobretudo cristão neopentecostal, como um dos principais catalizadores da atuação conservadora e iii. a compreensão de que a educação ocupa um lugar singular num contexto conservador em construção ou plenamente estabelecido

Quanto ao primeiro eixo, as pesquisas que abordaram a ofensiva conservadora em termos mais gerais foram categóricas quanto a capacidade de espraiamento e capilaridade do conservadorismo nas diferentes dimensões da vida em sociedade. Seja por inspiração direta, ressurgimentos ou adaptações, o neoconservadorismo brasileiro é visto como herdeiro de movimentos conservadores originários de outros países, especialmente dos Estados Unidos da América (QUADROS, 2015; LACERDA, 2018; PINHEIRO, 2019; SANTOS, 2019).

Sobre a importância do componente cristão/evangélico é destacada tanto por sua atuação institucional (sujeitos eleitos para diferentes cargos ou ocupantes de cargos públicos relevantes nas diferentes esferas do poder político), quanto através de articulações e organizações civis (grupos de empresários, ativistas religiosos, lobistas pró-armamento, entre outros). A suposta universalidade dos valores cristãos, o efeito moralizante de suas defesas sobre os tipos corretos de família, gênero, comportamento e afeto, sua influência no apagamento dos limites entre público e privado, sua tendência a mobilizar paixões e negações que "demonizam" saberes científicos, são apontados como aspectos relevantes da atuação religiosa tantos nos textos que analisam contextos mais gerais (MOREIRA, 2014; KOREN, 2016; VIEIRA, 2017; GOMES, 2019; MORAIS, 2019), quanto naqueles voltados à educação especificamente (SELLES, 2016; SELLES; DORVILLÉ; PONTUAL, 
2016; SILVA, 2016; SILVA, 2017; CARVALHO; SÍVORI, 2017; COELHO, 2017; CALDEIRA, 2018; JACÓ, 2019; MOUTTIN, 2019; CECCHETTI; GOUVEIA, 2020).

Por fim, quanto a preocupação com a transformação da escola da escola em um espaço difusor de valores neoconservadores é enfatizada tanto em textos gerais, quanto naqueles voltados diretamente à educação. A ideia de uma "guerra cultural" alimentada por fobias religiosas, pânicos morais e antagonismos políticos surge de maneira mais ou menos direta em quase todos os textos e convidam a pensar sobre os arranjos (anti)democráticos que vivemos atualmente e sobre o tipo de educação que queremos preservar (VEIGA, 2017; ARAGUSUKU; LOPES, 2018; FREIRE, 2018; LIRA, 2018; MEDEIROS, 2018; MOREIRA, 2018; AVELLAR, 2019; OLIVEIRA FILHO, 2019; SEVERO et al, 2019; SILVA, 2019; CAMPOS, 2020; EDITORES DA REVISTA EDUCAÇÃO E SOCIEDADE, 2020; LIMA, 2020; PALÚ; PETRY, 2020; PERONI, 2020; PERONI; LIMA, 2020; PERONI; OLIVEIRA, 2020); GOMES, 2018; LEME, 2018; ALBUQUERQUE, 2019; CARVALHO, 2019; SOUZA; MENDONÇA, 2019; SANTOS, 2020; SILVA, 2020).

\section{O que diz o cenário internacional}

\section{Posição e Temáticas}

No que se refere aos textos publicados em periódicos estrangeiros, das 36 pesquisas encontradas no Scopus 07 utilizam a educação como linha auxiliar em suas discussões políticas e culturais mais amplas, enquanto todas as demais 29 investigações centralizam suas reflexões sobre o processo educacional. Sobre as temáticas encontradas (Figura 8), é possível observar certa semelhança entre aquelas encontradas no contexto nacional. Nas pesquisas que utilizam a educação como parte de um contexto maior, 3 buscam discutir questões relacionadas à diversidade sexual. É interessante observar que essas reflexões evidenciam a importância do componente religioso em suas análises, tal como acontece no cenário brasileiro. 


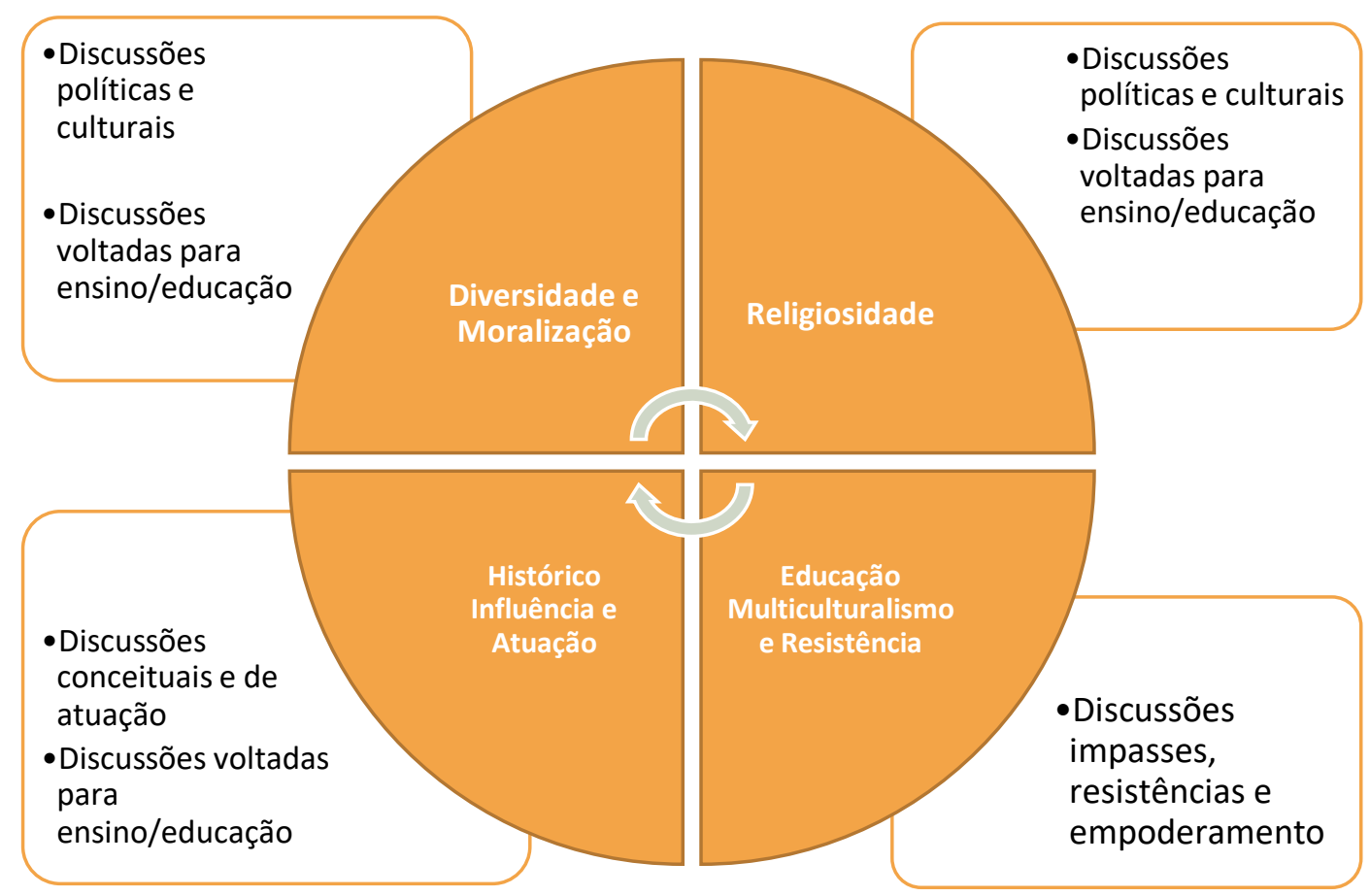

Figura 8: Temáticas encontradas no levantamento bibliográfico sobre o cenário internacional. FONTE: AUTORA (2021).

Em sua discussão sobre a agenda anti-gênero que abrange países de todo o mundo, Korolcsuk e Graff (2018) apontam que é na educação que lideranças religiosas e agentes conservadores buscam criar plataformas de atuação. Já Aune e Guest (2019) aponta que as percepções e crenças sobre gênero e sexualidade podem apresentar maior tendência ao preconceito e ao conservadorismo entre fiéis religiosos que frequentam ativamente suas igrejas, paróquias e templos sagrados, independentemente de seu grau de instrução ou formação educacional. Por fim, Pattilo-Lunt (2021) mergulhou na análise de uma revista feita para universitários americanos da década de 1960, nos EUA, sobre o tipo ideal de ética e comportamento sexual a ser adotada por jovens conservadores e cristãosconservadores.

Nas pesquisas que tratavam a educação de maneira analítica também foram 3 aquelas relacionadas à discussão sobre diversidade. Todos os trabalhos buscaram discutir a educação sexual a partir de diferentes perspectivas. Cavazos-Reng et al (2012), procuraram avaliar o impacto da educação sexual nos índices de natalidade de diferentes estados dos EUA; CHAU et al (2016) discutiram o tipo de educação sexual oferecido no Senegal e, por fim, Cardoso e Mowlo (2017), analisaram a realização de atividades de educação sexual por Organizações Não Governamentais 
(ONGs) na Tanzânia. Apesar dos diferentes contextos alguns diálogos podem ser travados a partir dos resultados trazidos por eles. Segundo Cavazos-Reng (2012) e colaborados, a educação sexual pode ter pouco ou nenhum efeito sobre os índices de natalidade quando realizados a partir de uma abordagem engessada, pouco esclarecedora e carregada de conservadorismos. Nesse sentido, Chau et al (2016) apontam que, mesmo com as barreiras e conservadorismos socioculturais relacionados ao tema, ao articular programas claros e cientificamente orientados, voltados para a vida reprodutiva dos jovens e associados a instituições civis e governamentais empenhados em garantir uma educação de qualidade, é possível fazer diferença mesmo em países culturalmente conservadores e de baixa e média renda populacional. Na Tanzânia, Cardoso e Mowlo (2017) mostram que o currículo educacional é carregado de silenciamentos, conservadorismos morais, assim como as trocas em sala de aula carregadas de vergonha e acanhamentos tanto por parte de professores, quanto dos alunos. Em sua pesquisa, esses autores mostram como ONGs buscam oferecer práticas e formações em educação sexual aos jovens em idade escolar, a fim de oferta-lhes conhecimento e espaço para tirar dúvidas sobre o assunto.

Nas discussões gerais sobre religiosidade, ambas as pesquisas encontradas mostram a importância do credo religioso, da frequência de culto, leitura bíblica e compromisso religioso com a negação parcial ou completa de conteúdos e conhecimentos científicos como a evolução biológica e as mudanças climáticas no Reino Unido, respectivamente Village e Baker (2018) e Eckulund et al (2017). A formação educacional e o grau de instrução também são apontados como pouco eficazes na diminuição da versão ou negacionismo promovido por fobias religiosas e posicionamentos políticos entre sujeitos assíduos e comprometidos com suas religiões.

Já nas pesquisas que tratam analiticamente o processo educacional foram 4 os trabalhos encontrados relacionados ao tema religiosidade, 3 deles voltados para e educação religiosa da Indonésia (ZUHDI, 2018; WIJAYA, MULYA; ADITOMO, 2019; LAKSAN; WOOD, 2019). A saber, a Indonésia é um país com 90\% de sua população mulçumana e historicamente adepta de uma prática moderada do Islã, ou seja, não contrária a outras religiões em seu território, com exceção da província semiautônoma de Aceh que é regida pela Sharia, lei 
islâmica ${ }^{39}$. Nas três investigações os autores apontam que a disciplina de educação religiosa é vista por professores e alunos do Ensino Médio como um lugar para discutir sobre outras religiões e exercitar a cultura da tolerância religiosa. Entretanto, os autores também apontam a crescente onda de conservadorismo religioso político e educacional mais severo e afastado das práticas de cultura da paz mencionada pelos entrevistados.

Já a pesquisa de Simmie e Edling (2016), buscou comparar o tipo de ideologia educacional predominante em dois países com diferentes configurações político religiosa: a secular Suécia e a não secular República da Irlanda. Enquanto a Suécia conjuga separação entre igreja e Estado e baixa adesão populacional à moral religiosa, a religião teve e ainda tem fator preponderante na consolidação da identidade política e cultural irlandesa. Apesar das diferenças culturais, o estudo mostra uma virada ideológica nas políticas públicas educacionais, sobretudo naquelas voltadas para a formação de professores, a partir da década de 1960. Os discursos e valores passaram a sofrer forte influência do mercado econômico e os valores morais conservadores, evidenciando $\mathrm{o}$ avanço de ofensivas neoconservadoras mesmo sobre territórios considerados seculares ao longo da história.

Quanto ao bloco temático histórico, influência e atuação conservadora, assim intitulado pela relação intrínseca entre esses conceitos, Shepperd (2017) e Kinder e Binder (2020) mostram formas distintas dessa capacidade de capilaridade e mobilização conservadora. Enquanto a primeira pesquisa disserta sobre a baixa representatividade de gestoras em unidades de Ensino Superior e atribuem essa realidade ao conservadorismo cultural, político e econômico que diminuem as possibilidades de formação feminina para atuação e liderança no mercado de trabalho na Europa, a segunda aponta como o conservadorismo representado pela adesão à política de Donald Trump, então presidente norte americano, adentra campus universitários nos Estados Unidos.

Nas discussões diretamente ligadas à educação, esse bloco temático, foi o mais frequente entre os achados do levantamento bibliográfico, somando ao todo 14 pesquisas. É interessante observar que a grande maioria das pesquisas apontam a influência do componente econômico dentro desse eixo nos diferentes contextos

\footnotetext{
${ }^{39}$ Informações sobre o conservadorismo religioso na Indonésia: https://istoe.com.br/indonesiaproibe-que-hijab-seja-obrigatorio-nas-escolas/. Disponível em 15/03/2021.
} 
culturais analisados (Austrália: CLARK (2012); DOHERTY et al (2012); PEACOCOK (2012); PITMAN (2020). Dinamarca: DANIELSEN et al (2017). França: KAHN (2019); MOLE (2019). Grã Bretanha e Reino Unido: JONES (2014); BAGLEY; BEACH (2015); JOPLING (2019), MCINTYRE; YOENS; STEVENSON, (2019); NEWMANN et al (2020). Iugoslávia: TROCH, (2010). Rússia: SHAPOSHNIKOV (2020) e Turquia: KUÇUKER (2018)). As influências morais e militaristas são apontadas como integrantes desse eixo, ocupam uma posição de menor destaque nos estudos mencionados compondo o quadro geral de agentes atuantes e constituições históricas. Porém, são os impactos e implicações neoliberais economicistas que ganham maior destaque.

Apesar do destaque dos impactos neoliberais na educação, discussões sobre agendas transnacionais conservadoras também foram encontradas. Nelas os componentes econômicos, morais, religiosos, anti-gênero, pró-homeschooling e, muitas vezes pró-disciplina militar na educação, estão articulados em reflexões que ultrapassam os limites históricos e geográficos (BENCZE, 2010; BENCZE; CARTER, 2011; NETO; DAMASCENO, 2020; PERMOSER; STOECKEL, 2020).

Por fim, uma temática diretamente relacionada à educação é a educação, multiculturalismo e resistências, que conta com três estudos: a discussão sobre os embates e potenciais da inclusão da diversidade étnica e cultural nos currículos educacionais brasileiros (AKKARI, 2012), as reflexões sobre a necessidade de formação para a autonomia e a convivência multicultural nos EUA (KELLER; KELLER, 2014) e no mundo (SHANNON-BAKER, 2018). Estes trabalhos chamam atenção para a diversidade, os direitos humanos e perspectivas educacionais mais plurais. Longe de oferecer respostas prontas, essas pesquisas buscam apontar iniciativas, conceitos teóricos e análises conjunturais que podem ajudar a pensar a educação em termos emancipatórios.

\section{Abordagens Metodológicas e Reflexões}

Sobre as abordagens metodológicas, diferentemente do cenário brasileiro em que as pesquisas qualitativas predominavam, as pesquisas internacionais apostam na articulação entre análises quantitativas e qualitativas de dados oficiais de censos, relatórios de agências internacionais e Surveys longitudinais. Esse tipo de tendência macro analítica pode apontar certo amadurecimento do campo, visto 
que os debates sobre estes temas já ocorrem no cenário externo há décadas, ao contrário do Brasil. É possível, no entanto, apontar a existência de abordagens teórico-conceituais (BENCZE, 2010; BENCZE; CARTER, 2011; KOROLCSUK; GRAFF，2011; AKKARI，2012; CLARK，2012; JONES，2014; KELLER; KELLER, 2014; SHANNON-BAKER, 2018), entrevistas com números de participantes variáveis (KUÇUKER, 2018; ZUHDI, 18; MCINTIRE; YOUESN; STEVENSON, 2019), observações participantes somadas a entrevistas e atividades pré/ pós participação (JOPLING, 2019; WIJAYA; MULYA; ADITOMO, 2019) e análises documentais propriamente ditas (KAHN, 2019; NETO; DAMASCENO, 2019).

Assim como no cenário brasileiro, os autores articulam conceitos oriundos de áreas do conhecimento distintas, tais como Ciências das Religiões, Sociologia, Direito, História, Serviço Social, Economia, Educação, entre outros. Reitero o entendimento de que a gama de conceitos e teorias mobilizadas para discutir o fenômeno neoconservador indica a complexidade das discussões sobre ele.

Por fim, no que se refere às reflexões e contribuições trazidas pelo levantamento em questão, podemos destacar: i. a percepção de que o componente religioso pode diminuir ou anular a cultura e a formação educacional, ii. a identificação do componente econômico como o aspecto de maior relevância nas discussões sobre influência do neoconservadorismo nas políticas públicas educacionais e iii. a compreensão de que para crescimento e amadurecimento do campo mais pesquisas longitudinais e articulando dados quanti-qualitativos devem ser realizados, discutidos e socializados.

\section{Síntese}

A realização desse levantamento bibliográfico foi igualmente desafiadora e prazerosa. As diferentes bases de dados, a operacionalização do levantamento, indexação dos achados e discussão dos resultados em alguns momentos se mostrou difícil e exaustiva, mas, ao final, mostrou-se satisfatória levando em conta todas as circunstâncias em que foi realizada. Os achados encontrados nos cenários nacional e internacional apontam a posição ocupada pela educação como importantes nas discussões sobre o neoconservadorismo. Seja como espaço em disputa ou como vetor de valores, a escola básica e a educação superior surgem como espaços importantes dentro dessas reflexões. 
Um segundo componente interessante são as temáticas. Apesar de apresentar diferenças em suas classificações, as temáticas nacionais e internacionais evidenciam elementos semelhantes como relevantes: a diversidade sexual/cultural, a moralidade religiosa, os valores tradicionais, a atuação civil e institucional no avanço conservador em diferentes dimensões sociais, o apagamento dos limites entre público e privado, e a necessidade de reposicionamento da educação como lugar de enfrentamento, empoderamento e resistência.

No que se refere às metodologias aplicadas, o levantamento destacou o investimento qualitativo e quanti-qualitativo em análises que vão desde o nível micro (o chão da escola no Brasil ou no Reino Unido) e macro (mapeamento de ações, percepções, atuações e fins em diferentes contextos e países). Ainda sobre a abordagem teórico-metodológica, mais uma vez destaco a variedade de articulações conceituais encontrada, as quais não tive fôlego para debater de maneira pormenorizada. A complexidade que envolve o conservadorismo político e suas implicações para a educação nos diferentes contextos culturais e nacionais exige um trabalho de dedicação exclusivo que pretendo me debruçar ao final deste trabalho de doutoramento.

Tendo esses destaques em consideração e as reflexões a partir dos referenciais teóricos discutidos anteriormente, passo, então, à apresentação da metodologia empregada na análise do meu próprio corpus de análise. 


\section{Metodologia}

Neste estudo busco analisar o avanço do neoconservadorismo educacional em curso no Brasil. Para tanto, procurei me apoiar numa perspectiva qualitativa de investigação. Tal opção encontra suporte na compreensão de que tal abordagem, ao dispor de práticas metodológicas materiais interpretativas, permite a apreensão da realidade investigada em um nível mais profundo que o meramente observado (MINAYO et al, 1994). Possibilitando, assim, a construção de novos conhecimentos sobre os fenômenos estudados e a formulação de novas indagações sobre estes, algo que potencializa a ampliação dos limites de conhecimento existentes até então (DENZIN; LINCON, 2006).

Resgato, para melhor compreensão dos procedimentos metodológicos empregados nesta investigação, as questões norteadoras: "Quais as agendas, agentes e discursos relacionados à lógica conservadora brasileira na educação? Quem são estes indivíduos? Que valores e objetivos os movem? Qual é o lugar ocupado pela religião nesse contexto político e social?”. Dessa forma a pesquisa que aqui apresento pode ser considerada uma análise temática de documentos, para tanto utilizo o referencial ofertado por Laurence Bardin em Análise de Conteúdo (2016), discutido a diante.

\subsection{Percurso metodológico: entre o pretendido e o realizado}

Conforme exposto na estrutura metodológica que abre este trabalho, esta pesquisa precisou sofrer uma grande reformulação após a chegada da pandemia COVID-19 ao Brasil. Se antes a investigação pretendia olhar para as dinâmicas estabelecidas no microcosmo escolar e previa a utilização de questionários, períodos de observação e entrevistas com docentes, gestores e alunos, com a quarentena sanitária e a suspensão das aulas presenciais, precisei redesenhar não só o percurso metodológico, mas sim a pesquisa como um todo. A fim de manter a ênfase investigativa na agência neoconservadora educacional, redirecionei a pesquisa para o nível das políticas públicas. Destaco, no entanto, que essa não é uma tese de análise de políticas públicas implementadas ou em fase de implementação. Ao contrário, procuro olhar para documentos, projetos de lei, 
discursos e afins, em busca de marcas da agenda neoconservadora em seus textos e contextos.

Esclarecidas as particularidades contextuais em que se insere esta tese, passo a apresentação do corpus da análise. O conjunto de dados analisados nessa pesquisa é composto por Projetos de Lei propostos na Câmara dos Deputados, manifestos produzidos por frentes parlamentares, discursos proferidos pelos representantes políticos e associações, e, por fim, contextos e trechos de documentos oficiais norteadores do currículo e do funcionamento escolar, tais como a BNCC, Plano Nacional de Educação - PNE, e a Reforma do Ensino Médio (Figura 9).

\section{Neoconservadorismo Brasileiro na Educação}

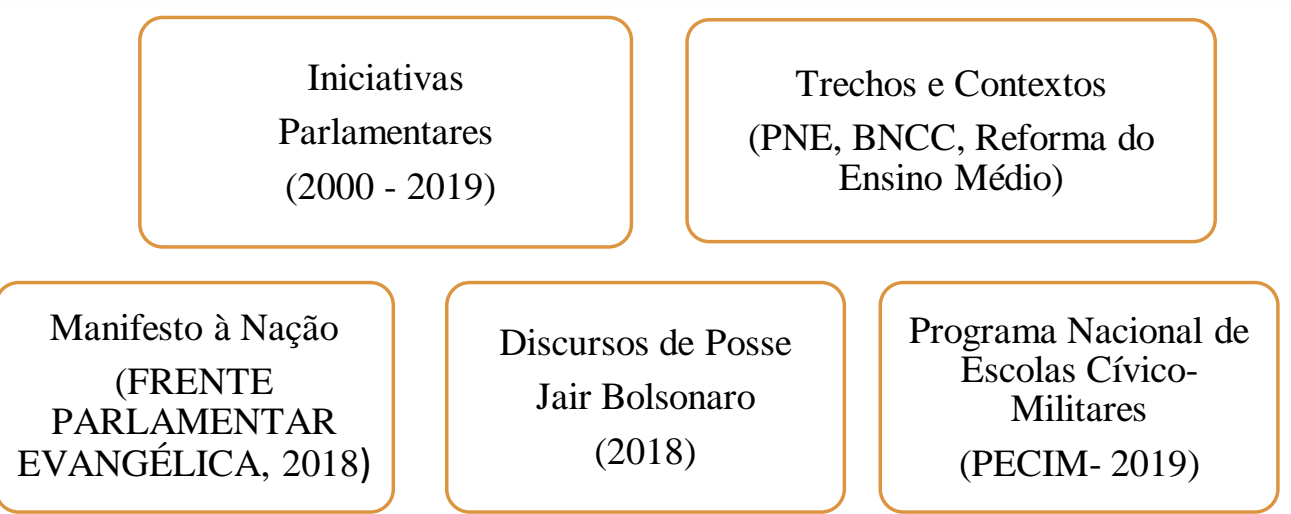

Figura 9: Composição do corpus de análise

A partir da análise destes materiais, busco apontar convergências e divergências, agendas e agentes, valores e argumentos que sustentam o ativismo conservador na educação brasileira. A escolha deste tipo de documentos se deu por motivos que se complementam: i) a análise de projetos de lei permite ver a atuação parlamentar em torno do conservadorismo educacional (indivíduos, partidos, grau de associações entre proponentes e demais aspectos relacionados), ii) análise de discursos e manifestos favorece a compreensão dos argumentos e valores mobilizados, e, iii) a análise de trechos de projetos/medidas já transformados em lei, e seus contextos, permite ver os valores por trás de uma política pública em andamento, as negociações e as presentes em seus textos. Por entender que a seleção deste material de análise merece maiores explicações, passo, então, a apresentação de cada etapa percorrida nesse processo. 


\subsection{Levantamento das iniciativas parlamentares: a construção da base de dados}

Neste trabalho identifico e analiso projetos de lei e projetos de leis complementares que apresentam caráter conservador e se debruçam sobre a educação nacional. Para tanto utilizei uma base de dados com os referidos materiais construída no âmbito do grupo de pesquisa ao qual estou vinculada, o Diversias (Grupo de Estudos em Educação, Diversidade e Controvérsias). Sediado na Pontifícia Universidade Católica do Rio de Janeiro - PUC-Rio, e coordenado pelo professor Pedro Teixeira, o Diversias desenvolve pesquisas sobre diferenças culturais, educação e controvérsias. $\mathrm{O}$ avanço do neoconservadorismo na educação brasileira é uma temática que interessa ao grupo e atravessa diferentes pesquisas de mestrado e doutorado em andamento. Nesse contexto, em virtude da suspensão de atividades presenciais de pesquisa, a tarefa de construir uma base de dados com projetos de lei surgiu tanto como uma forma de manter o grupo de pesquisa ativo e engajado, como também uma possibilidade de verificarmos a materialização (ou não) das leituras e discussões teórica que estivemos fazendo até então.

Um subgrupo composto por seis estudantes ${ }^{40}$ que possuíam maior interesse pela temática foi criado e as áreas de interesse contaram como fatores importantes na determinação dos tópicos a serem pesquisados, bem como a leitura do livro $O$ novo conservadorismo brasileiro (LACERDA, 2019). Os temas e as palavras-chave pesquisadas no mecanismo de busca do endereço eletrônico da Câmara dos Deputados ${ }^{41}$ podem ser observados na Figura 10. É importante mencionar que além dos Projetos de Lei "comuns" (PL), foram incluídos os Projetos de Lei Complementar (PLC), Projeto de Decreto do Legislativo (PDL), Projeto de Decreto da Câmara ${ }^{42}$ Proposta de Emenda à Constituição $(P E C)^{43}$ e Indicações da Câmara

\footnotetext{
40 Atuaram na construção da base de dados: Adrian Henriques, Allan Silva, Caio Garcia, Caroline Maciel, Ingrid Gomes, Patrícia Barros com a supervisão de Pedro Teixeira.

${ }^{41} \mathrm{O}$ mecanismo de busca da Câmara dos Deputados pode ser encontrado no seguinte endereço eletrônico: https://www.camara.leg.br/busca-portal/proposicoes/pesquisa-simplificada . Disponível em 28/09/2020.

42 Os PLC requerem maioria absoluta para sua aprovação, ou seja, metade mais um do número total de deputados. Já os PDL têm poder de sustar decisões do Poder Executivo. Os PDC são proposições que visam regular matérias de competência exclusiva do Legislativo, sem a sanção do Presidente da República Disponível em: https://www.congressonacional.leg.br/legislacao-e-publicacoes/glossario Acesso em: 16/11/2020.

43 Uma PEC é utilizada com o objetivo de mudar algo que já consta na Constituição Federal. Disponível em: http://www.senado.gov.br/noticias/agencia/quadros/qd_374.html. Acesso em: 28/09/2020
} 
(INC). Sob minha responsabilidade ficaram as pesquisas relacionadas ao criacionismo, à militarização do ambiente escolar e à educação domiciliar/homeschooling.
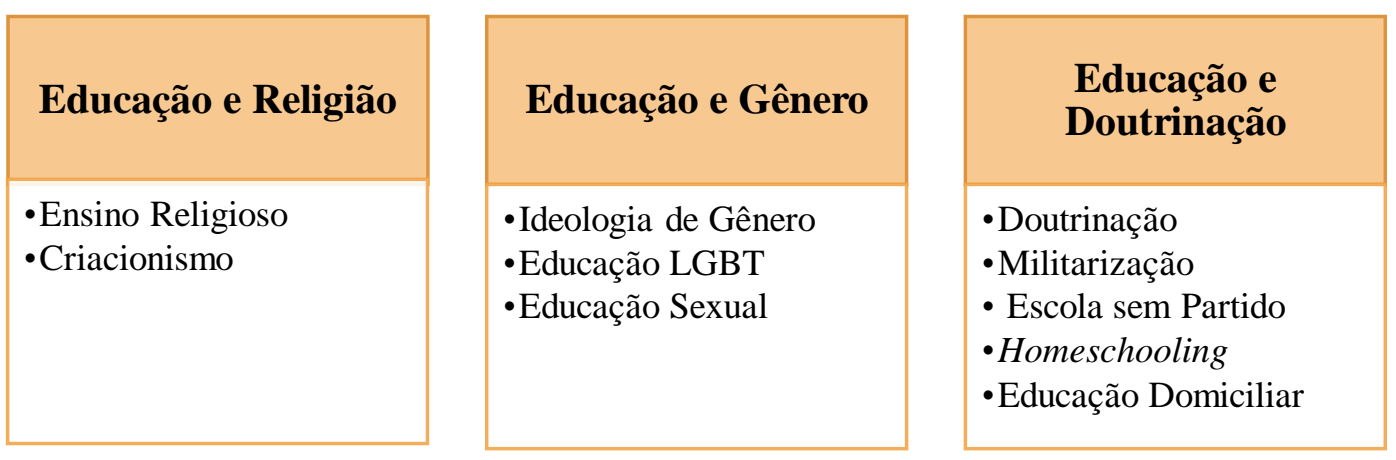

Figura 10: Temas gerais e palavras-chaves pesquisados no mecanismo de busca do endereço eletrônico da Câmara dos Deputados.

O universo inicial das inciativas encontradas contava com aproximadamente 181 documentos em abril de 2020, após a exclusão de duplicatas e projetos que traziam um ou alguns dos termos procurados na pesquisa, mas que não se referiam de textos voltados para a educação, o resultado foi de 153 iniciativas parlamentares para o período de 2001 a 2020, consolidado em outubro de 2020 em virtude do segundo exame de qualificação desta pesquisa. Em uma etapa de revisita aos dados através de novas pesquisas às árvores de apensados dos documentos, em fevereiro de 2021, o número total que compõem o corpus desta pesquisa passou a ser 187 iniciativas parlamentares.

Em uma etapa posterior, para cada proposição foi feita uma classificação inicial com relação ao caráter da proposição, como "conservadora" ou "progressista" 44 . Essa caracterização foi feita a partir das leituras das ementas e inteiro teor de cada documento. Iniciativas que traziam concepções patriarcais de família, defesas heternormativas da sexualidade, inclusão de aspectos religiosos nos currículos educacionais prescritos e perspectivas de doutrinação da prática docente, entre outras características similares, foram classificadas como conservadoras. Aquelas que traziam perspectivas educacionais emancipatórias, laicas e democráticas, foram classificadas como progressistas. Foram chamadas de

\footnotetext{
${ }^{44}$ As palavras "conservadora" e "progressista" estão entre aspas ("“") por entendê-las com categorias ainda em construção e que, portanto, possui limites. Enquanto a utilização do termo "conservador" se justifica pela abordagem teórica utilizada nessa tese, o termos "progressista" busca abarcar perspectivas educacionais emancipatórias, laicas e plurais.
} 
ambíguas aquelas que traziam um texto confuso, ou que misturavam proposições conservadoras e pressupostos plurais, tais como liberdade, segurança e laicidade, como será discutido futuramente. Dúvidas quanto ao caráter de alguns projetos foram levadas para discussão com o grupo maior e debatidas à luz das leituras realizadas pelo Diversias.

Neste trabalho, explorei os dados levantados a partir de dois movimentos: Num primeiro momento apresento as características gerais do levantamento: frequência de proposições por período, partido, natureza e situação. Posteriormente, dentro daquelas que apresentam natureza conservadora, busco os agentes, argumentos, valores e marcas neoconservadoras. Após a identificação destes elementos, busco dialogar com o referencial teórico e trazer inferências e reflexões sobre a educação nacional. A análise das iniciativas parlamentares não esgota, contudo, o escopo analítico desta pesquisa. A seguir, explicito os caminhos seguidos durante a análise de trechos e contextos de políticas públicas implementadas ou em fase de implementação, como é o caso do PNE, da BNCC, e da Reforma do Ensino Médio e do PECIM - Programa Nacional de Escolas Cívicos-Militares.

\subsection{Trechos e contextos: a análise dos 'imbróglios' relacionados ao PNE, à BNCC e à Reforma do Ensino Médio}

O PNE, a BNCC e a Reforma do Ensino Médio foram escolhidos para integrar o escopo desta pesquisa por figurarem como políticas públicas nacionais implementadas no contexto vigente e por trazerem - em maior ou menor grau marcas da agenda conservadora sobre o campo educacional. Entendimento que encontra suporte em recentes análises apresentadas por diferentes autores (ROSADO-NUNES，2015; PICCININI; ANDRADE，2018; SEPULVEDA; SEPULVEDA, 2019). Dessa forma, buscarei discutir trechos (e contextos) envolvidos no processo de construção e implementação destes documentos a partir de uma ordem cronológica: i. o PNE, precursor entre os três documentos e, portanto, o primeiro a servir de objeto na disputa pela orientação da narrativa educacional, i. a BNCC, também construída em meio a um processo conturbado de ruptura política e social, e, por fim, iii. a Reforma do Ensino Médio, construída num cenário de guinada neoliberal. 
A opção por discutir esses documentos a partir de trechos e contextos de construção se deu pelo entendimento de que para a justa realização dos objetivos desta investigação implicaria analisar recortes significativos das disputas e valores envolvidos (Figura 11). Ao contrário, os contextos analisados são tão ou mais valiosos do que o que efetivamente encontra-se escrito em documentos como o PNE e a BNCC, por exemplo. Os silenciamentos no texto em relação a certas temáticas, tal como será discutido a diante são oriundos de pressões conservadoras potentes (SEPULVEDA; SEPULVEDA, 2019).
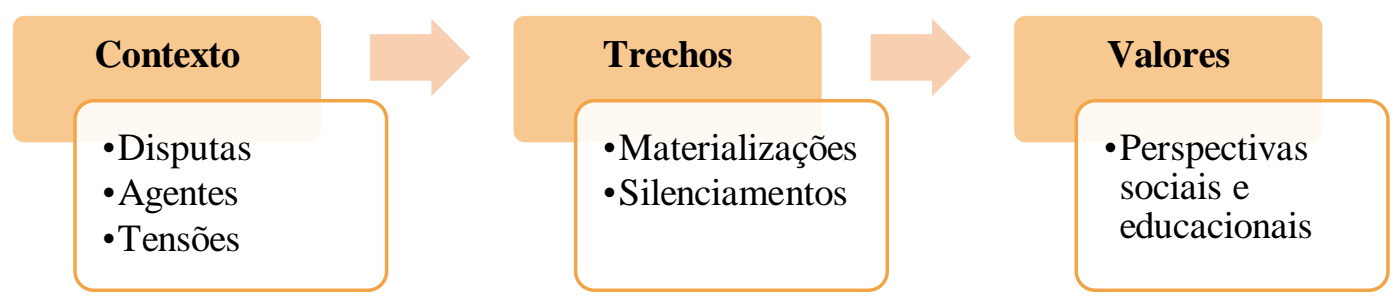

Figura 11: Dimensões analisadas nos documentos oficiais PNE, BNCC, lei 13.415/2017.

Assim, o olhar direcionado a esses contextos teve como objetivo encontrar essas dinâmicas de tensão e negociação, bem como os sujeitos que as capitanearam. Nos documentos busquei a materialização destes contextos de disputas na escrita de cada um. Ao final da análise conjunta de texto e contexto, busco discutir as perspectivas e valores que embasam essas políticas públicas educacionais no que se refere às temáticas de interesse da pesquisa. Por entender, no entanto, que essas políticas antecedem o Governo Bolsonaro, expressão máxima até então do novo conservadorismo político brasileiro (ALMEIDA, 2019), optei por trazer para análise materiais mais próximos de sua gestão. É a apresentação deles que passo a seguir.

\subsection{O manifesto, o discurso e o programa: a análise de outras fontes de influência (e poder)}

Esse grupo de materiais que integra a análise corresponde responde respectivamente ao Manifesto à Nação (FRENTE PARLAMENTAR EVANGÉLICA, 2018), aos discursos de posse do Presidente da República Jair Bolsonaro em $1^{\text {o }}$ de janeiro de 2019 e, por último, ao Programa Nacional das Escolas Cívico Militares - PECIM (DECRETO 10.004/2019). A opção por estas 
fontes materiais se justifica pela busca de respostas para o seguinte questionamento: como de fato se organiza a lógica neoconservadora no Governo Bolsonaro, dada sua autodeclaração "conservador nos costumes e liberal na economia". A dinâmica de análise destes materiais parte da leitura de inteiro teor dos documentos (e transcrição, como é o caso do discurso de Jair Bolsonaro em sua posse) e da identificação de nexos com as temáticas de interesse aqui discutidas (Figura 12).
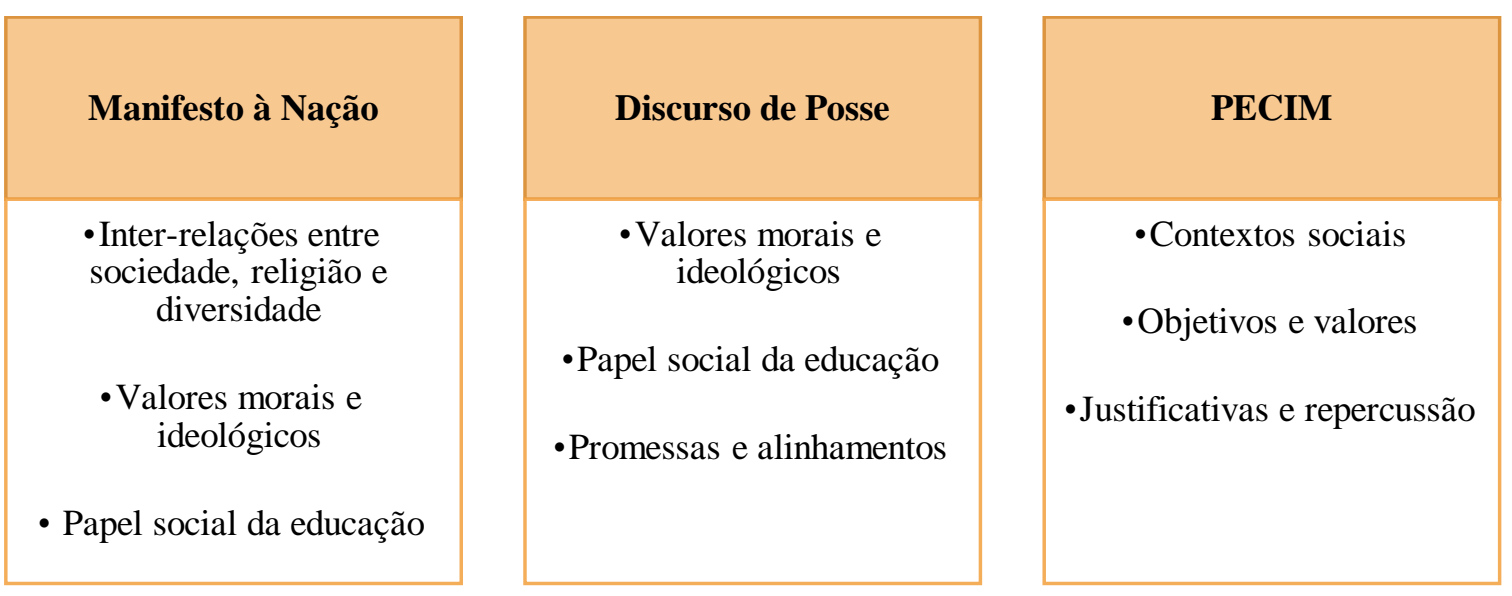

Figura 12: Dimensões a serem analisadas no Manifesto à Nação, nos Discursos de Posse de Jair Bolsonaro e no PECIM

Entendo que apesar de o Manifesto não ter sido produzido pela equipe de Jair Bolsonaro, sua divulgação se deu em meio à polarizada disputa eleitoral em que este se elegeu e foi entregue a ele por seus criadores como um ato de apoio e fé em sua capacidade de redirecionar a política nacional ${ }^{45}$. O PECIM $^{46}$, por sua vez, corresponde à instituição de escolas cívico-militares em todo território nacional. Um programa que tem como público-alvo escolas públicas em situação de vulnerabilidade social e que propõe a melhoria da qualidade da educação ofertada no Ensino Fundamental e Médio. Juntos esses materiais podem ofertar com maior clareza os caminhos pretendidos e já percorridos pela agenda neoconservadora ao longo dos primeiros dois anos do governo Bolsonaro. Somados aos documentos e levantamento de iniciativas parlamentares anteriormente apresentados, acredito ter material suficiente para discutir não só a atuação da agenda neoconservadora na educação e suas influências para a área de educação em Ciências e Biologia, como

45 Frente Parlamentar Evangélica e o Manifesto à Nação. Disponível em: https://politica.estadao.com.br/blogs/coluna-do-estadao/bancada-evangelica-propoe-em-manifestopauta-alem-de-costumes/. Acesso em 20/08/2020.

$46 \quad$ Programa Nacional das Escolas Cívico-Militares. Disponível em:
http://escolacivicomilitar.mec.gov.br/. Acesso em 07/10/2020. 
também refletir sobre possíveis estratégias de enfrentamento dessa realidade que se impõe à educação nacional.

\subsection{O tratamento analítico: perspectivas teóricas e aspectos práticos}

Explicitados os percursos de obtenção e natureza dos materiais que integram o corpus analítico, passo a apresentar o referencial metodológico empregado no tratamento e análise dos dados. A perspectiva teórico metodológica adotada nesta pesquisa é a Análise de Conteúdo de Bardin (2016). Tal escolha se deu pelo entendimento de que esta técnica, ao equilibrar o anseio pela descoberta e o apreço pelo rigor metodológico, permite a compreensão das comunicações investigadas para além de seu sentido imediato, favorecendo desta maneira o entendimento das mensagens produzidas em certo contexto em um nível mais profundo que uma leitura comum.

Sobre as etapas do método de Análise de Conteúdo aqui utilizadas, empregamos àquelas definidas por Bardin (2016) (Figura 13):

Figura 13:Ilustrativo das etapas do método de análise de conteúdo segundo Bardin (2016) utilizadas nesta pesquisa

- A fase de Pré-análise compreende a organização do material a ser analisado. Seu objetivo é torná-lo operacional a partir da sistematização das informações iniciais. Subdividida em quatro etapas: (i) leitura flutuante: neste primeiro contato com o material obtido realiza-se uma leitura compreensiva dos mesmos em busca da percepção de recorrências e regularidades; (ii) escolha dos documentos: nesta etapa realiza-se a escolha dos materiais a serem utilizados na investigação, demarcando o que de fato integrará o corpus da pesquisa; (iii) formulação das hipóteses e dos objetivos: São realizadas as primeiras formulações de hipóteses a serem avaliadas futuramente; (iv) referenciação dos 
índices e elaboração de indicadores: determinação dos recortes de texto a serem decodificados (BARDIN, 2016).

- A fase de Exploração do material, ou Codificação, por sua vez, consiste na realização de decodificação, separação dos núcleos de sentido que compõem o material, reagrupamento das recorrências em torno dos eixos analisados. Nesta etapa são identificadas as unidades de registro (unidade de significação que visa categorização e/ou à enumeração) e as unidades de contexto (unidade de compreensão contextual e agrupamento das unidades de registros utilizadas na investigação). $\mathrm{O}$ êxito nesta etapa está diretamente relacionado à possibilidade ou não da realização de futuras interpretações e inferências (BARDIN, 2016).

- Já a fase de Tratamento dos resultados e realização de inferências $e$ interpretações é última etapa e se destina à interpretação do material de análise obtido de acordo com o referencial teórico. Nesta etapa, o pesquisador/analista precisa ter domínio do referencial a fim de realizar uma análise criteriosa (BARDIN, 2016). Para Gomes (2007), uma boa interpretação quando ocorre uma síntese fluída entre as questões norteadoras da pesquisa, os resultados obtidos através da análise do material empírico obtido e o referencial teórico adotado.

A análise de conteúdo aqui realizada é a temática com temas (unidades de registros) definidos a priori, a partir das contribuições trazidas pelo referencial teórico e pela revisão bibliográfica (Quadro 7). Segundo Bardin (2016), o tema é uma unidade que salta aos olhos em um texto analisado de acordo com os critérios estabelecidos pela teoria de referência. Para a autora, o texto pode ser recortado em ideias constituintes, enunciados e proposições que comunicam significados a serem explorados. Em suas palavras,

Fazer uma análise temática, consiste em descobrir os núcleos de sentido que compõem a comunicação e cuja presença, ou frequência de aparição podem significar alguma coisa para o objetivo analítico escolhido (BARDIN, 2016, p.135).

Por trabalhar com o tema como unidade de registro, a unidade de contexto será entendida como o lugar no qual a primeira foi identificada, ou seja, se um 
registro for destacado no Manifesto à Nação (FRENTE PARLAMENTAR, 2018), esta será a unidade de contexto.

\begin{tabular}{|c|c|}
\hline Código & Definição \\
\hline $\begin{array}{c}\text { Educação em posição } \\
\text { central }\end{array}$ & $\begin{array}{l}\text { A discussão/reflexão/discurso gira em torno do processo educacional e seu } \\
\text { universo. Segundo os achados do levantamento bibliográfico realizado } \\
\text { (AUTORA, 2021). }\end{array}$ \\
\hline $\begin{array}{c}\text { Educação em posição } \\
\text { auxiliar }\end{array}$ & $\begin{array}{l}\text { A discussão/reflexão/discurso usa o processo educacional e seu universo como } \\
\text { componente relevante em argumentações mais amplas. Segundo os achados do } \\
\text { levantamento bibliográfico realizado (AUTORA, 2021). }\end{array}$ \\
\hline $\begin{array}{c}\text { Discussões sobre } \\
\text { Diversidade Sexual }\end{array}$ & $\begin{array}{l}\text { A discussão/reflexão/discurso traz conceituações, embates e definições sobre } \\
\text { diversidade sexual, homossexualidade, LGBT, orientação sexual e identidade de } \\
\text { gênero relacionadas à educação em suas argumentações. Segundo os achados do } \\
\text { levantamento bibliográfico realizado (AUTORA, 2021). }\end{array}$ \\
\hline $\begin{array}{c}\text { Discussões sobre } \\
\text { Laicidade }\end{array}$ & $\begin{array}{l}\text { A discussão/reflexão/discurso traz conceituações, embates e definições sobre } \\
\text { laicidade e Estado Laico relacionadas à educação em suas argumentações. } \\
\text { Segundo os achados do levantamento bibliográfico realizado (AUTORA, 2021). }\end{array}$ \\
\hline $\begin{array}{l}\text { Discussões sobre } \\
\text { Espaço Público / } \\
\text { Espaço Privado }\end{array}$ & $\begin{array}{l}\text { A discussão/reflexão/discurso traz conceituações, embates e definições sobre } \\
\text { espaço público e/ou espaço privado relacionadas à educação em suas } \\
\text { argumentações. Segundo os achados do levantamento bibliográfico realizado } \\
\text { (AUTORA, 2021). }\end{array}$ \\
\hline $\begin{array}{l}\text { Discussões sobre } \\
\text { Família e Valores } \\
\text { Familiares }\end{array}$ & $\begin{array}{l}\text { A discussão/reflexão/discurso traz conceituações, embates e definições sobre } \\
\text { família e valores familiares relacionadas à educação em suas argumentações. } \\
\text { Segundo as reflexões trazidas por Lacerda (2019). }\end{array}$ \\
\hline $\begin{array}{l}\text { Discussões sobre as } \\
\text { funções da Educação }\end{array}$ & $\begin{array}{l}\text { A discussão/reflexão/discurso traz conceituações, embates e definições sobre a } \\
\text { função da educação, da escola e do processo educacional como um todo em suas } \\
\text { argumentações. Segundo as reflexões trazidas por Apple }(2002,2003) \text {. }\end{array}$ \\
\hline $\begin{array}{c}\text { Moralização } \\
\text { Religiosa }\end{array}$ & $\begin{array}{l}\text { A discussão/reflexão/discurso traz conceituações, embates e definições sobre o } \\
\text { processo educacional calcadas na moral e nos valores religiosos em suas } \\
\text { argumentações. Segundo as reflexões trazidas por Apple (2002, 2003), Almeida } \\
\text { (2017) e Lacerda (2019). }\end{array}$ \\
\hline $\begin{array}{c}\text { Racionalidade } \\
\text { Econômica }\end{array}$ & $\begin{array}{l}\text { A discussão/reflexão/discurso traz conceituações, embates e definições sobre o } \\
\text { processo educacional calcadas nos preceitos neoliberais e economicistas em suas } \\
\text { argumentações. Apple }(2002,2003) \text {, Almeida (2017) e Lacerda (2019). }\end{array}$ \\
\hline $\begin{array}{c}\text { Ordem e } \\
\text { Militarização }\end{array}$ & $\begin{array}{l}\text { A discussão/reflexão/discurso traz conceituações, embates e definições sobre o } \\
\text { processo educacional calcadas nos preceitos de ordem, disciplina militar e culto } \\
\text { ao passado em suas argumentações. Apple }(2002,2003) \text {, Almeida (2017) e } \\
\text { Lacerda (2019). }\end{array}$ \\
\hline $\begin{array}{l}\text { Antagonismos } \\
\text { Sociais }\end{array}$ & $\begin{array}{l}\text { A discussão/reflexão/discurso traz conceituações, embates e definições sobre o } \\
\text { processo educacional calcadas em preconceitos, antagonismos, e demonização de } \\
\text { ordem política, cultural, religioso e social em suas argumentações. Apple (2002, } \\
\text { 2003), Almeida (2017) e Lacerda (2019). }\end{array}$ \\
\hline
\end{tabular}


Quadro 7: Lista de códigos definidos à priori como unidades temáticas de registro da análise de conteúdo realizada. FONTE: AUTORA, 2021.

Após a etapa de codificação, passei então à categorização semântica dos dados, que, segundo Bardin (2016), parte da separação dos elementos analisados (estabelecimento códigos) à reorganização em eixos maiores (categorias). Ainda segundo Bardin (2016), boas categorias devem seguir algumas regras: exclusivas (capacidade de comunicação não ambígua), homogêneas (não díspares entre si), pertinentes às questões de pesquisa, objetivas e fidedignas aos dados e achados e produtivas (capazes de produzir reflexões gerais e inferências). Por entender que a exploração das categorias está intimamente ligada aos resultados encontrados e suas discussões apresentarei cada uma no próximo capítulo deste trabalho de tese.

Por fim, destaco o emprego do software Atlas. TI versão 9.023 na análise dos dados. O software em questão corresponde a uma potente ferramenta de auxílio no tratamento de dados qualitativos. Ao permitir codificar textos diretamente no material importado para sua interface, facilita a leitura flutuante, a referenciação, formação de grupos de códigos que fazem as vezes de categoriais iniciais e, posteriormente, na formação de redes de grupos de código (categorias). A análise de conteúdo de Bardin exige que se apresente as unidades de registro e contexto utilizadas em uma análise, ao permitir o destaque de citações associadas aos códigos, o Atlas TI ajuda a tornar mais visual essa etapa.

A versão 9.023 do software contém recursos interessantes a uma análise qualitativa, tais como a possiblidade de analisar materiais em áudio e vídeo, bem como a formação de nuvens de palavras, entre outros (SILVA JÚNIOR; LEÃO, 2018). Nesta investigação, utilizei o software principalmente nas etapas de referenciação (construção de índices e indicadores) e categorização. Após essas etapas, os resultados foram exportados para posterior discussão no Microsoft Word (programa de criação e edição de textos). Apresentadas as etapas de obtenção e tratamento dos dados, passo à apresentação e discussão dos resultados obtidos na seção seguinte. 


\title{
6. Análise e discussão dos resultados
}

O neoconservadorismo se distingue dos movimentos de direita tradicionalmente conhecidos por articular aspirações neoliberais e ativismo moral de regulação dos desejos, corpos e comportamentos (LACERDA, 2019). A ascensão da Nova Direita estadunidense ao poder entre as décadas de 1970 e 1980 evidencia tal dinâmica ao conjugar um forte combate ao Estado de Bem-Estar Social, demandas securitárias punitivistas e influência moral cristã/evangélica (O’SULLIVAN, 2013). Os impactos culturais e políticos desse projeto político se faz sentir ainda hoje não apenas em seu país de origem, como também influencia as dinâmicas de outros contextos políticos, como é o caso do Brasil. Para Marina Lacerda (2019), a atuação parlamentar da direita cristã brasileira, sobretudo após os eventos políticos de 2013 e suas reverberações, apontam essa percepção com clareza. Em suas palavras,

\begin{abstract}
... os aspectos que aproximam o neoconservadorismo norteamericano e o novo conservadorismo brasileiro residem no cerne do argumento neoconservador: a união de princípios de autoridade militar e religiosa, associados à livre competição e ao enriquecimento individual; os valores morais rígidos em um mundo de inseguranças; a família como projeto de boa sociedade. Se as respostas baseadas em políticas públicas de bem-estar social parecem longínquas, as respostas neoconservadoras parecem bastante imediatas (p.204).
\end{abstract}

A imediata demanda por mudanças é apontada por Joanildo Burity (2018) como uma das pautas "antissistema" que ganharam as ruas, cimentaram a derrocada do governo petista de centro-esquerda e convergiram para o crescimento da onda conservadora que tomou o país. Para Ronaldo Almeida (2017), a onda conservadora é na verdade uma "onda quebrada" que conjuga diferentes agentes e agendas e se compõem de linhas de força ora complementares, ora divergentes: moral, econômica, securitária e interacional. Nesse sentido, Jair Bolsonaro figura, então, como uma síntese desse processo que ainda se encontra em desenvolvimento (ALMEIDA, 2019; LACERDA, 2019).

A questão educacional surge nesse contexto como um campo de disputas relevante. Dada sua capacidade de socialização e formação em valores, além da apresentação e construção ativa de saberes, a educação enquanto instituição passa 
a ser entendida simultaneamente como um lócus perigoso, quando comprometida com a formação crítica e plural de seus educandos, e atraente, pelo potencial de difusão dos interesses e agenda neoconservadores. Para Michael Apple (2002), ao redefinir as funções educacionais e pautá-las em valores como competividade mercadológica, autoritarismo moral religioso e transmissão "neutra" de conhecimentos, a atuação neoconservadora sobre a educação busca esvaziá-la de seu componente político e emancipatório estruturante.

É nesse sentido que o Luís Antônio Cunha (2016), professor e sociólogo, afirma que

o currículo da Educação Básica brasileira, particularmente das escolas públicas, é objeto de ação modeladora que visa frear os processos de secularização da cultura e de laicidade do Estado, mediante dois movimentos, um de contenção, outro de imposição (p. 2)

A partir desse entendimento, fiz desta investigação uma busca por indícios da atuação neoconservadora sobre a educação nacional. Os dados que exploro nessa seção buscam identificar os principais elementos que compõem os programas e ações neoconservadoras em curso atualmente no cenário educacional brasileiro. Busco, então, discutir as lógicas, valores, ideais e referencial que embasam as argumentações conservadoras. A partir dessas discussões procuro refletir sobre os possíveis impactos dessas agendas sobre a Educação como um todo. Por entender a Educação em Ciências e Biologia como uma área curricular de forte interesse às forças neoconservadoras, dada sua entrada a assuntos caros a estes grupos como sexualidade, criação do universo e evolução biológica, saúde e raças (BORBA et al., 2019), proponho um exercício de reflexão e inferência sobre as implicações da atuação conservadora sobre ela.

Para realizar tais objetivos busquei analisar diferentes materiais: iniciativas parlamentares, trechos e contextos de políticas públicas, o manifesto da Frente Parlamentar Evangélica, o discurso de posse de Jair Bolsonaro, presidente autodeclarado conservador, e o decreto presidencial instituindo o Programa de Escola Cívico-Militares. A opção por investigar materiais diferentes em suas origens se justifica pela influência que exercem sobre o projeto educacional vigente em todo o país.

Nesta seção apresento e discuto os resultados obtidos. Acredito que os dados aqui apresentados permitem refletir não somente sobre o atual momento, como 
também inspiram reflexões sobre estratégias potentes de ação futuras e empoderamento frente aos embates atuais, pois situam a discussão sobre uma educação mais democrática e plural num contexto social atravessado por projetos políticos (e pedagógicos) autoritários.

\subsection{Atuação parlamentar em números: tendências, inclinações e agentes}

Abro a discussão dos dados a partir do levantamento referente à atuação parlamentar na Câmara dos Deputados entre os anos 2001-2020 por entender que os resultados emergentes servem de balizadores das discussões futuras. De forma sintética é possível afirmar que, durante o período analisado, 187 proposições que conjugam as temáticas de interesse da pesquisa foram encontradas. Destas, 106 foram consideradas conservadoras, 65 progressistas e 17 ambíguas (Figura 14).

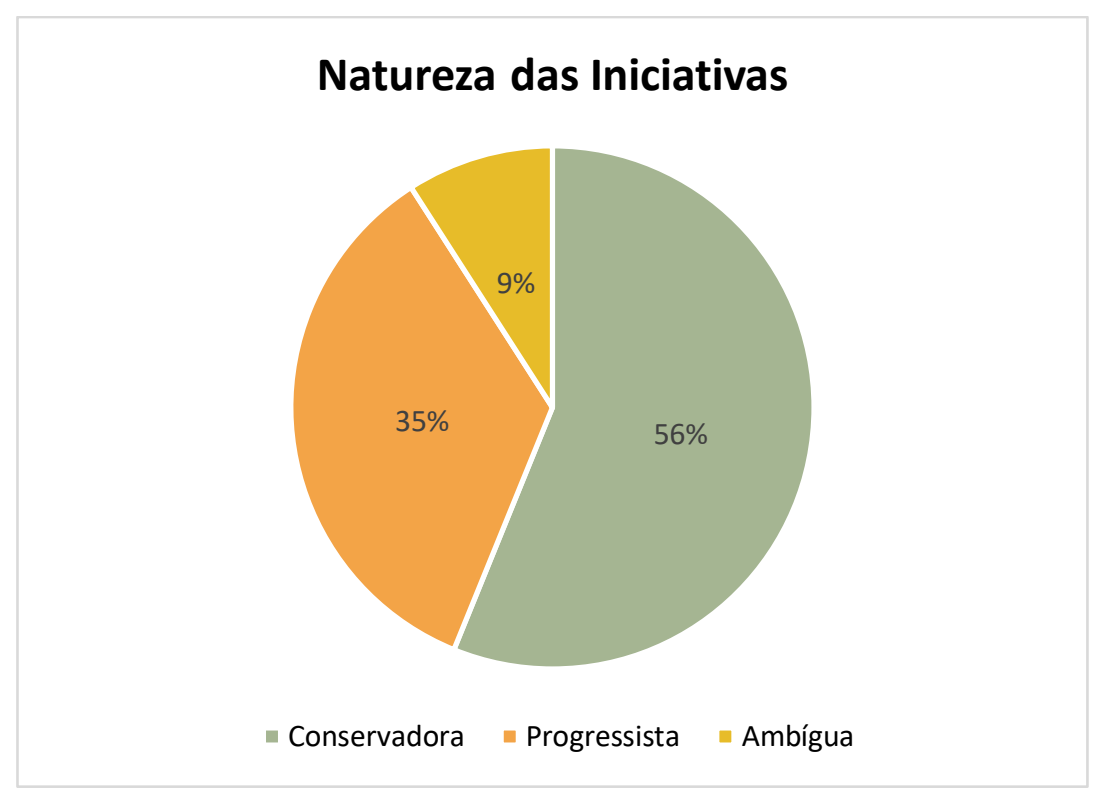

Figura 14: Classificação das iniciativas parlamentares segundo a natureza das proposições. Fonte: a autora a partir de dados do site da Câmara dos Deputados. FONTE: AUTORA (2021)

Conforme apresentado na seção metodológica, a caracterização da natureza das proposições parlamentares foi realizada a partir das leituras das ementas e inteiro teor de cada documento. Iniciativas que traziam concepções patriarcais de família, defesas heteronormativas da sexualidade e gênero, inclusão de aspectos religiosos e militares nos currículos educacionais, bem como apontamentos acerca da doutrinação docente, entre outras características similares, foram classificadas 
como "conservadoras". Já aquelas que traziam perspectivas educacionais emancipatórias, laicas e democráticas, foram classificadas como "progressistas". Foram chamadas de ambíguas aquelas que traziam um texto que articulava aspectos conservadores, com pressupostos plurais e tolerantes, como liberdade e laicidade, por exemplo. Também foram consideradas ambíguas aquelas que traziam um texto pequeno, objetivo e sem marcas tão evidentes de demandas conservadoras ou progressistas em suas justificativas. Adianto que esse grupo de textos se mostrou um desafio para análise e categorização, pois ao fazer uso de um linguagem "neutra" ou "mista" poderiam induzir ao erro. Além disso, alguns foram propostos por parlamentares ligados aos interesses e demandas conservadoras em outros assuntos. Voltarei a esse assunto futuramente. Essa primeira categorização teve como apoio epistêmico tanto a discussão sobre o novo conservadorismo brasileiro trazido por Lacerda (2019), quanto os aspectos trazidos por Almeida (2019) ao discutir as linhas de força neoconservadora. Seu objetivo é apontar o quadro geral de assuntos tratados pelos parlamentares e as dinâmicas de frequência e distribuição ao longo do tempo.

Um questionamento que antecedeu o levantamento propriamente dito foi: “teria o conservadorismo crescido após o ano de 2013, conhecido pela explosão das pautas conservadoras que ganharam as ruas no bojo do sentimento generalizado de descontentamento populacional que organicamente ganharam as ruas e depois foram cooptadas por movimentos de direita e extrema-direita?". Assim, dois períodos de análise foram estabelecidos: 2001 - 2012 e 2013 - 2020. Cabe informar que o primeiro deles cobre os dois últimos anos do Governo Fernando Henrique Cardoso - FHC (1995-2002), todo o Governo Lula (2003-2010) e a metade do primeiro Governo Dilma (2011-2012). Enquanto o segundo corresponde aos anos finais do governo petista (2013-2016), passa pela gestão Temer (2016-2018) e compreende os dois primeiros anos do Governo Bolsonaro (2019-2020).

Destaco que a escolha desses períodos não se deu arbitrariamente, ao contrário, busquei englobar em dois ciclos distintos de influência e atuação conservadora sobre os rumos políticos nacionais. Entendido como um período anterior à mais recente ascensão conservadora ao poder, o primeiro marco temporal analisado, 2001-2012, inclui os dois últimos anos do Governo FHC como tentativa de identificar possíveis mudanças das dinâmica e tendência na atuação parlamentar em relação aos governos petistas mais posicionados à esquerda que seu antecessor. 
Já o segundo período analisado, 2013-2020, carrega as marcas de um processo de insatisfação política gestado nas instâncias políticas, civis e militares que determinaram o contexto atual.

De acordo com análise realizada é possível observar que o conservadorismo educacional cresceu bastante após o período mencionado. As listas de iniciativas parlamentares consideradas "conservadoras", "progressistas" e "ambíguas" ao longo do total de anos investigados (2001-2020). Destaco mais uma vez a consciência de que estas categorias têm potenciais e limites. Se por um lado ajudam a organizar as principais tendências encontradas dentro do campo analisado a partir de disposições e similaridades retóricas e ideológicas, por outro não podem ser consideradas categorias analíticas absolutas dada a amplitude do espectro de filiações em questão. Assim, entre os anos de 2002 e 2012, 63 iniciativas foram encontradas, sendo 33 delas identificadas como "conservadoras", 23 “progressistas" e 7 "ambíguas" (Figura 15). Já entre os anos 2013 e 2020, foram encontradas 127 proposições, dessas 72 foram identificadas como "conservadoras", 42 como "progressistas" e 10 como "ambíguas" (Figura 16). De imediato é possível perceber que o número de iniciativas gerais dobra o volume encontrado para o período anterior.

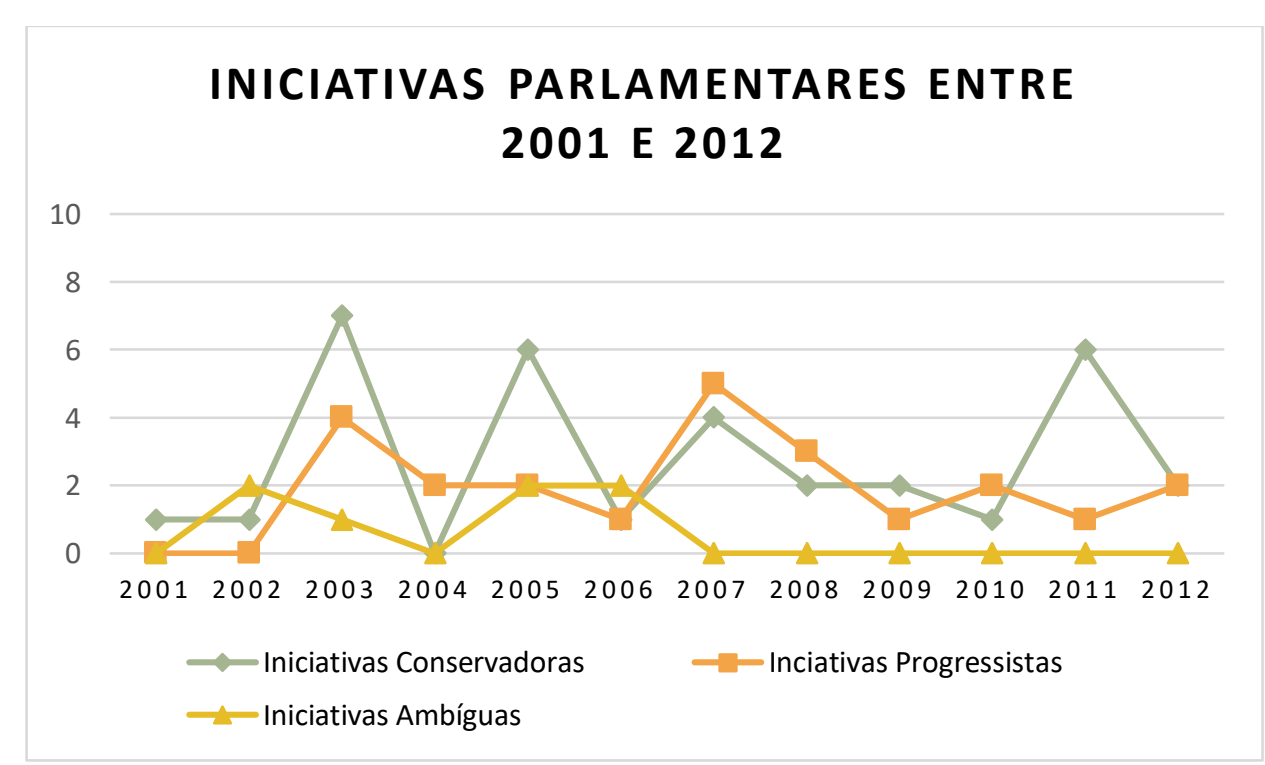

Figura 15: Número de proposições separadas por natureza entre os anos 2002-2012. FONTE: AUTORA (2021)

O gráfico acima mostra que, de maneira geral, há certa alternância reativa entre os picos de proposições entre as categorias apresentadas, especialmente entre 
as de teor considerado conservador e progressista. De maneira geral, é possível observar já em 2003 a ocorrência do primeiro pico de iniciativas parlamentares conservadoras relacionadas à educação, seguido de um número maior de propostas consideradas progressistas (2004), com um novo pico de natureza conservadora (2005). Com exceção dos anos 2002 e 2006 em que os textos de natureza ambígua são maioria, a tendência reativa se mantem entre 2007 e 2011. Em 2012 há empate entre propostas conservadoras e progressistas. É interessante observar que os picos conservadores ocorridos nos anos 2003, 2005 e 2011 não coincidententemente ocorrem em paralelo a eventos políticos relevantes para a história do país: o primeiro ano do Governo Lula, ex-sindicalista e metalúrgico considerado um líder carismático no campo político à esquerda, a primeira grande crise política do governo petista acusado de crimes de corrupção (o chamado "Mensalão") e, por fim, o primeiro ano do Governo Dilma Rousseff, primeira mulher eleita Presidente do Brasil, respectivamente.

Tal dinâmica reativa, caracterizada por aumentos de pautas conservadoras em um posterior a um período de maior demanda progressista, corrobora as reflexões trazidas por Marina Lacerda (2019). Para a autora, a ação reativa aos avanços nos direitos e garantias sociais por parte de grupos vulneráveis e minoritários alcançados pela agência civil e política de movimentos sociais caracteriza o neoconservadorismo. A partir dessa percepção é possível inferir que a atuação progressista em maior expressividade agite as bases conservadoras e as impele à ação no sentido contrário, ou seja de contenção de possíveis avanços de pautas às quais se opõem.

Os considerados ambíguos dentro deste período apresentaram maior frequência na primeira metade dos anos investigados (2001-2006), superando, ou mesmo igualando, em alguns momentos, as demais. Na segunda metade (2007 2012) não foram encontradas inciativas desta natureza. Retornarei a essa categoria futuramente. 


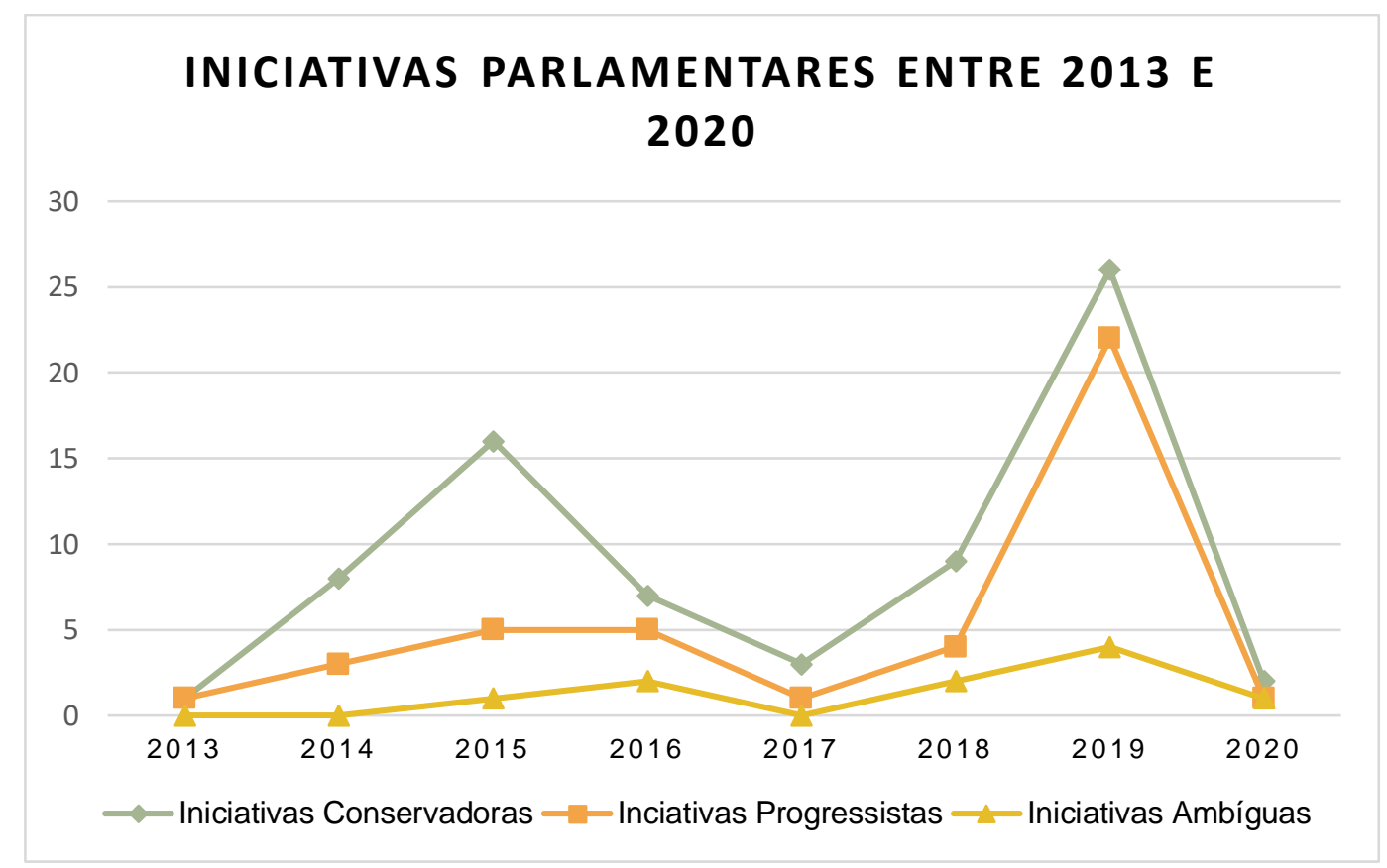

Figura 16: Número de proposições separadas por natureza entre os anos 2013-2020. FONTE: AUTORA (2021)

As informações obtidas para o segundo período analisado (2013-2020) evidenciam o aumento expressivo de iniciativas consideradas conservadoras em relação às demais. O gráfico acima mostra que em nenhum momento nesse período as proposições progressistas relacionadas à educação superaram aquelas de natureza conservadora. Após o ano de 2013 com baixíssimo número de proposições, as iniciativas conservadoras começam a subir em 2014 e apresentam o primeiro grande pico em 2015, época em que a insatisfação com o Governo Dilma cresce fortemente na mídia, nas redes sociais e no cotidiano do país. Com a abertura do processo de impeachment da presidenta petista aprovado no final do mesmo ano e aprovado em meados de 2016, as proposições relacionadas à educação diminuem para os níveis encontrados no período anteriormente discutido.

Em 2017, período de baixo número de propostas parlamentares de qualquer categoria relacionada à educação, os Poderes Legislativo e Executivo direcionaram suas atenções às polêmicas reformas econômicas discutidas na época: Reforma Trabalhista e Reforma da Previdência ${ }^{47}$. Um dado importante sobre o período reside

\footnotetext{
${ }^{47}$ No ano de 2017, os Poderes Legislativo e Executivo discutiram reformas econômicas de cunho neoliberal, como a Reforma da Previdência e a Trabalhista. Disponível em: https://www.diariodepernambuco.com.br/noticia/politica/2017/12/retrospectiva-relembre-osprincipais-fatos-politicos-de-2017.html Acesso em: 13/11/2020.
} 
no fato de que o Presidente em exercício, Michel Temer, em uma guinada neoliberal busca colocar em pauta propostas contrárias àquelas que elegeram a chapa Dilma Rousseff - Michel Temer em 2014. A tendência de subida retorna em 2018, e alcança números recordes em 2019, 26 iniciativas conservadoras e 22 inciativas consideradas progressistas, primeiro ano da gestão Bolsonaro. Já em 2020, ano em que a COVID-19 chega ao Brasil e as diretrizes sanitárias recomendam o distanciamento social, e, portanto, o ensino remoto, a tendência de proposições relacionadas aos temas investigados volta a diminuir.

Esses dados apontam um aumento das pautas conservadoras relacionadas à educação após 2013. A saber, em 2013 ocorreram as Jornadas de Junho, movimento de insatisfação popular que foi às ruas protestar contra o aumento de tarifas no transporte público, num primeiro momento. Para Joanildo Burity (2018), esse momento pode ser considerado o início da fragmentação do campo democrático. Ainda segundo o autor, a desorientação da esquerda somada a afinidade de setores descontentes com a gestão petista facilitara a emergência de demandas conservadoras que passaram a disputar, com êxito, a voz e a identidade popular. A influência desse período é expressa nos dados apresentados.

Os textos considerados ambíguos foram aqueles encontrados em menor número em relação às demais categorias. Diferente do período anterior, apesar dos baixos índices, essa categoria é observada ao longo dos anos investigados, com exceção de em 2013 e 2017. As especificidades destes e dos demais textos serão discutidas a seguir quando passo a apresentar temas que integram cada categoria, suas particularidades e demais aspectos.

\subsubsection{Iniciativas conservadoras e seus interesses}

Definidas a priori, os textos das inciativas parlamentares foram categorizados de acordo a natureza das proposições: "conservadoras", “progressistas" e "ambíguas". Dentro dessas categorias foram alocadas propostas legislativas que versavam sexualidade, religião, doutrinação, patriotismo/militarização de escolas e homeschooling. Tais temas foram elencados também a priori tendo por base as discussões realizadas por Michael Apple (2002), Ronaldo Almeida (2017) e Marina Lacerda (2019). A fim de entender em que medida cada um desses temas integra a atuação conservadora parlamentar no Brasil 
(Apêndice C), busquei contabilizar o número de proposições relacionados a cada um (Figura 17).

\section{Temas das Iniciativas Conservadoras}

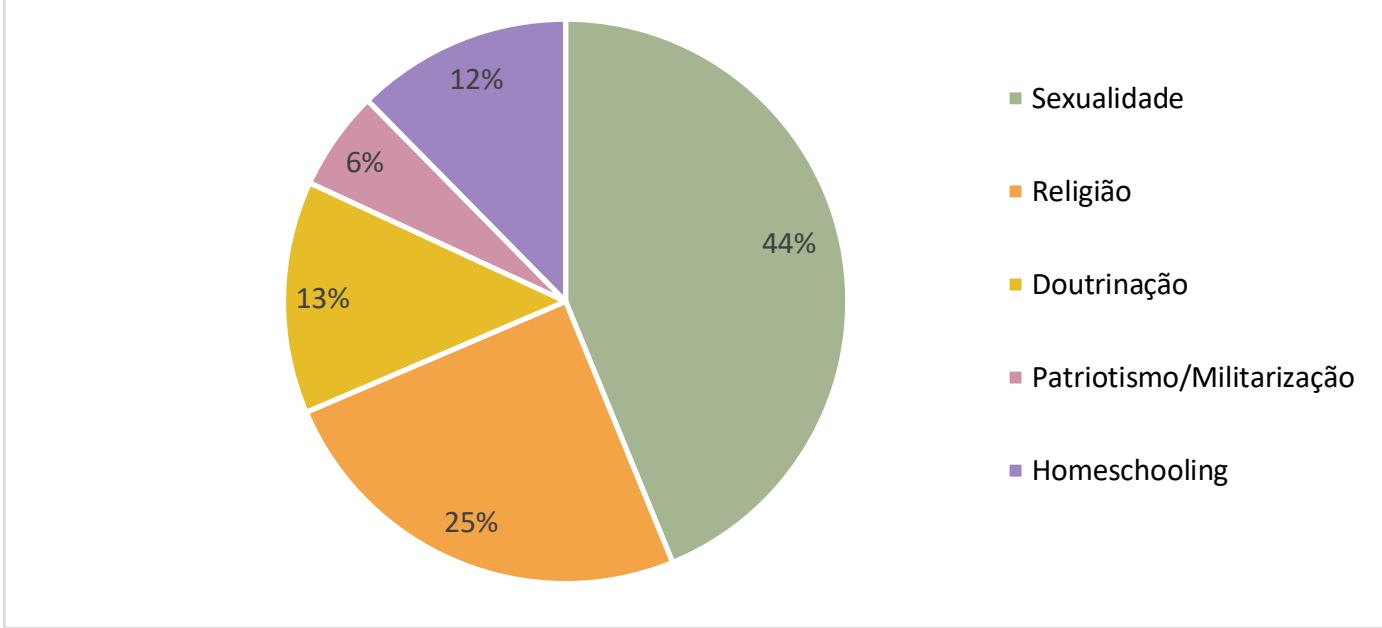

Figura 17: Temas das iniciativas parlamentares conservadoras identificadas entre 2001 - 2020. FONTE: AUTORA (2021)

A maior parte das 105 proposições conservadoras pauta as questões ligadas à sexualidade, somando 46 iniciativas. O segundo bloco de maior interesse é aquele que traz textos relacionados à religião, 26 proposições. Doutrinação e homeschooling aparecem no gráfico anterior respectivamente como o terceiro e o quarto maior interesse das proposições conservadoras voltadas para a educação na Câmara dos Deputados brasileira com 14 e 13 iniciativas encontradas, respectivamente. Por fim, com 6 textos, o último bloco de interesse apresentado pelas proposições conservadoras é aquele que versa sobre o patriotismo/militarismo.

A fim de aprofundar ainda mais esses achados, busquei também identificar o quanto as iniciativas estavam relacionadas à educação, ou seja, se abordavam a educação como objeto central ou a utilizavam como componente relevante em outras argumentações socioculturais (Figura 18). Combinadas, essas informações apontam que o ativismo neoconservador na Câmara dos Deputados busca atuar diretamente sobre os rumos da educação nacional, não se furtando, entretanto, de utilizar a educação como parte de sua retórica em discussões mais amplas relacionadas à sexualidade, religião, e, em menor grau patriotismo. 


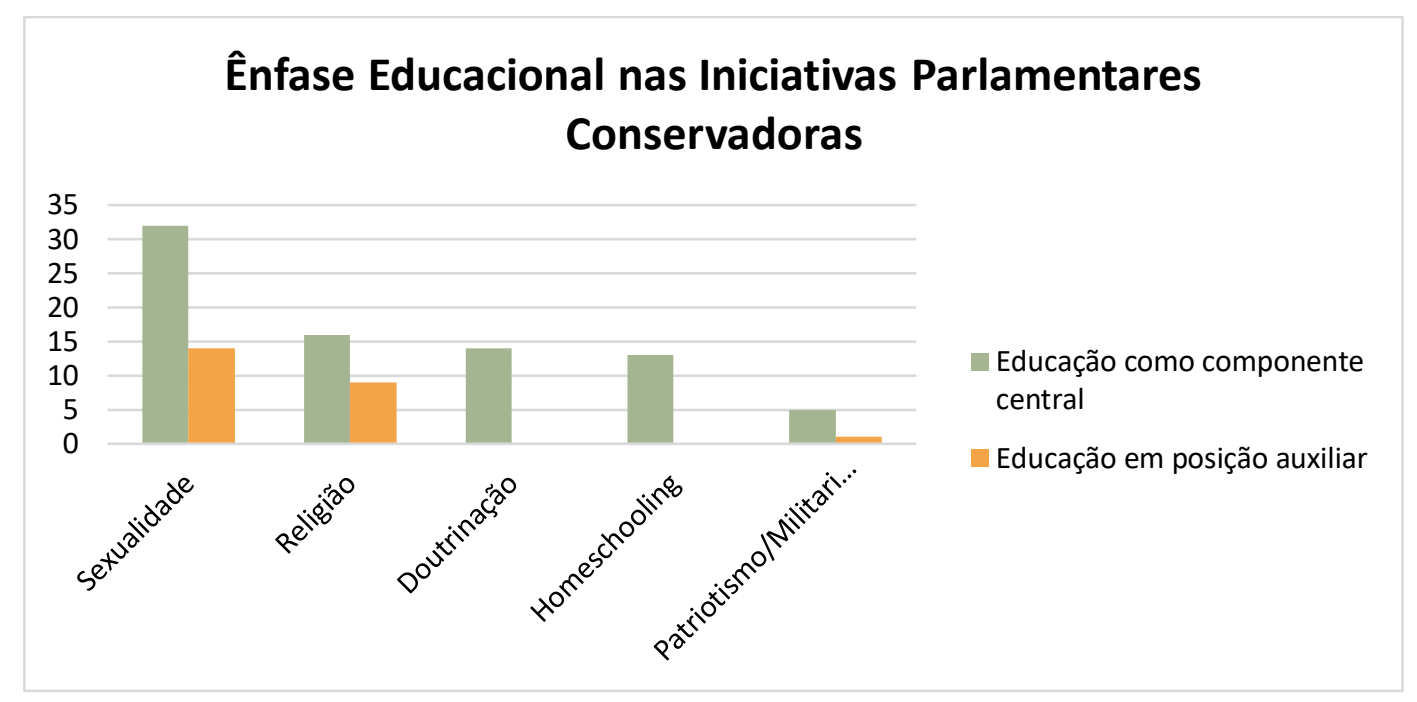

Figura 18: Lugar ocupado pela educação segundo as temáticas encontradas. FONTE: AUTORA:2021

Dentro do bloco temático Sexualidade, foi possível identificar quatro tipos de abordagens entre as proposições: combate à ideologia de gênero em ambiente escolar (22), discussões sobre gênero e sexualidade na sociedade em geral (11), orientação/proteção sexual (8), educação sexual propriamente dita (5). Dentre essas, os textos sobre ideologia de gênero e educação versam especificamente sobre o universo educacional, já aqueles que legislam sobre questões de gêneros em contextos sociais mais amplos utilizam a educação como parte de suas argumentações e justificativas. Por fim, os documentos que pretendem estabelecer condutas de orientação e proteção sexual a grupos vulneráveis como "crianças, adolescentes e mulheres" direcionam-se tanto ao ambiente escolar (5), quanto sobre a sociedade em geral (3). Embora atuem em frentes distintas, os textos desse bloco temático pautam-se pela compreensão de que existe um "padrão normal" da sexualidade humana e que ele conjuga valores éticos, morais e religiosos em sua composição. A lógica "pró-família tradicional” também surge em boa parte desses textos.

Exemplos dessas materializações podem ser observadas nos PLs 5918/2005 (Elimar Damasceno, PSC/RJ), 7551/2014 (Salvador Zimbaldi, PROS/SP). Separados por quase uma década os textos apontam a defesa dos valores familiares como aspectos fundamentais da sociedade. É possível observar essa postura prófamília na articulação de valores morais e religiosos nos argumentos s utilizados 
para defender que os estudantes não sejam obrigados a assistir às aulas de educação sexual:

\begin{abstract}
Vivemos tempos em que uma moral sexual permissiva é erigida em valor pelos meios de comunicação, vendida como modelo de vida moderna e de mentalidade cosmopolita pelas novelas e pela fantasia que se faz em torno da vida pessoal dos astros e estrelas da televisão e mais recentemente do futebol. Há que se lamentar, porém o tratamento que tal problemática vem recebendo das escolas. Dir-se-ia que, de maneira geral, a mesma "entrou na onda" de permissividade reinante, a qual encontra eco, inclusive, em intelectuais e especialistas de Psicologia e Ciências Sociais, entre outros. Por estas razões, proponho que sejam defendidos os direitos de pais e filhos que não concordam com esta forma de tratar a sexualidade, garantindo-lhes que não sejam constrangidos a participar de tais aulas. (...) a liberdade de crença e de consciência é direito inviolável de todos os brasileiros, como reconhece a CF. (PL5918/2005 - ELIMAR DAMASCENO, PSC/RJ. Grifos meus).
\end{abstract}

Já no texto de Zimbaldi, por sua vez, o objetivo central girava em torno da substituição do termo gênero por sexo biológico na Lei Maria da Penha - Lei $n^{\circ}$ 11.340/2006. Muito embora o projeto verse sobre aspectos da lei que coíbe a violência doméstica e familiar contra a mulher, a educação surge como um forte argumento dentro do texto, sendo apontada como um fator doutrinário e subversivo.

$\mathrm{Na}$ realidade, o conceito [de gênero] está sendo utilizado para promover uma revolução cultural sexual de orientação neomarxista. Na submissão do feminino ao masculino através da família, Marx e Engels enxergaram o protótipo de todos os subsequentes sistemas de poder. Se esta submissão é consequência da biologia, não há nada a que se fazer. Mas se ela é uma construção social, ou um gênero, então, a longo prazo, ela poderia ser modificada até chegar-se à uma completa igualdade onde não haveria mais possibilidade de opressão de gênero, mas também em que não haveria mais famílias, tanto heterossexuais como alternativas, em que a educação caberia como uma tarefa exclusiva do Estado, e onde não existiria nenhum traço diferencial entre o masculino e o feminino. Em um mundo de genuína igualdade, segundo esta concepção, todos teriam que ser educados como bissexuais e a masculinidade e a feminilidade deixariam de ser naturais (PL 7551/2014, SALVADOR ZAMBALDI, PROS/SP. Grifos meus). 
Retornarei às concepções sobre educação, família, diversidade, democracia e laicidade expressas nestes - e em outros - documentos posteriormente, quando discutirei as particularidades da atuação moralista na educação. No entanto, trago esses destaques para evidenciar a maneira como os documentos que integram esse bloco são marcados fortemente pela moral familiar e religiosa. A despeito de as proposições conservadoras não terem sido aprovadas até o momento (a maioria foi arquivada ou está tramitando apensados a outros textos por longos períodos), a frequência deste tipo de proposição mostra a força que esta temática assume no ideário conservador educacional. Segundo Ronaldo Almeida (2017), a linha de força moralmente reguladora disputa a moralidade pública a partir de pressupostos religiosos e ativismo pela inscrição destes na ordem legal do país.

O segundo bloco de interesse mais expressivo é aquele voltado para a temática religiosa. De modo geral, foram identificados três tipos de encaminhamentos: i. disposições sobre a obrigatoriedade e abordagem do ensino religioso em ambiente escolar (12) e ativismo pela inclusão de conteúdos religiosos em outras disciplinas curriculares (3), ii. determinações sobre ações de suporte religioso em diferentes segmentos sociais, incluindo-se instituições de educação básica e superior (6) e, por fim, iii. utilização do princípio de liberdade religiosa e laicidade em discussões/disputas sociais mais amplas (5). O primeiro encaminhamento descrito versa diretamente sobre o universo educacional, enquanto os demais o utilizam como elemento importante em sua retórica.

Tais dinâmicas podem ser observadas, respectivamente, nos PLs 2664/2003 (Adelor Vieira, PMDB/SC), 8099/2014 (Pastor Marco Feliciano, PSC/SP) e 3044/2015 (Takayama - PSC/PR). Os PLs supracitados se apoiam na defesa constitucional da liberdade de crença e consciência para justificar os mais diversos interesses cristãos. Adelor Vieira, em 2003, utilizou essa justificativa para advogar a não realização de concursos públicos e vestibulares em dias sagrados para algumas religiões cristãs. Em suas palavras,

O Brasil, País eminentemente cristão tem em sua Carta Magna a expressão máxima do apoio Constituinte. Desde os primórdios o apoiamento às crenças religiosas goza de amparo constitucional, sendo de se destacar o atual texto, em que manifesta explicitamente sua preocupação com a fé do seu povo. [...] Assim, por não existir nos demais Estados, instrumento legal para este mister, são frequentes e, por não dizer, quase 
constantes, a realização de concursos públicos e, devido ao grande número de instituições de ensino superior, a realização de vestibulares, muitos dos jovens que professam e tem como verdadeiros os princípios exarados nas Sagradas Escrituras, concernentes a Lei de Deus, suas religiões levando em linha de consideração a guarda do Sábado bíblico como aquele reservado ao dia especial de adoração e descanso semanal, são frequentemente preteridos e dificultada a sua participação em tais eventos, numa verdadeira contrariedade aos preceitos constitucionais (PL 2664/2003 - Adelor Vieira, PMDB/SC. Grifos meus).

A filiação cristã do deputado fica bastante evidente no final do texto

Diante de tais fatos, rogo aos ilustres pares o apoiamento necessário a ter a proposição ora apresentada devidamente aprovada, fazendo justiça com aqueles que elevam o nome do Todo Poderoso, professando sua fé religiosa e, com isso, engrandecendo o padrão moral e cultural do nosso País. Afinal de contas é a própria Bíblia Sagrada quem diz: "Bendita é a Nação cujo Deus é o Senhor” (PL 2664/2003 - Adelor Vieira, PMDB/SC. Grifos meus).

No Projeto de Lei 8099/2014, Marco Feliciano advoga a necessidade de oferecer uma contraposição curricular à Teoria Sintética da Evolução, paradigma fundamental das Ciências Biológicas. Segundo ele,

....a nossa Constituição Federal, mais precisamente em seu artigo $5^{\circ}$ onde trata dos direitos e deveres individuais e coletivos, nos incisos VI e VIII do citado dispositivo legal "É inviolável a liberdade de consciência e de crença, (...) ninguém será privado de direitos por motivo ou de convicção filosófica ou política." Assim sendo ensinar apenas a teoria do evolucionismo nas escolas, é violar a liberdade de crença, uma vez que a maioria das religiões brasileiras acredita no criacionismo, defendido e ensinado na Igreja Católica, que ainda hoje é maioria no país, pelos evangélicos e demais denominações assemelhadas (PL 8099/2014 - Pr. Marco Feliciano, PSC/SP. Grifos meus).

Ainda segundo o deputado e pastor evangélico

as crianças que frequentam as escolas pública tem se mostrado confusas, pois aprendem nas suas respectivas escolas noções básicas de evolucionismo, quando chegam a suas respectivas Igrejas aprendem sobre o criacionismo em rota de colisão com conceitos de formação escolar e acadêmica (PL 8099/2014 - Pr. Marco Feliciano, PSC/SP. Grifos meus). 
Por fim, é no PL 3044/2014, proposto pelo também pastor Hedekazu Takayama, que a defesa da influência dos valores familiares é estendida também sobre o tipo de ensino religioso a ser desenvolvido ambiente escolar.

É cediço que a renovação do conceito de ensino religioso é medida mais que necessária, e a participação do conselho de pais e mestres certamente assegurará a amplitude do diálogo, e $a$ participação dos pais na educação de seus filhos. Note-se que não se trata de mera "orientação" religiosa, mas sim de efetivar a participação dos pais com as "doutrinas" recebidas por ensinamentos a seus filhos. O ensino religioso e o estudo da religiosidade certamente é um mecanismo eficaz para desenvolver a cidadania e o próprio ser humano (PL 3044/2014 - Hedekazu Takayama, PSC/PR).

É interessante observar que o caráter facultativo atribuído pela Constituição Federal (BRASIL, 1988) é omitido na redação do artigo $3^{\circ}$ da lei proposta por Takayama: "O ensino religioso será ministrado dentro do horário normal de aula e sua carga horária integrará as horas previstas para o ano letivo". A ênfase na atuação familiar sobre os conteúdos e a intenção de tornar o obrigatório ensino religioso somados podem indicar uma tendência ao proselitismo religioso cristão.

Assim como as proposições ligadas à sexualidade, as iniciativas aqui apresentadas como exemplo da atuação parlamentar pró-inserção religiosa na educação não foram transformadas em lei. Seguem tramitando apensadas a outros projetos de teor semelhantes. Apesar disso, interessa observar a pouca importância dada pelos parlamentares à laicidade na esfera pública. As ideias de maioria moral, liberdade de crença e universalidade dos valores cristãos são utilizadas como justificativas em proposições religiosas pouco plurais. Estas estratégias se aproximam daquelas empregadas pela direita cristã estadunidense (LACERDA, 2019) e alimentam o ativismo religioso moralmente regulador (ALMEIDA, 2017).

Doutrinação (14) e homeschooling (13) aparecem no gráfico anterior respectivamente como o terceiro e o quarto maior interesse das proposições conservadoras voltadas para a educação na Câmara dos Deputados brasileira. As iniciativas destes blocos apresentam a preocupação com os tipos de conteúdo, valores e visões de mundo como argumentos em defesa tanto da reorientação (à direita) da educação escolar, como da instituição da educação em ambiente domiciliar. São exemplos dessas demandas os PLs 6001/2001 (Ricardo Izar, 
PTB/SP) e 246/2019 (Bia Kicis ${ }^{48}$ - PSL/DF). Separados por quase duas décadas, ambos os projetos atribuem ao ambiente escolar a implementação de práticas pedagógicas contrárias aos valores morais das famílias e, por isso, passíveis de doutrinação ideológica.

É nosso entendimento que o aprendizado em casa é um direito básico do cidadão. Atribuí-lo com exclusividade ao sistema escolar configura abuso de poder, ingerência indevida da autoridade na vida privada, desrespeito pela liberdade de ensinar e aprender. Obrigar a criança e ao adolescente a frequentar a escola é sujeitá-los à confrontação diária com a violência, o uso de drogas e, principalmente, uma orientação pedagógica nem sempre condizente com as convicções filosóficas, éticas $e$ religiosas de determinadas famílias (PL 6001/2001, Ricardo Izar - PTB/SP. Grifos meus).

...entendemos que é necessário e urgente adotar medidas eficazes para prevenir a prática da doutrinação política e ideológica nas escolas e a usurpação do direito dos pais a que seus filhos recebam a educação moral que esteja de acordo com suas próprias convicções (PL 246/2019, Bia Kicis - PSL/DF. Grifos meus).

Enquanto o primeiro defende a escolarização em ambiente doméstico, o segundo demanda ações eficazes contra a exposição dos alunos a supostas doutrinações praticadas nas instituições de ensino. Medidas diferentes para um posicionamento comum: a prioridade da família sobre a escola na formação das crianças e adolescentes, sobretudo quando a pedagogia escolar valoriza a diferença e os direitos humanos.. Além do evidente antagonismo em relação ao processo de escolarização, proposições deste tipo trazem apontamentos negativos relacionados à prática docente, aos conteúdos curriculares de algumas disciplinas e aos valores contrários a suas visões de mundo ideal (PENNA, 2018). É importante destacar que a proposta sobre educação domiciliar apresentada como exemplo foi arquivada e aquela relacionada à doutrinação encontra-se apensada a outros projetos que discutem os méritos do programa Escola Sem Partido. Voltarei a esse último mais

\footnotetext{
${ }^{48}$ A primeira autora do PL 246/2019 é a deputada Bia Kicis (PLS/DF), contudo, o texto conta com a assinatura de outros dezenove parlamentares: Chris Tonietto - PSL/RJ, Carla Zambelli - PSL/SP, Caroline de Toni PSL/SC, Gurgel - PSL/RJ, Carlos Jordy - PSL/RJ, Aline Sleutjes - PSL/PR, Luiz Philippe de Orleans e Bragança - PSL/SP, Léo Motta - PSL/MG, Alê Silva - PSL/MG, Coronel Armando - PSL/SC, Alexis Fonteyne - NOVO/SP, Kim Kataguiri - DEM/SP, Sóstenes Cavalcante - DEM/RJ
} 
adiante, no entanto, admito adiantar a afinidade dessas propostas com duas linhas de força discutidas por Almeida (2017): moral e interacionista.

Se na linha de força moral ocorre a pressão pela moralidade pública centrada em valores cristãos, na linha interacionista se dá o tensionamento das relações sociais estabelecidas em contextos polarizados moral e politicamente. Ao lançar mão de justificativas morais na defesa da instituição da educação domiciliar e da reestruturação curricular das escolas públicas e particulares em todo o país, a filiação à linha moralmente reguladora é explicitada e de fácil identificação. Já no que se refere aos antagonismos, a tentativa de eliminar o diferente, o diverso, o "não natural" segundo algumas visões de mundo, e a aposta no conflito entre os diferentes sujeitos do processo educacional permitem relacionar estas proposições à linha interacionista neoconservadora. É possível relacionar o lobby ${ }^{49}$ próhomeschooling também à linha econômica, dado o interesse de empresas e organizações atuantes na venda de materiais didáticos e manuais pedagógicos que permitam aos pais tutelarem o processo de aprendizagem de seus filhos (APPLE, 2003; LACERDA, 2019).

Por fim, o último bloco de interesse apresentado pelas proposições conservadoras é aquele que versa sobre o patriotismo/militarismo. Iniciativas alocadas nesse bojo trazem duas perspectivas: i. a defesa de uma educação cívica e moral inspirada no amor à pátria, e, ii. o ativismo pró-militarização escolar. Nesse bloco cinco textos foram considerados diretamente ligados ao universo educacional e um o utiliza como componente argumentativo. Os projetos de lei 5072/2005 (Carlos Nader, PL/RJ), 4887/2019 (Carla Zambelli, PSL/SP) e 4826/2019 (Julian Lemos (PMDB/PB) exemplificam essas demandas.

Já no que se refere à disciplina Educação Moral e Cívica, ajudará a conscientizar os jovens de sentimentos como o amor à pátria $\mathrm{e}$ aos seus símbolos, tradições, instituições e respeito aos vultos de sua história; bem como o amor à família, preservação do espírito religioso, da dignidade, da liberdade com responsabilidade, dos valores éticos e morais, de solidariedade humana e aprimoramento do caráter. Além de prepará-los como cidadãos

\footnotetext{
${ }^{49} \mathrm{O}$ termo lobby é comumente utilizado na política para definir o conjunto de sujeitos, empresas e organizações em associações que buscam exercer pressões e influência política sobre determinados assuntos. A atividade, regulamentada nos EUA e sem regulamentação no Brasil, é exercida pelos chamados lobistas. Disponível: https://politica.estadao.com.br/noticias/geral,lobby-entenda-o-quesignifica-e-o-que-e-permitido-fazer-no-brasil,70003302707. Acesso em: 21/06/2021.
} 
cumpridores de seus deveres e cientes de suas obrigações (PL 5072/2005 - CARLOS NADER, PL/RJ. Grifos meus)

o modelo cívico militar, a escola muda sua infraestrutura para atender ao programa, e também a gestão administrativa, que passa a ser feita pelos militares. Ademais, em regra, as propostas pedagógicas das escolas militares têm como objetivo preparar o aluno para a vida em sociedade, formar cidadãos que atuem com ética e cidadania, sendo guiados pelos valores e tradições da educação militar. Além da alta qualidade de ensino, as escolas militares também são reconhecidas pela disciplina e pelas regras de comportamento e vestimenta aplicadas aos alunos (PL 4887/2019 - CARLA ZAMBELLI, PSL/SP. Grifos meus).

Desta forma, a pretensão é apenas o consecutivo ateio de formas subliminar, velada ou mesmo ostensiva, da luta entre grupos distintos, que se materializam em textos jornalísticos, falsas expressões culturais, doutrinação escolar, atuações políticopartidárias dentre outras, sempre com a pseudo intenção da busca pela justiça social. Em nome desses "ideais" os adeptos dessa ideologia estão dispostos a tudo e já perpetraram toda a sorte de barbáries contra agentes do Estado que objetivaram neutralizar sua "causa" (PL 4826/2019 - JULIAN LEMOS, PMDB/PB. Grifos meus).

As proposições deste bloco temático compartilham, tais como os exemplos acima, a preocupação com a ordem, os valores religiosos e o amor à pátria, e militam a favor da implementação das tradições militares tanto no currículo, quanto na própria estrutura e gestão das instituições sociais em geral. Justificativas de ordem securitária (controle da violência escolar, do uso/tráfico de drogas na escola, contenção de grupos comunistas violentos entre outros) dividem espaço com aquelas de ordem moral (desenvolvimento do civismo e da disciplina comportamental) e compensatória (melhores índices e resultados em avaliações e concursos por parte de alunos de escolas militares). Discussões sobre a validade desses pressupostos à parte, é possível alocar proposições desse porte dentro da linha securitária apresentada por Almeida (2017) aplicadas à educação. Ações de cunho securitário, de modo geral, se referem a posturas repressivas e punitivistas por parte do Estado. Aplicadas à educação, as ações securitárias investem na militarização da gestão pública escolar e na idealização da ordem sobre a indisciplina. 
Um aspecto interessante observado durante a análise das proposições pró militarização ou inclusão de disciplinas de cunho cívico-moral são certas similaridades encontradas tanto nestes textos, quanto naqueles relacionadas à defesa do Ensino Religioso. O desenvolvimento da cidadania, do civismo, dos valores morais cristãos tidos como universais, o respeito à ordem e afins, figuram em ambos os blocos ora como objetivo, ora como justificativa. Essa sintonia é também apontada por Cunha (2014a), e, segundo autor, figura uma constante ao longo da história brasileira. A instrumentalização da escola pública via imposição de conteúdos religiosos e políticos-ideológicos resultaria então da fraca autonomia do campo educacional.

Sobre a frequência das proposições conservadoras ao longo dos períodos aqui discutidos (Figura 19), em que pese a longevidade de cada turno analisado (12 anos entre 2001-2012 e 7 anos entre 2013-2019), é possível observar que a pauta conservadora educacional cresceu em números absolutos e trocou de ênfase ao longo do tempo.

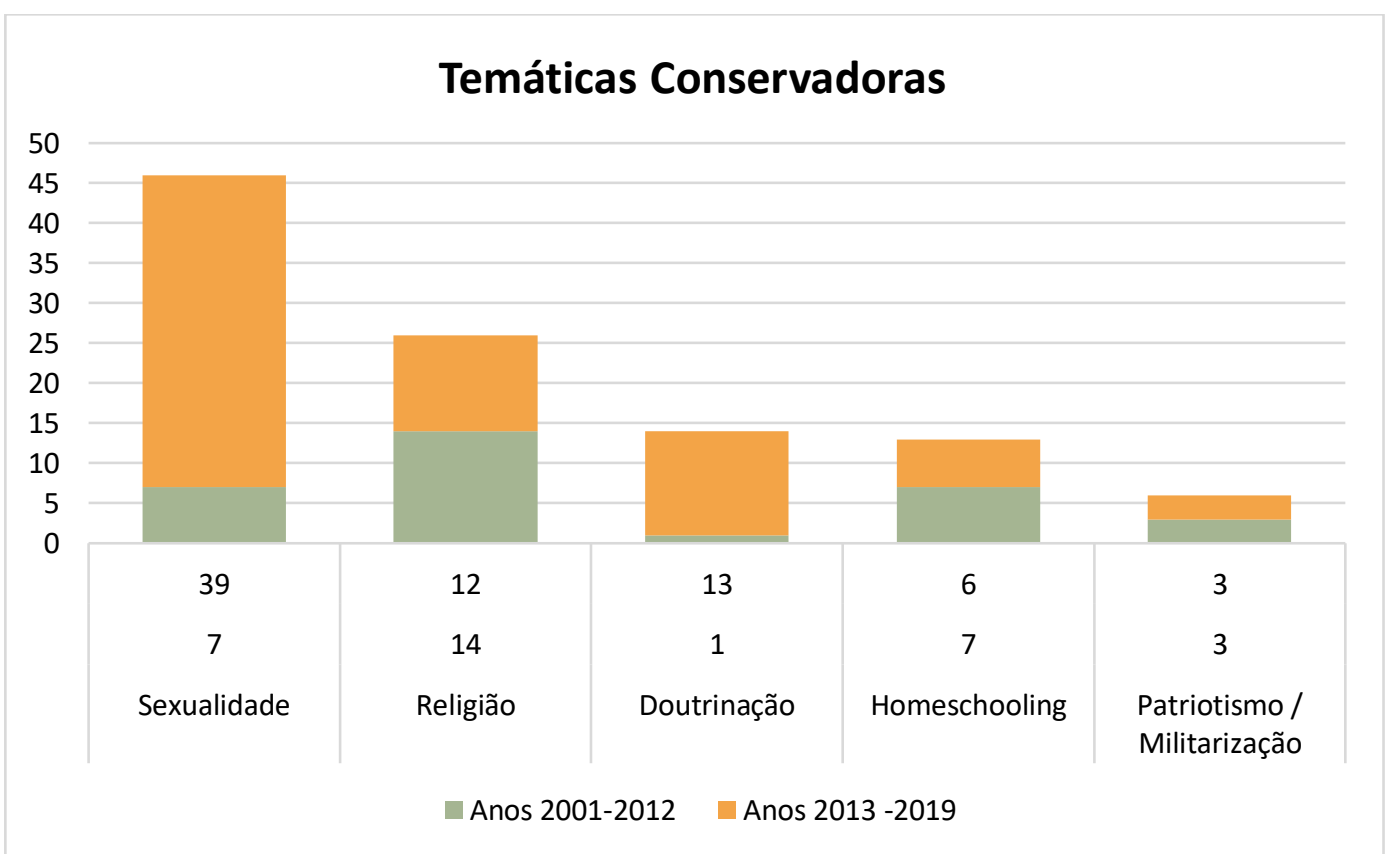

Figura 19: Número de proposições conservadoras segundo as temáticas abordadas divido por período analisado. FONTE (AUTORA, 2021).

As iniciativas relacionadas às demandas religiosas cristãs eram mais frequentes que as demais entre os anos 2001-2012 (14 iniciativas), seguidas por sexualidade (7) e homeschooling (7), patriotismo/militarização (3) e doutrinação (1). Após 2013 as proposições voltadas para a sexualidade (educação sexual e discussões de gênero) superam amplamente as demais (39). Iniciativas 
parlamentares de cunho religioso (12) e preocupadas com a doutrinação escolar (13) empatam em número de proposições. Aquelas voltadas para a educação domiciliar apresenta uma leve queda (6), enquanto patriotismo/militarização mostra-se constante (3).

A elevada expressão de demandas relacionadas à sexualidade e educação vai ao encontro dos achados apresentados por Lacerda (2019) que, ao pesquisar a atuação conservadora ao longo dos anos 2003-2015 relatou o avanço expressivo de proposições contra as questões de gênero e demandas LGBT após 2013 e 2014. A autora atribuiu esse avanço ao endurecimento conservador em reação às políticas públicas de reconhecimento e valorização da diversidade colocadas em pauta nas gestões petistas. O Programa Escola sem Homofobia é um exemplo dessa dinâmica reativa. Concebido como uma ferramenta de combate ao preconceito e não discriminação sexual nas escolas, o material formulado pelo MEC do ministro Fernando Haddad em 2011 consistia em um caderno e vídeos educativos que abordavam os conceitos de gênero, diversidade sexual, homofobia e outros.

O "Kit Gay", alcunha atribuída ao Programa pelo então Deputado Federal Jair Bolsonaro, foi alvo de intensa propaganda contrária e acusado de promover a promiscuidade, a pedofilia e a homossexualidade em espaço escolar. A bancada cristã se uniu contra o projeto e realizou 47 discursos contrários ao mesmo, segundo Lacerda (2019). A radicalização foi tamanha que o Governo Dilma recuou de sua implementação, apesar de afirmar posição contrária à homofobia. A tentativa de promover um diálogo plural e tolerante sobre sexualidade na educação por parte do Executivo levou a uma reação unificada por parte dos conservadores atuantes no Legislativo e na sociedade civil. Nesse momento a cruzada "anti-gênero" ganhou a força que o gráfico anterior indica. Das 42 proposições relacionadas à sexualidade, 7 são Projetos de Decreto Legislativo que visam sustar matérias que façam referência ao gênero e afins. Os PDCs 16/2015 (Pr. Marco Feliciano, PSC/SP), 30/2015 (Eros Biondini, PTB/MG) ${ }^{50}$ e 115/2015 (Alfredo Kaefer, PSDB/PR) buscam neutralizar:

\footnotetext{
${ }^{50}$ Apesar de o primeiro autor ser o deputado Eros Biondini (PTB/MG), outros 73 parlamentares assinam o documento: Fausto Pinato - PRB/SP, Josué Bengtson - PTB/PA, Walney Rocha - PTB/RJ, Flavinho - PSB/SP, Hugo Leal - PROS/RJ, Jhc - SD/AL, Leonardo Quintão - PMDB/MG, Andre Moura - PSC/SE, João Campos - PSDB/GO, Moroni Torgan - DEM/CE Evandro Gussi - PV/SP, Paulo Freire - PR/SP, Lincoln Portela - PR/MG, Evair de Melo - PV/ES, Celso Maldaner PMDB/SC, Major Olimpio - PDT/SP Subtenente Gonzaga - PDT/MG, André Fufuca - PEN/MA,
} 
a Resolução $\mathrm{n}^{\circ}$ 12, de 16 de Janeiro de 2015, da Secretaria de Direitos Humanos, da Presidência da República, que estabelece parâmetros para a garantia das condições de acesso $e$ permanência de pessoas travestis e transexuais - e todas aquelas que tenham sua identidade de gênero não reconhecida em diferentes espaços sociais - nos sistemas e instituições de ensino, formulando orientações quanto ao reconhecimento institucional da identidade de gênero e sua operacionalização (Texto de apresentação dos PDCs supracitados. Grifos meus)

Os PDCs 213/2015 (Professor Victório Galli, PSC/MT) e 214/2015 (Pastor Eurico, PSDB/PE) ${ }^{51}$ buscam, por sua vez, sustar a "Portaria $n^{\circ} 916$, de 9 de setembro de 2015, do Ministério da Educação, que Institui Comitê de Gênero, de caráter consultivo, no âmbito do Ministério da Educação". E, finalmente, os PDCs 122/2015 (Flavinho, PSB/SP) ${ }^{52}$ e 1094/2018 (Diego Garcia, PODE/PR) legislam sobre a chamada "ideologia de gênero" em documentos oficiais da educação.

José Carlos Aleluia - DEM/BA, Valdir Colatto - PMDB/SC, Marx Beltrão - PMDB/AL, Irmão Lazaro - PSC/BA, Diego Garcia - PHS/PR, Ronaldo Martins - PRB/CE, Pastor Eurico - PSB/PE, Missionário José Olimpio - PP/SP, Tenente Lúcio - PSB/MG, Professor Victório Galli - PSC/MT Nilton Capixaba - PTB/RO, Alan Rick - PRB/AC, Roberto Alves - PRB/SP, Ronaldo Nogueira PTB/RS, Leonardo Picciani - PMDB/RJ, Mendonça Filho - DEM/PE, Anderson Ferreira - PR/PE, Marcelo Aguiar - DEM/SP, Sóstenes Cavalcante - PSD/RJ, Givaldo Carimbão - PROS/AL, Marcelo Aro - PHS/MG,Delegado Éder Mauro - PSD/PA, Antônio Jácome - PMN/RN, Capitão Augusto PR/SP, Marcos Rogério - PDT/RO, Francisco Chapadinha - PSD/PA, Eduardo Bolsonaro - PSC/SP, Carlos Gomes - PRB/RS, Rogério Rosso - PSD/DF, Rodrigo Martins - PSB/PI, Vinicius Carvalho PRB/SP, Esperidião Amin - PP/SC, Renzo Braz - PP/MG, Antonio Bulhões - PRB/SP, Cleber Verde - PRB/MA, Luiz Lauro Filho - PSB/SP, Ricardo Tripoli - PSDB/SP, Ezequiel Teixeira - SD/RJ, Miguel Lombardi - PR/SP, Francisco Floriano - PR/RJ, Jair Bolsonaro - PP/RJ, Edmar Arruda PSC/PR, Nelson Marquezelli - PTB/SP, Jose Stédile - PSB/RS, Sérgio Moraes - PTB/RS, Raquel Muniz - PSC/MG, Uldurico Junior - PTC/BA, Jefferson Campos - PSD/SP, Brunny - PTC/MG, Gonzaga Patriota - PSB/PE, Júlio Delgado - PSB/MG, Paulo Foletto - PSB/ES, Luciano Ducci PSB/PR, Stefano Aguiar - PSB/MG, Roberto Sales - PRB/RJ.

${ }^{51}$ Apesar de ter a autoria principal atribuída ao deputado Pastor Eurico (PSDB/PE), outros 47 deputados assim o documento: Alan Rick - PRB/AC, Alberto Fraga - DEM/DF, Anderson Ferreira - PR/PE, Andre Moura - PSC/SE, Antonio Bulhões - PRB/SP, Aureo - SD/RJ, Capitão Augusto PR/SP, Carlos Andrade - PHS/RR, Carlos Gomes - PRB/RS, Celso Russomanno - PRB/SP, Diego Garcia - PHS/PR, Domingos Neto - PROS/CE, Elizeu Dionizio - SD/MS, Evandro Gussi - PV/SP, Ezequiel Teixeira - SD/RJ, Fábio Sousa - PSDB/GO, Fabricio Oliveira - PSB/SC, Flavinho PSB/SP, Francisco Floriano - PR/RJ, Geovania de Sá - PSDB/SC, Givaldo Carimbão - PROS/AL, Jair Bolsonaro - PP/RJ, Jefferson Campos - PSD/SP, Jhonatan de Jesus - PRB/RR, João Campos PSDB/GO, Júlia Marinho - PSC/PA, Leonardo Quintão - PMDB/MG, Marcelo Aguiar - DEM/SP, Marcelo Aro - PHS/MG, Marcos Rogério - PDT/RO, Missionário José Olimpio - PP/SP, Moroni Torgan - DEM/CE, Nilton Capixaba - PTB/RO, Osmar Terra - PMDB/RS, Pastor Franklin PTdoB/MG, Pr. Marco Feliciano - PSC/SP, Professor Victório Galli - PSC/MT, Roberto Alves PRB/SP, Rocha - PSDB/AC, Rogério Rosso - PSD/DF, Ronaldo Fonseca - PROS/DF, Rosangela Gomes - PRB/RJ, Silas Câmara - PSD/AM, Sóstenes Cavalcante - PSD/RJ, Stefano Aguiar PSB/MG, Tereza Cristina - PSB/MS, Vinicius Carvalho - PRB/SP

${ }^{52}$ Apesar da autoria principal ser atribuída ao deputado Flavinho (PSB/SP), outros 67 deputados assinam o documento: Nelson Marquezelli - PTB/SP, Evandro Gussi - PV/SP, Paulo Foletto - PSB/ES, Marcus Pestana - PSDB/MG, Luiz Carlos Hauly - PSDB/PR, Izalci - PSDB/DF, Moroni Torgan - DEM/CE, Goulart PSD/SP, Silas Câmara - PSD/AM, César Messias - PSB/AC, Tenente Lúcio - PSB/MG, Adilton Sachetti PSB/MT, Givaldo Carimbão - PROS/AL, Pr. Marco Feliciano - PSC/SP Eros Biondini - PTB/MG, Lincoln 
Ficam sustados os efeitos do Documento Final do CONAE 2014, assinado e apresentado pelo Fórum Nacional de Educação, em todas as suas disposições que contenham ou façam referência às expressões gênero, diversidade ou orientação sexual (PDC 122/2015 - Flavinho, PSB/SP. Grifos meus).

Fica sustada a Portaria ${ }^{\circ} 1.210$, de 20 de novembro de 2018, do Ministério da Educação, que homologa o Parecer CNE/CEB n ${ }^{\circ}$ 3/2018, da Câmara de Educação Básica, do Conselho Nacional de Educação, aprovado na sessão de 8 de novembro de 2018, que, junto ao Projeto de Resolução a ele anexo, propõe a atualização das Diretrizes Curriculares Nacionais para o Ensino Médio. (...) O referido documento apresenta conteúdo estranho, ao estipular que as propostas pedagógicas para o ensino médio contemplem a ideologia de gênero (PDC 1094/2018 - Diego Garcia, PODE/PR. Grifos meus).

É interessante observar a capacidade de aglutinação desses documentos. Alguns chegam a ultrapassar 50 assinaturas de autoria. Estes autores estão vinculados a diferentes partidos e unidades federativas, algo que aponta a potência e o espraiamento do tema dentro do bojo de ações neoconservadoras. Entre os argumentos mais comuns do ativismo contra a "ideologia de gênero" se encontram a defesa da família patriarcal como base da sociedade e sua fragilidade frente às investidas feministas e LGBT, bem como a necessidade de orientar a educação nacional de volta aos trilhos tradicionais e condizentes com os valores familiares. Características comuns às investidas neoconservadoras da direita cristã estadunidense (LACERDA, 2019). Tais paralelos e semelhanças apontam mais uma vez as proximidades e adaptações da ideologia conservadora ao contexto social brasileiro vigente.

Portela - PR/MG, Alan Rick - PRB/AC, Roberto Alves - PRB/SP, Ronaldo Martins - PRB/CE, Antonio Bulhões - PRB/SP, Rogério Peninha Mendonça - PMDB/SC, Jair Bolsonaro - PP/RJ, Márcio Marinho PRB/BA, Miro Teixeira - PROS/RJ, Júlio Delgado - PSB/MG, Joaquim Passarinho - PSD/PA, Sóstenes Cavalcante - PSD/RJ, Alexandre Serfiotis - PSD/RJ, João Rodrigues - PSD/SC, Jefferson Campos - PSD/SP, Ezequiel Teixeira - SD/RJ, Fábio Sousa - PSDB/GO, Walter Ihoshi - PSD/SP, Vitor Lippi - PSDB/SP, Eduardo Cury - PSDB/SP, Marcelo Aro - PHS/MG, Kaio Maniçoba - PHS/PE, Vitor Valim - PMDB/CE, Macedo - PSL/CE, Missionário José Olimpio - PP/SP, Francisco Floriano - PR/RJ, Geovania de Sá PSDB/SC, Diego Garcia - PHS/PR, Evandro Roman - PSD/PR, Carlos Gomes - PRB/RS, Esperidião Amin PP/SC, Fábio Mitidieri - PSD/SE, Hildo Rocha - PMDB/MA, Alceu Moreira - PMDB/RS, Alberto Filho PMDB/MA, Lelo Coimbra - PMDB/ES, Walter Alves - PMDB/RN, Hugo Motta - PMDB/PB, Veneziano Vital do Rêgo - PMDB/PB, Laudivio Carvalho - PMDB/MG, Cabuçu Borges - PMDB/AP, Luiz Lauro Filho - PSB/SP, Clarissa Garotinho - PR/RJ, Herculano Passos - PSD/SP, Leopoldo Meyer - PSB/PR, Heitor Schuch - PSB/RS, Fernando Coelho Filho - PSB/PE, Baleia Rossi - PMDB/SP, Marcos Rogério - PDT/RO, Evair de Melo - PV/ES, Fernando Francischini - SD/PR. 


\subsubsection{Iniciativas progressistas e seus interesses}

Sobre as proposições consideradas "progressistas" (Apêndice D) e suas temáticas de interesse (Figura, 20), quatro encaminhamentos foram identificados: sexualidade, educação pluralista (que engloba perspectivas plurais, democráticas e pró-diversidade), religião, oposição à militarização. Reitero que o critério utilizado para classificar as proposições como progressistas foi o compromisso com perspectivas educacionais laicas, plurais, de valorização das diferenças e dos direitos humanos. Assim como nas iniciativas conservadoras, o tema da sexualidade ocupou lugar expressivo de destaque. Das 65 iniciativas progressistas encontradas ao longo do período analisado, 35 eram relacionadas à sexualidade, 20 se referiam à educação em termos mais plurais, enquanto religião e oposição à militarização escolar apresentaram 6 e 4 cada uma respectivamente.

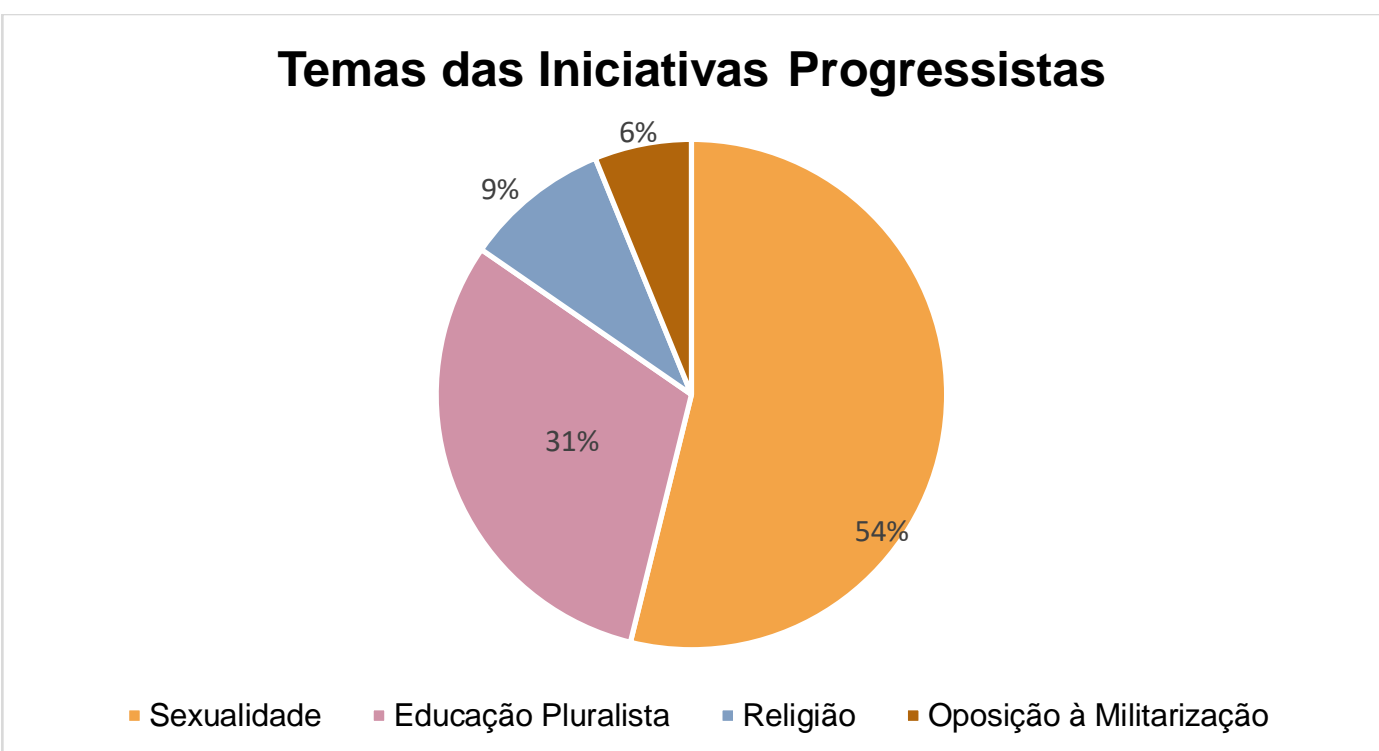

Figura 20: Temas das proposições relacionadas à consideradas progressistas encontradas entre 2001-2020

De acordo com a Figura (21), as demandas sobre o respeito à diversidade sexual e promoção da não discriminação sexual foram destaque nos dois períodos analisados. A busca por uma educação plural e tolerante também foi encontrada em ambos os períodos analisados, bem como iniciativas relacionadas à religião, mesmo 
que em menor volume. A única temática não encontrada no primeiro segmento de tempo analisado foi aquela que se opõe à militarização escolar. Cabe destacar que estas surgem em resposta ao PECIM, o decreto baixado por Jair Bolsonaro em 2019 que institui a criação de escolas cívico militares em todo o país.

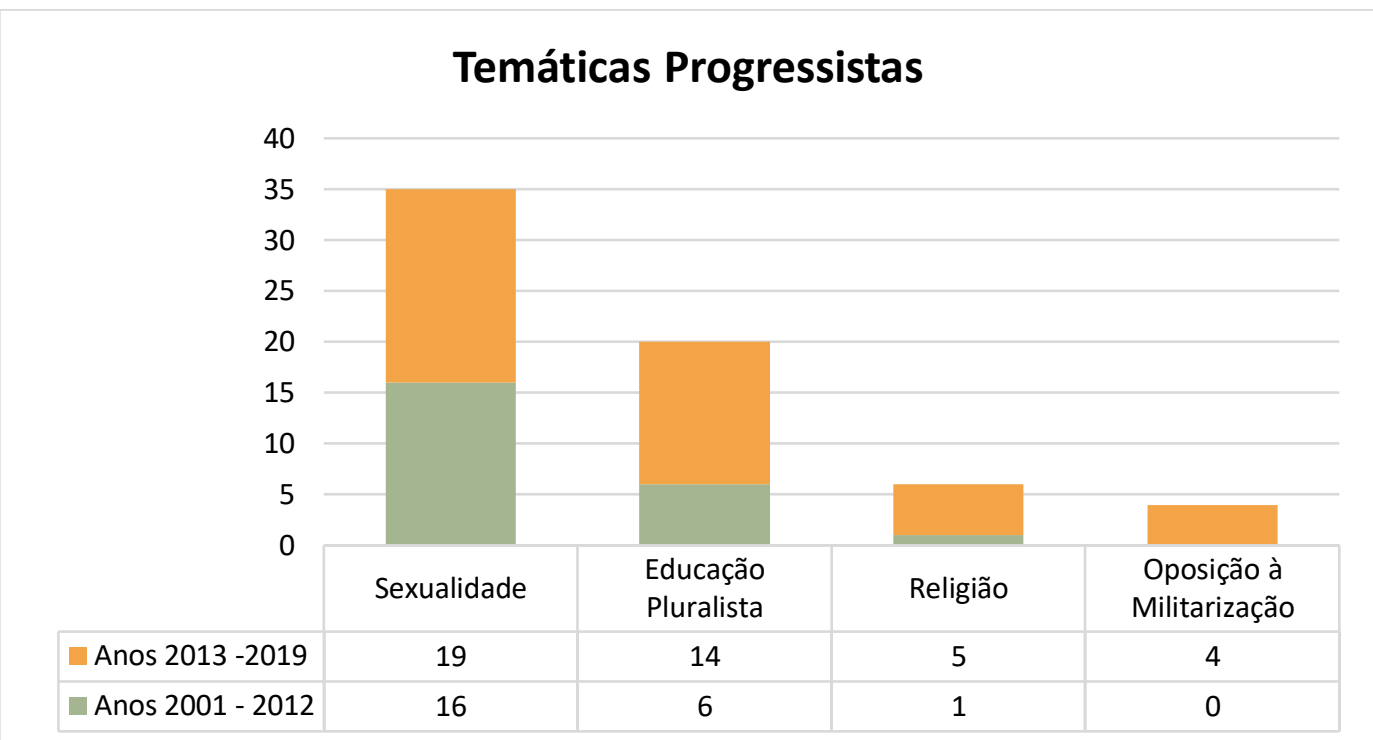

Figura 21: Frequência de proposições por tema divididas por período analisado

Ainda no que se refere à posição ocupada pelo universo educacional nessas proposições (Figura 22), é nítida a centralidade da educação em todas as categorias analisadas. Apenas os textos sobre sexualidade utilizam a temática educacional como um potente recurso argumentativo em pautas mais amplas, como as discussões sobre equidade de gênero na sociedade por exemplo. 


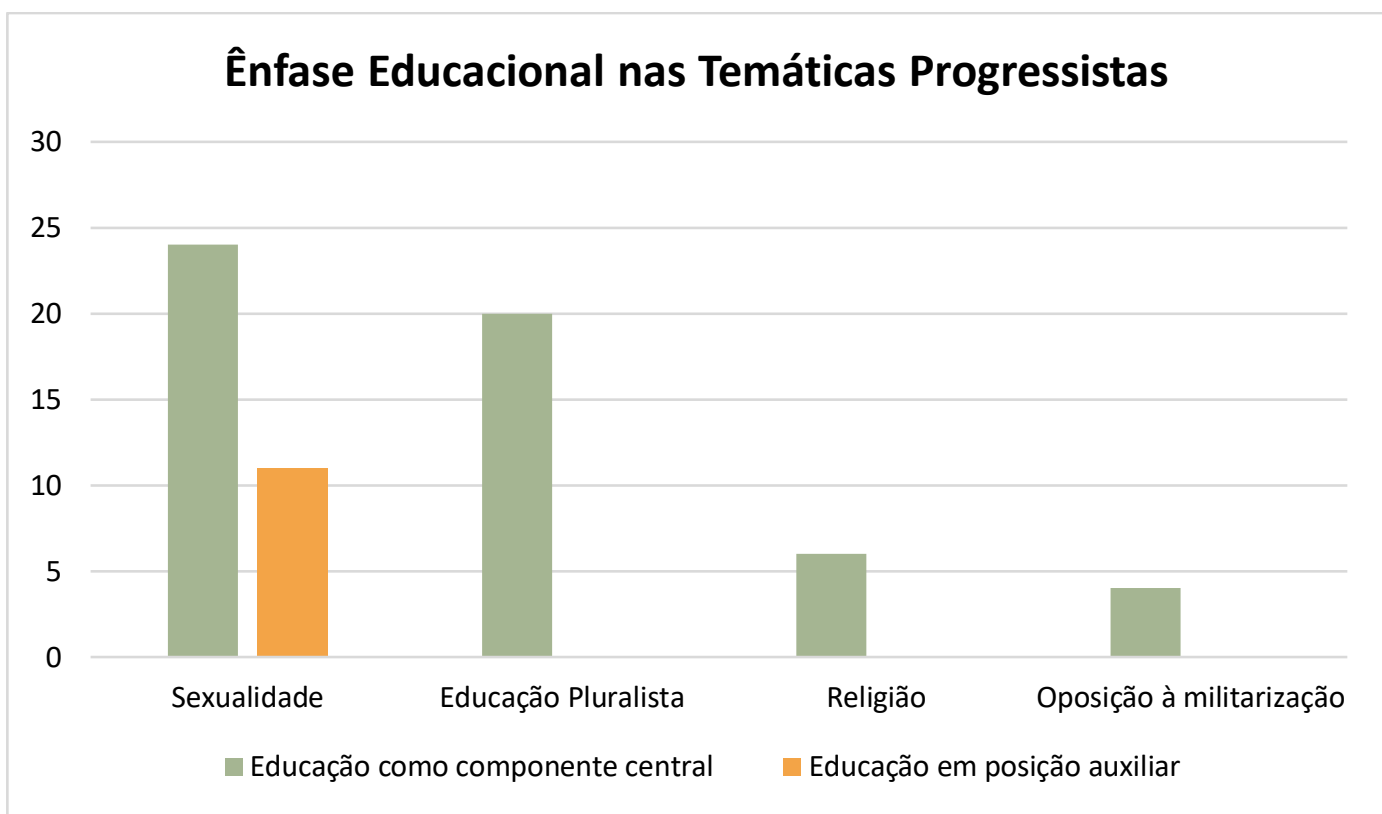

Figura 22: Posição ocupada pela educação nas temáticas de natureza progressistas analisadas. FONTE: AUTORA (2021).

Sobre o par sexualidade/educação, quatro tipos de direcionamentos foram encontrados: i. iniciativas voltadas para a educação sexual e promoção da saúde dos educandos, exemplificado através do PL 7/2003 (Iara Bernardi, PT/SP); ii. iniciativas voltadas ao combate da violência de gênero e discriminações de cunho sexual em unidades educacionais (PL 4318/2019, Aline Gurgel, PRB/AP); iii. medidas voltadas para a promoção da equidade de gênero na sociedade em geral, como é o caso do PL 4559/2004 (autoria do Poder Executivo e transformado em Lei Ordinária 11340/2006), e, por fim, iii. medidas voltadas para o combate à discriminação LGBT PL 3741/2019 nos diferentes contextos sociais (Fernanda Melchionna, PSOL/RS).

As ações voltadas para a educação e saúde sexual em ambiente escolar buscam informar através do diálogo e sem apelar para discursos de culpabilização. No texto da deputada Iara Bernardi, a educação escolar é entendido como algo que

...informe, mas também favoreça a reflexão e problematização de temas polêmicos e importantes, que trabalha também com a compreensão de valores sociais, privilegie a discussão da questão de gênero, com ampla liberdade de expressão, num clima de respeito, é que se consegue ir além da aquisição de informações e mudar comportamento. (...) como principal objetivo possibilitar que crianças e adolescentes possam fazer escolhas na área da sexualidade com responsabilidade e sem culpa, sem correr riscos de uma gravidez indesejada e de doenças sexualmente transmissíveis, obrigatoriamente oferecidos pelas 
escolas, mas, facultativamente frequentado pelos alunos (PL 7/2003. Grifos meus).

As discussões relacionadas à equidade de gênero na educação podem ser explicitadas através do PL 4559/2004, posteriormente transformado em Lei Ordinária 11.340/2006, conhecida como a Lei Maria da Penha.

As desigualdades de gênero entre homens e mulheres advêm de uma construção sócio-cultural que não encontra respaldo nas diferenças biológicas dadas pela natureza. Um sistema de dominação passa a considerar natural uma desigualdade socialmente construída, campo fértil para atos de discriminação e violência que se "naturalizam" e se incorporam ao cotidiano de milhares de mulheres. As relações e o espaço intra-familiares foram historicamente interpretados como restritos e privados, proporcionando a complacência e a impunidade (PL 4559/2004 - Poder Executivo).

Apesar de discutir a violência doméstica, o projeto de lei em questão vê na educação um espaço potente para discussões sobre gênero orientadas pelos direitos humanos e pela percepção não naturalizada das desigualdades. Dessa forma, busca

IX- A promoção de programas educacionais formais e nãoformais que disseminem valores éticos, do irrestrito respeito à dignidade da pessoa humana e dos direitos das mulheres.

$\mathrm{X}$ - Privilegiar nos currículos escolares, em todos os níveis, de conteúdos relativos aos direitos humanos, à equidade de gênero e à violência doméstica e familiar contra a mulher (PL 4559/2004 - Poder Executivo. Grifos meus).

Nesse sentido, inspirada pela Lei Maria da Penha, a Deputada Aline Gurgel propõe a instituição de um campanha educacional em todo território nacional adaptada ao público em idade escolar sobre violência em relações afetivas.

Foi identificado que a violência no namoro é um problema que afeta um grande número de jovens e tem recebido pouca atenção do poder público. Quando a violência se instala no cotidiano das relações afetivas durante a adolescência, seus efeitos sobre o desenvolvimento dos valores, padrões e hábitos são devastadores. (...) o objetivo principal [da proposta] é sensibilizar e mobilizar jovens e adolescentes, e quando possível a própria família, a discutir a problemática da violência e propor ações preventivas, antes que esta se instale na percepção moral do indivíduo (PL 4318/2019, Aline Gurgel, PRB/AP). 
Por fim, o PL 7180/2019 ${ }^{53}$ visa o combate à violência contra LGBTs através da educação. Em seu texto, fica estabelecida a criação do Programa Escola sem Discriminação, que prevê

\begin{abstract}
Art. $1^{\circ}$... a formação de professores, diretores de escola e gestores das Secretarias de Educação de estados e municípios para o combate à violência contra lésbicas, gays, bissexuais, travestis, transexuais, intersexuais e quaisquer outras pessoas que sofram discriminação por sua identidade de gênero e orientação sexual (LGBTI+) nas instituições de ensino públicas. Art. $2^{\circ} \mathrm{O}$ programa tem como objetivo qualificar os professores dos ensinos fundamental e médio de escolas municipais, estaduais e federais e demais profissionais das instituições de ensino para que possam combater o preconceito e a violência contra pessoas LGBTI+ (PL 7180/2019 - Fernanda Melchionna, PSOL/RS)
\end{abstract}

A dinâmica reativa apontada durante a análise das proposições conservadoras quanto à sexualidade ganha clareza quando à luz das iniciativas progressistas. Enquanto as progressistas buscam garantias cidadãs e direitos constitucionais para minorais e populações em situação de vulnerabilidade, as pautas conservadoras não entendem estes sujeitos como cidadãos plenos de direito. O avanço das políticas de reconhecimento e redistribuição acionaram os alarmes de pânico daqueles grupos confortáveis com a naturalização das desigualdades de todos os tipos, pois novas possibilidades de existência e, mais especificamente neste caso, de sexualidade ameaçam as certezas conservadoras e exigem retaliação. (ALMEIDA, 2017; BURITY, 2018). A polarização em torno desse tema se materializa não somente pelo alto valor simbólico do mesmo, mas também pelo seu poder regulação dos corpos, afetos e comportamentos dos indivíduos (CUNHA, 2017).

Sobre as pautas relacionadas à educação pluralista, os PL 6005/2016 (Jean Wyllys - PSOL/RJ) e 502/2019 (Talíria Petrone - PSOL/RJ) instituem, respectivamente, os Programas "Escola Livre" e "Escola sem Mordaça" em oposição aos ideais autoritários do "Programa Escola sem Partido", já mencionado. Em seus textos os deputados advogam a necessidade de um processo educacional pautado pelo livre pensamento, laicidade, direitos humanos, pluralidade de ideias e

\footnotetext{
53 Apesar de ter autoria principal atribuída à deputada Fernanda Melchionna (PSOL/RS), o documento é assinado pelos deputados: David Miranda (PSOL/RJ) e Sâmia Bonfim (PSOL/SP).
} 
orientado à emancipação, tolerância e superação de preconceitos de quaisquer tipos. Estes ideais são expressos nos seguintes trechos:

Art. $2^{\circ}$. São vedadas, em sala de aula ou fora dela, em todos os níveis e modalidades de educação da Federação, as práticas de quaisquer tipos de censura de natureza política, ideológica, filosófica, artística, religiosa elou cultural a estudantes e docentes, ficando garantida a livre expressão de pensamentos $e$ ideias, observados os direitos humanos e fundamentais, os princípios democráticos e os direitos e garantias 3 estabelecidos no artigo $1^{\circ}$ da presente Lei, na Constituição Federal e nos tratados internacionais de direitos humanos dos quais o Brasil é signatário (PL 6005/2016 - Jean Wyllys, PSOL/RJ. Grifos meus).

$2^{\circ}$. As liberdades de expressão e manifestação serão garantidas a docentes e estudantes, permitindo-se o conhecimento de diferentes pontos de vista e o debate democrático e respeitoso de ideias e visões de mundo, sem confundir liberdade de expressão e manifestação do pensamento com preconceito, discriminação e/ou discursos de ódio (PL 502/2019 - Talíria Petrone, PSOL/RJ. Grifos meus).

Autores como Rosa (2018) e Penna (2018) apontam que, em virtude do crescimento em número e adesão de pautas autoritárias voltadas para a educação, é preciso disputar os sentidos atribuídos ao processo de escolarização e seus sujeitos. A gestão democrática e o diálogo entre os diferentes devem surgir como estratégias e educacionais empregadas na superação dos antagonismos que adentram a escola. Se o ambiente escolar se torna polarizado a ponto de fomentar vinganças, fobias e pânico, tal como aponta Almeida (2017), os docentes são vistos como potenciais abusadores e os educandos como público cativo passível de doutrinação, os sentidos atribuídos a escola se perderam e devem ser retomados. As pautas progressistas também apontam nessa direção.

Já sobre as questões religiosas e sua relação com a educação, dois Projetos de Lei se destacam no campo progressista: a criminalização da discriminação contra aqueles que fazem uso de vestimentas e aparatos religiosos (PL 979/2015 - Wadson Ribeiro, $\mathrm{PCdoB} / \mathrm{MG}$ ) e a defesa do ensino religioso em sua vertente não confessional (PL 9208/2017 - Jean Wyllys, PSOL/RJ). Enquanto o primeiro utiliza um caso de discriminação violenta ocorrida em ambiente escolar para sustentar sua proposição, o segundo o faz na defesa constitucional da liberdade de crença e da laicidade. Essas defesas podem ser vistas nos trechos destacados: 
No Brasil das últimas décadas, casos de intolerância religiosa vêm crescendo sendo que em muitos deles a causa tem sido o uso desses sinais externos de pertencimento religioso em espaço público. Recentemente, a imprensa noticiou dois episódios que retratam bem a situação de coibição de direitos. Na cidade do Rio de Janeiro, um estudante de doze anos foi impedido de entrar na escola municipal Francisco Campos em que estudava por usar colares (guias) de candomblé. O caso foi amplamente divulgado pela mídia. Segundo sua família, o menino já era vítima de preconceito há algum tempo, inclusive tendo sido impedido de entrar na escola pela própria diretora do estabelecimento (PL 979/2015 - Wadson Ribeiro, PCdoB/MG. Grifos meus).

A escola pública deve ser o espaço da pluralidade e da isenção, onde alunos e alunas que provém de famílias de diferentes credos (ou de nenhum credo) possam aprender a pesquisar e se apropriar de conhecimentos, também, sobre o fenômeno religioso, em vez de que seja imposto a eles um determinado tipo de fé. Quando as escolas públicas se transformam em igrejas cristãs, o que acontece com os alunos e alunas que são judeus, muçulmanos, espíritas ou do candomblé? E os que são ateus ou agnósticos? O que aconteceria a alunos cristãos se, na escola, fossem doutrinados em alguma dessas outras crenças? Onde fica a liberdade de consciência e de crença que a Constituição Federal protege? (PL 9208/2017 - Jean Wyllys, PSOL/RJ. Grifos meus).

Iniciativas desse porte trazem novos elementos antes silenciados pelas pautas conservadoras: o espaço às demais religiões, sobretudo às não cristã. Se a base moral religiosa é fundamentalmente cristã (católica e evangélica), os demais credos religiosos, especialmente aqueles de oriundos de matrizes africanas, são subalternizados e apagados. Dentro do discurso de maioria moral, os credos divergentes e os não credos são silenciados, como afirma Almeida (2019).

Quando o assunto é a oposição à militarização escolar, todas as iniciativas encontradas foram propostas em 2019. Duas são Projetos de Lei que legislam sobre a gestão de escolas cívico-militares, e as outras duas são Projetos de Decretos Legislativo que objetivam sustar o Decreto 10.004/2019 que institui o PECIM. Apresento o PL 4938/2019 (Mário Heringer - PDT/MG) e PDC 649/2019 (João Daniel - PT/SE) como exemplos:

É mister que se entenda que escolas públicas regulares não podem ser convertidas em escolas vocacionais militares, ao arrepio da Lei e dos princípios constitucionais, como hoje ocorre em várias experiências concretas. As escolas militares pertencentes às Forças Armadas, às polícias militares e aos corpos de bombeiros são escolas vocacionais. Escolas 
vocacionais se diferem da escola regular por possuírem projetos político-pedagógicos especializados, voltados para o treino e a capacitação em área específica. Ainda que se encontrem submetidas à legislação educacional como quaisquer escolas, as escolas vocacionais são especializadas e especiais, daí sua condição de excepcionalidade. As famílias optam livremente pela matrícula em escolas vocacionais por desejarem exatamente aquele tipo de educação para seus filhos. Trata-se de uma escolha voluntária, jamais uma imposição do Estado (PL 4938/2019 Mário Heringer, PDT/MG. Grifos meus).

Incorre em exorbitância do poder regulamentar o Decreto em epígrafe ao pretender instituir programa de governo que retira dos profissionais da educação atribuições funcionais que lhes são estabelecidas em lei e as transfere para profissionais da defesa que não possuem os requisitos mínimos para o exercício da gestão escolar, nos termos do art. 61 da LDB (PDC 649/2019 João Daniel, PT/SE).

Aqui a demanda é reativa à nova hegemonia criada pela ascensão do conservadorismo ao poder. Se durante as gestões petistas eram os deputados de orientação conservadora que buscavam sustar políticas públicas progressistas, a dinâmica se inverte com a eleição de Jair Bolsonaro à Presidência da República. A defesa da militarização da gestão escolar, segundo Ricci (2019), se faz a partir de pressupostos enganosos: a ideia de que a disciplina militar acabará com a violência escolar e a defesa da qualidade do ensino em escolas vocacionais militares. Para o autor, aqueles que defendem a gestão escolar militarizada ignoram a raiz do problema da violência: a desigualdade social. Sobre a crença de que a militarização salvará os números de aprovação em avaliações externas e concursos de acesso à universidade, o autor aponta as escolas cívico-militares não contarão com a seleção prévia de candidatos portadores de capital social acumulados e habitus escolar favoráveis ao processo de escolarização.

\subsubsection{Iniciativas ambíguas e seus interesses}

As iniciativas ambíguas são identificadas como tal por possuírem textos pouco claros em relação à sua filiação ideológica e/ou articularem pressupostos considerados progressistas em proposições que deixam margem de dúvidas quanto a sua aplicação prática (Apêndice E). Porém a leitura das proposições e sua análise 
frente ao referencial teórico permitem entender que os objetivos e possíveis implicações das iniciativas podem evidenciar sentidos menos explícitos na redação dos textos. Assim, mesmo entre as demais categorias, é possível entender o quadro de atuação conservadora como um espectro em constante construção entre polos considerados mais ou menos conservadores/progressistas.

Nesse sentido, 17 textos foram considerados ambíguos. A maioria versa sobre aspectos religiosos da vida em sociedade (12 iniciativas), um número menor se ocupa de questões voltadas para a sexualidade em contextos escolares, especialmente o combate à violência sexual infantil (4) e uma única proposição pauta a autoridade familiar em ambiente escolar (1). De acordo com esses achados, é possível destacar que a educação ocupa um lugar de menor centralidade dentro dessa categoria, embora figure como um componente argumentativo em destaque nas justificativas apresentadas.

No que refere ao bloco de maior expressão, o direito constitucional à crença religiosa surge articulado ao conceito de laicidade ocorrem em iniciativas parlamentares que operam em duas frentes: i. propostas de alteração ou mesmo impedimento de datas de realização de concursos públicos e processos seletivos em dias considerados santos para religiosos e ii. propostas de criação de estatutos de liberdade religiosa. Nesses quesitos se encaixam, respectivamente, os PL 4354/2016 e 4356/2016, ambos assinados pelo deputado Átila Alexandre Nunes (PSL/RJ).

A inviolabilidade da liberdade de consciência, de crença e de culto constitui a resposta política adequada aos desafios do pluralismo religioso, permitindo desarmar o potencial de conflito entre as várias concepções religiosas, motivo pelo qual o Brasil, mesmo sendo um país com a maior população católica no mundo, sempre adotou o livre exercício de qualquer preceito religioso. Não é aceitável que dentro deste contexto de liberdade religiosa, uma pequena parcela de candidatos sejam prejudicados por não poderem realizar suas provas no sábado, por exemplo, como nos casos dos judeus e dos adventistas, que consideram o sábado como um dia sagrado, de descanso e meditações, onde qualquer atividade laborativa é permanentemente proibida (PL 4354/2016, Átila Alexandre Nunes, PSL/RJ).

O presente projeto visa reforçar o debate e a busca de solução para esta questão tão pertinente, visando promover o respeito entre as diversas crenças, que há de ser o objetivo maior daqueles que defendem a verdadeira democracia, onde o respeito às diferenças religiosas seja cumprido pela sociedade, mantendo-se o Estado laico para dirimir de forma imparcial todas 
as questões que forem pertinentes à matéria, pelo que conto com $\mathrm{o}$ apoio dos meus nobres pares para sua devida aprovação (PL 4356/2016, Átila Alexandre Nunes, PSL/RJ).

De acordo com os critérios utilizados para classificar as proposições em conservadoras e progressistas utilizados nesta tese, tais textos, assim como os demais integrantes deste bloco temático, não apresentam elementos conclusivos que permitam alocá-los em uma ou outra categoria. Acredito que tal dificuldade se relacione às disputas em torno do conceito de laicidade. Para Mariano (2011), as interpretações divergentes sobre o que vem a ser um Estado laico, assim como o sobre papel ou lugar da religião na sociedade, decorrem, em grande medida, dos diferentes fundamentos utilizados pelos grupos que as utilizam. As diferentes agendas políticas e visões de mundo, as bases epistemológicas, as posições e interesses sociais e institucionais influenciam quanto aos limites e potenciais defendidos. Em última análise, para Mariano, atribuir características e delimitar funções ao Estado laico implica necessariamente legitimar o tipo de atuação religiosa que permitida nos espaços públicas e esferas de poder.

Vale destacar que no caso da flexibilização das datas de concursos públicos o Plenário do Supremo Tribunal Federal em novembro de 2020 firmou entendimento de que, dentro da razoabilidade e isonomia, a Administração Pública deve garantir mudanças de data, horário e locais de provas em motivos de crenças religiosas dos candidatos. Bem como a garantia de alternativas a servidores em estágio probatório de realização de suas funções de acordo com suas crenças religiosas.

Apesar da vitória da tese majoritária defendida pelo ministro Luiz Edson Fachin de que "a separação entre Igreja e Estado não pode implicar o isolamento daqueles que guardam uma religião na sua esfera privada", acompanhada pelos ministros Luís Roberto Barroso, Alexandre de Moraes, Rosa Webber, Luiz Fux e Ricardo Lewandowski, a decisão não foi unânime. Os ministros Dias Toffoli, Gilmar Mendes e Kássio Nunes Marques defenderam o entendimento de que adequar a máquina pública às necessidades e restrições impostas por crenças religiosas de um grupo específico. Nas palavras de Gilmar Mendes, tal situação não seria razoável, pois a Administração Pública "não deve ficar à mercê de particularidades de cada um dos candidatos. tal situação pode conduzir à 
inviabilidade do concurso e afetar o interesse de toda a coletividade" (VALENTE, $2020)^{54}$.

Sobre os textos relacionados à sexualidade, todos versam sobre o combate ao abuso e exploração sexual na infância e na adolescência em contextos escolares. Tais proposições foram consideradas ambíguas pois, apesar de defenderem uma temática relevante para a formação da sexualidade saudável dos educandos, não adotam discussões e proposições compatíveis com a complexidade do assunto. Em meu entendimento tais documentos não podem ser considerados plenamente conservadores, pois utilizam em suas justificativas a noção de que a escola ocupa um lugar importante na educação sexual dos jovens, capacitando-os ao entendimento sobre seus corpos. Entretanto, não podem ser considerados plenamente progressistas, pois não buscam aprofundar discussões e apenas instituem a inserção de alertas e canais de denúncia, como é o caso do texto apresentado pelo Deputado Julian Lemos.

Uma parcela dos casos de abuso sexual, por exemplo, são descobertos no meio escolar. Através da observação da mudança de comportamento da vítima por professores e profissionais da educação. Este assunto delicado exige atenção especial, o que faz com que apresentamos a coeva ideação legal, buscando fazer com que o próprio Ministério da Educação divulgue e propague esse importante meio de comunicação, objetivando assim, um resultado positivo quanto a denúncias e uma coibição desta abominável prática (PL 2983/2019, Julian Lemos - PSL/SP. Grifos meus).

Ou ainda, não apresentam de maneira suficientemente claras aos pressupostos norteadores das campanhas educativas que pretendem estabelecer.

Alguns especialistas afirmam que, quando a escola promove explicações e ações de formação sobre educação sexual, há uma baixa probabilidade de gravidez precoce e um pequeno índice de doenças sexualmente transmissíveis. É importante, outrossim, que a adolescente comece os procedimentos médicos necessários, bem como receba suporte psicológico para tanto, tão logo descubra a gravidez, com objetivo de alcançar o cuidado pleno com a saúde da menor, bem como sua prole (PL 108103/20198, Mariana Carvalho, PSDB/RO. Grifos meus).

\footnotetext{
${ }^{54}$ Supremo Tribunal Federal decide pela flexibilização de datas de concurso por motivos religiosos. Disponível em: https://www.conjur.com.br/2020-nov-26/supremo-decide-flexibilizar-dataconcurso-motivo-religioso. Acesso em 19/05/2021.
} 
No caso do PL 10813/2019 que visa a criação de um Programa Nacional de Prevenção à Gravidez Precoce há um destaque a se fazer, o texto traz a redação quase exata do PL 166/2011 de autoria do Deputado Felipe Bornier. Considerado conservador e apresentado nas discussões sobre a abordagem temática conservadora sobre a sexualidade, o projeto de lei original traz em seu último parágrafo a afirmação de que prevenir os casos precoces de gestação partem de um objetivo maior: a preservação dos valores familiares. Para Bornier, "famílias desajustadas criam indivíduos desajustados”. Em sua proposição, a Deputada Mariana Carvalho suprime esse parágrafo. Não há indicativos de como a escola deve atuar, o tipo de campanha educacional esperada ou a natureza do discurso a ser adotado nela.

Dentro do espectro analisado é possível afirmar que essas proposições, apesar de consideradas ambíguas, ocupam um espaço entre aquelas consideradas progressistas e as conservadoras. Estas proposições avançam em relação àquelas que atribuem apenas à família o poder de tratar assuntos dessa natureza, ignorando de maneira intencional ou não o fato de que a maior parte dos abusos sexuais infantis ocorrem em ambiente intrafamiliar. Entretanto, é possível fazer um contraponto: poderíamos dizer que essas proposições teriam um teor supostamente neutro procurando ocupar o espaço daquelas mais comprometidas com reflexões plurais que ultrapassam as questões sobre segurança e defesa dos vulneráveis? Entendo que não, pois abordar o fenômeno da sexualidade e, especificamente nos casos de abuso sexual, de maneira ética e empoderada no ambiente escolar exige abordá-lo em sua completude sociocultural atravessada por relações de poder e demandas por equidade de gênero (LANDINI, 2011).

A possibilidade de instrumentalização de textos redigidos sem marcas explícitas de bandeiras conservadoras e considerados ambíguos aos interesses conservadores figura como uma estratégia retórica desses grupos, pois mascara as marcas ideológicas mais radicais e torna o discurso mais palatável à sociedade como um todo. Dentro do espectro de posicionamentos e natureza das proposições o texto apresentado por Helio Lopes, apoiador e amigo de Jair Bolsonaro, se aproxima mais dessa estratégia do que qualquer outro. O último texto considerado ambíguo versa sobre a necessidade de permissão por escrito dos pais ou responsáveis para participação de menores de dezesseis anos em protestos e manifestações durante os 
horários da aula. Ao iniciar sua argumentação com o expresso entendimento de que o direito à reunião e liberdade de manifestação é uma garantia constitucional, o texto passa a falar sobre a preocupação com alunos nessa situação.

$O$ direito à reunião é consagrado pela Constituição Federal de 1988 e inquestionável e a liberdade de manifestação e reunião devem ser sempre garantidas. No entanto, é responsabilidade dos pais ou responsáveis zelarem pelos cuidados com suas crianças e adolescentes. Não é razoável que estudantes de menos de dezesseis anos, durante o horário de aula, fiquem desassistidos e indevidamente desacompanhados em manifestações, protestos, reuniões públicas ou congêneres e, fora do horário escolar, sem a autorização por escrito de seus pais (PL 5854/2019, Hélio Lopes, PSL/RJ).

Embora redigido de maneira curta, supostamente neutra e manifestamente preocupada com o bem-estar dos estudantes, o documento força o entendimento de que professores e instituições escolares levam estudantes para manifestações em horários de aula a despeito da vontade dos pais. Não sem motivo, essa proposição corre apensada a projetos de lei explicitamente conservadores que versam sobre a criminalização da doutrinação docente, como é o caso do PL 9557/2008 de autoria do Deputado Jhonatan de Jesus (PRB/RR).

Em síntese, o levantamento quantitativo de iniciativas parlamentares ao longo dos últimos 20 anos permitiu observar que o conservadorismo educacional em torno de pautas como a sexualidade, a religião, a doutrinação ideológica, o homeschooling e a militarização/patriotismo, cresceu ao longo do período analisado (2001-2019) com ênfase acentuada após 2013, muito embora o campo progressista busque propor, em menor frequência, textos de caráter plural e mais preocupados com perspectivas educacionais empoderadoras em resposta. É interessante observar que textos considerados ambíguos podem tender mais ou menos ao progressismo/conservadorismo e lançar mãos de estratégias e subterfúgios a fim de pautar seus interesses.

Antes de analisar de apresentar os achados referentes aos demais materiais analisados acredito ser necessário apontar os principais agentes envolvidos nas proposições discutidas e suas relações com diferentes blocos temáticos discutidos. É ao perfil dos principais protagonistas a atuação parlamentar apresentada que passo a seguir. 


\subsubsection{Perfil dos protagonistas da atuação parlamentar: filiações e articulações}

Ao longo das últimas páginas busquei apresentar e discutir os principais números e temáticas associados à atuação parlamentar frente a um contexto de avanço neoconservador. Agora passo a discutir os principais protagonistas dessa atuação. No que se refere a principal autoria das proposições, a grande maioria tem como primeiro autor um homem em todas as categorias investigadas (Quadro 8).

\begin{tabular}{cccc}
\hline & Conservadoras & Progressistas & Ambíguas \\
\hline Autoria & $4(3,8 \%)$ & $17(26,2 \%)$ & $1(20,0 \%)$ \\
Feminina & & & \\
\hline Autoria & $101(96,2 \%)$ & $48(73,8 \%)$ & $4(80,0 \%)$ \\
Masculina & & & \\
Total de & 105 & 65 & 5 \\
Propostas & & &
\end{tabular}

Quadro 8: Percentual de autoria feminina segundo a natureza das proposições. FONTE: AUTORA (2021).

Quanto à filiação partidária dos autores principais das propostas consideradas conservadoras (Figura 23), o PSC - Partido Social Cristão - foi aquele que apresentou maior protagonismo (23 iniciativas), seguido do PSL (14 iniciativas) e PMDB/MDB (8 sob o nome Partido do Movimento Democrático Brasileiro e 1 como Movimento Democrático Brasileiro), para citar aqueles que mais pontuaram. Tais achados não foram surpreendentes dada o ativismo moral religioso estruturante do primeiro colocado e as agendas políticas dos outros dois partidos. Enquanto o PSL foi o partido no qual Jair Bolsonaro disputou e venceu a eleição presidencial de 2018 e aumentou de maneira expressiva o número de cadeiras na Câmara dos Deputados e passou a $2^{\mathrm{a}}$ maior bancada, ficando atrás apenas do PT. O PMDB, que voltou ao nome original em 2017, MDB, por sua vez, 
é visto como um partido estratégico e pragmático, que por não possuir uma rígida postura ideológica atrai perfis de todo tipo, incluindo-se conservadores ${ }^{55}$.

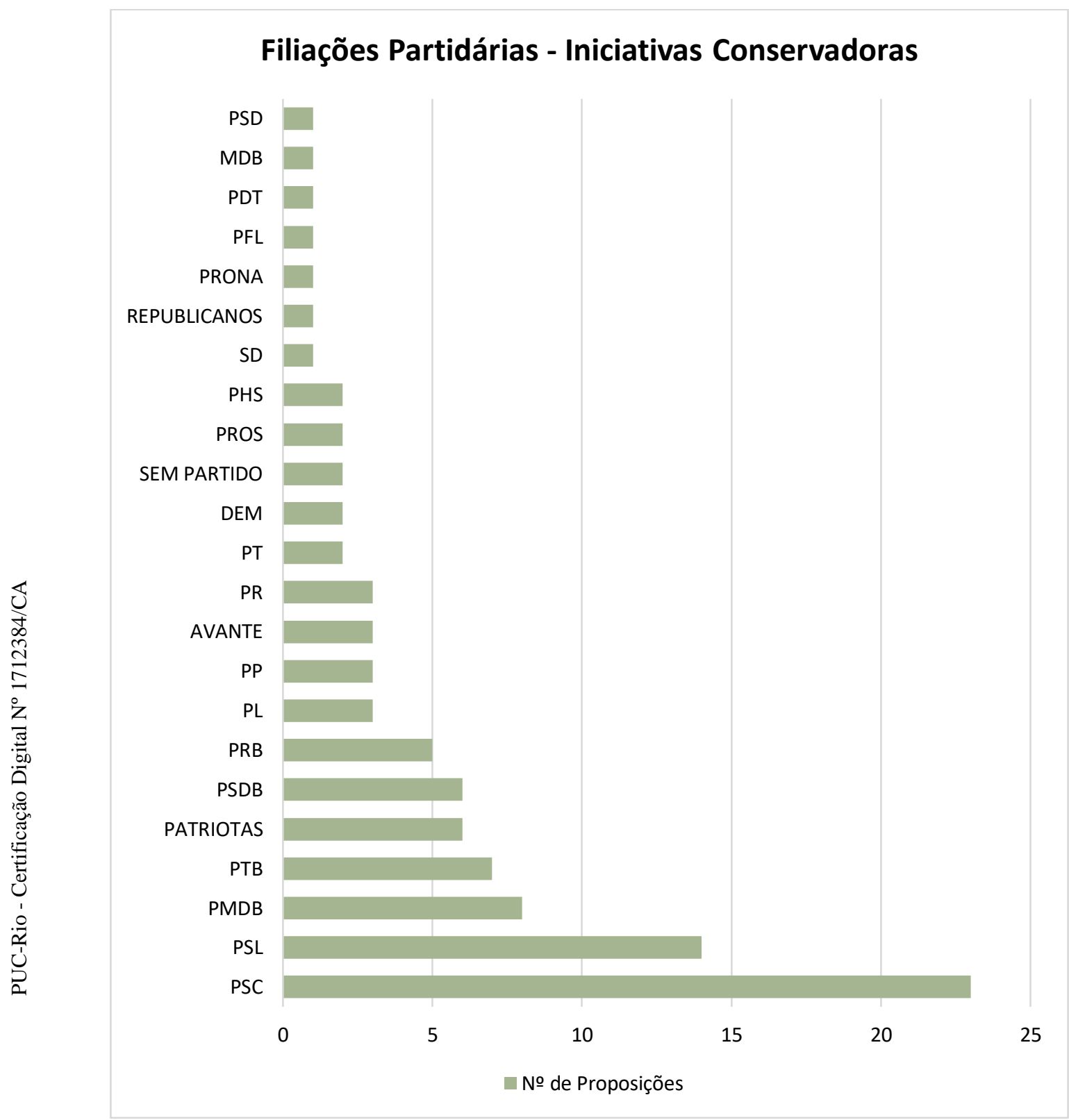

Figura 23: Frequência dos partidos que apresentaram proposições conservadoras, de acordo com o primeiro autor de cada proposição. FONTE: AUTORA (2021).

No que se refere aos autores propriamente ditos, destaco os quatro mais ativos: Professor Victório Galli (PMDB/MT 2007-2015, PSC/MT 2015-2017, PSL/MT 2018-) - 7 iniciativas, Pastor Marco Feliciano (PSC/SP 2011-2019, 
PODEMOS/SP 2018-2019, REPUBLICANOS/SP 2019-) - 6 iniciativas, Pastor Eurico (PSB/PE 2010-2016, PHS/PE 2016-2018, PATRIOTAS/PE 2018-) - 6 iniciativas, e, por fim, Hidekazu Takayama (PTB/PR 2003-2007, PMDB/PR 20072011, PSC/PR 2011-). Todos os deputados citados são pastores evangélicos e atuaram em diferentes frentes (Quadro 9).

\begin{tabular}{|c|c|c|c|}
\hline & $\begin{array}{l}\text { Denominação } \\
\text { Religiosa }\end{array}$ & $\begin{array}{c}\text { Atuação } \\
\text { Parlamentar }\end{array}$ & Iniciativas \\
\hline $\begin{array}{c}\text { Professor Victório Galli } \\
\text { (PMDB/MT; PSC/MT; PSL/MT) }\end{array}$ & Assembléia de Deus & $\begin{array}{l}\text { Lobby Religioso na } \\
\text { Educação e na } \\
\text { Sociedade } \\
\text { Combate à Ideologia } \\
\text { de Gênero } \\
\text { Combate à } \\
\text { Doutrinação Escolar }\end{array}$ & $\begin{array}{c}\text { PLs } \\
5686 / 16 ; \\
5774 / 06 ; \\
5487 / 10 ; \\
4293 / 12 ; \\
8229 / 17 \\
\text { PDCs } \\
48 / 15 ; 213 / 15\end{array}$ \\
\hline $\begin{array}{c}\text { Pr Marco Feliciano } \\
\text { (PSC/SP; PODEMOS/SP; } \\
\text { REPUBLICANOS/SP) }\end{array}$ & $\begin{array}{c}\text { Catedral do } \\
\text { Avivamento (ligada à } \\
\text { Assembléia de Deus) }\end{array}$ & $\begin{array}{l}\text { Lobby Religioso na } \\
\text { Educação e na } \\
\text { Sociedade } \\
\text { Combate à Ideologia } \\
\text { de Gênero }\end{array}$ & $\begin{array}{c}\text { PLs } \\
1021 / 11 ; \\
309 / 11 \\
8099 / 14 \\
3235 / 15 \\
3236 / 15 \\
\text { PDC } \\
16 / 15 \\
\end{array}$ \\
\hline $\begin{array}{c}\text { Pr Eurico } \\
\text { (PSB/PE; PHS/PE; } \\
\text { PATRIOTAS/PE) }\end{array}$ & Assembléia de Deus & $\begin{array}{l}\text { Lobby Religioso na } \\
\text { Educação e na } \\
\text { Sociedade } \\
\text { Combate à Ideologia } \\
\text { de Gênero } \\
\text { Combate à } \\
\text { Doutrinação Escolar } \\
\text { Lobby Pró Ensino } \\
\text { Domiciliar }\end{array}$ & $\begin{array}{c}\text { PLs } \\
8933 / 17 \\
5852 / 19 \\
5886 / 19 \\
258 / 19 ; \\
5490 / 19 ; \\
\text { PDC } \\
214 / 15\end{array}$ \\
\hline $\begin{array}{c}\text { Hedekazu Takayama } \\
\text { (PTB/PR; PMDB/PR; PSC/PR) }\end{array}$ & Assembléia de Deus & $\begin{array}{l}\text { Lobby Religioso na } \\
\text { Educação e na } \\
\text { Sociedade } \\
\text { Combate à Ideologia } \\
\text { de Gênero }\end{array}$ & $\begin{array}{c}\text { PLs } \\
1256 / 03 ; \\
6314 / 05 ; \\
3044 / 15 ; \\
2873 / 15\end{array}$ \\
\hline
\end{tabular}

Envolvidos em polêmicas de cunho religioso e discursos que associam a homossexualidade a práticas criminais, pecaminosas e imorais, defensores da liberdade de expressão, da "cura gay" e da família tradicional como base da sociedade, esses deputados sintetizam a atuação neoconservadora moralmente reguladora em curso na política brasileira (GAMA, 2019). Embora tenha se acentuado nos últimos anos, a tendência ao ativismo familista, regulador dos corpos 
e afetos, laico apenas quando convêm, não foi uma criação do Bolsonarismo. Conforme aponta Lacerda (2019), o neoconservadorismo da era Reagan já fazia uso dessas armas e via na educação um espaço potente para difusão de seus valores morais. A promoção do homeschooling, do criacionismo, do ensino da Bíblia na escola, da proibição das aulas sobre sexualidade para além de perspectivas informativas de saúde e proibitivas e a elevação da autoridade familiar acima dos interesses e funções da escola foram mobilizados nos EUA dos anos 1970 e 1980 e o são no Brasil de hoje.

Em busca de perspectivas plurais para educação e para a sociedade em geral, proposições progressistas foram identificadas e discutidas nessa seção. Sobre a filiação partidária dos proponentes (Figura 24), é possível identificar o protagonismo petista e psolista. Os três partidos com maior número de iniciativas consideradas progressistas são o PT, o PSOL e o PDT. Ligado historicamente à defesa de causas sociais e direitos de grupos marginalizados, o PT é o primeiro com mais de 20 iniciativas, seguido do PSOL - Partido Socialismo e Liberdade ( 9 proposições), fundado por quadros de esquerda saídos do PT. Na terceira posição está o PDT - Partido Democrático Trabalhista, atuante em questões voltadas à educação, com 7 iniciativas. 


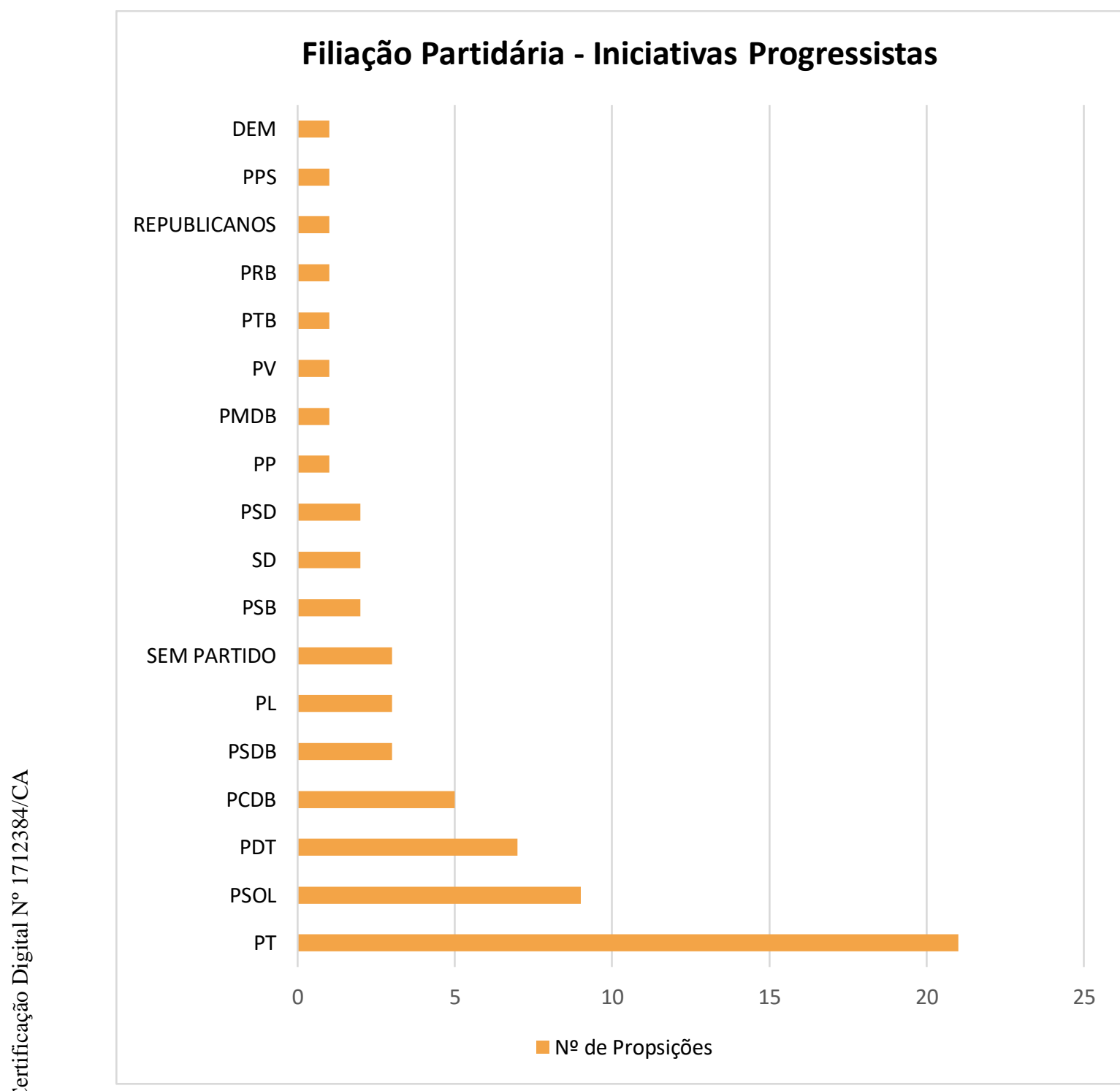

Figura 24: Frequência dos partidos que apresentaram proposições progressistas, de acordo com o primeiro autor de cada proposição. FONTE: AUTORA.

Destaco Jean Wyllys, ex-Deputado Federal pelo PSOL/RJ, e Érica Kokay, Deputada pelo PT/DF, como os proponentes com maior número de iniciativas de sua autoria, 4 e 2, respectivamente. Ambos buscaram defender perspectivas de valorização das diferenças e respeito aos direitos humanos em seus textos (Quadro 10). Vale destacar que Jean Wyllys renunciou ao seu mandato de deputado e saiu do Brasil após anos recebendo ameaças a sua vida e à segurança de seus familiares por parte de grupos conservadores ${ }^{56}$.

\footnotetext{
${ }^{56}$ Jean Willys abre mão de seu mandato: Disponível em: https://www1.folha.uol.com.br/poder/2019/01/com-medo-de-ameacas-jean-willys-do-psol-desistede-mandato-e-deixa-o-brasil.shtml. Acesso em 15/05/2021.
} 


\begin{tabular}{cccc}
\hline & $\begin{array}{c}\text { Ocupação } \\
\text { Profissional }\end{array}$ & Atuação Parlamentar & Iniciativas \\
\hline Jean & Jornalista e & $\begin{array}{c}\text { Defesa da Laicidade do Estado } \\
\text { Defesa de uma Educação }\end{array}$ & PLs \\
Wyllys & Professor & Pluralista e Democrática & Combate ao Preconceito e \\
& & Discriminação de Gênero/LGBT & 6005/2016; 9208/2017 \\
\hline Érica & Psicóloga (ex & Defesa da Laicidade do Estado & \\
Kokay & bancária & Defesa de uma Educação & PLs \\
& sindicalista & Pluralista e Democrática & 2805/2015; 4371/2016 \\
& & Combate ao Preconceito e & \\
\hline \multicolumn{2}{c}{ Quadro 10: Perfil de proponentes de iniciativas progressistas. FONTE: AUTORA (2021). }
\end{tabular}

Sobre a filiação partidária das propostas de lei consideradas ambíguas (Figura 25). Apesar dos números baixos é possível identificar o protagonismo do PSL (4 iniciativas), seguido do PT (3 iniciativas) e do PSB - Partido Socialista Brasileiro (3 iniciativas). A frequência aproximada de proposições realizadas por partidos políticos que ocupam posições diferentes, e, mesmo distante, do campo político pode indicar a própria movimentação da categoria no espectro de posicionamento analisado.

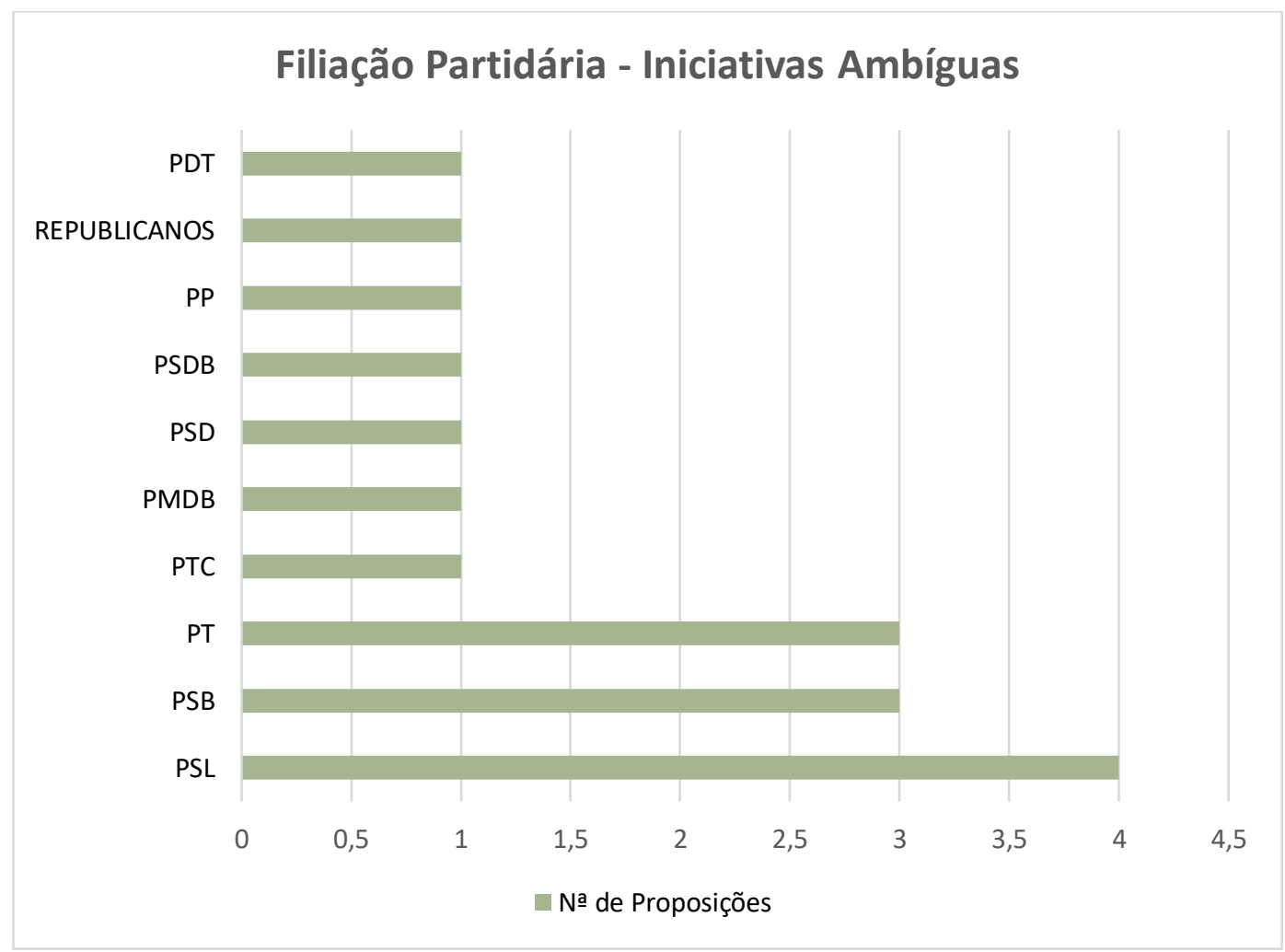

Figura 25: Lista de partidos aos quais autores proponentes de iniciativas ambíguas são filiados. FONTE: AUTORA (2021). 
Destaco o Deputado Átila Alexandre Nunes (PSL-RJ) - 2 iniciativas - como protagonista dessa categoria. É possível inferir que o combate à discriminação religiosa de qualquer tipo, bem como a defesa do livre exercício de crença, originase da própria experiência religiosa e familiar do propositor ${ }^{57}$. Ao professar um credo religioso minoritário e frequentemente demonizado por grupos cristãos, evangélicos e católicos, o parlamentar que é umbandista figura como um ator interessante no cenário conservador: tolerante nas questões religiosas, conservador quanto às pautas morais na escola. Pelo menos é o que sinaliza seu apoio ao PL $867 / 2014^{58}$, apresentado à Câmara Municipal do Rio de Janeiro por Carlos Bolsonaro.

O documento, ainda em tramitação, busca instituir no âmbito municipal dos sistemas de ensino o Programa Escola sem Partido. Embora o documento supracitado não integre o escopo desta investigação, a leitura de sua ementa permite a identificação da retórica conservadora aplicada à educação: a defesa da autoridade familiar sobre a formação escolar de seus filhos, formação em valores morais religiosos e o combate a doutrinação político-ideológica por partes dos professores das diferentes disciplinas. Tais elementos também integram os documentos identificados como conservadores ao longo da corrente análise.

$\mathrm{O}$ argumento desta tese é de que há uma agenda moralmente reguladora, securitária e socialmente antagônica em ação no Brasil atualmente e sua expressão pode ser analisada a partir do mapeamento da atuação política institucionalizada articulada a segmentos e interesses sociais outros, como religiosos, civis e militares (ALMEIDA, 2017). Até o presente momento esta investigação argumentou também que a dinâmica reativa que levou a proposições conservadoras durante os governos petistas de centro esquerda permitiu a construção de uma nova hegemonia política de orientação conservadora com a chegada de Jair Bolsonaro à Presidência da República - que apesar de não propor nenhum projeto dentro dessas temáticas, aderiu àqueles de temática aglutinadora como os que visam implementar a Escola

\footnotetext{
57 Átila Alexandre Nunes é neto do principal difusor da Umbanda no Brasil - o político e radialista Átila Nunes Pereira. Disponível em: https://extra.globo.com/noticias/religiao-e-fe/pai-paulo-deoxala/sacerdotes-de-umbanda-candomble-sao-homenageados-na-camara-municipal-do-rj23991857.html Acesso em: 13/11/2020. \begin{tabular}{llllll}
\hline 58 & Projeto & Lei & 867/2014.
\end{tabular} https://mail.camara.rj.gov.br/APL/Legislativos/scpro1316.nsf/f6d54a9bf09ac233032579de006bfef 6/5573ae961660b4cd83257ceb006bc7d4?OpenDocument Acesso: 18/11/2020.
} 
sem Partido e sustar a "ideologia de gênero" dos currículos nacionais (LACERDA, 2019).

Ao olhar para o papel ocupado pela educação nesse cenário de ativismo conservador em ascensão foi possível identificar tendências, sujeitos e abordagens tanto de natureza conservadora ou progressista, como aquelas de redação ambíguas ou pretensamente neutras. Tais discussões evidenciaram que há em jogo em última instância uma disputa pelo projeto de sociedade e democracia que experenciamos. Tal disputa se divide em linhas de frente que perpassam conceitos e defesas do que é e para que serve a família, a sexualidade, a laicidade, a educação pública. É a esse tipo de discussão que passo a seguir. Para tanto trago para o debate outros documentos e materiais, contudo, voltarei a particularidades encontradas nesse mapeamento da atuação parlamentar apresentado, referenciando sempre as unidades de registro (tema) e contexto (lugar em que a temática se insere), tal como indica Bardin (2016). 


\subsection{Ativismo moralmente regulador e socialmente intolerante: a influência religiosa sobre a educação}

Embora este trabalho não seja uma pesquisa da área de políticas públicas, busco olhar para o avanço do neoconservadorismo sobre a educação brasileira a partir de proposições legislativas, políticas públicas e outros documentos. Composto por interesses distintos que se articulam sob um guarda-chuva maior, o movimento neoconservador brasileiro apresenta uma agenda política clara: a adoção da racionalidade econômica e de livre mercado associado ao moralismo regulador fortemente religioso (principalmente cristãs) e às demandas punitivistas e securitárias (ALMEIDA, 2017; LACERDA, 2019). Assim, se o Brasil vivencia um período turbulento marcado por avanços conservadores em todos os segmentos sociais, a educação não foge a essa realidade (SEPÚLVEDA; SEPÚVELDA, 2016).

A modernização conservadora da educação, tal como discute Apple (2002), acompanha a virada à direita dos rumos políticos em diferentes países ao longo das últimas décadas, chamada pelo autor de restauração conservadora. Assim como o movimento que lhe deu origem, conjuga orientações e interesses múltiplos: econômicos, ideológicos, morais, religiosos e meritocráticos, entre outros. Conforme exposto no levantamento anteriormente apresentado, o ativismo moral/religioso é aquele que mais se destaca no projeto de modernização conservadora educacional brasileiro. É à discussão dele que se dedica essa seção. Para tanto chamo à discussão dois tipos de documentos: os trechos e contextos de políticas voltadas para à educação anteriores ao Bolsonarismo (PNE e BNCC) e a análise dos outros materiais mais próximos de Jair Bolsonaro (o Manifesto à Nação, produzido pela Frente Parlamentar Evangélica durante às eleições de 2018, os discursos de posse realizados pelo atual presidente na Câmara dos Deputados e no Planalto em 2019 e o PECIM, programa que institui as escolas cívico militares).

Os embates em torno de temas como diversidade/orientação sexual e influência religiosa no espaço público integram aquilo que Ronaldo Almeida (2017; 2019) chama de linha de força conservadora moralmente reguladora. Linha de força que, segundo o autor, vem ganhando destaque no Poder Legislativo a despeito do 
recente período de avanços nas conquistas de direitos sociais, civis, reprodutivos e sexuais vivido - não sem disputas e negociações - em nossa jovem democracia. A entrada dos evangélicos na política institucional a partir dos anos 80 deve ser vista como um divisor de águas para entender esse fenômeno, pois se nas primeiras décadas de atuação institucionalizada estes agentes buscavam mais a canalização de recursos para suas redes religiosas (concessões de meios de comunicação e isenção de impostos) do que ações regulatórias sobre corpos, comportamentos e vínculos familiares, a situação se inverte atualmente (ALMEIDA, 2017).

\subsubsection{O silenciamento da diversidade: os casos PNE e BNCC}

Embora o Governo Bolsonaro seja apontado por muitos como o auge do conservadorismo político na história recente do Brasil, é preciso reafirmar que as investidas à direita e/ou reacionárias sobre à educação nacional antecedem sua chegada à presidência. A dinâmica reativa apontada no levantamento de proposições parlamentares indica o histórico de lutas, rupturas e alianças que pavimentaram o caminho para a situação hoje experimentada. As pressões realizadas sobre projetos como "Escola sem Homofobia" jocosamente apelidado de "Kit Gay" (2011), a retirada dos termos "gênero" e "sexualidade" do PNE (2014) e o ativismo "anti-doutrinação" exercido sobre a BNCC (2015-2017), bem como toda movimentação em torno do Movimento Escola sem Partido (MESP), e do combate à "Ideologia de Gênero" e à "influência de Paulo Freire" tanto no Congresso Nacional como em redes sociais e grupos civis organizados evidenciam essa realidade. Tais agendas trazem forte marca moralista, reforçam concepções tradicionais e reacionárias de educação, trabalho docente e família, e mostram-se totalmente alinhadas à linha de força moral discutida por Almeida (2017).

As debates aprovação do PNE e sua relação com a atuação conservadora gira em torno das disputas sobre a moralidade pública. Antes de tratar do assunto diretamente momento acredito ser preciso lançar alguma luz sobre os atravessamentos ideológicos relacionados ao Plano Nacional de Educação instituído pela Lei 13.005/2014. Previsto na Constituição Federal e aprovado após um longa demora, o documento apresenta um conjunto de metas a serem cumpridas até 2024 relacionadas à melhoria da qualidade dos segmentos fundamental e médio de ensino, acesso à educação infantil, aspectos sobre formação docente, 
investimentos econômicos, entre outros. No entanto foram os embates acerca das perspectivas de diversidade inclusas no texto votado pelos Deputados Federais que geraram adiamentos e debates.

$\mathrm{O}$ artigo 2, inciso 3, do PNE, trazia como diretriz a "superação das desigualdades educacionais, com ênfase na promoção da igualdade racial, regional, de gênero e de orientação sexual". Mobilizada e ruidosa, a Bancada Cristã/Evangélica fechou questão contra os termos que, segundo seus deputados, incentivaria a inversão de valores e deturparia os conceitos biológicos de homem e mulher. Cabe destacar que foi nos debates sobre o PNE que a expressão "Ideologia de Gênero", cunhado pelo Vaticano entre os anos 1990 e 2000, ganha destaque no Brasil. Diante do crescimento dos estudos de gênero, entendido como os papéis associados a homens e mulheres na sociedade, a partir da década 1970, e o avanço de movimentos feministas e LGBT obtidos nos anos subsequentes, a cúpula da Igreja Católica, a partir dos anos 1990, promoveu uma série de conferências e documentos que visava o combate àquilo que passaram a chamar de "ideologia de gênero" (MIGUEL, 2016). As discussões em torno de gênero como uma construção social passaram a ser denunciadas pelo Vaticano como algo contra a vontade divina, antinatural e antifamília. Nesse sentido, estabeleceu-se em diferentes países uma dinâmica reativa a leis e políticas públicas que representaram ganhos para mulheres e LGBTs. No Brasil, tal movimento se articulou rapidamente entre setores evangélicos pentecostais, parlamentares no congresso nacional e órgãos legislativos estaduais e municipais.

Somada à acusação de que o PT pretendia implementar uma "ditadura gay" através do "kit gay", a pressão sobre a supressão dos termos "gênero" e "sexualidade" surtiu efeito. Na redação final do documento, aprovado por Dilma Rousseff, consta a "erradicação de todas as formas de discriminação". Em uma reação em cadeia, abordagens sobre gênero e sexualidade também foram apagadas de planos estaduais e municipais de educação em todo país (LACERDA, 2019). O apagamento das questões sobre diversidade do PNE, capitaneada por Deputados como o Pastor Marcos Feliciano (PSC/SP) e o Pastor Eurico (PSB/PE), ambos identificados como principais propositores de iniciativas conservadoras, sinalizou uma vitória do lobby conservador sobre aquilo que eles entendem como tentativas de erosão da base da sociedade, a família. Essa pressão se fez sentir sobre a BNCC anos mais tarde. 
Integrantes do Movimento Escola sem Partido tensionaram ainda mais o já esgarçado processo de implementação da Base. A BNCC prevista pelo PNE também passou por disputas e silenciamentos até sua entrega à sociedade, em dezembro de 2017. As primeiras versões da Base foram gestadas no Governo Dilma e contou com a participação de diferentes segmentos sociais e educacionais em diferentes estágios de sua elaboração. Após o afastamento de Dilma e tomada de poder por Michel Temer, em 2016, grupos reacionários como o MESP inseriram a Base em sua agenda de patrulhamento (SEPULVEDA; SEPULVEDA, 2019). Cientes de sua capacidade de pressão e tensionamento, grupos neoconservadores passaram a exigir tanto que (i) a Base saísse das "garras" do Conselho Nacional de Educação (CNE) e do MEC, e passasse aos cuidados do Congresso Nacional, como (ii) questionaram as intenções e ideologias por trás dos conteúdos definidos pela documentos como obrigatórios, quanto o espaço de acolhimento de outros conteúdos compreendidos pela parte diversificada do currículo (MACEDO, 2017).

É importante destacar que os projetos de lei sobre Escola sem Partido apresentados no levantamento de iniciativas parlamentares dentro do bloco "Doutrinação" têm sua gênese no Movimento Escola sem Partido (MESP), criado em 2004, pelo advogado Miguel Nagib. Este, católico, afirma que sua motivação para fundar o movimento partiu de um relato de sua filha de que seu professor de história havia comparado Che Guevara a São Francisco de Assis em uma de suas aulas. Assim, o movimento tem como sua primeira bandeira combater a “doutrinação marxista” e "comunista” nas escolas. No entanto, é na década de 2010 que o movimento ganha força e visibilidade. Como aponta Miguel (2016), isso ocorre a partir do momento em que o MESP agrega o combate à chamada "ideologia de gênero" a sua pauta.

A ofensiva contra os debates sobre gênero e diversidade sexual da escola se articula à pauta do MESP, reforçando uma visão que defende a primazia da família sobre a escola na decisão do que deve ser ensinado. Dessa maneira, projetos de lei de Escola sem Partido que, a partir de 2014, se multiplicaram por diferentes cidades, estados e no congresso nacional, destacam, textualmente, que a escola só deverá ensinar os valores com os quais a família esteja de acordo, sobretudo no que diz respeito à sexualidade e crenças religiosas. Assim, o papel atribuído à escola é apenas o de instruir os alunos em determinados conteúdos, enquanto a família é responsável pela transmissão de valores (PENNA, 2017). O grupo em questão 
defendeu ativamente a cooptação do processo de elaboração da Base por parte do Congresso Nacional notadamente conservador.

Vale destacar, no entanto, que lobby empresarial envolvido no processo de gestação da Base desde o seu início se posicionou de maneira contrária à atuação do MESP, situação que corrobora a ideia de o neoconservadorismo funcionar como um guarda-chuva de interesses e agentes que se aproximam e se afastam de acordo com seus objetivos (ALMEIDA, 2017). Enquanto a Base poderia ser vista como um instrumento potente de difusão de valores morais e religiosos no currículo educacional por agentes conservadores ligados às pautas reacionárias ideológicas, para os agentes ligados às pautas econômicas na educação, essa polemização e tensionamento não interessava ao Movimento pela Base - capitaneado pela Fundação Lemann, e que conta com participação de membros que atuam em outras instituições, como Todos pela Educação, Instituto Ayrton Senna e Instituto Natura - e que batalhou ativamente pela aprovação do documento. Retornarei a essa questão na próxima seção.

Outro ponto importante de ser discutido se refere às mudanças ocorridas no texto e no processo de elaboração da Base após a deposição de Dilma Rousseff. A terceira versão apresentada pela BNCC diferia das duas versões anteriores tanto na utilização de conceitos, quanto na abertura à consulta popular. $\mathrm{O}$ documento entregue por Michel Temer não conta com os direitos inerentes à educação trazidos pelas versões antecessoras, mas sim listas de habilidades e competências a serem desenvolvidas nos diferentes níveis de ensino e disciplina. Tal mudanças foram feitas de maneira vertical, sem desconsiderando todo o processo de discussão do documento com a comunidade escolar de todo país realizado até então.

A terceira versão encaminhada ao CNE pelo MEC trazia também as discussões sobre as diferentes concepções de "corpo, gênero e sexualidade" segundo diferentes tradições religiosas e filosofias de vida, ou seja, um eixo dentro do Ensino Religioso (ER), não sendo trado em nenhuma outra disciplina ou eixo temático. $\mathrm{O}$ órgão retirou do documento esta abordagem, mas manteve o veto conferido ao tratamento da diversidade sexual no restante da Base ${ }^{59}$. É importante

59 CNE retira discussões sobre gênero e sexualidade do ensino religioso definido pela Base. Disponível em: https://oglobo.globo.com/sociedade/educacao/cne-retira-genero-orientacao-sexualda-base-curricular-22179063. Acesso em 15/04/2021. 
destacar que a inserção do Ensino Religioso como componente curricular da área de Ciências Humanas na BNCC ocorrida na primeira versão foi apontada como uma aberração epistemológica e pedagógica em dois sentidos: i. ao partir de uma premissa falsa de pertencimento do ER aos conteúdos curriculares das Ciências Sociais (Humanas), o documento ignoraria o princípio do agnosticismo metodológico que estrutura a área (a recusa em confirmar ou refutar conteúdos sobrenaturais não passíveis de análise empírica) e ii. estipular os conteúdos a serem abordados em cada ano dos níveis infantil e fundamental do ensino reforça a obrigatoriedade de curso do ER no chão da escola a despeito de seu caráter constitucional facultativo, uma vez que apenas a oferta é definida como obrigatória (CUNHA, 2016).

Cabe destacar que na versão final da Base ele passa constituir uma área de conhecimento própria que deve obedecer a quatro objetivos principais:

a) Proporcionar a aprendizagem dos conhecimentos religiosos, culturais e estéticos, a partir das manifestações religiosas percebidas na realidade dos educandos; b) Propiciar conhecimentos sobre o direito à liberdade de consciência e de crença, no constante propósito de promoção dos direitos humanos; c) Desenvolver competências e habilidades que contribuam para o diálogo entre perspectivas religiosas e seculares de vida, exercitando o respeito à liberdade de concepções e o pluralismo de ideias, de acordo com a Constituição Federal; d) Contribuir para que os educandos construam seus sentidos pessoais de vida a partir de valores, princípios éticos e da cidadania.

É interessante observar que aos mesmo tempo em que integra uma retórica de promotor de uma "cultura de paz" e diálogo respeitoso entre perspectivas religiosas e seculares de vida em sociedade, o ER se pretende capaz de contribuir para à formação de valores e princípios ético-cidadãos dos alunos de todo o Brasil. Uma educação que se pretenda emancipatória e plural, capaz de capacitar seus alunos ao diálogo, deve ser dever de todas as disciplinas. Para Cunha (2016, p.17), não faz sentido apresentar o

o professor de ER como especialista em tolerância, virtude que os ramos do tronco abraâmico (judaico, cristão e muçulmano) carecem nas respectivas folhas de serviços prestados à paz. Não se trata apenas de tolerar o diferente. A tarefa da educação laica é lutar contra a discriminação material e simbólica nas dimensões em que ela aparece em cada estabelecimento de ensino: racial, de gênero e religiosa. Mais do que sujeito, a religião é objeto da luta contra as discriminações, na escola e fora dela. 
No que se refere ao corpo humano e as questões relacionadas à sexualidade, na versão final homologada, estes assuntos são tratados de maneira geral a partir das perspectivas da saúde e do autocuidado nos anos iniciais e finais do Ensino Fundamental na disciplina de Ciências.

Nos anos iniciais, pretende-se que, em continuidade às abordagens na Educação Infantil, as crianças ampliem os seus conhecimentos e apreço pelo seu corpo, identifiquem os cuidados necessários para a manutenção da saúde e integridade do organismo e desenvolvam atitudes de respeito e acolhimento pelas diferenças individuais, tanto no que diz respeito à diversidade étnico-cultural quanto em relação à inclusão de alunos da educação especial. Nos anos finais, são abordados também temas relacionados à reprodução e à sexualidade humana, assuntos de grande interesse e relevância social nessa faixa etária, assim como são relevantes, também, o conhecimento das condições de saúde, do saneamento básico, da qualidade do ar e das condições nutricionais da população brasileira (BRASIL, 2017, pág. 329. Grifos meus).

\begin{abstract}
Além disso, à medida que se aproxima a conclusão do Ensino Fundamental, os alunos são capazes de estabelecer relações ainda mais profundas entre a ciência, a natureza, a tecnologia e a sociedade, o que significa lançar mão do conhecimento científico e tecnológico para compreender os fenômenos e conhecer o mundo, o ambiente, a dinâmica da natureza. Além disso, é fundamental que tenham condições de ser protagonistas na escolha de posicionamentos que valorizem as experiências pessoais e coletivas, e representem o autocuidado com seu corpo e o respeito com o do outro, na perspectiva do cuidado integral à saúde física, mental, sexual e reprodutiva (BRASIL, 2017, p. 345. Grifos meus).
\end{abstract}

No $8^{\circ}$ ano do Ensino Fundamental, dentro da unidade temática "vida e evolução" na disciplina de Ciências, encontra-se os objetos de conhecimento "mecanismos reprodutivos" e "sexualidade". Para a habilidade EF08CI11 indica: "Selecionar argumentos que evidenciem as múltiplas dimensões da sexualidade humana (biológica, sociocultural, afetiva e ética) (BRASIL, 2017, p.351)”. Embora se mostre mais profunda do que a ideia de autocuidado e conhecimento puramente biológico, o texto não traz indicações problematizações culturais, raciais e econômicas necessárias à plena construção de conhecimento sobre o tema. $\mathrm{O}$ silenciamento da diversidade sexual e seus componentes socioculturais, políticos e econômicos, a restrição da abordagem da sexualidade humana às perspectivas de 
autocuidado e saúde, ou ainda de maneira ampla e vaga especialmente tratados apenas no $8^{\circ}$ ano na disciplina de Ciências do Ensino Fundamental, somados à abrangente oferta do ER durante todos os anos desse segmento educacional permitem apontar a influência de grupos conservadores de origem religiosa no apagamento de alguns assunto e na promoção de outros (BORBA et al, 2019).

Esses achados se somam às retóricas tanto do Manifesto à Nação, produzido pela Frente Parlamentar Evangélica (2019), quanto nos discursos de posse proferidos por Jair Bolsonaro em seu primeiro dia como Presidente do Brasil e seu decreto sobre a criação de escolas cívico militares. Os dados encontrados a partir das análises desses documentos permitem um entendimento mais contextualizado da atuação neoconservadora sobre a educação brasileira. É a essa discussão que passo a seguir.

\subsubsection{Combate ideológico: os perigos da doutrinação e as demandas por ordem no universo educacional}

A articulação entre as perspectivas pró-família, pró-antagonismos sociais e pró-racionalidade econômica que orienta o neoconservadorismo educacional atua, segundo Michael Apple (2002), em duas frentes: i. a manipulação e alteração de sentidos e ii. o direcionamento cada mais à direita do senso comum. Ao utilizar demandas e insatisfações reais relacionadas a esse universo (como melhor capacitação dos docentes e profissionais da educação, ampliação do acesso aos diferentes segmentos e níveis educacionais, melhoria da qualidade e investimento, combate à violência escolar, entre tantas outras) como combustível para proposição de mudanças de cunho conservador. Tal processo perpassa necessariamente pela fabricação de inimigos e espalhamento de pânicos e desconfianças sobre o ensino público (a ideologia que perverte valores morais e comportamentos sexuais, o gasto errôneo/corrupto dos investimentos realizados, a atuação doutrinária dos professores).

A solução oferecida pelos agentes neoconservadores é simples, ainda segundo Apple (2002): um Estado menor nas questões econômicas (mercadorização educacional) e um Estado maior nas questões morais e securitárias (educação moralmente regulada e militarmente inspirada). Neste momento, interessa-me as duas últimas "soluções" e suas marcas encontradas nos 
documentos supracitados. O Manifesto à Nação (2019), disponibilizado durante a corrida presidencial em 2018, por exemplo, se apresenta como uma carta de intenções e uma agenda de atuação da Frente Parlamentar Evangélica sobre três eixos: eficiência econômica, segurança jurídica e revolução educacional. Segundo o documento, o Brasil vive uma época de atrasos econômicos, insegurança jurídica na manutenção de contratos e perversão dos valores educacionais. Para mudar essa situação, os autores propõem ações objetivas e às justificam a partir de argumentos econômicos neoliberais, valores morais e lógicas religiosas.

Alinhado fortemente e esse discurso em toda sua campanha, Jair Bolsonaro comprometeu-se diversas vezes com o combate à "ideologia de gênero" nas escolas e do "comunismo" na sociedade em geral. A pauta moral relacionada à educação defendida por Bolsonaro em sua campanha articula a defesa da família, da inocência das crianças, do ensino sem amarras ideológicas e o combate a toda sorte de perversões de valores morais e religiosos, e já foi mencionada nesse trabalho em diferentes momentos. O apelo dessa abordagem sempre foi forte entre seus apoiadores e não ficou de fora de seus discursos de posse. Vale destacar que ainda hoje, acuados pelo descontentamento popular e investigações relacionadas à gestão negligente da pandemia Covid-19, integrantes do governo ${ }^{60}$ e o próprio presidente lançam mão dessas discussões quando se referem à educação brasileira ${ }^{61}$. Em ambas as situações relatadas a influência de Paulo Freire foi identificada como algo nocivo, uma porta para a "doutrinação marxista", entendimento que integrava inclusive o plano de governo do então candidato (KOHAN, 2019).

A criação de escolas que utilizam o modelo militar de gestão educacional, promessa de campanha de Jair Bolsonaro ${ }^{62}$, serviria à melhoria da qualidade do ensino público através do envolvimento de militares em atividades administrativas da escola. A retórica em defesa desse modelo de administração escolar se escora na promoção de valores humanos, éticos e morais, da formação integral do cidadão e de aumento do sentimento de pertencimento e diminuição dos índices de violência

\footnotetext{
${ }^{60}$ Paulo Guedes afirma que na universidade pública há Paulo Freire, drogas e ensino de sexo para crianças. Disponível em: https://noticias.uol.com.br/colunas/reinaldo-azevedo/2021/04/28/guedesbaba-3-na-universidade-publica-ha-maconha-e-sexo-para-criancas.htm Acesso: 18/05/2021

${ }^{61}$ Jair Bolsonaro, acuado pela CPI da Covid-19, evoca Kit Gay e diz ter zerado sexualização infantil na escola. Disponível em: https://www.cartacapital.com.br/politica/acuado-pela-cpi-bolsonaroevoca-o-kit-gay-e-diz-que-zerou-a-sexualizacao-nas-escolas/. Acesso: 18/05/2021

62 Jair Bolsonaro quer um colégio militar em cada capital do Brasil. Disponível em: https://noticias.uol.com.br/confere/ultimas-noticias/eder-content/2018/09/20/eleicoes-bolsonaropromessa-educacao-colegio-militar-cada-capital-2020.htm. Acesso 18/05/2021
} 
em ambiente escolar (PERA, 2019). A ênfase em valores tradicionais, ordem, patriotismo e hierarquia, características presentes em propostas educacionais desse tipo, tal como discutido no levantamento de iniciativas parlamentares anteriormente, aproxima o eixo de atuação moralmente regulador e socialmente intolerante na educação de demandas por segurança existentes em contextos mais amplos do neoconservadorismo brasileiro (ALMEIDA, 2017; 2019).

Assim, a análise cruzada do Manifesto, dos discursos de posse e do PECIM, Programa Nacional de Escolas Cívico Militares permitiu a identificação de núcleos de sentido que integram a atuação conservadora e se somam ao apagamento das questões sobre diversidade e forte influência religiosa identificados na análise dos trechos e contextos do PNE e da BNCC. A codificação desses documentos, realizada de acordo os parâmetros estabelecidos na metodologia a deste trabalho, possibilitou a identificação da ocorrência e frequência de registros dos principais temas abordados (Quadro 11).

\begin{tabular}{|c|c|c|c|c|c|}
\hline $\begin{array}{c}\text { Unidade de Registro } \\
\text { (Tema) }\end{array}$ & Manifesto & PECIM & $\begin{array}{c}\text { Discurso } \\
\text { Posse Câmara }\end{array}$ & $\begin{array}{c}\text { Discurso } \\
\text { Posse } \\
\text { Planalto }\end{array}$ & Totais \\
\hline Diversidade & 4 & 0 & 1 & 0 & 5 \\
\hline $\begin{array}{c}\text { Educação } \\
\text { (Funções e Atribuições) }\end{array}$ & 33 & 9 & 3 & 4 & 49 \\
\hline Família & 4 & 0 & 1 & 2 & 6 \\
\hline Religião & 3 & 0 & 3 & 3 & 9 \\
\hline Segurança & 1 & 1 & 1 & 1 & 4 \\
\hline Valores & 14 & 2 & 2 & 4 & 22 \\
\hline $\begin{array}{l}\text { Perspectivas de Vida } \\
\text { em Sociedade }\end{array}$ & 8 & 1 & 6 & 7 & 22 \\
\hline Totais & 63 & 13 & 17 & 21 & 114 \\
\hline
\end{tabular}

A leitura das informações acima permite observar que o documento com mais temáticas de interesse encontradas em números absolutos foi o Manifesto à Nação. Na sequência encontram-se os discursos de posse presidencial e o PECIM. Cada um dos temas foi destacado levando em consideração sua relação com a educação, tal como realizado na revisão bibliográfica e na análise de iniciativas 
parlamentares apresentados anteriormente, em outras palavras: ou se referiam à educação de maneira central ou a utilizavam como um componente retórico argumentativo. Assim, a preocupação do Manifesto em abordar todos os temas se justifica pela natureza do documento: uma carta aberta à nação sobre os interesses de atuação de seus propositores. Essa também parece ser o caso dos discursos de posse que variam em maior ou menor grau o número de registros de acordo com o público. Por fim, o PECIM, decreto presidencial diretamente voltado para à área educacional, não apresenta a ocorrência de alguns registros temáticos, mas enfatiza outros, conforme discutirei a diante.

A leitura minuciosa dos destaques realizados articulados aos demais achados foram agrupados em categorias iniciais definidas à priori de acordo com o referencial utilizado, sendo elas: conceito e atuação da família, diversidade/sexualidade, perspectivas de vida em sociedade, funções e atribuições da educação e, por fim, influência religiosa sobre à educação. Após novas rodadas de análise e cruzamento dos dados, cheguei às categorias finais da análise: familismo, combate à diversidade e a privatização do espaço público. Cada uma delas compõe um braço do ativismo moralmente regulador e socialmente intolerante aqui discutido.

\subsubsection{Família, educação, diversidade e demandas por ordem: os braços do ativismo moralmente regulador e socialmente intolerante}

A primeira categoria a ser discutida é o familismo. A defesa da família, dos valores familiares e da autoridade familiar sobre o processo de escolarização foi identificada como um dos principais interesse da atuação neoconservadora relacionados à educação. Essas perspectivas aparecem em iniciativas parlamentares, por trás de pressões pelo silenciamento de discussões de gênero e sexualidade nos currículos educacionais, nos discursos presidenciais e na agenda de atuação concebida pela Frente Parlamentar Evangélica apresentada pelo Manifesto à Nação (Quadro 12). 


\begin{tabular}{|c|c|c|c|}
\hline $\begin{array}{c}\text { Unidades } \\
\text { de Registro }\end{array}$ & $\begin{array}{c}\text { Unidade de } \\
\text { Contexto }\end{array}$ & Categoria & Destaque \\
\hline $\begin{array}{c}\text { Funções da } \\
\text { Educação }\end{array}$ & $\begin{array}{c}\text { PL } \\
6484 / 2002 \\
\text { "Institui a } \\
\text { Educação } \\
\text { Domiciliar" } \\
\text { Osório } \\
\text { Adriano } \\
\text { (PFL/DF) }\end{array}$ & Familismo & $\begin{array}{l}\text { Difunde-se, portanto, a cada dia mais a ideia de que } \\
\text { o ensino domiciliar não interrompe o processo de } \\
\text { educação de crianças e adolescentes. Há problemas, } \\
\text { evidentemente, mas também virtudes como a } \\
\text { contribuição para evitar que crianças e adolescentes } \\
\text { sejam submetidos à violência das ruas, que já se } \\
\text { estende às escolas, a influências danosas ao seu } \\
\text { desenvolvimento e ao uso de drogas, já que os pais } \\
\text { podem protegê-los, acompanhando de perto esses } \\
\text { estudantes nas suas atividades (p.3. Grifos meus). }\end{array}$ \\
\hline \multirow[t]{2}{*}{$\begin{array}{c}\text { Funções da } \\
\text { Educação }\end{array}$} & $\begin{array}{l}\text { PL } \\
246 / 2019 \\
\text { "Institui o } \\
\text { Programa } \\
\text { Escola Sem } \\
\text { Partido" } \\
\text { Bia Kicis } \\
\text { (PSL/DF) }\end{array}$ & & $\begin{array}{l}\text { I - não se aproveitará da audiência cativa dos alunos } \\
\text { para promover os seus próprios interesses, opiniões, } \\
\text { concepções ou preferências ideológicas, religiosas, } \\
\text { morais, políticas e partidárias; II - não favorecerá } \\
\text { nem prejudicará ou constrangerá os alunos em razão } \\
\text { de suas convicções políticas, ideológicas, morais ou } \\
\text { religiosas, ou da falta delas; III - não fará } \\
\text { propaganda político-partidária em sala de aula nem } \\
\text { incitará seus alunos a participar de manifestações, } \\
\text { atos públicos e passeatas; IV - ao tratar de questões } \\
\text { políticas, socioculturais e econômicas, apresentará } \\
\text { aos alunos, de forma justa, as principais versões, } \\
\text { teorias, opiniões; V - respeitará o direito dos pais } \\
\text { dos alunos a que seus filhos recebam a educação } \\
\text { religiosa e moral que esteja de acordo com as suas } \\
\text { próprias convicç̃̃es; VI - não permitirá que os } \\
\text { direitos assegurados nos itens anteriores sejam } \\
\text { violados pela ação de estudantes ou de terceiros, } \\
\text { dentro da sala de aula. (Grifos meus) }\end{array}$ \\
\hline & $\begin{array}{c}\text { Manifesto à } \\
\text { Nação }\end{array}$ & Familismo & $\begin{array}{l}\text { De fato, para além da pauta tradicionalmente por } \\
\text { nós defendida, - de preservação dos valores } \\
\text { cristãos } \boldsymbol{e} \text { de defesa da família -, compreendemos } \\
\text { que é chegada a hora de darmos uma contribuição } \\
\text { maior à sociedade, a qual seja consentânea aos mais } \\
\text { de } 45 \text { milhões de eleitores brasileiros que professam } \\
\text { a fé evangélica (p.2. Grifos meus) } \\
\text { O ataque às crianças, adolescentes e suas famílias } \\
\text { têm por objetivo destruir os alicerces da } \\
\text { Civilização como condição prévia para a criação das } \\
\text { condições objetivas de instituir uma ditadura } \\
\text { totalitária, escravizando as consciências pela força } \\
\text { do Estado. A sociedade civil fica refém do Estado. } \\
\text { Com isso, introduziram nas escolas todo tipo de } \\
\text { pornografia, licenciosidade, perversão etc. (p.55 } \\
\text { Grifos meus) }\end{array}$ \\
\hline $\begin{array}{c}\text { Família/ } \\
\text { Valores/ } \\
\text { Diversidade }\end{array}$ & $\begin{array}{c}\text { Discurso de } \\
\text { Posse } \\
\text { (Câmara) }\end{array}$ & Familismo & $\begin{array}{l}\text { Vamos unir o povo, valorizar a família, respeitar as } \\
\text { religiões e nossa tradição judaico-cristã, combater a } \\
\text { ideologia de gênero, conservando nossos valores. O } \\
\text { Brasil voltará a ser um país livre de amarras } \\
\text { ideológicas. (Grifos meus) }\end{array}$ \\
\hline $\begin{array}{l}\text { Família/ } \\
\text { Valores }\end{array}$ & $\begin{array}{c}\text { Discurso de } \\
\text { Posse } \\
\text { (Planalto) }\end{array}$ & Familismo & $\begin{array}{l}\text { Temos o grande desafio de enfrentar os efeitos da } \\
\text { crise econômica, do desemprego recorde, da } \\
\text { ideologização de nossas crianças, do } \\
\text { desvirtuamento dos direitos humanos, e da } \\
\text { desconstrução da familia. (Grifos meus) }\end{array}$ \\
\hline
\end{tabular}


Diferentes temas foram encontrados em associação a perspectivas de defesa da família - doutrinação, sexualidade, defesa de valores morais e religiosos, algo que, em meu entendimento, reforça seu poder analítico da categoria. A pauta familiar surge ao mesmo tempo como um bem a ser defendido e um agente poderoso que deve influir sobre os rumos educacionais de seus filhos. Longe de ser uma categoria inédita, o familismo na educação reforça reflexões trazidas pela literatura. A defesa da família patriarcal surge no neoconservadorismo, segundo Marina Lacerda (2019), como uma resposta à "depravação moral” - que se espalhou pela sociedade e se percebe nos avanços obtidos por coletivos femininas e LGBT que se soma ao entendimento religiosos cristão de base nuclear da sociedade.

O desajuste familiar também é apontado como recurso retórico econômico já que a falta de uma figura paterna, ou a constante ausência materna do lar para trabalhar fora, levaria à delinquência, à gravidez na adolescência e à dependência das políticas de bem-estar social. O fortalecimento da família tradicional patriarcal seria o melhor programa contra a pobreza. A atuação familista na educação é vista então como uma resposta aos perigos do ambiente educacional. Além de compor a retórica neoconservadora em torno do combate à diversidade e à pluralidade sexual, o familismo atua em duas linhas de frente: a defesa da educação domiciliar e o combate à doutrinação docente. Ambas materializam para a pauta educacional a defesa dos valores e da autoridade familiar.

A possibilidade de não matricular os filhos em escolas públicas ou particulares, desde que garantissem sua formação em âmbito domiciliar, foi permitida às famílias pela legislação brasileira até a constituição de 1988. Com a redemocratização, ocorrida no final dos anos 1980, diferentes instrumentos, órgãos e instituições, tais como o Estatuto da Criança e Adolescente e o Supremo Tribunal Federal, passaram a entender e regulamentar a matrícula e a frequência à educação escolar como obrigatórias. Entretanto, em abril de 2019, o Ministério da Mulher, Família e Direitos Humanos, sob a liderança da ministra Damares Alves ${ }^{63}$, encaminhou ao Congresso projeto de lei (PL n. 2401/2019) para a legalização da prática de educação domiciliar, alegando que é direito natural dos pais decidir se a

63 Damares Alves é advogada e pastora evangélica. Esteve à frente da Igreja Evangélica Quadrangular e da Igreja Batista de Lagoinha, em Belo Horizonte. É conhecido por seu posicionamento "anti aborto", "pró-família" e "anti ideologia de gênero". Disponível: https://epoca.globo.com/guilherme-amado/governo-vai-propor-regulamentacao-dohomeschooling-24351388. Acesso em 09/09/2020 
educação dos filhos será realizada no âmbito da família ou em escolas públicas ou particulares (CURY, 2019). O documento segue em tramitação apensado a outros de natureza semelhante.

Se nos contextos mais gerais da sociedade a atuação neoconservadora reacionária apregoa os perigos do comunismo marxista, encarnado por pela Venezuela Bolivariana, como uma ameaça à democracia nacional (MIGUEL, 2016), nos PLs que advogam uma "Escola sem Partido" tramitando no Congresso Nacional e nos debates e discursos inflamados que tomam o país, sobretudo nas redes sociais, há um perigo real que habita as escolas e universidades brasileiras: a doutrinação docente. Segundo essa perspectiva, professores das diferentes disciplinas atuam de modo a incutir em seus alunos as próprias crenças e ideologias político-partidárias. Daí a necessidade de os pais tomarem as rédeas da educação moral, sexual e religiosa de seus filhos (MOURA, 2018).

Os embates envolvendo as questões de gênero e pluralidade de ideias e comportamentos mobilizam o familismo articulado a outra categoria elencada: o combate à diversidade. Dentro dessa categoria atuam linhas de força morais e socialmente intolerantes que mobilizam sentimentos como fobia, revanche e ódio (ALMEIDA, 2017). O medo da diferença norteia essa categoria. Teme-se à sexualidade diferente, o credo e, mesmo escamoteado, à cor diferente, em casos de racismo religioso, o livre debate de ideias diferentes. O silenciamento das discussões sobre gênero e sexualidade nos documentos norteadores da educação nacional, o tratamento do cristianismo como fonte de valores morais universais e conhecimentos superiores a outros oriundos de outras matrizes - como as religiões de matriz africana, ou mesmo a ciência - , tentativas políticas institucionalizadas de censura docente, procuram estabelecer uma realidade educacional homogeneizante, pouca afeita ao diálogo e ágil na antagonização de sujeitos e posicionamentos (Quadro 13). 


\begin{tabular}{|c|c|c|c|}
\hline $\begin{array}{l}\text { Unidade de } \\
\text { Registro }\end{array}$ & $\begin{array}{c}\text { Unidade de } \\
\text { Contexto }\end{array}$ & Categoria & Destaque \\
\hline Diversidade & $\begin{array}{c}\text { PL } \\
3235 / 2015\end{array}$ & $\begin{array}{c}\text { Combate à } \\
\text { Diversidade }\end{array}$ & $\begin{array}{l}\text { O que se pretende é insertar no Estatuto da } \\
\text { Criança e do Adolescente um dispositivo que } \\
\text { criminalize todo intento de disseminar, fomentar, } \\
\text { induzir ou incutir a deletéria ideologia de gênero } \\
\text { pela veiculação de termos e expressões como } \\
\text { "orientação sexual", "identidade de gênero", } \\
\text { "discriminação de gênero", "questões de gênero" } \\
\text { e seus sinônimos, em documentos e materiais } \\
\text { didático pedagógicos, bem como em atos } \\
\text { normativos oficiais, em diretrizes, planos e } \\
\text { programas governamentais. }\end{array}$ \\
\hline Diversidade & $\begin{array}{l}\text { Manifesto } \\
\text { à Nação }\end{array}$ & $\begin{array}{c}\text { Combate à } \\
\text { Diversidade }\end{array}$ & $\begin{array}{l}\text { Libertar a educação pública do autoritarismo da } \\
\text { ideologia de gênero, da ideologia da } \\
\text { pornografia, e devolver às famílias o direito da } \\
\text { educação sexual das suas crianças e } \\
\text { adolescentes. Defender o direito à inocência da } \\
\text { criança como direito humano universal. } \\
\text { A destruição dos valores morais e princípios do } \\
\text { mérito escolar e do mérito acadêmico } \\
\text { universitário contribuiu para a violência contra a } \\
\text { civilização judaico-cristã, atingindo duramente } \\
\text { o Cristianismo, tal como aconteceu na URSS e } \\
\text { demais Estados totalitários, como na Itália } \\
\text { Fascista e na Alemanha Nacional-Socialista, } \\
\text { China, Cuba etc. }\end{array}$ \\
\hline $\begin{array}{l}\text { Diversidade } \\
\text { / Laicidade }\end{array}$ & $\begin{array}{c}\text { Discurso de } \\
\text { Posse } \\
\text { (Câmara) }\end{array}$ & $\begin{array}{c}\text { Combate à } \\
\text { Diversidade }\end{array}$ & $\begin{array}{l}\text { Vamos unir o povo, valorizar a família, respeitar } \\
\text { as religiões e nossa tradição judaico-cristã, } \\
\text { combater a ideologia de gênero, conservando } \\
\text { nossos valores. O Brasil voltará a ser um país } \\
\text { livre de amarras ideológicas. }\end{array}$ \\
\hline $\begin{array}{c}\text { Funções da } \\
\text { Educação }\end{array}$ & $\begin{array}{c}\text { Discurso de } \\
\text { Posse } \\
\text { (Planalto) }\end{array}$ & $\begin{array}{c}\text { Combate à } \\
\text { Diversidade }\end{array}$ & $\begin{array}{l}\text { Daqui em diante, nos pautaremos pela vontade } \\
\text { soberana daqueles brasileiros: que querem boas } \\
\text { escolas, capazes de preparar seus filhos para o } \\
\text { mercado de trabalho e não para a militância } \\
\text { política. }\end{array}$ \\
\hline $\begin{array}{c}\text { Funções da } \\
\text { Educação }\end{array}$ & PECIM & $\begin{array}{c}\text { Combate à } \\
\text { Diversidade }\end{array}$ & $\begin{array}{l}\text { A gestão na área educacional será alcançada por } \\
\text { meio de ações destinadas ao desenvolvimento de } \\
\text { comportamentos, valores e atitudes, com vistas } \\
\text { ao desenvolvimento pleno do aluno e ao seu } \\
\text { preparo para o exercício da cidadania. } \\
\text { [Objetiva] propor e desenvolver um modelo de } \\
\text { escola de alto nível, com base nos padrões de } \\
\text { ensino e modelos pedagógicos empregados nos } \\
\text { colégios militares do Exército, das Polícias } \\
\text { Militares e dos Corpos de Bombeiros Militares, } \\
\text { para os ensinos fundamental e médio; }\end{array}$ \\
\hline
\end{tabular}

Quadro 10: Destaques relacionados à categoria Combate à Diversidade. FONTE: AUTORA (2021).

A investida socialmente intolerante que visa combater a diversidade no campo educacional se faz sentir em questões que extrapolam as discussões sobre gênero e sexualidade, muito embora esse seja um dos alvos preferenciais de 
movimentos reacionários neoconservadores. No entanto, é possível encontrar marcas dessa dimensão na desqualificação do trabalho docente e das escolas, consequência de uma perspectiva de constante vigilância e de perseguição a professoras e professores que são vistos como doutrinadores e por isso precisam ser guiados e vigiados por estatutos e leis ou inseridos numa estrutura cívico militar.

Sobre o PECIM e a questão do combate à diversidade é necessário destacar que o modelo educacional de alto nível baseado em valores não especificados no corpo do texto que visa o desenvolvimento de comportamentos e disposições necessárias ao pleno exercício da cidadania abre espaço para inferência. As demandas conservadoras ligadas à militarização no contexto social em geral possuem forte adesão popular e demandas punitivistas. Nela se inserem demandas por punição mais duras e longas, pena capital e diminuição da maioridade penal. Ronaldo Almeida (2017) destaca que apesar da atuação parlamentar evangélica nessa linha de força não ser tão expressiva quanto naquela relativa à moralidade, ela tem servido de linha auxiliar de aparelhos de segurança pública e privada (como corporações militares e empresas) a despeitos dos preceitos de amor ao próximos trazidas pelo Cristianismo.

O apoio da bancada evangélica aos projetos de lei securitários na Câmara sintetiza a atuação neoconservadora: "Os mecanismos de agregação social são a religião e a família; o desvio deve levar à punição rigorosa" (LACERDA, 2019, p.143). É nesse contexto que se insere as demandas por militarização escolar. O Projeto de lei 4887/2019 de autoria da Deputa Carla Zambelli (PSL/SP) que pretende transformar em obrigatória a aplicação do modelo cívico militar a todas as escolas públicas da educação básica, afirma que

\footnotetext{
com o modelo cívico militar, a escola muda sua infraestrutura para atender ao programa, e também a gestão administrativa, que passa a ser feita pelos militares. Ademais, em regra, as propostas pedagógicas das escolas militares têm como objetivo preparar o aluno para a vida em sociedade, formar cidadãos que atuem com ética e cidadania, sendo guiados pelos valores e tradições da educação militar. Além da alta qualidade de ensino, as escolas militares também são reconhecidas pela disciplina e pelas regras de comportamento e vestimenta aplicadas aos alunos (PL 4887/2019. Carla Zambelli - PSL/SP. Grifos meus)
}

Cabe destacar que a instituição das escolas cívico militares não são a plena militarização escolar, mas parte de seu modelo para implementação em escolas 
públicas já existentes. Os valores militares, reconhecidamente associados à disciplina, hierarquia, obediência, ordem e patriotismo, se unem às questões comportamentais e de vestimenta no bojo de suas ações. Apesar do caráter voluntário de adesão, a primeira escola transformada em cívico militar em São Paulo foi inaugurada com protestos. A escola que não atende os critérios utilizados para ser considerada vulnerável foi aprovada para integrar o Programa à despeito da vontade dos pais que protestaram contra a militarização do ensino ${ }^{64}$ (TOMAZELA, 2021).

Outro aspecto a ser discutido é a insistência de que a gestão e o modelo pedagógico militarizados da escola cívico militar emulará àqueles encontrados nos colégios militares. Não apenas o investimento é diferenciado em termos financeiros, como o habitus familiar e escolar dos alunos também o são. Enquanto as escolas militares de fato contam com o financiamento do MEC e do Ministério da Defesa e figuram como instituições de alto investimento em infraestrutura e valorização salarial docente, aquelas que integram o PECIM contam com acordos financeiros entre governo federal, estados e municípios. É necessário militarizar uma escola para torná-la melhor? Por que inserir militares inativos no ambiente escolar se há outros caminhos para o alcance de um modelo escolar de "alto nível"? A contenção da violência parece ser a resposta (RICCI, 2019). Somados, tais elementos permitem alocar o PECIM no guarda-chuva de atuação neoconservadora e inferir sua resistência ao pluralismo e à diversidade comum a seus propositores e defensores.

Nessa categoria também se percebe a influência do movimento Escola sem Partido. Ainda que os projetos de lei homônimos não tenham sido aprovados até o momento, na prática, uma série de ações e declarações de lideranças políticas expressam essa perspectiva, como a postagem de uma deputada estadual de Santa Catarina incitando estudantes a filmarem professores que estejam fazendo manifestações político-partidários ou ideológicas e a "vistoria" surpresa, sem autorização prévia, de dois deputados federais no Colégio Pedro II, no Rio de

\footnotetext{
${ }^{64}$ Primeira escola cívico militar instalada em São Paulo em meio a polêmicas. Disponível em: https://www.terra.com.br/noticias/educacao/primeira-escola-civico-militar-paulista-e-instaladacom-polemica-em-sorocaba,27fe6af9eae8f0fb81790679d392b766ighirdbl.html. $22 / 05 / 2021$.

Acesso:
} 
Janeiro $^{65}$ (BOECKEL; ÁVILA; RODRIGUES, 2019; G1 SC, 2018). Suas propostas estiveram presentes nas promessas de campanha à presidência de Jair Bolsonaro, foram reiteradas pelos ex-ministros da Educação Ricardo Vélez e Abraham Weintraub, pelo atual gestor da pasta, Milton Ribeiro, além da ministra dos Direitos Humanos, Damares Alves.

Damares Alves e Abraham Weintraub chegaram ao ponto de anunciarem, em novembro de 2019, que o governo lançará um canal unificado para receber denúncias de "excessos" e "doutrinação" no ambiente escolar. No entanto, a definição desses termos, bem como possíveis dados estatísticos de suas frequências ou efeitos nunca foram divulgados (RODRIGUES; BOMTEMPO, 2019). Em resposta ao ambiente de vigilância que tomou a educação brasileira, já tem sido noticiados casos de autocensura por parte de professores que temem possíveis punições e demissões por abordarem temáticas ligadas à política, comunismo e a ditadura militar (FAGUNDEZ, 2018). É importante observar que tais demandas aglutinam-se no escopo de defesa dos liberais conservadores, agentes políticos e sociais que conjugam a defesa de pautas morais e políticas conservadoras com a diminuição do Estado e instituição do livre mercado (CUNHA et al, 2017). Outro aspecto relevante é o fato de que investidas desse porte afetam não somente a pluralidade e riqueza da escola como espaço de socialização e construção de conhecimento crítico, como colocam em questão a própria definição de educação pública emancipatória (ROSA, 2018).

O cenário abarcado pela categoria descrita corrobora as reflexões realizadas por Ronaldo Almeida (2017). Segundo o autor, as interações sociais se mostram cada vez mais carregadas de antagonismos à medida que o cenário político se torna cada vez mais permeável às forças e interesses conservadores em assuntos morais, religiosos e sociais. Nesse sentido, Marina Lacerda (2019) aponta que moralidade da família tradicional associada às questões religiosas e demandas por ordem busca atuar sobre o espaço público como uma extensão do domínio privado. Os dados encontrados nesta pesquisa se mostram coerentes com esse entendimento. A partir da percepção e mapeamento de ações que visam diminuir as fronteiras entre âmbitos privados e públicos que nasce a categoria privatização do espaço público (Quadro 14).

${ }^{65}$ A deputada estadual e os dois deputados federais eram filiados ao PSL, o mesmo de Jair Bolsonaro, à época dos fatos descritos. 
Foram identificados o lobby pró ensino religioso confessional, pela interferência de instituições religiosas sobre os currículos do ER na BNNC, e a equiparação de conteúdos científicos como a evolução biológica e a crença criacionista nos currículos de das disciplinas escolares de Ciências e Biologia, o silenciamento das questões de gênero graças à atuação concertada de grupos políticos institucionalizados e movimentos civis reacionários, e a defesa presidencial de combate às ideologias nefastas que impelem a escola à militância política para logo em seguida finalizar sua fala com o Bordão "Brasil acima de tudo, Deus acima de Todos".

Cabe destacar que o domínio público enquanto espaço de sociabilidade, exercício da cidadania e organização institucional de interesses se vê ocupado por múltiplas formas de existências, algumas delas são religiosas. A privatização, ou confinamento da religião aos espaços privados, tal como defendida na Teoria da Secularização já discutida neste trabalho, nunca teria acontecido em sua totalidade. Para José Casanova (1994), a força religiosa extrapola os limites da esfera privada e passa a disputar com instituições laicas poder de atuação no Estado e na sociedade. Esse entendimento é compartilhado por autores nacionais ao discutir as particularidades da laicidade à brasileira (MARIANO, 1999; 2016; CUNHA, 2014; SEPÚLVEDA, 2016).

No que se refere à colonização da educação escolar enquanto ocupação religiosa do espaço público, José Antônio Sepúlveda afirma que

[o Ensino Religioso] é apenas uma das formas de ocupação desse espaço público, amplamente disputado pelas religiões. Há outras maneiras de ensinar religião e ocupar a escola, ainda que não sustentadas por instrumentos legais como a disciplina em questão. A exposição de símbolos religiosos nas salas de diretores, no pátio, a prática de orações realizadas em determinadas situações, missas, bíblias expostas e tantas outras manifestações que privilegiam crenças, também são formas de ensinar (2016, p. 151).

A contínua tentativa de inserir seus preceitos morais particulares na ordem jurídica pública caracteriza, contudo, a atuação ativa do conservadorismo religioso protagonizado por políticos e lideranças cristãs, especialmente evangélicas neopentecostais para além das ambiguidades e porosidades já existentes entre os âmbitos públicos e privados (ALMEIDA, 2017). 


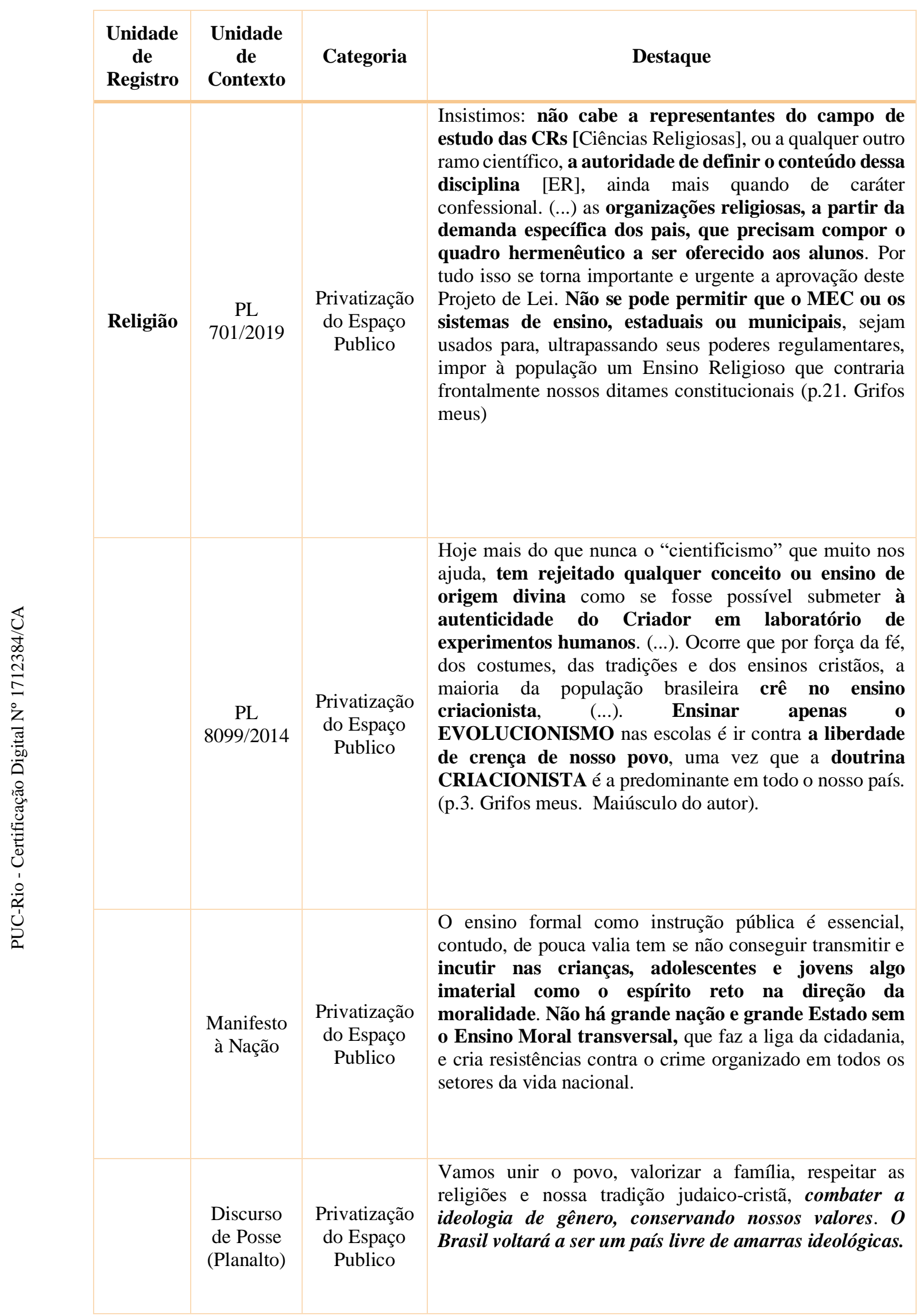

Quadro 11: Destaques relacionados à categoria Privatização do Espaço Público. FONTE: AUTORA (2021). 
Ao refletir sobre a existência de um componente "especificamente religioso" no cenário de crise e ascenção conservadora que vivenciamos, Joanildo Burity (2019) afirma que na conjuntura do impeachment de Dilma Rousseff houve a atuação decisiva de uma elite parlamentar evangélica em conjunto com atores conservadores da sociedade civil e mesmo da Igreja Católica. Entre os grupos organizados é possível destacar a atuação do Movimento Escola sem Partido que busca inclusive subverter a discussão sobre laicidade ao afirmar que a defesa ideológica de esquerda realizada por professores de escola públicas fere o Estado Laico já que é feita com fervor religioso (SEPULVEDA; SEPULVEDA, 2016).

As categorias discutidas até aqui atuam em um sistema de apoio e retroalimentação. A defesa da família e da autoridade familiar atravessa e justifica o combate à diversidade que por sua atua como forma de apagamento dos limites entre o público e o privado dada natureza moral religiosa que lhe inspira. A atuação neoconservadora vem atuando no sentido do apagamento ainda mais potente dos limites entre público e privado que já são ambíguos, tal como aponta a categoria aqui discutida. Acredito ter conseguido argumentar que há em atuação um ativismo educacional moralmente regulador, socialmente intolerante e preocupado com as questões de ordem e valores religiosos. O combate à "ideologia de gênero", a “defesa da família tradicional”, a "demonização do pluralismo e da diversidade" e as demandas por "escolas militarmente organizadas" evidenciam essa atuação.

As marcas ideológicas deixadas por grupos que atuam civil e institucionalmente por uma educação neutra em conteúdos e plena de valores morais, religiosos e tradicionais se assemelham àquelas discutidas por Michael Apple (2002) ao apontar dois dos quatro principais agentes pró neoconservadorismo educacional: os populistas autoritários e os neoconservadores. Enquanto os neo-conservadores pautam suas propostas em um "regresso ao passado" e no "medo do outro", os populistas autoritários se caracterizam pela defesa apaixonada e agressiva de objetivos. Os valores que norteiam ambos os grupos apontados por Apple foram encontrados nos documentos analisados: o "patriotismo", a "ordem", os "ataques ao multiculturalismo", a "moral cristã", a "correta sexualidade", a "família estrutura da sociedade" e o "devido controle do processo de escolarização". Entendo, assim o autor, que tais reinvindicações combinadas apontam para do autoritarismo como ideologia educacional (APPLE, 2002). 


\subsection{Ativismo economicista neoliberal: a educação como insumo}

Embora pouco aparente no levantamento de iniciativas parlamentares no início do capitulo, a influência neoliberal sobre o projeto conservador em curso não deve ser desconsiderada. Sua capacidade de intervenção direta sobre os modos de vida objetivos da população nacional como um todo e, especialmente, sobre os indivíduos pertencente àquelas mais vulneráveis, a torna relevante dentro das discussões que pretendo realizar, por isso essa finalizo a etapa de discussão dos resultado por ela. Os aspectos econômicos da atuação neoconservadora são menos ruidosos do que os de caráter moral e ideológico, e, muito por isso, acabam sendo tratadas institucionalmente sem grande atenção do público em geral. Em sua dimensão econômica liberal, o neoconservadorismo brasileiro se aproxima de posicionamentos pró-Estado mínimo, perspectivas de uberização do trabalho, de corte de políticas públicas e de privatizações (LACERDA, 2019).

Essa pauta ressoa na Teologia da Prosperidade própria de segmentos evangélicos neopentecostais, que enfatiza uma ética individualista, meritocrática e empreendedora (ALMEIDA, 2017), ao mesmo tempo em que, como já discutido, preenche com valores morais sólidos o vazio deixado pelo Estado Neoliberal. Marina Lacerda (2019) aponta que, muito embora os deputados conservadores evangélicos se sintam pouco confortáveis em anunciarem-se como defensores de práticas neoliberais, suas votações favoráveis à mudança da participação da Petrobras na exploração do pré-sal e à definição do teto dos gastos públicos indicam essa adesão ideológica. Contudo, quando se trata da reforma trabalhista, aprovada no Governo Temer, a adesão desses parlamentares diminuiu. Para Lacerda (2019) o recuo se deu por medo do efeito mais imediato que essa pauta causaria na base eleitoral desses parlamentares oriunda das igrejas evangélicas e das camadas populares mais desiguais. Logo, a adesão a uma reforma que impactaria diretamente os direitos de seu eleitor freou o alinhamento dos congressistas conservadores evangélicos aos demais.

Na educação, esta linha de força se expressa, em parte, no avanço de grupos empresariais e da chamada nova filantropia sobre políticas públicas educacionais, na aprovação da Reforma do Ensino Médio (Lei 13.145/2017), da BNCC e do 
programa Future-se (AVELAR, 2019; CORTI, 2019). Nesta seção abordarei o ativismo economicista educacional através das duas primeiras somadas às orientações apresentadas no Manifesto à Nação (FRENTE PARLAMENTAR, 2018). É importante destacar que desde a década de 1990 até o contexto atual, a atuação dos grupos empresariais mencionados é notadamente em defesa de perspectivas mercadológicas da educação. A formação para o mercado de trabalho, o desempenho de estudantes em avaliações internacionais e nacionais como o PISA e a Prova Brasil como quase exclusivamente as únicas medidas possíveis de qualidade da educação e uma visão gerencial da educação, em detrimento de aumento de recursos investidos por aluno, como o Custo Aluno-Qualidade (CARA, 2019) são exemplos dessa atuação. Em janeiro de 2020, o ministro da Economia Paulo Guedes afirmou durante o Fórum Econômico Mundial de Davos, que o governo apoiaria um "gigantesco" programa de vouchers para a primeira infância (VIEIRA, 2020). Formado pela Escola de Chicago, Guedes segue o raciocínio já explicitado anteriormente e que, como já discutido no referencial teórico desta tese, não só parece ter pouco impacto no desempenho educacional dos alunos participantes, como pode aumentar desigualdades sociais já existentes.

Isto posto, passo a discussão da análise propriamente dita. No que se refere aos trechos e contextos da BNCC, é possível identificar atuação conservadora neoliberal por trás não só de sua gestação entre a $1^{\mathrm{a}}$ e a $2^{\mathrm{a}}$ versão, como também se sua modificação na $3^{\mathrm{a}}$ e última versão. Se na última categoria discutida anteriormente argumentei que o espaço público existe como um espaço de atuação e organização cidadã, e que a religião ocupa um lugar nele e disputa por poder de agência, vale o mesmo para o interesse empresarial na educação. Para Vera Maria Vidal Peroni et al (2019), o processo de mercantilização da educação aplica a mesma lógica quando o interesse privado de caráter empresarial define os conteúdos e rumos educacionais. Em suas palavras,

observamos, em parte, o poder público assumindo a lógica do privado na administração pública, através da gestão gerencial e, também, quando abre mão de decidir o conteúdo da educação, repassando a direção para instituições privadas. Nesse caso, a propriedade permanece pública, mas a direção do conteúdo das políticas educativas é repassada para o setor privado. As instituições públicas, se democráticas, são permeáveis à correlação de forças, com processos decisórios em que não se tem previamente o controle do produto. São instituições de propriedade pública, mas se o processo decisório está ausente, já que tudo é previamente definido e monitorado por uma 
instituição privada e os professores apenas executam tarefas, entendemos que este também é um processo de privatização da educação (p.38).

É importante destacar que o já mencionado Movimento pela Base, protagonizada por grandes instituições e grupos empresariais capitaneados pela Fundação Lemann teve grande influência sobre o documento que referencia a aquisição de recursos didáticos, a formação docente, os conteúdos obrigatórios a serem abordados na educação básica como um todo. E foi disputada por agentes neoconservadores reacionários, como o MESP, evidenciando uma disputa dentro da coalização conservadora sobre o projeto de educação e, em última análise, de nação pretendida. Se aos reacionários interessa a defesa de valores morais e controle sobre os comportamentos, aos interesses econômicos interessa os fundos públicos, as parcerias público-privadas, as assessorias especializadas e a produção de materiais didáticos a serem adquiridos pelo Estado (PERONI et al, 2019).

O esvaziamento do caráter democrático deliberativo subvertido na BNCC se deu em plenitude na Reforma do Ensino Médio. Realizada via medida provisória e transformada em lei - sem qualquer margem para debate com a sociedade e as comunidades educacionais- a Lei 13.145/2017 tem enorme impacto sobre o projeto formativo da educação básica nacional pois altera um conjunto de documentos norteadores desse processo: altera as Lei no 9.394/1996 - LDB, Lei 11.494/ 2007 FUNDEB -Fundo de Manutenção e Desenvolvimento da Educação Básica e de Valorização dos Profissionais da Educação, o Decreto-Lei $n^{\circ}$ 5.452/43 Consolidação das Leis do Trabalho - CLT; revoga a Lei no 11.161/05 e institui a Política de Fomento à Implementação de Escolas de Ensino Médio em Tempo Integral (BRASIL, 2017).

Não contemplado na $3^{\text {a }}$ versão da BNCC, o Ensino Médio teve sua etapa homologada apenas em 2018, em um momento posterior à transformação em lei da Reforma do Ensino Médio. Alinhados, ambos redefinem as diretrizes da Política Nacional de Formação de Professores, demandam a revisão do Exame Nacional do Ensino Médio (Enem), do Programa Nacional do Livro e do Material Didático (PNLD) e do Sistema Nacional de Avaliação da Educação Básica (Saeb) ${ }^{66}$. A

66 Ensino Médio tem sua etapa homologada e BNCC está completa. Disponível em: http://portal.mec.gov.br/component/content/article/211-noticias/218175739/72011-etapa-doensino-medio-e-homologada-e-base-nacional-comum-curricular-esta-completa. Acesso em 03/04/2021. 
flexibilização do currículo imposta pela Reforma é mantida na BNCC do EM e aprofunda a clivagem entre os dois segmentos da formação básica nacional: a primeira etapa formada pela educação infantil e o Ensino Fundamental, que corresponderia a uma formação comum a todos os educandos, e a segunda que corresponde ao EM dividido em percursos formativos distintos (Linguagens, Matemática, Ciências da Natureza, Ciências Humanas e Formação Técnica e Profissional). É importante destacar que a Reforma aumenta a carga horária do EM que passa a contar com 3.000 horas totais ao final do processo (1.200 horas voltadas para a formação comum, no qual Português e Matemática constituem disciplinas obrigatórias a todos os itinerários formativos, e 1.800 horas destinadas ao percurso “escolhido" pelo discente).

Nesta seção argumento que o ativismo conservador de natureza econômica altera de maneira sutil o senso comum sobre os significados atribuídos a educação, suas funções e atribuições, tal como discute Michael Apple (2002). As demandas por maior capacidade do Estado em prover bem estar social são cooptadas e transformadas no universo educacional em demandas por maior capacidade formativa para integração no mercado de trabalho. A racionalidade neoliberal que entende a educação como um insumo atua em duas frentes principais: i. o alinhamento da educação às perspectivas de "enxugamento do Estado" e seus investimentos e ii. a individualização do sucesso/fracasso e, portanto, naturalização das desigualdades. A identificação dessas lógicas através da análise de dados permitiu a construção de duas categorias: a educação como comodities (Quadro 15) e o sucesso/insucesso meritocrático (Quadro 16).

A ênfase na educação como um insumo é uma visão da qual lideranças políticas religiosas, em especial evangélicos pentecostais, têm se aproximado de forma mais explícita recentemente. No Manifesto à Nação, há múltiplas referências ao valor do mérito, que seria elemento chave para a superação da doutrinação comunista empreendida na educação pública ao longo dos três últimos decênios, bem como catalisador da inovação tecnológica necessária para que o Brasil deixe de ser apenas um exportador de commodities. Além disso, defende-se a eficientização dos recursos alocados na educação básica e superior, afirmando-se que o custo dos alunos de universidades públicas é excessivamente alto e que seu retorno para a sociedade é pequeno. Ao defender medidas de eficientização, o documento reconhece que o Brasil investe menos por aluno da educação básica do 
que a média dos países da $\operatorname{OCDE}^{67}$ - Organização para Cooperação e Desenvolvimento Econômico (um órgão internacional composto por 37 países membros), embora reitere que os gastos com educação - equivalentes a $6 \%$ do Produto Interno Bruto (PIB) - colocam o Brasil nas posições mais altas de investimento dentre os países que integram a instituição.

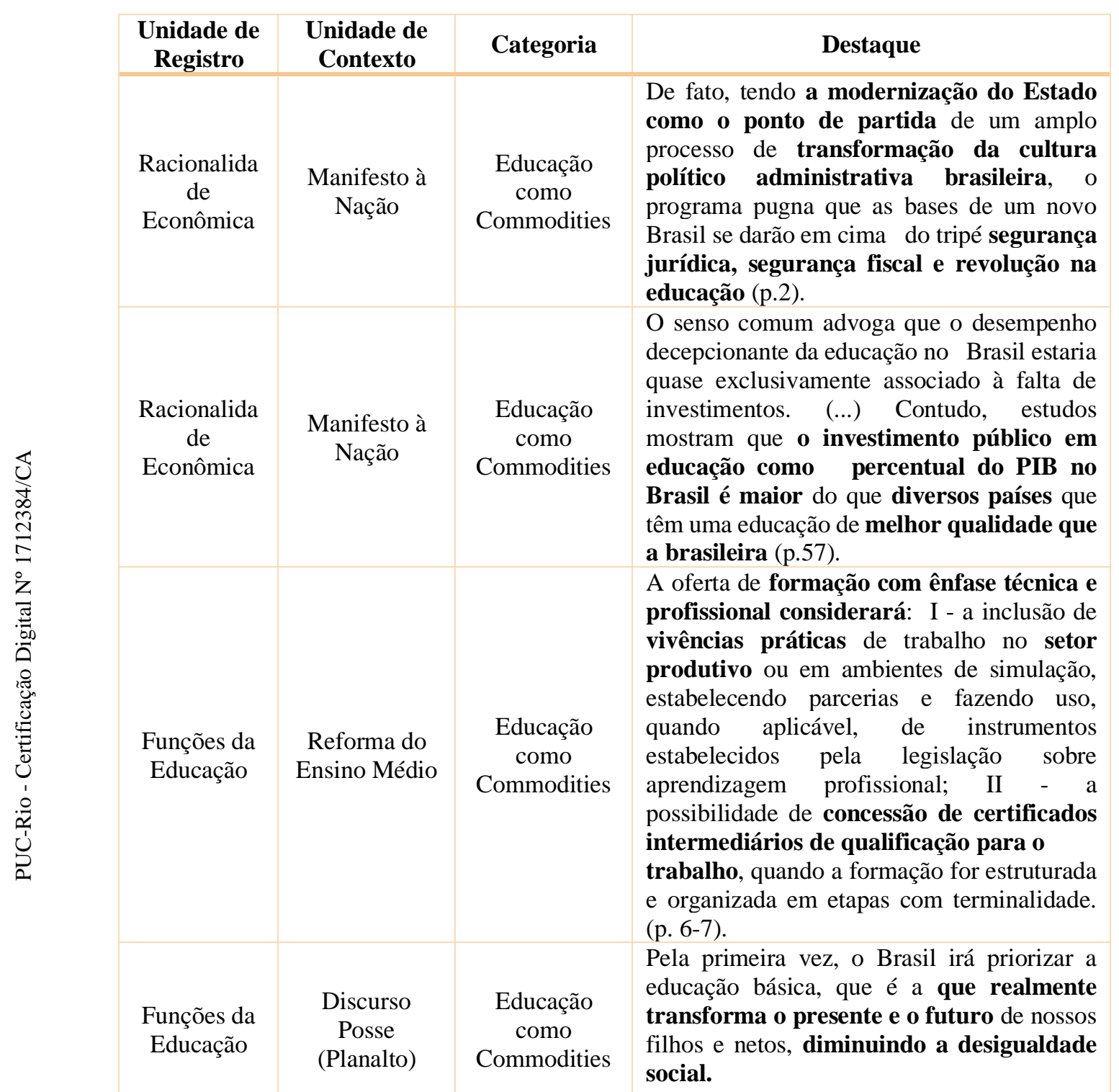

Quadro 12: Destaques relacionados à categoria Educação como Commodities. FONTE (AUTORA, 2021).

${ }^{67}$ OCDE abrange países da Europa, América do Norte, América do Sul e Ásia: Alemanha, Austrália, Áustria, Bélgica, Canadá, Chile, Colômbia, Coreia do Sul, Dinamarca, Eslováquia, Eslovênia, Espanha, Estados Unidos, Estônia, Finlândia, França, Grécia, Holanda, Hungria, Irlanda, Islândia, Israel, Itália, Japão, Letônia, Lituânia, Luxemburgo, México, Noruega, Nova Zelândia, Polônia, Portugal, Reino Unido, República Tcheca, Suécia, Suíça e Turquia. Disponível em: https://www.gov.br/casacivil/pt-br/assuntos/ocde/sobre-a-ocde-1. Acesso em: 12/11/2020. 
De acordo com o Manifesto, não só a análise desenvolvida até o momento não permitiria afirmar com certeza a insuficiência dos desembolsos atuais do setor público em educação, como também indicam gestão ineficiente dos recursos disponibilizados. Nesses termos qualquer comparação com outros países e seus resultados em avaliações internacionais de desempenho, como o PISA, indicaria tal situação. A defesa central é aquela que advoga dedicação à resolução de ineficiências do sistema existente através, principalmente, de mudanças gerenciais (FRENTE PARLAMENTAR EVANGÉLICA, 2018).

A noção de eficiência e melhoria da qualidade de ensino e de investimento no ensino visa fazer "mais gastando menos". Em outras palavras, pretende reorientar o processo formativo para a lógica mercadológica e inserção na cadeia produtiva. A ideia de formar alunos para o mercado de trabalho é antiga e muito discutida pela literatura. A própria LDB (BRASIL, 1996) afirma ser o EM a etapa que deve formar os educandos para a vida em sociedade, o ingresso em níveis superiores de ensino e a inserção futura no mercado de trabalho. A Reforma do Ensino Médio, contudo, distribui de maneira diferenciada o peso e atenção destinadas a cada uma das funções estruturantes do Ensino Médio. Ao instituir uma formação baseada em flexibilizações curriculares de acordo com itinerários formativos e ênfase no percurso profissional técnico - que pode atrair parcerias de instituições educacionais privadas para sua execução - a Reforma se define como uma política pública educacional para a formação de mão de obra e manutenção da cadeia produtiva.

Ao tornar obrigatórias apenas as disciplinas de Língua Portuguesa e Matemática o documento busca se adequar às demandas dos mecanismos avaliativos de larga escala, sejam eles nacionais ou internacionais. Ao optar por um itinerário formativo o educando renuncia a uma gama de conhecimentos contido em outros. Para Michael Apple (2002, 2003), a ênfase da formação para o capital humano, centrada no desenvolvimento habilidades e competências tende a valorizar aquelas mais voltadas paras áreas exatas ou científicas em detrimento daquelas voltadas para as áreas humanas e as artes. Algo que implica não só na redução imediata de conhecimentos a que esses alunos têm acesso, como também os valores associados aos mesmos.

Outra consequência da implementação da Reforma do Ensino Médio no Brasil vem a ser o aprofundamento das desigualdades pré-existentes em semelhança 
à dinâmica de vouchers educacionais já discutida nesta tese. Se nas políticas de financiamento por vouchers os pais tendem a matricular seus filhos em escolas com composição étnica e socioeconômicas similares as suas, aumentando a diferença entre filhos de pais mais escolarizados e menos escolarizados (CARNOY; MCEWAN, 2003), em uma realidade brasileira atravessada por desigualdades socioeconômicas, políticas, culturais e raciais fundantes é mais do que possível inferir que alguns trajetos formativos terão maior adesão que outros, seja por opção dos pais e dos alunos - tendo em mente um ingresso ao mercado de trabalho mais facilitado - seja pelas condições de infraestrutura dos espaços escolares - que determinaram a oferta dos itinerários formativos. Essa lógica ecoa na segunda categoria elencada: o sucesso/insucesso meritocrático.

Nesta categoria é possível observar duas dimensões: a individual e a coletiva. Enquanto a primeira trata das possibilidades de sucesso ou insucesso dos indivíduos por meio da educação, na segunda as implicações são macroestruturais e se referem ao sucesso/insucesso do Brasil enquanto potência mundial. O discurso de posse de Jair Bolsonaro evidencia a primeira, enquanto o Manifesto aborda ambas. A política educacional instituída pela Reforma do Ensino Médio pode ser vista como a materialização prática destas orientações.

Esses achados corroboram as reflexões de Ronaldo Almeida (2017) sobre a atuação da linha de força econômica conservadora que, para o autor, age em duas frentes: lobby pró diminuição do Estado e celebração do esforço próprio e da disposição empreendedora, esta última alinhada a ideais religiosas de prosperidade. Em atuação educacional, o ativismo economicista busca, nesse mesmo sentido, diminuir a capacidade do Estado de investir como se deve sobre à educação e transferir para os alunos a responsabilidade pelo seu próprio sucesso e, em última análise, da sociedade como um todo. É interessante pontuar, no entanto, que a ética econômica adotada se trata de um neoliberalismo que não dispensa totalmente o Estado, ao contrário, exige dele o papel de regulador, avaliador, mantenedor de parcerias público/privadas, mas esse papel é um papel menor, mais enxuto e permeável as lógicas empresariais e ethos religioso. 


\begin{tabular}{|c|c|c|c|}
\hline $\begin{array}{c}\text { Unidade de } \\
\text { Registro }\end{array}$ & $\begin{array}{c}\text { Unidade } \\
\text { de } \\
\text { Contexto }\end{array}$ & Categoria & Destaque \\
\hline $\begin{array}{l}\text { Racionalidade } \\
\text { Econômica }\end{array}$ & $\begin{array}{c}\text { Manifesto } \\
\text { à Nação }\end{array}$ & $\begin{array}{c}\text { Sucesso/ } \\
\text { Insucesso } \\
\text { Meritocrático }\end{array}$ & $\begin{array}{l}\text { Valorizar e incentivar o mérito em todo o sistema } \\
\text { educacional nacional como condição do sucesso } \\
\text { individual e, por extensão, no sucesso do Brasil. A } \\
\text { tragédia que se instituiu no Brasil nas últimas } \\
\text { décadas teve como uma das causas o desprezo } \\
\text { pelo esforço, pelo estudo, pelo mérito } \\
\text { conquistado ao longo do tempo, em benefício do } \\
\text { caminho mais curto da demagogia, do uso } \\
\text { político-partidário das escolas e universidades } \\
\text { públicas (...) (p.53). }\end{array}$ \\
\hline $\begin{array}{c}\text { Funções da } \\
\text { Educação }\end{array}$ & $\begin{array}{l}\text { Manifesto } \\
\text { à Nação }\end{array}$ & $\begin{array}{c}\text { Sucesso/ } \\
\text { Insucesso } \\
\text { Meritocrático }\end{array}$ & $\begin{array}{l}\text { Educação é sistema insustentável ou } \\
\text { sustentável. A sustentabilidade se forma quando } \\
\text { todo o sistema se baseia na meritocracia. É isso } \\
\text { que colocará o Brasil no grupo das nações mais } \\
\text { desenvolvidas do mundo, pois a Ciência \& } \\
\text { Tecnologia são resultado da Educação. (Grifos } \\
\text { meus) }\end{array}$ \\
\hline \multirow[t]{2}{*}{$\begin{array}{c}\text { Funções da } \\
\text { Educação }\end{array}$} & $\begin{array}{l}\text { Discurso } \\
\text { Posse } \\
\text { (Planalto) }\end{array}$ & $\begin{array}{c}\text { Sucesso/ } \\
\text { Insucesso } \\
\text { Meritocrático }\end{array}$ & $\begin{array}{l}\text { Daqui em diante, nos pautaremos pela vontade } \\
\text { soberana daqueles brasileiros: que querem boas } \\
\text { escolas, capazes de preparar seus filhos para o } \\
\text { mercado de trabalho e não para a militância } \\
\text { política; que sonham com a liberdade de ir e vir, } \\
\text { sem serem vitimados pelo crime; que desejam } \\
\text { conquistar, pelo mérito, bons empregos e } \\
\text { sustentar com dignidade suas famílias; que } \\
\text { exigem saúde, educação, infraestrutura e } \\
\text { saneamento básico, em respeito aos direitos e } \\
\text { garantias fundamentais da nossa Constituição. } \\
\text { (Grifos meus) }\end{array}$ \\
\hline & PECIM & $\begin{array}{c}\text { Sucesso/ } \\
\text { Insucesso } \\
\text { Meritocrático }\end{array}$ & $\begin{array}{l}\text { O currículo do ensino médio será composto pela } \\
\text { Base Nacional Comum Curricular e por } \\
\text { itinerários formativos, que deverão ser } \\
\text { organizados por meio da oferta de diferentes } \\
\text { arranjos curriculares, conforme a relevância } \\
\text { para o contexto local e a possibilidade dos } \\
\text { sistemas de ensino, a saber: I - linguagens e suas } \\
\text { tecnologias; II - matemática e suas tecnologias; } \\
\text { III - ciências da natureza e suas tecnologias; IV - } \\
\text { ciências humanas e sociais aplicadas; V - } \\
\text { formação técnica e profissional (p.5.Grifos meus). }\end{array}$ \\
\hline
\end{tabular}

Para Michael Apple (2002), tornar função da educação adequar os alunos a um mundo mais competitivo enquanto atrela o sucesso e capacidade de sucesso econômico e superação de desigualdades romantiza as condições a distribuição desigual de recursos, bem como terceiriza as responsabilidades pela resolução mazelas sociais existentes. Ao esperar dos egressos de um EM marcado por uma estrutura curricular flexibilizada e acesso desigual aos diferentes itinerários formativos uma rápida inserção na cadeia produtiva e, no caso dos mais aptos e merecedores de seguir estudando, nos níveis superiores de ensino, as forças de 
atuação neoconservadoras atuam na manutenção e aprofundamento das desigualdades sociais e educacionais existentes.

Nesta seção argumentei que o ativismo educacional economicista atua em duas dimensões principais que trazem enormes consequências para um projeto educacional que se pretenda emancipatório: a diminuição do Estado, através do discurso da eficiência e modernização, e a celebração do mérito como fator de sucesso individual e coletivo. As implicações desses encaminhamentos aumentam o apagamento de fronteiras entre espaço público e âmbito privado e explicitam a influência religiosa político institucional, especialmente representada pela Frente Parlamentar Evangélica e sua subdivisão, a Bancada Cristã Evangélica. Somados, os achados discutidos ao longo desse capítulo apontam uma atuação neoconservadora por coalizão de indivíduos e articulação de interesses que hora se aproximam, ora se afastam, ora se articulam em uma conformação diferente de maneira relacional ao objeto em questão.

Essa dinâmica pode ser visualizada através da convergência de interesses entre grupos empresariais filantrópicos e conservadores em determinadas pautas econômicas e a ausência de convergência em pautas morais, socialmente intolerantes e securitárias. A implantação do modelo de escolas cívico-militares e ao combate ao ensino de questões de gênero e diversidade sexual, por exemplo, são criticadas pelo movimento Todos pela Educação, embora fortemente defendidos por militares, evangélicos e católicos (FERREIRA, 2019b; MATARAZZO; GONÇALVES, 2019). Tal divergência já tinha sido observada no processo de tensionamento da aprovação da BNCC (SEPULVEDA; SEPULVEDA 2016) e no início do Governo Bolsonaro em relação à indicação de Mozart Ramos, diretor do Instituto Ayrton Senna, para assumir o ministério da educação do governo Bolsonaro e, posteriormente, o veto ao seu nome pela bancada evangélica (MURAKAWA; DELGADO, 2018).

Retorno a Michael Apple (2002) para refletir tal dinâmica. Muito embora possa causar estranhamento, é esperado que uma coalização tão diversa em integrantes e objetivos apresente divergências em determinadas pautas e se aproxime em outras mais comuns. Para o autor, assim como na política, a articulação pró modernização conservadora se mantém em um dinâmico fluxo de equilíbrio. Enquanto os neoliberais necessitam de um Estado fraco, pouco empenhado em resolver as demandas de bem estar social da população, os neo- 
conservadores demandam um Estado forte na regulação dos comportamentos. Se a classe média nem sempre endossa o neoconservadorismo religioso e pode se afastar em determinado momento de estabilidade econômica, em uma situação de crise econômica retornam ao autoritarismo populista. Ao prover apoio às investidas neoliberais e aos arroubos autoritários neoconservadores de fundo moral e religiosos no cenário educacional, tal grupo, mesmo sem endossar as ideologias extremas dos demais, acredita que sua capacidade de mobilidade e ascenção podem ser favorecidas em tal aliança. A ideia de um ambiente e currículo escolar de "alto nível" somados à preocupação com a inserção no mercado de trabalho e medo do rebaixamento de status social em um mundo incerto ou em crise favorece a adesão destes sujeitos a perspectivas políticas, culturais e educacionais conservadoras.

Acredito que esta pode ser uma das explicações para o sucesso do espraiamento neoconservador sobre a sociedade em geral, e, especialmente, sobre o campo educacional. A incerteza gerada por crises econômicas e ampliada por agentes conservadores empenhados em combater todo tipo de modo de vida e pensamento contrários aos seus ecoou nos medos e inseguranças das diferentes classes sociais, fazendo-as tender mais e mais ao conservadorismo político, econômico, religioso, cultural, moral e educacional. Pretendo abordar essa e outras questões empiricamente em desdobramentos futuros. Por ora, finalizo a discussão dos resultados e passo a seção de considerações finais a seguir. 


\section{Considerações finais}

Esta pesquisa teve como principal interesse mapear a atuação neoconservadora sobre a educação brasileira ao longo das últimas duas décadas. A hipótese inicial desta investigação partia do princípio de há em curso um movimento político (e cultural) institucionalizado que visa cooptar a campo educacional e esvaziá-lo de seu potencial emancipatório. Para tanto, os diferentes agentes envolvidos em tais processos utilizariam discursos e ações de cunho moral, religioso, meritocráticos e securitários. A fim de testar sua validade, optei por analisar as lógicas, valores e interesses materializados em diferentes tipos de documentos, tais como contextos políticos e trechos silenciados, levantamento de projetos de leis e demais iniciativas parlamentares, discursos e decretos presidenciais.

Tais escolhas não foram feitas de maneira aleatória, ao contrário, buscaram responder as questões norteadoras deste estudo, a saber: "Quais os agentes, discursos e objetivos relacionados à lógica conservadora brasileira na educação? Que valores e objetivos os movem? Qual é o lugar ocupado pela religião nesse contexto político e social?". Acredito que o resultado foi bem-sucedido. Antes de chegar até ele, no entanto, um importante caminho foi percorrido. Como primeira etapa deste percurso foi preciso caracterizar o estava senda sendo chamado de "contexto de ascensão do conservadorismo" e quais as referências teóricas seriam utilizadas para analisá-lo.

No que se refere a caracterização mencionada, ficou estabelecido que as demandas por maior capacidade de moralização das relações sociais por parte do Estado somadas à defesa do rigor punitivista, ao aumento de antagonismos sociais de origem político religiosa e ao combate às políticas de redistribuição e reconhecimento aumentaram em expressão e visibilidade o grau de atuação neoconservadora no Brasil nos últimos anos (TATAGIBA, 2018). Pela importância social que possui, a educação como um todo e, em especial, a escola pública foram apontadas como locais potencialmente perigosos dada a capacidade de promover valores, instruir em conhecimentos, sociabilizar sujeitos e abrigar diferentes perspectivas de vida entre seus muros às demandas conservadoras anteriormente descritas (PENNA, 2017; SANTOS, 2018; LIMA; HYPÓLITO, 2019). 
Sobre o referencial teórico utilizado para analisar o fenômeno do neoconservadorismo educacional, três frentes principais foram utilizadas: a definição do que de fato vem a ser o conservadorismo e suas principais escolas a partir, especialmente, de Noel O’Sullivan (2013); a discussão das principais características do novo conservadorismo brasileiro, suas semelhanças e diferenças com o movimento de mesma natureza ocorrido em contexto estadunidense nas décadas de 70 e 80 realizada segundo as reflexões apresentas por Marina Lacerda (2019) e as linhas de força em que se divide a onda conservadora que se quebra sobre o Brasil, segundo Ronaldo Almeida (2017), e, por fim, a discussão trazida por Michael Apple de que as investidas neoconservadoras no campo educacional buscam produzir uma relação pautada pelo consumo, redefinição de fronteiras entre espaço público e privado ao mesmo tempo em que promove um duro processo de moralização religioso dos corpos e comportamentos (APPLE, 2003).

Entendo que por ser comumente utilizado como um insulto ou um "autoelogio" a depender dos interlocutores, os polissêmicos termos "conservador" e "conservadora", precisam ser bem definidos para serem usados como conceitos analíticos. O mesmo vale para o movimente ao qual remetem, o conservadorismo. A fim de preencher essa lacuna, busquei em Noel O'Sullivan (2013) os elementos necessários para reconstruir a história e as escolas de pensamento ditas conservadoras. Para o autor, quatro destas escolas podem ser apontadas, conforme já discutido. Em síntese, a escola reacionária aponta como base estruturante da sociedade o consenso entre as instituições políticas e os valores morais e religiosos fundamentais. Já para a escola radical, um conservadorismo que se pretende relevante deve abraçar a modernidade democrática e investir em líderes capazes e carismáticos que unifiquem a população e o Estado frente as divisões sociais e lutas de classe. A terceira, por sua vez, é chamada de moderada buscar o comprometimento com um ideal de Estado limitado e regido pela lei; existência de instituições representativas e de uma constituição que controle o poder executivo. Algo que no espectro conservador, pode se inserir entre a apatia social defendida pelos reacionários e a mobilização ativa das massas desejada pelos radicais. A última escola, chamada de Nova Direita ou Neoconservadorismo, teria surgido em resposta ao Estado de Bem Estar Social.

A ascensão ao poder da Nova Direita nos EUA, segundo O'Sullivan (2013), impactou a política e a história não somente daquele país entre os anos 1970 e 1980, 
como ainda hoje reverbera por lá e em outros países. Nesta tese sustento que esse é o caso do Brasil. A partir desse entendimento, trago as discussões de Marina Lacerda (2019) para a segunda frente teórica utilizada nesta investigação. Para Lacerda, o neoconservadorismo enquanto movimento político norte-americano reuniu sob um mesmo guarda-chuva dois lados aparentemente distintos: os grandes representantes da elite econômica, preocupados em reestabelecer seu poderio de classe, e uma considerável parcela da classe trabalhadora, carregada de tradicionalismo moral. Sobre essa última, o pentecostalismo religioso, especialmente representado pela Direita Cristã, teria tido grande influência. Constituída por evangélicos e ligada à renovação carismática católica, a Direita Cristã investiu em estrutura organizacional, capilaridade social e capacidade de mover as massas religiosas em torno dos valores neoconservadores. O vínculo entre política (à direita), religião (patrulhamento moral), práticas neoliberais (diminuição do Estado) e demandas punitivistas (aumento da repressão policial e máximo rigor judiciário na política interna e ativismo anticomunista na externa) explicita as principais bandeiras neoconservadoras nos EUA da década de 1980.

Para Lacerda (2019), o Brasil atual adapta as bandeiras neoconservadoras descritas e às atualiza ao momento que vivemos. A defesa da família tradicional patriarcal, a ênfase neoliberal por menos Estado, o lobby pró-armamento e pródiminuição da maioridade penal, o rechaço à suposta ameaça comunista oferecida por vizinhos latinos e o alinhamento à Israel em sua política externa exemplificam essa dinâmica. Ronaldo Almeida (2017), por sua vez, afirma que forças moralmente reguladoras de forte influência cristã, economicamente alinhadas ao neoliberalismo, socialmente intolerantes e ávidas por questões securitárias compõem a onda conservadora que se quebra sobre o país ao discutir as linhas de atuação conservadora em atuação. Ambos sustentam para enfrentar o crescente conservadorismo é preciso conhecer suas estratégias, intenções e agentes que se articulam em reação aos avanços obtidos por políticas de reconhecimento e redistribuição de renda.

A última frente teórica utilizada é composta pelas reflexões de Michael Apple $(2002 ; 2003)$ sobre a atuação neoconservadora educacional. Para o autor, os ataques aos valores pluralistas e democráticos no plano educacional assume tons ora moralizantes, ora securitários, ora economicistas. Termos como "competividade" e "eficiência" operam associados a conflitos culturais e dinâmicas 
subalternização de raça e gênero em diferentes espaços, tais como discursos políticos, propagandas empresárias, editoriais jornalísticos. Assim a educação e as políticas públicas educacionais figuraram como mais um desses locais, assumindo, porém, um lugar de enorme relevância dada sua capacidade de difundir valores e saberes. A "modernização educacional conservadora" utilizada nesta tese resulta de um processo social maior, a "restauração conservadora", que, segundo Apple (2002) é a materialização da coalizão entre diferentes grupos da direita política norte-americana.

Acredito que a primeira contribuição desta tese se refere à construção do referencial destacado. A preocupação em explicar de maneira histórica e relacional os elementos que compõem o neoconservadorismo como um todo e seu interesse sobre à educação oferece ao campo de pesquisa um arcabouço teórico ricamente informado sobre um tema em crescente relevância atualmente. Outra contribuição a ser considerada seria a estrutura metodológica desenvolvida. Tendo por principal objetivo mapear a atuação conservadora sobre a educação, como já informado, as escolhas relacionadas aos procedimentos metodológicos e aos objetos de análise foram realizadas com um único intuito: potencializar o encontro de respostas que ultrapassam os sentidos imediatos oferecidos por uma leitura comum e pouco qualificada e, assim, expandir os limites do conhecimento até então existentes sobre o fenômeno estudado (BARDIN, 2016; DENZIN; LINCON, 2006).

Assim foram elencados os seguintes materiais a serem analisados:

i. Um levantamento de iniciativas parlamentares relacionados à educação de forma direta ou que a utilizasse como componente retórico/argumentativo relevante propostas na Câmara de Deputados do Congresso Nacional entre os anos 2001 e 2020, produzido inicialmente junto ao grupo de pesquisa ao qual pertenço, o Diversias, e, posteriormente, amadurecido ao longo de minhas próprias investigações.

ii. Os contextos e trechos do PNE, da BNCC e da Reforma do Ensino Médio. Políticas públicas educacionais anteriores ao atual governo que ganharam destaque nacional pelos processos tortuosos e polêmicos de criação, gestação e homologação.

iii. Um grupo de documentos mais próximo do Governo Bolsonaro, o PECIM, seus discursos de posse e o Manifesto à Nação produzido pelas lideranças 
religiosas da Frente Parlamentar Evangélica durante o processo eleitoral de 2018.

A opção de analisar estes documentos se deu por motivos específicos: a busca por temáticas, indivíduos, partidos, grau de associações entre proponentes e demais aspectos relacionados ofertados pela análise de proposições parlamentares, a compreensão dos argumentos e valores mobilizados nos discursos e manifestos, e, a tentativa de identificar os valores por trás de uma política pública em andamento ou já implementada, as negociações e os silenciamentos presentes em seus textos.

Ao analisar as iniciativas parlamentares de maneira quantitativa pude observar certa dinâmica reativa caracterizada por aumentos de pautas conservadoras em um posterior a um período de maior demanda progressista. Também foi observado o aumento de propostas consideradas conservadoras após a cooptação dos protestos movidos por insatisfação popular em 2013 e, ainda mais, após o afastamento da presidenta Dilma Rousseff em 2015. O ápice de iniciativas desta natureza ocorre em 2019, primeiro ano do Governo Jair Bolsonaro, ex-militar, conservador autodeclarado e intimamente relacionado com líderes religiosos neopentecostais.

A partir dessa percepção é possível inferir que a atuação progressista em maior expressividade, ou mesmo um governo mais à esquerda no plano político, agite as bases conservadoras e as impele à ação no sentido contrário, ou seja de contenção de possíveis avanços de pautas às quais se opõem. Muito embora, seja preciso destacar que a atuação conservadora não se mostrou hegemônica, dado à identificação de proposições mais alinhadas às pautas pluralistas, pró-diversidade e laicas, e ao fato de que apesar no número de proposições nenhuma foi transformada em lei até o momento. Ainda que seja possível apontar limites à categorização das iniciativas como conservadoras e progressistas, dada a amplitude e polissemia destes conceitos, acredito que seu potencial de organização das proposições dentro do grande espectro político existente a partir de suas tendências mais proeminentes justifique tal opção.

Sobre os temas abordados com maior frequência segundo cada categoria, as temáticas conservadoras versaram em maioria sobre questões ligadas à sexualidade, seguidas de pautas relacionadas à religião, ao lobby pró-educação domiciliar, ao combate à doutrinação docente e às perspectivas de ordem via militarização do espaço escolar. Em contraponto, iniciativas consideradas progressistas voltaram-se 
também à sexualidade, à religião em termos diversos e laicos, à educação pluralista e democrática e ao combate à militarização educacional. Esses achados evidenciam os diferentes projetos de democracia e perspectivas de vida em sociedade em jogo, assim como o próprio papel da religião nestes contextos.

Foram também encontradas proposições consideradas ambíguas. É importante ter em mente que mesmo entre as demais categorias, é necessário entender o quadro de atuação conservadora como um espectro em constante construção entre polos considerados mais ou menos conservadores/progressistas. As iniciativas ambíguas foram assim categorizadas por possuírem textos pouco claros em relação à sua filiação ideológica e/ou articularem pressupostos considerados progressistas em proposições que deixam margem de dúvidas quanto a sua aplicação prática.

Duas questões emergem da análise dessa categoria: as implicações para a laicidade e a possível utilização de subterfúgios para esconder interesses conservadores. Sobre a primeira, recai o entendimento de que as diferentes interpretações sobre o que de fato é um Estado laico, o papel e lugar da religião na sociedade, decorrem, em grande medida, das diferentes agendas e visões de mundo, das bases epistemológicas utilizadas e interesses sociais e institucionais defendidos. Assim como Ricardo Mariano (2016), acredito que delimitar as funções do Estado laico implica necessariamente legitimar o tipo de atuação religiosa que permitida nos espaços públicas e esferas de poder. Daí a ferrenha disputa em torno deste poder. Já sobre a segunda questão, é preciso refletir sobre a instrumentalização de proposições de teor supostamente neutro de modo a ocupar o espaço daquelas mais comprometidas com reflexões plurais que ultrapassam as questões sobre segurança e defesa dos vulneráveis, especialmente em iniciativas relacionadas à sexualidade e à religião em contextos educacionais.

Quanto à análise qualitativa dos materiais como um todo, pude estabelecer duas formas de atuação principais: a moralmente reguladora, securitária e socialmente intolerante - que conjuga disposições religiosas no patrulhamento de questões sobre diversidade, funções educacionais e apagamento das fronteiras público/privadas - e a economicista neoliberal - que atua de modo a diminuir o tamanho do Estado, seus investimentos e atribuições relacionadas à educação, e a celebração meritocrática do esforço como indicador de sucesso individual e coletivo. É interessante observar que os resultados encontrados dialogam com os 
achados obtidos na revisão bibliográfica. Através dela foi possível observar que a educação pode ocupar duas posições em discussões relacionadas ao neoconservadorismo: a centralidade - os textos se dedicam a discutir sobre os processos educacionais e as disputas entre as forças sociais por seu direcionamento - ou a retórica argumentativa - a educação é apontada como um importante espaço (e perigoso) para difusão de valores. Ambas expressam preocupações e interesses relacionados à capilaridade educacional, sobretudo escolar. Nos dados discutidos nesta pesquisa de doutorado é possível observar a disputa em torno dos sentidos atribuídos ao processo educacional e suas funções.

As temáticas recorrentes encontradas nos documentos nacionais e internacionais trazidos na revisão bibliográfica guardam semelhanças com aquelas discutidas nesta investigação: a diversidade sexual/cultural como elemento a ser combatido, a relevância da moralidade religiosa e sua influência sobre comportamentos e direcionamentos, os valores tradicionais como elementos estruturantes da atuação civil e institucional pró-conservadora em diferentes segmentos sociais. As consequências da diminuição dos limites entre público e privado, segundo os textos que evocam resistência às investidas neoconservadoras, exigem o reposicionamento da educação como um espaço de enfrentamento pautado pela pluralidade de ideias e práticas de empoderamento e criticidade.

Trago este mesmo argumento e o expando a partir dos dados discutidos: para sobreviver ao neoconservadorismo educacional é preciso conhecê-lo em seus fundamentos, reconhecer suas lógicas, compreender os mecanismos empregados por seus agentes e, a partir desse conhecimento, construir movimentos que não só resistem aos seus assaltos, como também atuam em seu combate. Uma das possibilidades decorrentes deste movimento é a construção de chaves de leitura da atuação conservadora sobre disciplinas escolares específicas que figuram como fonte espaços estratégicos aos interesses conservadores para a difusão de seus valores e visões de mundo, tais como as disciplinas das áreas de Ciências Humanas, o Ensino Religioso e à educação em Ciências e Biologia. Assim como a inserção e o aprofundamento de discussões políticas (não partidárias) na formação inicial e continuada dos professores das diferentes disciplinas existentes.

Em síntese, a atuação neoconservadora voltada para a educação ao longo dos últimos 20 anos foi mapeada e discutida neste trabalho de tese e apontou: i. a dinâmica reativa das proposições conservadoras que crescem na tentativa de conter 
avanços que lhes são contrários, com ênfase na regulação de corpos e afetos a partir de perspectivas religiosas cristãs, ii. a atuação moralmente reguladora, socialmente intolerante e sedenta por ordem e militarismo se mostra preponderante nos documentos analisados, e, iii. a atuação economicista neoliberal, apesar de sutil em suas ações, pode impactar diretamente o tipo e a qualidade do projeto educacional brasileiro. Apesar do muito realizado, acredito que ainda existe muito o que fazer com os dados levantados. Como desdobramento futuro desta investigação pretendo me debruçar sobre minha própria área de formação inicial e atuação profissional, as disciplinas escolares Ciências e Biologia dada a relevância que elas assumem no contexto de disputa pela hegemonia educacional. Apresento aqui, de maneira ensaística e reflexiva, as principais linhas deste argumento a ser desenvolvido.

Ao tratar temas como sexualidade humana, evolução biológica, origem da vida e natureza do conhecimento científico, por exemplo, as disciplinas Ciências e Biologia apresentam grande potencial de conflito com ideais conservadores, especialmente com aqueles religiosamente inspirados (DORVILLÉ et al, 2015; MATTOS et al, 2016; BORBA et al, 2019). Antes de me aprofundar sobre as implicações desses embates acredito ser necessário fazer alguns apontamentos sobre a área em questão. Em primeiro lugar é preciso destacar a complexidade de definir o que é e o que não é Ciência afinal e porque isso é relevante para a temática discutida até aqui. Segundo Cachapuz et al (2011), essa tarefa envolve debates não consensuais sobre sua própria natureza e epistemologia. De um lado, encontram-se aqueles que apontam a pouca veracidade encontrada em um entendimento de Ciência como um conjunto de conhecimentos neutros e racionalmente sistematizados sobre a realidade, cuja obtenção dar-se via rígida aplicação metodológica experimental. Do outro, estão aqueles que seguem apontando a capacidade explicativa, e mesmo preditiva, da atividade científica tanto para fenômenos naturais como sociais.

Isoladas e levadas ao extremo, tais críticas podem produzir tanto um relativismo negacionista do conhecimento científico, quanto uma visão determinista e supervalorizada de suas capacidades, respectivamente (LACEY, 1998). Conjugadas, entretanto, permitem a compreensão da ciência como uma instituição social - influenciada pelas condições materiais e históricas - que busca compreender, manipular e intervir sobre a realidade que se debruça. O saber científico entendido nesses termos constitui-se como uma forma de conhecimento 
que se distingue de outras por possuir bases epistemológicas diferenciadas, pressupostos teóricos e metodológicos que lhe garantem certos níveis de atuação e potencial explicativo (CHALMERS, 1994; LACEY, 1998; AULER; BAZO, 2001; ANDERY et al, 2014). É importante ter em mente, no entanto, que apesar de ser uma atividade humana atravessada por forças econômicas e sociais, assumir uma postura relativista sobre a ciência abre espaço para entendê-la como apenas mais uma forma de opinião, conhecimento ou ideologia (LEWONTIN, 2000).

Num país em que as forças conservadoras ocupam os maiores cargos políticos, advogam o descumprimento de medidas sanitárias e a utilização de medicamentos comprovadamente ineficazes ${ }^{68}$ ao mesmo tempo em que insuflam a população contra supostas ideologias de gênero e doutrinárias que pervertem valores morais familiares nas escolas na tentativa de desviar atenções ${ }^{69}$, a adequada educação em Ciências e Biologia da população se mostra especialmente necessária. A pandemia, que atualmente se espalha pelo planeta e encontra no Brasil espaço ceifar milhares de vidas, reacendeu os debates sobre a importância do conhecimento científico e da adequada educação em Ciências por parte da população.

A disseminação de notícias falsas, as "Fake News", avançam por todo território nacional e prejudicam em demasia o manejo da situação: "vírus construído em laboratórios com intenções militares", "uso obrigatório de máscaras: efetivamente protetor ou sinônimo de intromissão política indevida sobre os direitos individuais?", "vacinas: aliadas ou vilãs?"70. Essas discussões se somam àquelas como o terraplanismo e o negacionismo climático em ambientes de rápida disseminação e pouca ou nenhuma checagem de informações. Abordagens deste tipo vem utilizadas por grupos conservadores de diferentes origens na tentativa de tensionamento das discussões políticas e sociais (CAPONI, 2020).

Tais perspectivas buscam adentrar o cotidiano escolar via espaço no currículo e disputar narrativas sobre a realidade há algum tempo. Segundo Dorvillé

68 O negacionismo científico do Presidente brasileiro, Jair Bolsonaro. Disponível em https://oglobo.globo.com/brasil/o-negacionismo-do-presidente-bolsonaro-em-imagens-ao-longode-um-ano-de-pandemia-24919812. 15/04/2021

69 Bolsonaristas testam terreno para aprovação de projetos conservadores. Disponível em. https://www1.folha.uol.com.br/cotidiano/2021/05/bolsonaristas-testam-terreno-para-projetosconservadores-na-camara.shtml. Acesso: 25/05/2021.

$\begin{array}{lllll}70 & \text { Polêmicas } & \text { relacionadas à Covid19. Disponível }\end{array}$ https://www.uol.com.br/vivabem/noticias/deutsche-welle/2020/09/18/de-virus-criado-na-china-avacina-faz-mal-as-mentiras-sobre-a-covid-19.htm Acesso em: 20/08/2020 
et al (2015), é através do emprego de uma retórica pró educação plural e pró debate entre diferentes opiniões e conhecimentos que grupos notadamente intolerantes "procuram, na verdade, defender a inserção das interpretações particulares de alguns segmentos religiosos no currículo prescrito e nos materiais escolares de ciências e biologia” (p.72). Nesse contexto, pensar a educação científica e biológica torna-se não somente relevante, como fundamental a construção de uma sociedade que se queira plural e ciente do que é a Ciência, suas implicações práticas e utilizações retóricas na vida em sociedade.

Algumas ponderações são necessárias, no entanto, antes de prosseguir: $\mathrm{O}$ que de fato vem a ser a educação em Ciências e Biologia? O que se espera dessas disciplinas? Por que elas incomodam a lógica conservadora e figuram como espaços a serem dominados? As respostas essas e outras perguntas perpassam pelo entendimento da função social da educação e da escola. Sem esquecer da imediata demanda por políticas públicas que busquem reformulações estruturais dos currículos das diferentes disciplinas num sentido emancipatório, Giroux (1997; 2012) aponta a centralidade da escola, bem como do papel docente, no processo de educar para plena atuação social em sociedades democráticas, levando os educandos a adquirir e produzir condições de repensar suas ações de maneira ética. De maneira geral, a função social da escola está vinculada à formação de sujeitos potencialmente mais capazes de mobilizar valores e construir conhecimentos que lhes auxiliem na atuação efetiva em uma sociedade assimétrica.

Ora, se a educação emancipatória pretende ajudar seus educandos a construir conhecimentos e mobilizá-los de maneira criticamente orientada, a que se propõe a educação conservadora? No que ela impacta a educação em Ciências e Biologia? Retornarei a esse questionamento adiante, antes é preciso esclarecer alguns aspectos sobre estas disciplinas.

Sobre a educação em Ciências e Biologia, Marandino et al (2009) apontam que a disciplina escolar Ciências, nascida no Brasil em 1930, apresenta duas dimensões desde a sua origem: i) de um lado guarda relações com o ideal positivista de um método científico único que uniria as ciências de referência (Biologia, Física e a Química), e ii) do outro sustenta-se na ideia de utilidade social de seus conhecimentos. A partir dessa dinâmica, as autoras apontam que a disciplina ciências assumiu ao longo do tempo tanto a função de introduzir às ciências, de maneira geral, como também, passou a legitimar a utilidade de seus conhecimentos 
no cotidiano e na formação de valores de seus alunos. Já sobre a disciplina escolar Biologia, Marandino et al (2009) afirmam que, embora esta possua laços mais estreitos com sua ciência de referência (as Ciências Biológicas) e utilize a Teoria Sintética da Evolução como eixo integrador de seu currículo, esta disciplina vem incorporando ao longo do tempo finalidades definidas por Goodson (1983) como oriundas de tradições acadêmicas, utilitárias e pedagógicas. Ainda sobre a disciplina escolar Biologia, Krasilchik (1988) aponta quatro dimensões para o trabalho de conteúdos biológicos: a ambiental própria do enfoque naturalístico, a médica oriunda do enfoque da biologia aplicada, a cultural e histórica relacionada a aspectos socioculturais, e, por último, a ética e filosófica parte da bioética.

A emergência de um contexto social fortemente influenciado por questões científicas e tecnológicas levou uma série de autores a justificar o desenvolvimento de uma educação em Ciências e Biologia que permita aos seus educandos compreender a natureza das questões que envolvem aspectos científicos, tecnológicos e sociais, bem como a preparação para a tomada de decisões quando confrontados com situações que envolvam aspectos científicos e tecnológicos (CEREZO, 1998; AULER; BAZZO, 2001; SANTOS; MORTIMER, 2002; DELIZOICOV, AULER, 2011).

Em minha própria pesquisa de mestrado procurei olhar para o ensino de Ciências e Biologia como "cruzamento de fronteiras". Com o apoio de Aikenhead et al (2009) e Bourdieu (2004), busquei discutir que a educação científica e biológica como um processo no qual alguns alunos possuem maior ou menor familiaridade. Aprender ciências na escola, para Aikenhead, pode muitas vezes ser entendido como uma aquisição cultural diferente daquela que integra a vivência dos educandos. Já o conceito bourdieuniano de habitus, entendido como uma matriz geradora de disposições, que apesar flexível, tende a se manter estável quando não confrontada com situações inéditas, permite pensar no desenvolvimento de um habitus escolar. Ao entender que a cultura científica não integra a priori o habitus primário de grande parte dos educandos em Ciências e Biologia, e mesmo de muitos licenciandos da área, argumentei que o processo de ensino aprendizagem deve se basear num espaço de confrontos com situações inéditas. Tal processo permitiria a construção de um novo habitus, favorecendo a construção de conhecimento mais complexos e diversificados. 
Diante de tudo que foi exposto até aqui, percebo a educação em Ciências e Biologia como um lugar estratégico de forte interesse ao patrulhamento ideológico neoconservador dentro de cenário de disputas sobre as funções e atribuições educacionais em curso. Nesse sentido, acredito que pensar as possíveis implicações do avanço conservador educacional essa área permite traçar estratégias de enfrentamento calcadas em uma realidade concreta. Longe de tentar extrapolar resultados obtidos sem verificação empírica, entendo que a educação de maneira geral se insere num campo maior de disputas políticas e, portanto, as distintas demandas por educação, currículo e modelos político-pedagógicos carregam diferentes modelos de sociedade e organização econômicas e culturais (ROSA, 2018). Isso vale para à educação em Ciências e Biologia.

Neste contexto, a emergência de grupos e agentes conservadores no espaço público e suas perspectivas de vida em sociedade, família, educação e democracia buscam legislar sobre os objetivos educacionais, formação e atuação docente. O combate à diversidade e o familismo somam-se à privatização da esfera pública e procuram tornar o universo educacional menos plural e mais burocrático, firmemente comprometido com os valores morais, religiosos e militaristas. Acredito que essa intromissão na educação em Ciências e Biologia pode influenciar negativamente os conteúdos de origem e evolução da vida, sexualidade, reprodução humana, genética, compreensão da natureza da Ciência, seus potenciais e limites, entre outros. Estes tópicos do currículo entram em choque com valores cristãos tradicionais e mobilizam afetos e antagonismos em discussões ocorridas tanto nos espaços institucionais, como nas redes sociais e demais espaços da vida em sociedade, conforme já apontado (BORBA et al, 2019).

Tratarei especificamente de dois desses componentes curriculares de maneira sucinta: a evolução biológica e a reprodução/sexualidade humana. A Teoria Sintética da Evolução explica o processo de evolução das espécies ao longo do tempo e funciona como eixo unificador da Biologia moderna. Os desafios relacionados ao ensino de evolução vêm sendo explorados pelos pesquisadores brasileiros ao longo dos últimos anos e conjugam aspectos didático pedagógicos como relacionados aos livros didáticos, concepções e incompreensões de professores e alunos (ALMEIDA, 2012; EL-HANI; SEPÚLVEDA, 2010) e problemas de aceitação do conteúdo por questões religiosas que remetem a pedidos por equiparação entre o conteúdo científico e doutrinas religiosas, como o 
criacionismo (DORVILLÉ; SELLES, 2016). Enquanto nos EUA os conflitos entre evolução e criacionismo têm uma longa história de judicializações, no Brasil as polêmicas e disputas são mais recentes.

Para Selles et al (2016), as implicações da atuação neoconservadoras sobre o ensino de evolução não se limitam às disciplinas escolares Ciência e Biologia. Para a autora e seus colaboradores, o lobby pró ensino religioso confessional obrigatório, além de ferir o princípio da laicidade, funcionaria como um contraponto estratégico aos conteúdos científicos (SELLES et al, 2016). Além disso, pastores e políticos pentecostais têm agido para proibir o ensino da evolução e defendido o ensino obrigatório do criacionismo em escolas públicas e privadas (BRASIL, 2014; MALAFAIA, 2009).

Em um ambiente de antagonismos sociais cultivados por desconfianças doutrinárias promovidas por agentes como o Movimento Escola sem Partido, o ensino de evolução passa a se tornar um campo ainda mais minado o que pode ser tornar uma dificuldade a mais para os professores de Ciências e Biologia, que precisam ser extremamente cuidadosos ao lidar com as crenças dos alunos ou podem ser taxados de doutrinadores, comprometendo a discussão do conhecimento científico em função de disputas pela moralidade hegemônica na sociedade.

Essa preocupação se estende às discussões sobre sexualidade humana no ambiente escolar. Grupos conservadores afirmam que as discussões sobre gênero e sexualidade nos ambientes escolares buscam perverter os valores morais cristãos e confundir os alunos sobre seus corpos. Tal entendimento se assenta no ressentimento destes grupos quanto aos avanços obtidos por coletivos LGBTQI+e feministas nos últimos anos (MIGUEL, 2016). O chamado combate à "Ideologia de Gênero", cunhada pelo Vaticano e propagada por lideranças evangélicas brasileiras se espalhou como pólvora por todos os níveis sociais. É atribuído ao "gênero" status de "técnica marxista internacional" voltada à destruição da família tradicional como instituição (CUNHA, 2017).

A Frente Parlamentar Evangélica do Congresso Nacional brasileiro declara ter o compromisso de "Libertar a educação pública do autoritarismo da ideologia de gênero, da ideologia da pornografia, e devolver às famílias o direito da educação sexual das suas crianças e adolescentes." (FRENTE PARLAMENTAR EVANGÉLICA, 2018, p. 54). As discussões sobre gênero e sexualidade foram 
também importantes motes da campanha eleitoral de 2018, e figuraram como principal plataforma de defesa familista de Jair Bolsonaro.

A despeito das controvérsias recentes, a educação sexual faz parte de documentos curriculares brasileiros desde a década de 1990 (BRASIL, 1998). Cabe à escola informar de maneira crítica e reflexiva sobre a saúde dos seus educandos. A Biologia, ao tratar temas como a reprodução humana, sistema reprodutor, doenças sexualmente transmissíveis e práticas de saúde, tornou-se um dos espaços em que discussões relacionadas à sexualidade tendem a surgir na escola. As discussões realizadas em sala de aula representam a oportunidade de conhecimento sobre si e sobre o outro em seus aspectos sociais, psicológicos e biológicos (SANTOS; SILVA, 2019). Estes direcionamentos, apesar de apontados na literatura educacional como profícuos, encontram a resistência das forças neoconservadoras, que são contra a discussão de temas ligados a sexualidade na escola, compondo o desafio de sua inserção no ensino de Biologia. Utiliza-se, assim, a educação para reforçar uma moralidade conservadora, tradicional e cristã na esfera pública, comprometendo-se a construção de uma educação plural e democrática. A politização das fobias e antagonismos sociais funciona, segundo Ronaldo Almeida (2017), como uma linha de força conservadora socialmente intolerante que frequentemente se une àquela de caráter religioso e moralmente regulador.

Finalizo esta seção com o entendimento de que ainda há muito o que se discutir sobre a privatização familista, intolerante e moralmente religiosa da educação pública, em geral, e, especialmente, da educação em Ciências e Biologia. Por abordar conteúdos de forte interesse e patrulha neoconservadora, as abordagens pedagógicas, a autonomia docente e o direito à aprendizagem política e emancipatória em questões de Ciência e Biologia podem ser prejudicados. É importante levar em consideração a Reforma do Ensino Médio, nesse contexto, ao legar às Ciências Naturais o lugar de apenas mais um itinerário formativo, a pressão sobre a formação de qualidade no período da educação básica comum, o Ensino Fundamental, aumenta consideravelmente.

Ao tentar transformar a educação em um espaço de instrução e aquisição de conteúdo neutros, os grupos neoconservadores se alinham as perspectivas bancárias e burocráticas criticadas por Paulo Freire. Não sem motivo o educador passa a ser tão combativo. De maneira geral, a atuação neoconservadora sobre à Educação em Ciências e Biologia tanto se opõe ao conhecimento científico, quando 
este se distancia de visões religiosas, quanto exige o status de equivalência científica para reforçar a inclusão de seus valores, preconceitos e doutrinas no currículo escolar (SELLES et al, 2016). Dessa maneira, compromete a construção de uma educação democrática e estimula a reprodução de desigualdades e discriminações profundamente presentes na sociedade brasileira, seja limitando o acesso ao conhecimento científico, seja reforçando a estigmatização de minorias.

Expostos os principais elementos daquilo que pretendo aprofundar ao fim desta investigação, reitero efeitos de conclusão de que a retórica neoconservadora aplicada à educação identificada nesta investigação se apoia numa perspectiva autoritária, tecnicista, moralizante e não laica. A autoridade familiar é defendida como antídoto às práticas doutrinadoras orquestradas por professores em ambientes escolares nas diferentes disciplinas. A ânsia por ordem (quase sempre de inspiração militar), formação em valores morais (cristãos) e disputas em torno do conceito de laicidade e liberdade religiosa integram esse quadro.

A partir destes resultados encontrados, é possível observar as diferentes funções atribuídas ao processo de escolarização e seus sujeitos. Em última instância disputam-se os sentidos de educação e sociedade. Entendo que ainda há muito a ser feito em discussões desta natureza. As discussões relacionadas à educação científica e biológica, apontadas como um desdobramento futuro possível evidenciam essa realidade. Finalizo esta tese, no entanto, com o firme entendimento de que as reflexões atuais (e futuras) representam significativas contribuições para as discussões relacionadas à atuação neoconservadora sobre as políticas públicas educacionais, os currículos e sua influência sobre o cotidiano escolar. Um projeto de educação nacional que se pretenda emancipatório não pode, e não deve, fugir deste debate. 


\section{Referências}

ABRANCHES, S. Polarização radicalizada. In: ABRANCHES, S; ALMEIDA, R de. Democracia em risco? 22 ensaios sobre o brasil hoje. São Paulo: Companhia das Letras, 2019.

ADRIÃO, T. Dimensões e Formas da Privatização da Educação no Brasil: caracterização a partir de mapeamento de produções nacionais e internacionais. Currículo sem Fronteiras, v. 18, n. 1, p. 8-28, 2018.

AIKENHEAD, G.; LIMA, K. Science, culture and citizenship: Cross-cultural science education. Revista Brasileira de Pesquisa em Educação em Ciências, v. 9, n. 3, 2009.

AKKARI, A. Intercultural education in Brazil: between conservatism and radical transformations. Prospects, [S.L.], v. 42, n. 2, p. 161-175, jun. 2012. Springer Science and Business Media LLC. http://dx.doi.org/10.1007/s11125-012-9228-8. ALBUQUERQUE, J. EDUCAÇÃO E DEMOCRACIA E ESCOLA EM TEMPOS SOMBRIOS: neoconservadorismo na educação brasileira. 2019. 110 f. Dissertação (Mestrado) - Curso de Educação, Fundação Universidade de Passo Fundo, Passo Fundo, 2019.

ALMEIDA, K. Não se abre à força um botão de rosa, e sobretudo, com as mãos sujas: agruras da educação sexual no ambiente escolar e os desafios atuais frente à ideologia de gênero. 2018. 150 f. Tese (Doutorado em Tecnologia e Sociedade) - Universidade Tecnológica Federal do Paraná, Curitiba, 2018. Disponível em: http://repositorio.utfpr.edu.br/jspui/handle/1/3808 Acesso: $11 / 05 / 2021$.

ALMEIDA, R.. A onda quebrada - evangélicos e conservadorismo. Cadernos Pagu, n. 50, 2017.

DEUSES DO PARLAMENTO: OS IMPEDIMENTOS DE DILMA. In: ALMEIDA, R; TONIOL, R. CONSERVADORISMOS, FASCISMOS E FUNDAMENTALISMOS. Campinas, São Paulo: Editora da Unicamp, 2018. Epub.

Deus acima de tudo. In: ABRANCHES, S; ALMEIDA, R de. Democracia em risco? 22 ensaios sobre o brasil hoje. São Paulo: Companhia das Letras, 2019. ALVES, E. Concepções de finalidades educativas escolares na perspectiva de líderes religiosos evangélicos neopentecostais. 2020. 146 f. Dissertação 
(Programa de Pós-Graduação STRICTO SENSU em Educação) - Pontifícia Universidade Católica de Goiás, Goiânia.

ALVES, R. O que é religião?. São Paulo: Edições Loyola, 2014.

ANDERY, A.M.; MICHELETTO, N.; SÉRIO, T.M.P; RUBANO, D.R.; MOROZ, M.; PEREIRA, M.E; GIOIA, S.C.; GIANFALDONI, M.; SAVIOLI, M.R; ZANOTTO, M.L. Para compreender a Ciência numa perspectiva histórica. Rio de Janeiro: Giramond, 2014.

ANTUNES, C. SUBSECRETARIA DE FOMENTO ÀS ESCOLAS CÍVICOMILITARES - SECIM/SEB/MEC - Cidadania: Educação em valores!

Disponível em: $<$ https://www2.camara.leg.br/atividade-

legislativa/comissoes/comissoes-

permanentes/ce/noticias/CRISTIANEANTUNESSECIMSEBMEC090519.ppt>. Acesso em: 11 nov. 2019.

APPLE, M. "Endireitar" a educação: as escolas e a nova aliança conservadora. Currículo sem fronteiras, v. 2, n. 1, p. 55-78, 2002.

Educando à Direita: mercados, padrões, deus e desigualdade. São Paulo: Cortez, 2003. TRADUÇÃO: INSTITUTO PAULO FREIRE.

Doing the work of God: Home schooling and gendered labor. In: APPLE, M. W.; BALL, S. J.; GANDIN, L. A. (Eds.). The Routledge international handbook of the sociology of education. New York: Routledge, 2010. p. 145154.

ARAGUSUKU, H; LOPES, M. Políticas públicas e cidadania LGBT em Mato Grosso: Uma década de avanços e retrocessos (2007-2017). Sexualidad, Salud y Sociedad (Rio de Janeiro) [online]. 2018, n. 29 [Acessado 30 Maio 2021] , pp. 147171. Disponível em: <https://doi.org/10.1590/1984-6487.sess.2018.29.07.a〉. Epub May-Aug 2018. ISSN 1984-6487. $\quad$ https://doi.org/10.1590/19846487.sess.2018.29.07.a.

ARGUELLO, K. Do Estado social ao Estado penal: invertendo o discurso da ordem. In: CONGRESSO PARANAENSE DE CRIMINOLOGIA. 2005. p. 01 28.

AULER, D; BAZZO, W. Reflexões para a Implementação do Movimento CTS no Contexto Educacional Brasileiro - Revista Ciência e Educação, v.7, n.1, p.1-13, 2001 . 
AUNE, K.; GUEST, M. Christian University Students' Attitudes to Gender: constructing everyday theologies in a post-feminist climate. Religions, [S.L.], v. 10, n. 2, p. 133, 23 fev. 2019. MDPI AG. http://dx.doi.org/10.3390/rel10020133. AVELAR, M. O público, o privado e a despolitização nas políticas educacionais. In: CÁSSIO, F. (Ed.). Educação contra a barbárie: por escolas democráticas e pela liberdade de ensinar. 1. ed. São Paulo: Boitempo, 2019. p. 73-79.

Goiás, Goiânia, 2019. Disponível em: tede2.pucgoias.edu.br:8080/handle/tede/4458. Acesso em: 11 maio 2021.

.; BALL, S. J. Mapping new philanthropy and the heterarchical state: The Mobilization for the National Learning Standards in Brazil. International Journal of Educational Development, v. 64, p. 65-73, jan. 2019.

AVELAR, S. Formação profissional, fundamentos do serviço social e ofensiva conservadora na educação superior: : a expansão dos cursos de serviço social no estado de goiás. 2019. 130 f. Dissertação (Mestrado) - Curso de Serviço Social, Programa de Pós-Graduação Stricto Sensu em Serviço Social, Pontifícia Universidade Católica de

BAGLEY, C.; BEACH, D. The marginalisation of social justice as a form of knowledge in teacher education in England. Policy Futures In Education, [S.L.], v. $13, \quad$ n. $4, \quad$ p. 424-438, 24 fev. 2015. SAGE Publications. http://dx.doi.org/10.1177/1478210315571220.

BARDIN. L. Análise de conteúdo. Lisboa: Editora Edições 70, 2016.

BENCZE, J. Exposing and deposing hyper-economized school science. Cultural Studies Of Science Education, [S.L.], v. 5, n. 2, p. 293-303, 11 mar. 2010. Springer Science and Business Media LLC. http://dx.doi.org/10.1007/s11422-010-9256-8.

L; CARTER, L. Globalizing students acting for the common good. Journal Of Research In Science Teaching, [S.L.], v. 48, n. 6, p. 648-669, 25 maio 2011. Wiley. http://dx.doi.org/10.1002/tea.20419.

BERGER, P. O dossel sagrado: elementos para uma teoria sociológica da religião. 1985.

A dessecularização do mundo: uma visão global. Religião e Sociedade, v. 21, n. 1, p. 9-24, 2001. 
BEZERRA NETO, L.; SANTOS, F. R. Neoconservadorismo, movimentos sociais e educação no campo no Brasil. Crítica Educativa, v. 2, n. 1, p. 52-65, Sorocaba, 2016. DOI: http://dx.doi.org/10.22476/revcted.v2i1.77

BOBBIO, N. Democracia y sistema internacional. Revista Internacional de Filosofía Política (4), 1994, p. 5-21. ISSN 1132-9432

BOECKEL, C.; ÁVILA, E.; RODRIGUES, M. Deputados entram sem avisar no Colégio Pedro II, anunciam "vistoria" e provocam confusão. Disponível em: $<$ https://g1.globo.com/rj/rio-de-janeiro/blog/edimilsonavila/noticia/2019/10/11/deputados-tentam-fazer-vistoria-no-colegio-pedro-ii-eprovocam-confusao-com-reitoria.ghtml>. Acesso em: 13 dez. 2019.

BORBA, R.C; ANDRADE, M. C. P. de; SELLES, S. E. Ensino de ciências e biologia e o cenário de restauração conservadora no Brasil: inquietações e refl: inquietações e reflexões. Revista Interinstitucional Artes de Educar, [S.L.], v. 5, n. 2, p. 144-162, 29 ago. 2019. Disponível em: https://www.researchgate.net/publication/335478624_Ensino_de_ciencias_e_biol ogia_e_o_cenario_de_rest. Acesso em: 15 nov. 2020.

BOURDIEU, P. Estrutura, habitus e prática. Economia das trocas simbólicas, v. 5, p. 337-361, 2004

BRANDÃO, C. R. Ser católico: dimensões brasileiras - um estudo sobre a atribuição de identidade através da religião. In: SACHS, V. et al. Brasil e EUA: religião e identidade nacional. Rio de Janeiro: Graal, 1988. p.27-58.

BRASIL. Lei de Diretrizes e Bases da Educação. Lei 9.394, de 20 de dezembro de 1996.

Lei 10.639, de 9 de janeiro de 2003. Altera a Lei no 9.394, de 20 de dezembro de 1996, que estabelece as diretrizes e bases da educação nacional, para incluir no currículo oficial da Rede de Ensino a obrigatoriedade da temática "História e Cultura Afro-Brasileira", e dá outras providências. Disponível em: http://www.planalto.gov.br/ccivil_03/leis/2003/110.639.htm. Acesso em $11 / 04 / 2020$.

Decreto 8.727, de 28 de abril de 2016. Dispõe sobre o uso do nome social e o reconhecimento da identidade de gênero de pessoas travestis e transexuais no âmbito da administração pública federal direta, autárquica e fundacional. Disponível em: http://www.planalto.gov.br/ccivil_03/_Ato20152018/2016/Decreto/D8727.htm Acesso em 11/04/2020. 
BROWN, W. Nas ruínas do neoliberalismo: A ascensão da política antidemocrática no Ocidente. São Paulo: Politeia, 2019.

BURITY, J. A onda conservadora na política brasileira traz o fundamentalismo ao poder? In: ALMEIDA, R.; TONIOL, R. Conservadorismos, fascismos e fundamentalismos: análises conjunturais. Editora Unicamp, 2018. Pág. 15 - 68. CACHAPUZ, A. PAIXÃO, F; LOPES, J. B; GUERRA, C. Do estado da arte da pesquisa em educação em ciências: linhas de pesquisa e o caso "ciência-tecnologiasociedade." Alexandria - Revista de Educação em Ciência e Tecnologia. Florianópolis, v. 1, n. 1, p. 27-49, 2008.

CALDEIRA, H. Evolution : A Journal of Nature [manuscrito] : ciência, evolução e fundamentalismo nos Estados Unidos (1927- 1938). 2018. 137 f. Dissertação (Mestrado) - Curso de Filosofia, Faculdade de Filosofia e Ciências Humanas, Universidade Federal de Minas Gerais, Belo Horizonte, 2018. Disponível em: https://repositorio.ufmg.br/bitstream/1843/BUOSBALFC5/1/disserta_o__henri que_caldeira_com_ficha_e_aprova_o.pdf. Acesso em: 11 maio 2021.

CAMARGO, S. “CADA UM BRINCA COM O QUE QUISER! ISSO AÍ É RACHISMO!": INFÂNCIA E RELAÇÕES DE GÊNERO NA BRINQUEDOTECA DE UMA INSTITUIÇÃO DE EDUCAÇÃO INFANTIL. 2019. 175 f. Dissertação (Mestrado) - Curso de Educação, Universidade Federal de Mato Grosso, Cuiabá, 2019.

CAMPOS, R. Programa Criança Feliz: um salto histórico para o passado. Praxis Educativa, [S.L.], v. 15, p. 1-22, 2020. Universidade Estadual de Ponta Grossa (UEPG). http://dx.doi.org/10.5212/praxeduc.v.15.15445.087.

CARA, D. O programa "Escola sem Partido" quer uma escola sem educação In: Ação Educativa Assessoria, Pesquisa e Informação (Org): A ideologia do movimento escola sem partido: 20 autores desmontam o discurso. São Paulo: Ação Educativa, 2016, p. 43 - 48. . Contra a barbárie, o direito à educação. In: CÁSSIO, F. (Ed.). Educação contra a barbárie: por escolas democráticas e pela liberdade de ensinar. 1. ed. São Paulo: Boitempo, 2019. p. 25-31.

CARDOSO, J.; MWOLO, M. Assessment of non-formal sexual education strategies for adolescent girls: the case of tanzania. Ensaio: Avaliação e Políticas 
Públicas em Educação, [S.L.], v. 25, n. 95, p. 527-547, 27 abr. 2017. FapUNIFESP (SciELO). http://dx.doi.org/10.1590/s0104-40362017002501111.

CARNOY, M.; MCEWAN, P. Does privatization improve education? The case of Chile's national voucher plan. In: PLANK, D.; SYKES, G. (Eds.). . Choosing choice: School choice in international perspective. New York: Teachers' College Press, Columbia University, 2003. p. 24-44.

CARVALHO, J. Estética da Experiência de Educar Contra o Conservadorismo. Curriculo Sem Fronteiras, v. 19, n. 3, p. 1039-1058, 31 dez. 2019. Curriculo sem Fronteiras. http://dx.doi.org/10.35786/1645-1384.v19.n3.14 CARVALHO, M C.; SÍVORI, H F. Ensino religioso, gênero e sexualidade na política educacional brasileira. Cadernos Pagu [online]. 2017, n. 50 [Acessado 30 Maio 2021] ， e175017. Disponível em: <https://doi.org/10.1590/18094449201700500017>. Epub 18 Dez 2017. ISSN 1809-4449. https://doi.org/10.1590/18094449201700500017.

CASAnOVA, J. Public Religions in the Modern World. Chicago, Chicago University Press, 1994.

CAVAZOS-REHG, P. et al. Associations Between Sexuality Education in Schools and Adolescent Birthrates. Archives Of Pediatrics \& Adolescent Medicine, [S.L.], v. 166, n. 2, p. 134, 1 fev. 2012. American Medical Association (AMA). http://dx.doi.org/10.1001/archpediatrics.2011.657

CECCHETTI, E; TEDESCO, A. Educação Básica em "xeque": homeschooling e fundamentalismo religioso em tempos de neoconservadorismo. Praxis Educativa, [S.L.], v. 15, p. 1-17, 2020. Universidade Estadual de Ponta Grossa (UEPG). http://dx.doi.org/10.5212/praxeduc.v.15.14816.026.

CEREZO, J. A. L. Ciência, Tecnologia y Sociedad: el estado de la cuestión en Europa y Estados Unidos. In: revista Iberoamericana de Educación, nº18, p.125, 1998.

CHALMERS, A. F. A Fabricação da ciência. São Paulo: Editora da Universidade Estadual Paulista, 1994.

CHAU, K.; SECK, A.; CHANDRA-MOULI, V.; SVANEMYR, J. Scaling up sexuality education in Senegal: integrating family life education into the national curriculum. Sex Education, [S.L.], v. 16, n. 5, p. 503-519, 6 jan. 2016. Informa UK Limited. http://dx.doi.org/10.1080/14681811.2015.1123148. 
CLARKE, M. The (absent) politics of neo-liberal education policy. Critical Studies In Education, [S.L.], v. 53, n. 3, p. 297-310, out. 2012. Informa UK Limited. http://dx.doi.org/10.1080/17508487.2012.703139

COELHO, F. "MENINO JÁ NASCE MENINO, MENINA JÁ NASCE MENINA": Fobia religiosa de gênero e suas implicações no debate sobre o Plano Nacional de Educação brasileiro no período 2012-2014. 2017. 130folhas. Dissertação (Ciências da Religião) - Universidade Metodista de São Paulo, São Bernardo do Campo.

CORTI, A. P. Ensino médio: entre a deriva e o naufrágio. In: CÁSSIO, F. (Ed.). Educação contra a barbárie: por escolas democráticas e pela liberdade de ensinar. 1. ed. São Paulo: Boitempo, 2019. p. 47-52.

COUTINHO, R.; MIRANDA-RIBEIRO, P. Religião, religiosidade e iniciação sexual na adolescência e juventude: lições de uma revisão bibliográfica sistemática de mais de meio século de pesquisas. Revista Brasileira de Estudos de População [online]. 2014, v. 31, n. 2 [Acessado 30 Maio 2021], pp. 333-365. Disponível em: <https://doi.org/10.1590/S0102-30982014000200006>. Epub 23 Jan 2015. ISSN 1980-5519. https://doi.org/10.1590/S0102-30982014000200006.

CROWTHER, L. Conservadorismo. In: OUTHWAITE, W.; BOTTOMORE, T. (Ed.). Dicionário do pensamento social do século XX. Rio de Janeiro: Jorge Zahar, p. 132-133, 1996.

CURY, C. R. J. Homeschooling ou educação no lar. Educação em Revista, v. 35, 2019.

CUNHA, C. V; LOPES, P; LUI, J. RELIGIÃO E POLÍTICA: medos sociais, extremismo religioso e as eleições 2014. Rio de Janeiro: Fundação Heinrich Böll: Instituto de Estudos da Religião, 2017. 196 p.

CUNHA, L. A. Sintonia oscilante: religião, moral e civismo no Brasil1931/1997. Cadernos de Pesquisa, v. 37, n. 131, p. 285-302, 2007.

A laicidade em disputa: religião, moral e civismo na educação brasileira. Revista Teias, v. 15, n. 36, p. 21, 2014.

O projeto reacionário de educação. Produção Digital Independente (Homepage), 2016a.

A entronização do ensino religioso na Base Nacional Comum Curricular.

Educação \& Sociedade [online]. 2016b, v. 37, n. 134, pp. 266-284. Disponível em: 
<https://doi.org/10.1590/ES0101-73302016158352>.

ISSN

$1678-4626$.

https://doi.org/10.1590/ES0101-73302016158352.

CUNHA, L F B. O discurso homofóbico nas redes sociais e o confronto ideológico acerca da diversidade sexual no Brasil. 2019. 79 f. Dissertação (Mestrado em Letras) - Universidade Federal do Amazonas, UFAM, 2019. Disponível em: https://tede.ufam.edu.br/handle/tede/7648 Acesso:11/05/2021

CUNHA, M N. "É preciso salvar a família": gênero, religião e política no contexto do neoconservadorismo evangélico nas mídias no brasil. In: CUNHA, Christina Vital da; LOPES, Paulo Victor Leite; LUI, Janayna. RELIGIÃO E POLÍTICA: medos sociais, extremismo religioso e as eleições 2014. Rio de Janeiro: Fundação Heinrich Böll: Instituto de Estudos da Religião, 2017. p. 157-169.

DANIELSEN, D.; BRUSELIUS-JENSEN, M.; LAITSCH, D. Reconceiving barriers for democratic health education in Danish schools: an analysis of institutional rationales. Asia-Pacific Journal Of Health, Sport And Physical

Education, [S.L.], v. 8, n. 1, p. 81-96, 2 jan. 2017. Informa UK Limited. http://dx.doi.org/10.1080/18377122.2016.1277546.

DELIZOICOV, D; AULER, D. Ciência, Tecnologia e Formação Social do Espaço: questões sobre a não-neutralidade. Alexandria: Revista de Educação em Ciência e Tecnologia, v. 4, n. 2, p. 247-273, 2011.

DENZIN, N. K.; LINCOLN, Y. S. O planejamento da pesquisa qualitativa: teorias e abordagens. In: $\mathbf{O}$ planejamento da pesquisa qualitativa: teorias e abordagens. 2006. p. 432-432.

DIAS, T B. SOBRE RELIGIÃO, ESTADO LAICO E CIDADANIA LGBT+: A FRENTE PARLAMENTAR EVANGÉLICA E A DEFESA DA VERDADE SOBRE A FAMíLIA. 2017. 151 folhas. Dissertação (Ciências da Religião) Universidade Metodista de São Paulo, São Bernardo do Campo. Disponível em: http://tede.metodista.br/jspui/handle/tede/1647 Acesso: 11/05/2021

DOHERTY, C.; LUKE, A.; SHIELD, P.; HINCKSMAN, C. Choosing your niche: the social ecology of the international baccalaureate diploma in australia. International Studies In Sociology Of Education, [S.L.], v. 22, n. 4, p. 311-332, dez. $2012 . \quad$ Informa UK Limited. http://dx.doi.org/10.1080/09620214.2012.745346.

DORVILLÉ, L F M; TEIXEIRA, P. Ensino de Ciências e Biologia e a NECESSIDADE DE UMA ÉTICA CORDIAL: ENSINO DE EVOLUÇÃO, 
CRENÇAS RELIGIOSAS E ESTRATÉGIAS EMPÁTICAS. In: TEIXEIRA, Pedro Pinheiro; DALMO, Roberto. CONTEÚDOS CORDIAIS: biologia humanizada para uma escola sem mordaça. São Paulo: Editora Livraria da Física, 2019. Cap. 1. p. 1-16.

; SOARES, C. Entre dogmatismos e silenciamentos: o ensino de evolução e as ideias religiosas. In: ANDRADE, Marcelo. Diferenças Silenciadas: pesquisas em educação, preconceito e discriminação. Rio de Janeiro: 7Letras, 2015. p. $70-87$.

ESCOLA CÍVICA BRASILEIRA. Pelotão da R.O.E (Ronda Ostensiva Escolar) e Escola Cívica Brasileira na posse do nosso Presidente Jair Messias Bolsonaro no dia 01/01/2019. Disponível em: <https://www.facebook.com/EscolaCivicaBrasileira/posts/846006232457969>. Acesso em: 21 nov. 2019.

ECKLUND, E.; SCHEITLE, C P.; PEIFER, J.; BOLGER, D. Examining Links

Between Religion, Evolution Views, and Climate Change Skepticism. Environment And Behavior, [S.L.], v. 49, n. 9, p. 985-1006, 26 out. 2016. SAGE Publications. http://dx.doi.org/10.1177/0013916516674246.

EDITORES DA REVISTA EDUCAÇÃO \& SOCIEDADE. NEOCONSERVADORISMO, EDUCAÇÃO E PRIVAÇÃO DE DIREITOS. Educação \& Sociedade [online]. 2017, v. 38, n. 141 [Acessado 30 Maio 2021] , pp. 865-872. Disponível em: <https://doi.org/10.1590/ES010173302017v38n141ED>. ISSN 1678-4626. https://doi.org/10.1590/ES010173302017v38n141ED.

FAGUNDEZ, I. Mesmo sem lei, Escola sem Partido se espalha pelo país e já afeta rotina nas salas de aula.

FELICÍSSIMO, M. $\operatorname{Re}(\mathbf{a})$ presentações da homofobia e da homossexualidade: um estudo discursivo a partir de vídeos do kit "escola sem homofobia". 2014. 302 f. Tese (Doutorado) - Curso de Educação, Universidade Federal de Minas Gerais, Belo Horizonte, 2014. Disponível em: https://repositorio.ufmg.br/handle/1843/MGSS-9LZPAY. Acesso em: 11 maio 2021.

FERREIRA, A. R. Escolas cívico-militares: expansão de modelo divide opiniões. Disponível em: <https://novaescola.org.br/conteudo/15991/escolas- 
civico-militares-expansao-de-modelo-divide-opinioes>. Acesso em: 21 nov. 2019a.

FERREIRA, P. Especialistas em educação criticam projeto de escolas cívicomilitares lançado pelo governo. O Globo, 5 set. 2019b.

FRENTE PARLAMENTAR EVANGÉLICA. Manifesto à Nação. Brasília: Câmara dos Deputados, 2018. Disponível em: https://static.poder360.com.br/2018/10/Manifesto-a-Nacao-frente-evangelicaoutubro2018.pdf

FREIRE, L. Retomando a consciência: reações conservadoras a partir do debate sobre família e gênero. 2018. 140 f. Dissertação (Mestrado) - Curso de Ciências Sociais, Universidade Estadual do Oeste do Paraná, Toledo, 2018. Disponível em: http://tede.unioeste.br/handle/tede/4122. Acesso em: 11 maio 2021. FREIRE, P. Pedagogia do Oprimido. 6. ed. Rio de Janeiro: Paz e Terra, 1978.

G1 SC. Deputada estadual do PSL eleita por SC incita alunos a filmar e denunciar professores. Disponível em: <https://g1.globo.com/sc/santacatarina/eleicoes/2018/noticia/2018/10/29/deputada-estadual-do-psl-eleita-por-scincita-alunos-a-filmar-e-denunciar-professores.ghtml>. Acesso em: 13 dez. 2019. GEERTZ, C. A Interpretação das Culturas. Rio de Janeiro: LTC, 1989. O beliscão do destino: a religião como experiência, sentido, identidade e poder. In: Nova luz sobre a antropologia. Rio de Janeiro: Jorge Zahar Editor, 2001. p. 140-165.

GIROUX, H. Os professores como intelectuais: rumo a uma pedagogia crítica da aprendizagem. Porto Alegre: Artes Médicas, 1997.

The university in chains: Confronting the military-industrial-academic complex. Boulder, CO: Paradigm Publishers, 2012.

GOMES, J. Democracia e a educação escolar: uma análise à luz da pedagogia histórico-crítica. 2018. 123 f. Dissertação (Mestrado) - Curso de Educação, Programa de Pós-Graduação em Educação, Universidade Federal do Espírito Santo, Vitória, 2018. Disponível em: http://repositorio.ufes.br/handle/10/10628. Acesso em: 11 maio 2021.

GOMES, R. Análise e interpretação de dados de pesquisas qualitativas. ORG: MINAYO, M. Pesquisa social: teoria, método e criatividade. Petrópolis, RJ: Vozes, 2007. 
GONZALEZ, J; COSTA, M. Neoliberalismo, neoconservadorismo e educação: movimento escola sem partido para além do projeto de lei. Quaestio - Revista de Estudos em Educação, [s. l], v. 20, n. 3, p. 551-555, dez. 2018. Disponível em: http://periodicos.uniso.br/ojs/index.php/quaestio/article/view/3248. Acesso em: 15 nov. 2020.

GRECCO, C. Crenças sobre sexualidade entre estudantes de Medicina de uma Universidade Federal do sul do Brasil. 2018. 53 f. Dissertação (Mestrado) - Curso de Medicina, Universidade Federal do Rio Grande do Sul. Faculdade de Medicina, Porto Alegre, 2018. Disponível em: http://hdl.handle.net/10183/199086. Acesso em: 11 maio 2021.

HARVEY, D. Breve histórial del liberalismo. AKAL, 2007.

HOFFLINGER, A.; VON HIPPEL, P. T. Does Achievement Rise Fastest with School Choice, School Resources, or Family Resources? Chile from 2002 to 2013. Sociology of Education, v. 93, n. 2, p. 132-152, 22 abr. 2020.

HONORATO, Rafael. GÊNERO NAS POLÍTICAS EDUCACIONAIS DA EDUCAÇÃO DE JOVENS E ADULTOS: TRAJETÓRIA, INFLUÊNCIAS E TEXTOS. 2018. 130 f. Dissertação (Mestrado) - Curso de Educação, Universidade Federal da Paraíba, João Pessoa, 2018.

IBGE. Censo Demográfico. Características gerais da população, religião e pessoas com deficiência. Rio de Janeiro: Instituto Brasileiro de Geografia e Estatística, 2010.

JACÓ, D. Laicidade, sexualidade e conservadorismo morais: uma análise de discursos parlamentares sobre o caso escola sem homofobia de 2010 a 2014. 2019. 145 f. Dissertação (Mestrado) - Curso de Ciência Política, Universidade de Brasília, Brasília, $2019 . \quad$ Disponível em: https://repositorio.unb.br/bitstream/10482/37791/1/2019_DanielOliveiraJac\%c3\% b3.pdf. Acesso em: 15 nov. 2020.

JONES, K. Conservatism and educational crisis: the case of england. Education Inquiry, [S.L.], v. 5, n. 1, p. 24046, jan. 2014. Informa UK Limited. http://dx.doi.org/10.3402/edui.v5.24046.

JOPLING, M. How neoliberal policy inhibits partnership-building in the primary phase: a new social movements approach. Power And Education, [S.L.], v. 11, n. 3, p. 252-267, 25 jan. 2019. SAGE Publications. http://dx.doi.org/10.1177/1757743818823788. 
KAHN, P. «Sauver les lettres», sauver l'école: une défense «de gauche» de 1?enseignement traditionnel?. Revista Lusófona de Educação, [S.L.], n. 43, p. 225-233, 1 mar. 2019. Universidade Lusofona de Humanidades e Tecnologias. http://dx.doi.org/10.24140/issn.1645-7250.rle43.15.

KELLER, D; KELLER, J. G. Politics and Transformation: critical approaches toward political aspects of education. Policy Futures In Education, [S.L.], v. 12, n. $3, \quad$ p. $359-369, \quad 1$ jan. 2014. SAGE Publications. http://dx.doi.org/10.2304/pfie.2014.12.3.359.

KIDDER, J L.; BINDER, A. Trumpism on College Campuses. Qualitative Sociology, [S.L.], v. 43, n. 2, p. 145-163, 1 fev. 2020. Springer Science and Business Media LLC. http://dx.doi.org/10.1007/s11133-020-09446-Z.

KIRK, R. A Política da Prudência. Delaware: Books, 1993.

KOHAN, W. Paulo Freire, mais do que nunca: uma biografia filosófica. 1. ed. Belo Horizonte: Vestígio, 2019.

KOROLCZUK, E; GRAFF, A. Gender as "Ebola from Brussels": the anticolonial frame and the rise of illiberal populism. Signs: Journal of Women in Culture and Society, [S.L.], v. 43, n. 4, p. 797-821, jun. 2018. University of Chicago Press. http://dx.doi.org/10.1086/696691.

KRASILCHIK, M. Ensino de ciências e a formação do cidadão. Em aberto, n. 40, p. 55-60, 1988.

KÜÇÜKER, E. Reasons for Dropouts of Girls from the Formal Secondary Education Living in Rural Areas. Ted Egitim Ve Bilim, [S.L.], p. 1-30, 13 jul. 2018. Turkish Education Association. http://dx.doi.org/10.15390/eb.2018.7537.

LACERDA, M.B. Neoconservadorismo: articulação pró-família, punitivista e neoliberal na Câmara dos Deputados. 2018. 250 f. Tese (Doutorado) - Curso de Ciência Política, Universidade do Estado Rio de Janeiro, Rio de Janeiro, 2018. O novo conservadorismo brasileiro: de Reagan a Bolsonaro. 1. ed. Porto Alegre: Zouk, 2019.

LACEY, H. Valores e atividade científica. São Paulo, Discurso Editorial, 1998. LADD, H. F. Introduction. In: PLANK, D. N.; SYKES, G. (Eds.). . Choosing choice: school choice in international perspective. New York: Teachers' College Press, Columbia University, 2003. p. 1-24. 
LAKSANA, B K. C.; WOOD, B. Navigating religious diversity: exploring young people?s lived religious citizenship in indonesia. Journal Of Youth Studies, Uk, v. 22, n. 6, p. 807-823, 15 nov. 2018. Informa UK Limited. http://dx.doi.org/10.1080/13676261.2018.1545998.

LANDINI, T. S. O professor diante da violência sexual. - São Paulo: Cortez. (Coleção educação e saúde; v.4), 2011.

LEME, R. Movimento estudantil secundarista como resistência às políticas educacionais neoconservadoras: as ocupações de escolas públicas nos estados de São Paulo, Goiás e Paraná (2015-2016). 2018. 239 f. Dissertação (Mestrado) Curso de Educação, Universidade Estadual de Londrina, Londrina, 2018. Disponível em: http://www.bibliotecadigital.uel.br/document/?view=vtls000223922. Acesso em: 11 maio 2021.

LEVITSKY, S.; ZIBLATT, D. Como as democracias morrem. Rio de Janeiro: Zahar, 2018.

LEWONTIN, R. C. Biologia como ideologia: a doutrina do DNA. Ribeirão Preto: FUNPEC, 2000.

LIMA, I. G.; HYPOLITO, M. A. A expansão do neoconservadorismo na educação brasileira. Educação e Pesquisa, São Paulo, V.45, 2019.

LIMA, P. O Projeto Educativo Da Nova Direita Brasileira: sujeitos, pautas e propostas. 2020. 232 f. Dissertação (Mestrado) - Curso de Educação, Programa de Pós-Graduação em Educação, Universidade Federal do Rio Grande do Sul, Porto Alegre, 2020. Disponível em: hdl.handle.net/10183/218427. Acesso em: 11 maio 2021.

LIRA, L. Os atravessamentos ideológicos do movimento escola sem partido. 128 f. Dissertação (Mestrado) - Curso de Linguística Aplicada, Universidade de Taubaté, Taubaté, 2018. Disponível em: http://repositorio.unitau.br/jspui/handle/20.500.11874/947. Acesso: 11 maio 2021. LOUZANO, P; MORICONI, G. Uma guinada equivocada na agenda da educação. In: ABRANCHES, S; ALMEIDA, R de. Democracia em risco? 22 ensaios sobre o brasil hoje. São Paulo: Companhia das Letras, 2019.

LUNA, N. A criminalização da "ideologia de gênero": uma análise do debate sobre diversidade sexual na Câmara dos Deputados em 2015. Cadernos Pagu [online]. 2017, n. 50 [Acessado 30 Maio 2021], e175018. Disponível em: 
<https://doi.org/10.1590/18094449201700500018>. Epub 18 Dez 2017. ISSN 1809-4449. https://doi.org/10.1590/18094449201700500018.

MACHADO, M. D. C. Política e religião: a participação dos evangélicos nas eleições. FGV Editora, 2006.

. "Religião, Cultura e Política". Religião e Sociedade,n.2, pp. 29-56, 2012 MARAFON, G.; SOUZA, M. C. Como o discurso da ideologia de gênero ameaça o caráter democrático e plural da escola. In: PENNA, F.; QUEIROZ, F.; FRIGOTTO, G. (Org). Educação Democrática: Antídoto ao Escola Sem Partido. Rio de Janeiro: UERJ, LPP, 2018. Pág. 75-88.

MACHADO, L.; SELLES, S. E. Reprodução Humana e Sexualidade em Livros Didáticos de Biologia: Tradições Curriculares em Xeque. Anais do VII Encontro Nacional de Ensino de Biologia - ENEBIO. Belém: 2018. p. 1821-1830 MARANDINO, M. SELLES, S.E.; FERREIRA, M.S. Ensino de Biologia: histórias e práticas em diferentes espaços educativos. São Paulo: Cortez, 2009. P. 215

MARIANO, R. Neopentecostais: sociologia do novo pentecostalismo no Brasil. Edições Loyola, 1999.

. Laicidade à brasileira: Católicos, pentecostais e laicos em disputa na esfera pública. Civitas, v. 11, n. 2, p. 238-258. Porto Alegre, mai/ago, 2011.

Expansão e ativismo político de grupos evangélicos conservadores: Secularização e pluralismo em debate. Civitas, v. 16, n. 4, p. 710-728, Porto Alegre, out/dez. 2016.

MATARAZZO, R.; GONÇALVES, G. Saiba como o termo "ideologia de gênero" surgiu e é debatido. Disponível em: <https://g1.globo.com/sp/saopaulo/noticia/2019/09/03/saiba-como-o-termo-ideologia-de-genero-surgiu-e-edebatido.ghtml>. Acesso em: 13 dez. 2019.

MATOS, M.; LIMA, I.; RIOS, N.; MACIEL, C. Ensino de Biologia e políticas públicas conservadoras: possibilidades de reflexão e resistência na formação continuada de professores. Revista da SBEnBio, v.9: p. 3096-3108, 2016.

MATEJU, P.; SMITH, Ml L.; WEIDNEROVÁ, S.; ANÝžOVÁ, P. The role of basic values and education on women's work and family preferences in Europe. International Journal Of Sociology And Social Policy, [S.L.], v. 37, n. 9/10, p. 494-514, 12 set. 2017. Emerald. http://dx.doi.org/10.1108/ijssp-10-20160117. 
MAYER, E. O Facebook E O Conservadorismo Brasileiro Na Internet: discurso e ideologia. 2018. 154 f. Dissertação (Mestrado) - Curso de Letras, Programa de Pós-Graduação em Estudos da Linguagem, Universidade Estadual de Londrina, Londrina, 2018. Disponível em: http://www.bibliotecadigital.uel.br/document/?view=vtls000223867. Acesso em: 11 maio 2021.

MCINTYRE, J.; YOUENS, B.; STEVENSON, H. Silenced voices: the disappearance of the university and the student teacher in teacher education policy discourse in england. Research Papers In Education, [S.L.], v. 34, n. 2, p. 153168, 14 nov. $2017 . \quad$ Informa UK Limited. http://dx.doi.org/10.1080/02671522.2017.1402084.

MEDEIROS, F. A FUNÇÃO SOCIAL DA ESCOLA NA REFORMA DO ENSINO MÉDIO: À LUZ DA BIOLOGIA. 2018. 145 f. Dissertação (Doutorado) - Curso de Educação, Universidade Estadual do Ceará, Fortaleza, 2018.

MIGUEL, L. F. Da "doutrinação marxista” à "ideologia de gênero" - Escola Sem Partido e as leis da mordaça no parlamento brasileiro. Revista Direito e Práxis, v. 7, n. 15,14 set. 2016.

MINAYO, M. C. D. S.; DESLANDES, S. F.; NETO, O. Pesquisa Social: Teoria. Método e criatividade, 1994.

MINOGUE, K. Liberalismo. In: OUTHWAITE, W; BOTTOMORE, T. Dicionário do pensamento Social do Século XX. Rio de Janeiro: Jorge Zahar Editor, 1993.

MOLE, F. Progressisme social et conservatisme pédagogique dans l'enseignement primaire (France, début XXe siècle). Revista Lusófona de Educação, [S.L.], n. 43, p. 213-224, 1 mar. 2019. Universidade Lusofona de Humanidades e Tecnologias. http://dx.doi.org/10.24140/issn.1645-7250.rle43.14.

MOLL NETO, R; DAMASCENO, R. Uma nação sob risco (de aprender): análise do pensamento neoconservador sobre a educação e a experiência no governo ronald reagan (1981-1989). Praxis Educativa, [S.L.], v. 15, p. 1-25, 2020. Universidade Estadual de Ponta Grossa (UEPG). http://dx.doi.org/10.5212/praxeduc.v.15.16084.072.

MORAIS, E. Religiosidade neopentecostal metainstitucional: uma religiosidade sem limites. 2019. 194 f. Tese (Doutorado) - Curso de Ciências Sociais, Universidade Estadual Paulista - Unesp, Marília, 2019. 
MOREIRA, A L. O PLANO MUNICIPAL DE EDUCAÇÃO DO MUNICÍPIO DE RIO BRANCO/ACRE COMO PLANEJAMENTO DE POLÍTICAS PÚBLICAS NO DECÊNIO (2015-2025): UM ESTUDO DE SEU PROCESSO DE ELABORAÇÃO E CONCEPÇÃO. 2018. 143 f. Dissertação (Mestrado) Curso de Educação, Universidade Federal do Acre, Rio Branco, 2018.

MOREIRA, C. LAICIDADE E HOMOSSEXUALIDADE: O TRATAMENTO DAS REIVINDICAÇÕES LGBT POR PARLAMENTARES EVANGÉLICOS FEDERAIS ENTRE 2010 E 2013. 2014. 164 f. Dissertação (Mestrado) - Curso de Ciências da Religião, Universidade Metodista de São Paulo, São Bernardo do Campo, 2014. Disponível em: http://tede.metodista.br/jspui/bitstream/tede/291/1/Cosme\%20Elexandre.pdf. Acesso em: 11 maio 2021.

MOURA, F. O Movimento Escola Sem Partido e a Reação Conservadora Contra a Discussão de gênero na escola. IN: PENNA, F.; QUEIROZ, F.; FRIGOTTO, G (ORG). Educação Democrática: Antídoto ao Escola sem Partido. Rio de Janeiro: UERJ, LLP, 2018.

MOUTTIN, K. A "ideologia de gênero" através das narrativas da Assembleia Legislativa do Paraná : o caso do Plano Estadual de Educação. 2019. 112 f. Dissertação (Mestrado) - Curso de Educação, Universidade Federal do Paraná, Setor de Educação, Curitiba, 2019. Disponível em: https://acervodigital.ufpr.br/bitstream/handle/1884/62045/R\%20-\%20D\%20$\%$ 20KARINA\%20VEIGA\%20MOTTIN.pdf?sequence=1\&isAllowed=y. Acesso em: 11 maio 2021.

MUDDIMAN, E. Degree subject and orientations to civic responsibility: a comparative study of business and sociology students. Critical Studies In Education, [S.L.], v. 61, n. 5, p. 577-593, 29 out. 2018. Informa UK Limited. http://dx.doi.org/10.1080/17508487.2018.1539020.

MULYA, T.; ADITOMO, A. Researching religious tolerance education using discourse analysis: a case study from indonesia. British Journal Of Religious Education, Uk, v. 41, n. 4, p. 446-457, 16 dez. 2018. Informa UK Limited. http://dx.doi.org/10.1080/01416200.2018.1556602.

MURAKAWA, F.; DELGADO, M. Bancada evangélica veta o nome de Mozart Ramos para Educação. Disponível em: 
<https://valor.globo.com/politica/noticia/2018/11/21/bancada-evangelica-veta-onome-de-mozart-ramos-para-educacao.ghtml>. Acesso em: 13 dez. 2019.

NEUMANN, E; GEWIRTZ, S; MAGUIRE, M; TOWERS, E. Neoconservative education policy and the case of the English Baccalaureate. Journal Of Curriculum Studies, [S.L.], v. 52, n. 5, p. 702-719, 3 jan. 2020. Informa UK Limited. http://dx.doi.org/10.1080/00220272.2019.1708466.

NOBRE, N.; CHALUB, A. Frente parlamentar apoia ensino militar no Brasil. Disponível em: <https://www.camara.leg.br/noticias/555201-FRENTEPARLAMENTAR-APOIA-ENSINO-MILITAR-NO-BRASIL>. Acesso em: 15 nov. 2019.

OAKESHOTT, M. On being conservative. Disponível em: http://www.geocities.com/ Heartland/4887/conservative.html. Acesso: 23/09/2020. OLIVEIRA FILHO, M. O imaginário conservador na educação: uma análise dos discursos das audiências do escola sem partido ( $\mathrm{pl} \mathrm{n}^{\circ}$ 7.180/14). 2019. $130 \mathrm{f}$. Dissertação (Mestrado) - Curso de Ciência Política, Universidade de Brasília, Brasília, 2019. Disponível em: http://repositorio.unb.br/handle/10482/35051. Acesso em: 11 maio 2021.

O'SUlLIVAN, N. Conservatism. In: FREEDEN, M.; STEARS, M. (Eds.). . The Oxford Handbook of Political Ideologies. Oxford: The Oxford University Press, 2013. v. 1p. 1-22.

PALÚ, J; PETRY, O. Neoliberalismo, globalização e neoconservadorismo: cenários e ofensivas contra a educação básica pública brasileira. Praxis Educativa, [S.L.], v. 15, p. 1-21, 2020. Universidade Estadual de Ponta Grossa (UEPG). http://dx.doi.org/10.5212/praxeduc.v.15.15317.063.

PATTILLO-LUNT, A. Surviving the "Sexplosion": christianity today and evangelical sexual ethics in the long 1960s. Religions, [S.L.], v. 12, n. 2, p. 112, 10 fev. 2021. MDPI AG. http://dx.doi.org/10.3390/rel12020112.

PAULINO, C. O Impulso Neoliberal e Neoconservador na Educação Brasileira: A Imagem do "Professor Doutrinador" e "O Projeto Escola sem partido" Revista Educere Et Educare, Cascavel, v. 13, n. 28, p. 118-132, ago. 2018. Disponível em: $\quad$ http://saber.unioeste.br/index.php/educereeteducare/article/view/18731. Acesso em: 16 nov. 2020.

PEACOCK, D. Neoliberal social inclusion? The agenda of the Australian Universities Community Engagement Alliance. Critical Studies In Education, 
[S.L.], v. 53, n. 3, p. 311-325, out. 2012. Informa UK Limited. http://dx.doi.org/10.1080/17508487.2012.703138.

PENNA, F. O Escola sem Partido como chave de leitura do fenômeno educacional. In: FRIGOTTO, G. (Ed.). Escola "sem" Partido: Esfinge que ameaça a educação e a sociedade brasileira. Rio de Janeiro: UERJ, LPP, 2017. p. 35-48.

Construindo estratégias pela educação democrática em tempos de retrocesso. In: PENNA, F.; QUEIROZ, F.; FRIGOTTO, G. (Org). Educação Democrática: Antídoto ao Escola Sem Partido. Rio de Janeiro: UERJ, LPP, 2018. Pág. 89-110.

PERA, G. Governo federal lança programa para a implantação de escolas cívico-militares. Disponível em: <http://escolacivicomilitar.mec.gov.br/noticiaslista/56-governo-federal-lanca-programa-para-a-implantacao-de-escolas-civicomilitares>. Acesso em: 11 nov. 2019.

PERMOSER, J. M.; STOECKL, K, Reframing human rights: the global network of moral conservative homeschooling activists. Global Networks. 2021. Epub: https://doi.org/10.1111/glob.12299

PERONI, V M V; CAETANO, M R; ARELARO, L R G. BNCC: Disputa pela qualidade ou submissão da educação?. Revista Brasileira de Política e Administração da Educação-Periódico científico editado pela ANPAE, v. 35, n. 1, p. 035-056, 2019.

; LIMA, P. Políticas conservadoras e gerencialismo. Praxis Educativa, [S.L.], v. 15, p. 1-20, 2020. Universidade Estadual de Ponta Grossa (UEPG). http://dx.doi.org/10.5212/praxeduc.v.15.15344.070.

.; OLIVEIRA, C M B. O curso Gestão para Aprendizagem da Fundação Lemann como processo de institucionalização do gerencialismo nas escolas de educação básica alagoanas: implicações para a democratização da educação. Educar em Revista [online]. 2020, v. 36, e77554. Disponível em: <https://doi.org/10.1590/0104-4060.77554>. Epub 21 Dez 2020. ISSN 1984-0411. https://doi.org/10.1590/0104-4060.77554.

RELAÇÃO PÚBLICO-PRIVADO NO CONTEXTO DE NEOCONSERVADORISMO NO BRASIL. Educação \& Sociedade [online]. 2020, v. 41, e241697. Disponível em: <https://doi.org/10.1590/ES.241697>. Epub 23 Nov 2020. ISSN 1678-4626. https://doi.org/10.1590/ES.241697. 
PICCININI, C; ANDRADE, M de. O ensino de Ciências da Natureza nas versões da Base Nacional Comum Curricular, mudanças, disputas e ofensiva liberalconservadora. Revista de Ensino de Biologia da Sbenbio, [s. l], v. 11, n. 2, p. 3450, 30 dez. 2018. Disponível em: http://sbenbio.journals.com.br/index.php/sbenbio/article/view/124/32. Acesso em: 15 nov. 2020.

PIMENTEL, P. "Conservadorismo para além do senso comum. Cognitio-Estudos: revista eletrônica de filosofia. 15.2, 2018: 275-286.

PINHEIRO, S. GÊNERO E EDUCAÇÃO ESCOLAR: uma análise das políticas públicas no município de São Luís - MA (2003 - 2014). 2019. 185 f. Tese (Doutorado) - Curso de Educação, Universidade Federal Fluminense, Niterói, 2019.

PITMAN, T. 'Profitable for the country'. An Australian historical perspective of the contested purpose of public universities. Higher Education Research \& Development, [S.L.], v. 39, n. 1, p. 13-25, 2 jan. 2020. Informa UK Limited. http://dx.doi.org/10.1080/07294360.2019.1665627.

POLYAKOVA, T. Y. Modern Trends of Engineering Pedagogy Development. Vysshee Obrazovanie V Rossii = Higher Education In Russia, [S.L.], v. 28, n. 12, p. 132-140, 10 dez. 2019. Moscow Polytechnic University. http://dx.doi.org/10.31992/0869-3617-2019-28-12-132-140

QUADROS, M P R. CONSERVADORISMO À BRASILEIRA: SOCIEDADE E ELITES POLÍTICAS NA CONTEMPORANEIDADE. 2015. 273 f. Tese (Doutorado) - Curso de Ciências Sociais, Pontifícia Universidade Católica do Rio Grande do Sul, Porto Alegre, 2015.

QUINALHA, R. Censura moral na ditadura brasileira: entre o direito e a política / Moral censorship in the Brazilian dictatorship: between law and politics. Revista Direito e Práxis, [S.1.], v. 11, n. 3, p. 1727-1755, set. 2020. ISSN 2179-8966. Disponível em: 〈https://www.epublicacoes.uerj.br/index.php/revistaceaju/article/view/44141 > Acesso: 30 maio 2021.

REZENDE, B. CINEMA E EDUCAÇÃO REPRESENTAÇÃO, HOMOSSEXUALIDADE E JUVENTUDE EM PRAYERS FOR BOBBY (2009). 2018. 164 f. Dissertação (Mestrado) - Curso de Educação, Universidade Federal de Mato Grosso, Cuiabá, 2018. 
RICCI, R. A militarização das escolas públicas - Edição 134. Disponível em: < https://diplomatique.org.br/A-MILITARIZACAO-DAS-ESCOLAS-PUBLICAS> . Acesso em: 09 de jun. de 2019.

RODRIGUES, M.; BOMTEMPO, C. Governo federal quer lançar canal único para denúncias de 'excessos' em sala de aula. Disponível em: <https://g1.globo.com/educacao/noticia/2019/11/20/governo-federal-quer-lancarcanal-unico-para-denuncias-de-excessos-em-sala-de-aula.ghtml>. Acesso em: 13 dez. 2019.

ROSA, R, T, D. Direito à educação democrática: conquistas legais e ameaças: In: PENNA, F.; QUEIROZ, F.; FRIGOTTO, G. (Org). Educação Democrática: Antídoto ao Escola Sem Partido. Rio de Janeiro: UERJ, LPP, 2018. Pág. 51-73. ROSADO-NUNES, M. A “ideologia de gênero" na discussão do PNE. A intervenção da hierarquia católica. HORIZONTE-Revista de Estudos de Teologia e Ciências da Religião, p. 1237-1260, 2015.

ROSENO, C. ESCOLA SEM PARTIDO: UM ATAQUE DIRETO AS POLÍTICAS EDUCACIONAIS DE GÊNERO NO BRASIL. 2017. 91 f. Dissertação (Mestrado) - Curso de Educação, Universidade de Pernambuco, Recife, 2017.

em: https://sucupira.capes.gov.br/sucupira/public/consultas/coleta/trabalhoConclusao/ viewTrabalhoConclusao.jsf?popup=true\&id_trabalho=5056712. Acesso: 11 maio 2021.

SARMENTO, D. O Crucifixo nos tribunais e a laicidade do Estado. Revista Eletrônica PRPE, v. 5, p. 1-17, 2007.

SANTIAGO, N. Tramas entre educação, teoria queer e cinema: um diálogo com os filmes "Febre do rato" e "Tatuagem". 2016. 127 f. Dissertação (Mestrado) - Curso de Educação, Universidade do Estado do Rio de Janeiro, Rio de Janeiro, 2016.

SANTOS, C.; MACHADO, V. Sexo, sexualidade, educação sexual, orientação sexual e diversidade sexual: a análise nas produções de ensino de Ciências. Anais do VII Encontro Nacional de Ensino de Biologia - ENEBIO. Belém: 2018. p. 3925-3534.

SANTOS, R. Conservadorismo na Câmara dos Deputados: discursos sobre “ideologia de gênero" e Escola sem Partido entre 2014 e 2018. Teoria e Cultura, [s. l], v. 13, n. 2, p. 118-132, dez. 2018. Disponível em: 
https://periodicos.ufjf.br/index.php/TeoriaeCultura/article/view/12433. Acesso em: 15 nov. 2020.

SANTOS, R. Vida e movimento na formação dos/as professores/as de história da rede municipal de ensino de Porto Alegre/RS. 2020. 200 f. Dissertação (Mestrado) - Curso de Educação, Instituto de Filosofia e Ciências Humanas. Programa de Pós-Graduação em Ensino de História, Universidade Federal do Rio Grande do Sul, Porto Alegre, 2020. Disponível em: https://lume.ufrgs.br/handle/10183/212272. Acesso em: 11 maio 2021.

SANTOS., R M. As disputas em torno das famílias na câmara dos deputados entre 2007 e 2018: familismo, conservadorismo e neoliberalismo. 2019. 289 f. Tese (Doutorado) - Curso de Ciência Política, Universidade de Brasília, Brasilia, 2018. Disponível em: https://repositorio.unb.br/handle/10482/38470. Acesso em: 11 maio 2021.

SANTOS, R S. SOBREVIVER É RESISTIR: VIDA E MOVIMENTO NA FORMAÇÃO DOS/AS PROFESSORES/AS DE HISTÓRIA DA REDE MUNICIPAL DE ENSINO DE PORTO ALEGRE/RS. 2020. 200 f. Dissertação (Mestrado) - Curso de Ensino de História, Universidade Federal do Rio Grande do Sul, Porto Alegre, 2020. Disponível em: https://lume.ufrgs.br/handle/10183/212272. Acesso em: 11 maio 2021.

SANTOS, T. CORPO, SEXUALIDADE E RESISTÊNCIAS: o contraste entre as propostas dos projetos denominados "Escola sem Partido" e as perspectivas foucaultianas. 2017. 118 f. Dissertação (Mestrado) - Curso de Educação, Universidade Estadual do Mato Grosso do Sul, Dourados, 2017.

SANTOS, W. P.; MORTIMER, E. F. Uma Análise de Pressupostos Teóricos da Abordagem C-T-S (Ciência - Tecnologia - Sociedade) no Contexto da Educação Brasileira. Ensaio - Pesquisa em Educação em Ciências. v. 2, n. 2, dez. 2002. SCRUTON, R. Como ser um conservador. Editora Record, 2015.

SELLES, S.E. A polêmica instituída entre ensino de evolução e criacionismo: dimensões do público e do privado no avanço do neoconservadorismo. Ciência $\boldsymbol{\&}$ Educação (Bauru), [S.L.], v. 22, n. 4, p. 831-835, dez. 2016. FapUNIFESP (SciELO). http://dx.doi.org/10.1590/1516-731320160040001. Disponível em:https://www.scielo.br/scielo.php?pid=S1516$73132016000400831 \&$ script=sci_arttext. Acesso em: 15 nov. 2020. 
; DORVILLÉ, L; PONTUAL, L. Ensino religioso nas escolas estaduais do Rio de Janeiro: implicações para o ensino de ciências/biologia. Ciência \& Educação (Bauru), [S.L.], v. 22, n. 4, p. 875-894, dez. 2016. FapUNIFESP (SciELO). http://dx.doi.org/10.1590/1516-731320160040004. Disponível em: https://www.scielo.br/scielo.php?pid=S151673132016000400875\&script=sci_arttext\&tlng=pt. Acesso em: 15 nov. 2020 SEPULVEDA, J.; SEPULVEDA, D. O pensamento conservador e sua relação com práticas discriminatórias na educação: a importância da laicidade. Revista Teias, v. 17, n. 47, p. 141-154, 2016.

Conservadorismo e seus Impactos no Currículo Escolar. Currículo Sem Fronteiras, v. 19, n. 3, p. 868-892, 31 dez. 2019. Currículo sem Fronteiras. http://dx.doi.org/10.35786/1645-1384.v19.n3.04. Disponível em: https://www.curriculosemfronteiras.org/vol19iss3articles/sepulvedasepulveda.pdf. Acesso em: 15 nov. 2020.

SEVERO, R.; GONÇALVES, S.; ESTRADA, R. A Rede de Difusão do Movimento Escola Sem Partido no Facebook e Instagram: conservadorismo e reacionarismo na conjuntura brasileira. Educação \& Realidade [online]. 2019, v. 44, n. 3, e84073. Disponível em: <https://doi.org/10.1590/2175-623684073>. Epub 12 Ago 2019. ISSN 2175-6236. https://doi.org/10.1590/2175-623684073.

SHANNON-BAKER, P. A Multicultural Education Praxis: integrating past and present, living theories, and practice. International Journal Of Multicultural Education, [S.L.], $\quad$ v. 20, n. 1, p. 48, 28 fev. 2018. Eastern University. http://dx.doi.org/10.18251/ijme.v20i1.1518.

SHAPOSHNIKOV, L E. Philosophical and pedagogic views of N. M. Karamzin. Vestnik Of Saint Petersburg University. Philosophy And Conflict Studies, [S.L.], v. 36, n. 2, p. 300-312, 2020. Saint Petersburg State University. http://dx.doi.org/10.21638/spbu17.2020.208.

SHEPHERD, S. Why are there so few female leaders in higher education. Management In Education, [S.L.], v. 31, n. 2, p. 82-87, abr. 2017. SAGE Publications. http://dx.doi.org/10.1177/0892020617696631.

SHOR, I; SAUL, A; SAUL, A M."O poder que ainda não está no poder": Paulo Freire, pedagogia crítica e a guerra na educação pública - uma entrevista com Ira Shor. Educar em Revista [online]. 2016, v. 00, n. 61 [Acessado 30 Maio 2021], 
pp. 293-308. Disponível em: <https://doi.org/10.1590/0104-4060.46863>. ISSN 1984-0411. https://doi.org/10.1590/0104-4060.46863.

SILVA, É. A educação sexual no currículo da rede estadual de ensino de São Paulo. 2016. 130 f. Monografia (Especialização) - Curso de Educação, Universidade Estadual Paulista (Unesp), São Paulo, 2016. Disponível em: http://hdl.handle.net/11449/141905. Acesso em: 11 maio 2021.

SILVA, I. EM BUSCA DE SIGNIFICADOS PARA A EXPRESSÃO “IDEOLOGIA DE GÊNERO”. Educação em Revista [online]. 2018, v. 34 [Acessado 30 Maio 2021] , e190810. Disponível em: <https://doi.org/10.1590/0102-4698190810>. Epub 13 Dez 2018. ISSN 19826621. https://doi.org/10.1590/0102-4698190810.

SILVA, M. A crise do capital e o projeto reacionário de educação: uma análise do ataque reacionário do Escola Sem Partido ao Colégio Pedro II. 2019. 481 f. Tese (Doutorado) - Curso de Educação, Universidade do Estado do Rio de Janeiro, Rio de Janeiro, 2019.

SILVA JUNIOR, L; LEÃO, M. O software Atlas. ti como recurso para a análise de conteúdo: analisando a robótica no Ensino de Ciências em teses brasileiras. Ciência \& Educação (Bauru), v. 24, n. 3, p. 715-728, 2018.

SOUZA; K.; MENDONÇA, A. A ATUALIDADE DA 'PEDAGOGIA DO OPRIMIDO' NOS SEUS 50 ANOS: A PEDAGOGIA DA REVOLUÇÃO DE PAULO FREIRE. Trabalho, Educação e Saúde [online]. 2019, v. 17, n. 1 [Acessado 30 Maio 2021] , e0018819. Disponível em: <https://doi.org/10.1590/1981-7746-sol00188>. Epub 17 Jan 2019. ISSN 19817746. https://doi.org/10.1590/1981-7746-sol00188.

SILVA, R. NOVOS PANORAMAS PARA O ENSINO RELIGIOSO: Uma análise do modelo das Ciências da Religião para o Ensino Religioso nas escolas públicas, tendo em vista os aspectos da transdisciplinaridade, transreligiosidade e pluralismo religioso. 2017. 149 folhas. Dissertação (Ciências da Religião) - Universidade Metodista de São Paulo, São Bernardo do Campo.

SONETTI, S.; GARCIA, M. ENSINANDO A DIVERSIDADE OU A TRANSFOBIA? UM PANORAMA DA EDUCAÇÃO SOBRE DIVERSIDADE SEXUAL E DE GÊNERO NAS ESCOLAS DA REGIÃO DE SOROCABA-SP E SUA INTERSECÇÃO COM SAÚDE MENTAL. Revista Prâks, [S.L.], v. 1, p. 
173, 10 jan. 2020. Associação Pro-Ensino Superior em Novo Hamburgo. http://dx.doi.org/10.25112/rpr.v1i0.1913.

SPRING, J. Como as corporações globais querem usar as escolas para moldar o homem para o mercado. Campinas: Vide Editorial, 2018.

TATAGIBA, L. Os protestos e a crise brasileira. Um inventário inicial das direitas em movimento (2011 - 2016). In: ALMEIDA, R.; TONIOL, R. Conservadorismos, fascismos e fundamentalismos: análises conjunturais. Editora Unicamp, 2018. Pág. 87 - 116.

TOITIO, R D. Cores e contradições: a luta pela diversidade sexual e de gênero sob o neoliberalismo brasileiro. 2016. 295 f. Tese (Doutorado) - Curso de Ciências Sociais, Universidade Estadual de Campinas, Campinas, 2016.

TOLEDO, R. Homofobia e heterossexismo na escola: um estudo sobre significações de professores gays que atuam na educação básica. 2018. 239 f. Tese (Doutorado) - Curso de Educação, Programa de Estudos Pós-Graduados em Educação: Psicologia da Educação, Pontifícia Universidade Católica de São Paulo, São Paulo, 2018. Disponível em: https://tede2.pucsp.br/handle/handle/21060. Acesso em: 11 maio 2021.

TOMAZELA, J. Primeira escola cívico militar é instalada com polêmica em Sorocaba/SP. Terra. Disponível em: https://www.terra.com.br/noticias/educacao/primeira-escola-civico-militarpaulista-e-instalada-compolemicaemsorocaba,27fe6af9eae8f0fb81790679d392b766ighirdbl.html. Acesso: $21 / 05 / 2021$

TROCH, P. Yugoslavism between the world wars: indecisive nation building. Nationalities Papers, [S.L.], v. 38, n. 2, p. 227-244, mar. 2010. Cambridge University Press (CUP). http://dx.doi.org/10.1080/00905990903517819.

VACCARI, I. GÊNERO, EDUCAÇÃO SEXUAL E ENSINO DE CIÊNCIAS: PERSPECTIVAS DE PROFESSORAS E PROFESSORES DA EDUCAÇÃO. 2018. 117 f. Dissertação (Mestrado) - Curso de Ensino e Processos Formativos, Universidade Estadual Paulista "Júlio de Mesquita Filho", Jaboticabal, 2018. Disponível em: https://repositorio.unesp.br/bitstream/handle/11449/157327/vaccari_il_me_sjrp_p ar.pdf?sequence=6\&isA. Acesso em: 15 nov. 2020. 
VALENTE, F. Administração pública deve flexibilizar data de concurso por motivo religioso. ConJur. 26/11/2020. Disponível em: https://www.conjur.com.br/2020-nov-26/supremo-decide-flexibilizar-dataconcurso-motivo-religioso. Acesso: 21/05/2021

VEIGA, C. DISCRIMINAÇÃO SOCIAL E DESIGUALDADE ESCOLAR NA HISTÓRIA POLÍTICA DA EDUCAÇÃO BRASILEIRA (1822-2016): ALGUNS APONTAMENTOS. História da Educação [online]. 2017, v. 21, n. 53 [Acessado 30 Maio 2021] , pp. 158-181. Disponível em: $<$ https://doi.org/10.1590/2236-3459/73607>. ISSN 2236-3459. https://doi.org/10.1590/2236-3459/73607.

VIEIRA, M. O poder da princesa que ora e espera : práticas e representações do conservadorismo feminino (2000-2017). 2020. $250 \mathrm{f}$. Tese (Doutorado) Curso de História, Universidade Federal do Paraná, Curitiba, 2020. Disponível em: https://acervodigital.ufpr.br/bitstream/handle/1884/69391/R\%20-\%20T\%20$\%$ 20MATHEUS\%20MACHADO $\% 20$ VIEIRA.pdf?sequence $=1 \&$ isAllowed $=\mathrm{y}$. Acesso: 11 maio 2021

VIEIRA, M. C. Vouchers para a educação: entenda os prós e contras. Disponível em: <https://veja.abril.com.br/educacao/vouchers-para-a-educacaoentenda-os-pros-e-contras/>. Acesso em: 11 abr. 2020

VILLAGE, A.; BAKER, S. Rejecting Darwinian Evolution: the effects of education, church tradition, and individual theological stance among uk churchgoers. Review Of Religious Research, [S.L.], v. 60, n. 3, p. 285-303, 17 abr. 2018. Springer Science and Business Media LLC. http://dx.doi.org/10.1007/s13644-018-0335-8.

ZANELLA, F. Queermuseu: Discursos e Sentidos em Exposição. 2020. 144 f. Dissertação (Mestrado em Letras) - Universidade Estadual do Oeste do Paraná, Cascavel PR. Disponível em: http://tede.unioeste.br/handle/tede/4737. Acesso:11/05/2021

ZUHDI, M. Challenging Moderate Muslims: indonesia?s muslim schools in the midst of religious conservatism. Religions, [S.L.], v. 9, n. 10, p. 310, 11 out. 2018. MDPI AG. http://dx.doi.org/10.3390/re19100310. 


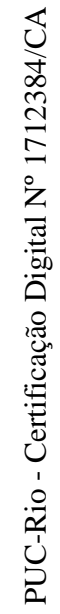




\section{APÊNDICE A - Corpus do levantamento bibliográfico internacional}

\author{
Tratamento Analítico \\ NEWMANN; \\ GEWIRTZ; MAGUIRE; \\ TOWERS (2020) \\ SHAPOSHNIKOV \\ (2020)
}

\section{NETO; DAMASCENO (2020)}

PITMAN, 2020

STOECKEL 2020

JOPLING (2019)

\section{WIJAYA MULYA; \\ ADITOMO 2019}

LAKSANA, WOOD 2019

MOLE (2019)
Análise da atuação conservadora sobre a educação nos EUA

\section{Histórico e Influência} conservadora sobre a Ed. Australiana

Impactos das Políticas Públicas

Neoliberais e Neoconservadoras

Histórico e Influência conservadora sobre a educação nacional (Rússia)

Impactos das Políticas Públicas

Neoliberais e Neoconservadoras

Educação Religiosa

Educação Religiosa

KAHN (2019)

Histórico e Influência conservadora sobre a educação Francesa

Defesa do conservadorismo educacional (por parte da esquerda francesa)

\section{MCINTYRE; YOUENS; STEVENSON, 2019}

ZUHDI, 2018

Impactos das Políticas Públicas Neoliberais e Neoconservadoras sobre a formação de professores na Inglaterra

Educação Religiosa (Indonésia)

KUCUKER, 2018

Impactos das Políticas Públicas Neoliberais e Neoconservadoras
Abordagem Metodológica

Entrevistas e análises quantiquali com professores e gestores de escolas secundárias

Análise de influências conservadoras sobre $\mathrm{o}$ currículo e a formação docente russa. $\mathrm{O}$ ideal militarista, apego à estrutura à ordem e à igreja Análise de documentos oficiais, currículos, propagandas governamentais Análise de legislação, debates parlamentares, atos universitários, artigos de jornais, atas do senado e do conselho docente $\mathrm{e}$ semelhantes

Análise de litigâncias, redes internacionais de atuação, fóruns

Observação participante e entrevistas com professores e pais de alunos de escolas primárias Intervenção pré-pós em turmas de ensino médio, uso de filmes e discussões pró tolerância religiosa Entrevistas e debates sobre a importância da educação religiosa pró tolerância religiosa Análises de projetos de reforma dos métodos curriculares e pedagógicos Análise de discursos, propagandas e defesas realizadas por componentes da esquerda política francesa do conservadorismo educacional enquanto componente de enculturação

Entrevistas com futuros docentes sobre as dificuldades e silenciamentos

Entrevistas com professores de escolas mulçumanas e currículos de disciplinas religiosas

Entrevistas com 30 estudantes turcas sobre as dificuldades de mulheres manterem-se estudando num 


$\begin{array}{cc} & \\ \text { SHANNON-BAKER, } & \text { Resistência e investimento em } \\ 2018 & \text { uma educação } \\ & \text { multicultural/democrática } \\ \text { DANIELSEN; } & \text { Impactos das Políticas Públicas } \\ \text { BUSELIUS; JENSEN; } & \text { Neoliberais e Neoconservadoras } \\ \text { LAITSCH (2017) } & \end{array}$

CARDOSO, MWOLO

(2017)

CHAU; TRAORÉ,
SECK, CHANDRA-
MOULI; SVANEMYR,
(2016)
SIMMIE; EDLING
(2016)

BAGLEY; BEACH (2015)

CLARK (2012) Impactos de políticas neoliberais e Neoconservador na Educação

cenário de conservadorismo político, cultural e dificuldades econômicas Reflexão teórico- conceitual transnacional sobre o avanço neoconservador educacional

Análises de políticas públicas, entrevistas com gestores e professores da educação primária sobre a saúde (Dinamarca)

Análise da atuação de ONGs e espaços não formais que atuam pela educação sexual na Tanzânia Análise de Surveys produzidos pela Organização Mundial da Saúde e dados nacionais do Senegal

Estudo comparativo entre Surveys e dados oficiais produzidos por Suécia e Irlanda

Análise teórico conceitual sobre a formação de professores da Inglaterra Teórico conceitual

Teórico conceitual

Análise de políticas públicas, entrevistas com estudantes e egressos do ensino superior australiano

Análise dos resultados obtidos entre a universidade e comunidades e organizações econômicas externas. (Austrália)

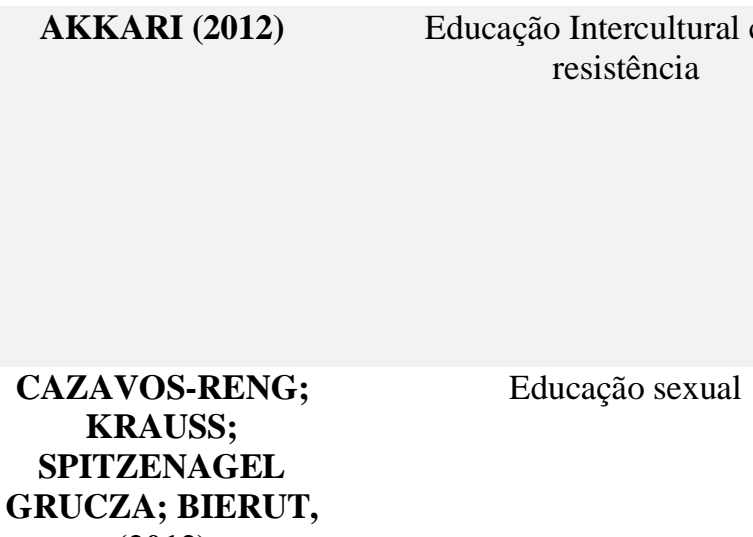

(2012)

Reflexões teórico conceitual sobre os avanços conservadores sobre a educação australiana

Reflexão teórico conceitual sobre a dificuldade brasileira de trazer a diversidade cultural e étnica para as salas de aulas. Discute as possibilidades de avanço sociocultural apartir dessas discussões em ambiente escolar

Análise de dados demográficos, planos escolares entre 1997-2005.

Estados mais conservadores e religiosos possuem maior taxa de natalidade a despeito do investimento em educação sexual 
BENCZE; CARTER, Economização educacional (2011)

BENCZE (2010)

TROCH (2010)
Economização educacional

Influências conservadoras sobre a educação (IUGUSLÁVIA)
Teórico conceitual sobre o avanço neoliberal transnacional sobre a educação

Teórico conceitual sobre o avanço neoliberal transnacional sobre a educação

Análise das políticas públicas educacionais voltadas para a perpetuação econômica das elites e pautada no autoritarismo nacionalista
Tratamento Argumentativo

PATTILO-LUNT (2021)

GRAFF (2018)

ECKULUND;

BOLGER (2017)

\section{Abordagem Metodológica}

Análise de uma revista evangélica que forjava uma ética sexual cristão conservadora em oposição à imoralidade em campus universitários nos anos 1960 EUA Entrevistas com grupos universitários conservadores e sua adesão ao Trumpismo Entrevistas com fiéis religiosos sobre o impacto de sua fé e percepção sobre gênero e sexualidade

Rejeição à conteúdos e conhecimentos sobre evolução biológica entre frequentadores assíduos de templos religiosos (UK).

Entrevistas e Questionários

Reflexão teórico-conceitual sobre agenda transnacional anti-gênero

WCHEITLE; PEIFER,

Moralidade Religiosa e

Sexualidade

Religiosidade e Rejeição

Científica

SHEPPERD (2017)

Implicações conservadoras sobre a inserção feminina no mercado de trabalho
Rejeição à conteúdos e conhecimentos sobre evolução biológica e mudança climática entre frequentadores assíduos de templos religiosos (UK). Entrevistas e Questionários Análise de entrevistas com gestoras mulheres do Ensino Superior 


\section{APÊNDICE B - Corpus do levantamento bibliográfico nacional}

\begin{tabular}{|c|c|c|c|c|}
\hline $\begin{array}{l}\text { Tratamento } \\
\text { Analítico }\end{array}$ & $\begin{array}{c}\text { Discussões sobre } \\
\text { Diversidade } \\
\text { educação }\end{array}$ & $\begin{array}{l}\text { Discussões sobre } \\
\text { Laicidade e } \\
\text { moralização } \\
\text { religiosa }\end{array}$ & $\begin{array}{l}\text { Natureza e Atuação } \\
\text { Conservadora }\end{array}$ & $\begin{array}{c}\text { Discussões } \\
\text { sobre } \\
\text { Educação, } \\
\text { Democracia e } \\
\text { Resistência }\end{array}$ \\
\hline BDTD & $\begin{array}{l}\text { Almeida (2018)T; } \\
\text { Silva (2016); }\end{array}$ & $\begin{array}{l}\text { Silva (2017); Alves } \\
\text { (2020) Coelho (2017) } \\
\text { D; Mouttin (2019) D; } \\
\text { Jacó (2019), D; }\end{array}$ & $\begin{array}{l}\text { Lima (2020) D; } \\
\text { Avelar (2019) D; } \\
\text { Oliveira Filho (2019) } \\
\text { D; lira (2018) D; } \\
\text { Freire (2018) D; }\end{array}$ & $\begin{array}{l}\text { Santos (2020); } \\
\text { Leme } \\
\text { (2018)D; Silva } \\
\text { (2020) D; }\end{array}$ \\
\hline CAPES & $\begin{array}{c}\text { Honorato (2018) } \\
\text { D; Roseno (2017) } \\
\text { D; Santiago } \\
\text { (2016) D; } \\
\text { Pinheiro (2019) } \\
\text { T; Camargo } \\
\text { (2019) D; Santos } \\
\text { (2017) D; Toledo } \\
\text { (2018) T; }\end{array}$ & & $\begin{array}{l}\text { Silva (2019) T; } \\
\text { Medeiros (2018) D; } \\
\text { Moreira (2018) D }\end{array}$ & $\begin{array}{l}\text { Albuquerque } \\
\text { (2019) D; } \\
\text { Gomes (2018) }\end{array}$ \\
\hline SciELO & & $\begin{array}{c}\text { Carvalho; Sívori } \\
\text { (2017); Silva (2018); } \\
\text { Selles (2016); Selles } \\
\text { et al (2016) }\end{array}$ & $\begin{array}{c}\text { Veiga (2017); } \\
\text { Aragusuku; Lopes } \\
\text { (2018); Lima; } \\
\text { Hypólito (2019); } \\
\text { Severo et al (2019); } \\
\text { Peroni (2020); Peroni; } \\
\text { Oliverira (2020); } \\
\text { Editores da Revista } \\
\text { Educação e Sociedade } \\
\text { (2020). }\end{array}$ & $\begin{array}{l}\text { Souza; } \\
\text { Mendonça } \\
\text { (2019); Shor } \\
\text { et al (2016) }\end{array}$ \\
\hline Scopus & $\begin{array}{l}\text { Sonetti; Garcia } \\
\quad(2020)\end{array}$ & $\begin{array}{c}\text { Cecchetti; Tedesco } \\
\text { (2020); }\end{array}$ & $\begin{array}{l}\text { Campos (2020); } \\
\text { Pieroni; lima (2020); } \\
\text { Palú; Petry ( 2020) }\end{array}$ & $\begin{array}{l}\text { Carvalho } \\
\text { (2019) }\end{array}$ \\
\hline $\begin{array}{c}\text { Tratamento } \\
\text { Argumentativo }\end{array}$ & $\begin{array}{l}\text { Discussões sobre } \\
\text { Diversidade }\end{array}$ & $\begin{array}{l}\text { Discussões sobre } \\
\text { Laicidade e } \\
\text { Dimensões } \\
\text { Público/Privadas }\end{array}$ & $\begin{array}{l}\text { Natureza e Atuação } \\
\text { Conservadora }\end{array}$ & \\
\hline BDTD & $\begin{array}{c}\text { Felicissímo } \\
\text { (2014) T; Cunha } \\
\text { (2019) D; Grecco } \\
\text { (2018) D; Zanella } \\
\text { (2020) D; }\end{array}$ & $\begin{array}{c}\text { Moreira (2014) D; } \\
\text { Gomes (2019) D; } \\
\text { Caldeira (2018) D; } \\
\text { Morais (2019) T; } \\
\text { Vieira (2017) T; } \\
\text { Koren (2016) D }\end{array}$ & $\begin{array}{c}\text { Dias (2017) D; Santos } \\
\text { (2019) T; Mayer } \\
\text { (2018) D. }\end{array}$ & \\
\hline CAPES & $\begin{array}{c}\text { Rezende (2018) } \\
\text { D; Toitio (2016) } \\
\text { T. }\end{array}$ & & $\begin{array}{l}\text { Quadros (2015) T; } \\
\text { Lacerda (2018) T; }\end{array}$ & \\
\hline
\end{tabular}




\section{APÊNDICE C - Lista de iniciativas parlamentares conservadoras relacionadas à educação}

\begin{tabular}{|c|c|c|c|c|c|c|c|}
\hline Iniciativa & Ano & Caráter & Tema & $\begin{array}{l}\text { Primeiro } \\
\text { Autor }\end{array}$ & UF & Partido & Situação \\
\hline PL 6001/2001 & 2001 & Conservador & Homeschooling & Ricardo Izar & SP & PTB & Arquivada \\
\hline PL 6484/2002 & 2002 & Conservador & Homeschooling & Osório Adriano & DF & PFL & Arquivada \\
\hline PL 1125/2003 & 2003 & Conservador & Homeschooling & Ricardo Izar & SP & PTB & Devolvida ao autor \\
\hline PL $4122 / 2008$ & 2008 & Conservador & Homeschooling & $\begin{array}{l}\text { Walter Brito } \\
\text { Neto }\end{array}$ & PB & PRB & Arquivada \\
\hline PL 3518/2008 & 2008 & Conservador & Homeschooling & $\begin{array}{c}\text { Henrique } \\
\text { Afonso }\end{array}$ & $\mathrm{AC}$ & PT & Arquivada \\
\hline PEC 444/2009 & 2009 & Conservador & Homeschooling & Wilson Picler & PR & PDT & Arquivada \\
\hline PL 3179/2012 & 2012 & Conservador & Homeschooling & Lincoln Portela & MG & PR & $\begin{array}{c}\text { Aguardando } \\
\text { Constituição de } \\
\text { Comissão Temporária } \\
\text { pela Mesa }\end{array}$ \\
\hline PL3261/2015 & 2015 & Conservador & Homeschooling & $\begin{array}{l}\text { Eduardo } \\
\text { Bolsonaro }\end{array}$ & SP & PSC & $\begin{array}{c}\text { Apensado ao PL } \\
3179 / 2012\end{array}$ \\
\hline PL 10185/2018 & 2018 & Conservador & Homeschooling & Alan Rick & $\mathrm{AC}$ & DEM & $\begin{array}{c}\text { Apensado ao PL } \\
3179 / 2012\end{array}$ \\
\hline PL 3262/2019 & 2019 & Conservador & Homeschooling & Chris Tonietto & RJ & PSL & $\begin{array}{c}\text { Apensado ao PL } \\
3179 / 2012\end{array}$ \\
\hline P $\quad 401 / 2019$ & 2019 & Conservador & Homeschooling & $\begin{array}{l}\text { Poder } \\
\text { Executivo }\end{array}$ & DF & SEM PARTIDO & $\begin{array}{c}\text { Apensado ao PL } \\
3179 / 2012\end{array}$ \\
\hline 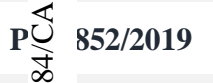 & 2019 & Conservador & Homeschooling & Pr Eurico & PE & PATRIOTA & $\begin{array}{c}\text { Apensada ao PL } \\
3179 / 2012\end{array}$ \\
\hline 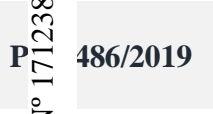 & 2019 & Conservador & Homeschooling & Pr Eurico & $\mathrm{PE}$ & PATRIOTA & $\begin{array}{l}\text { Tramitando em } \\
\text { Conjunto PL- } \\
4965 / 2019\end{array}$ \\
\hline 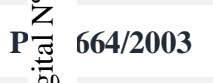 & 2003 & Conservador & $\begin{array}{l}\text { Liberdade Religiosa } \\
\text { / Laicidade }\end{array}$ & Adelor Vieira & $\mathrm{SC}$ & PMDB & $\begin{array}{c}\text { Apensado ao PL } \\
5 / 1999\end{array}$ \\
\hline 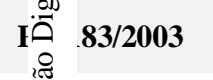 & 2003 & Conservador & Ensino Religioso & $\begin{array}{l}\text { Maurício } \\
\text { Rabelo }\end{array}$ & TO & PL & Arquivada \\
\hline$P: \overbrace{\overparen{D}}^{\overparen{巳}}$ & 2003 & Conservador & Ensino Religioso & $\begin{array}{l}\text { Professor } \\
\text { Irapuan } \\
\text { Teixeira }\end{array}$ & SP & SEM PARTIDO & Arquivada \\
\hline IN ;078/2005 & 2005 & Conservador & Criacionismo & Milton Cardias & $\mathrm{RS}$ & PTB & Arquivada \\
\hline P: & 2005 & Conservador & $\begin{array}{l}\text { Liberdade Religiosa } \\
\text { / Laicidade }\end{array}$ & Takayama & PR & PMDB & $\begin{array}{c}\text { Aguardando } \\
\text { Definição } \\
\text { Encaminhamento; } \\
\text { Aguardando } \\
\text { Constituição de } \\
\text { Comissão Temporária }\end{array}$ \\
\hline PL 5198/2005 & 2005 & Conservador & Ensino Religioso & $\begin{array}{l}\text { Professor } \\
\text { Irapuan } \\
\text { Teixeira }\end{array}$ & SP & $\mathrm{PP}$ & Arquivada \\
\hline PL 4922/2005 & 2005 & Conservador & $\begin{array}{l}\text { Valores e suportes } \\
\text { religiosos }\end{array}$ & José Divino & $\mathrm{RJ}$ & PMDB & Arquivada \\
\hline PL 2407/2007 & 2007 & Conservador & $\begin{array}{l}\text { Valores e suportes } \\
\text { religiosos }\end{array}$ & $\begin{array}{c}\text { Professor } \\
\text { Victorio Galli }\end{array}$ & MT & PMDB & Arquivada \\
\hline PL 1065/2007 & 2007 & Conservador & Ensino Religioso & Miguel Martini & MG & PHS & Arquivada \\
\hline PL 678/2007 & 2007 & Conservador & Ensino Religioso & $\begin{array}{l}\text { Bonifácio de } \\
\text { Andrada }\end{array}$ & MG & PSDB & Arquivada \\
\hline PL 5598/2009 & 2009 & Conservador & Ensino Religioso & George Hilton & MG & PP & Arquivada \\
\hline PL 309/2011 & 2011 & Conservador & Ensino Religioso & $\begin{array}{l}\text { Pr Marco } \\
\text { Feliciano }\end{array}$ & SP & PSC & $\begin{array}{l}\text { Aguardando Parecer } \\
\text { do Relator na } \\
\text { Comissão de } \\
\text { Educação (CE) }\end{array}$ \\
\hline PL 1021/2011 & 2011 & Conservador & Ensino Religioso & $\begin{array}{l}\text { Pr Marco } \\
\text { Feliciano }\end{array}$ & SP & PSC & Retirada pelo Autor \\
\hline PL 605/2011 & 2011 & Conservador & $\begin{array}{l}\text { Liberdade Religiosa } \\
\text { / Laicidade }\end{array}$ & Weliton Prado & MG & PT & $\begin{array}{l}\text { Tramitando em } \\
\text { Conjunto }\end{array}$ \\
\hline
\end{tabular}




\begin{tabular}{|c|c|c|c|c|c|c|c|}
\hline PL 4293/2012 & 2012 & Conservador & $\begin{array}{l}\text { Valores e suporte } \\
\text { religiosos }\end{array}$ & $\begin{array}{c}\text { Professor } \\
\text { Victório Galli }\end{array}$ & MT & PMDB & Arquivada \\
\hline PL 5618/2013 & 2013 & Conservador & $\begin{array}{l}\text { Valores e suportes } \\
\text { religiosos na } \\
\text { sociedade }\end{array}$ & $\begin{array}{c}\text { Erivelton } \\
\text { Santana }\end{array}$ & BA & PSC & Arquivada \\
\hline PL 8099/2014 & 2014 & Conservador & Criacionismo & $\begin{array}{l}\text { Pr Marco } \\
\text { Feliciano }\end{array}$ & SP & PSC & $\begin{array}{c}\text { Tramitando em } \\
\text { Conjunto - Apensado } \\
\text { ao PL 309/2011 }\end{array}$ \\
\hline PL 3044/2015 & 2015 & Conservador & Ensino Religioso & Takayama & PR & PSC & $\begin{array}{c}\text { Tramitando em } \\
\text { Conjunto }\end{array}$ \\
\hline PL 2873/2015 & 2015 & Conservador & $\begin{array}{l}\text { Valores e suporte } \\
\text { religioso sociedade }\end{array}$ & Takayama & PR & PSC & $\begin{array}{c}\text { Apensado ao PL } \\
2085 / 1999\end{array}$ \\
\hline PL 1219/2015 & 2015 & Conservador & $\begin{array}{l}\text { Liberdade Religiosa } \\
\text { / Laicidade }\end{array}$ & $\begin{array}{l}\text { Leonardo } \\
\text { Quintão }\end{array}$ & MG & PMDB & Retirado pelo Autor \\
\hline PL 943/2015 & 2015 & Conservador & Ensino Religioso & Alfredo Kaefer & PR & PSDB & $\begin{array}{l}\text { Tramitando em } \\
\text { Conjunto }\end{array}$ \\
\hline PL 5336/2016 & 2016 & Conservador & Criacionismo & $\begin{array}{l}\text { Jefferson } \\
\text { Campos }\end{array}$ & SP & PSD & $\begin{array}{c}\text { Apensado ao PL } \\
8099 / 2014\end{array}$ \\
\hline PL 9164/2017 & 2017 & Conservador & Ensino Biblía & Cabo Daciolo & $\mathrm{RJ}$ & AVANTE & $\begin{array}{c}\text { Apensado ao PL } \\
943 / 2015\end{array}$ \\
\hline PL 9810/2018 & 2018 & Conservador & Ensino Religioso & Hugo Leal & $\mathrm{RJ}$ & PSB & Devolvida ao Autor \\
\hline PL 701/2019 & 2019 & Conservador & Ensino Religioso & Otoni de Paula & $\mathrm{RJ}$ & PSC & $\begin{array}{c}\text { Tramitando em } \\
\text { Conjunto }\end{array}$ \\
\hline PL 4413/2019 & 2019 & Conservador & $\begin{array}{l}\text { Valores e suportes } \\
\text { religiosos na } \\
\text { educação }\end{array}$ & Dr. Jaziel & $\mathrm{CE}$ & PL & $\begin{array}{l}\text { Tramitando em } \\
\text { Conjunto }\end{array}$ \\
\hline PI . 772/2003 & 2003 & Conservador & $\begin{array}{l}\text { Educação Moral / } \\
\text { Patriotismo }\end{array}$ & $\begin{array}{c}\operatorname{Pr} \\
\text { Frankembergen }\end{array}$ & $\mathrm{RR}$ & РTB & Arquivada \\
\hline$P_{\overparen{\bigcup}} 072 / 2005$ & 2005 & Conservador & $\begin{array}{c}\text { Educação Moral / } \\
\text { Patriotismo }\end{array}$ & Carlos Nader & $\mathrm{RJ}$ & PL & Arquivada \\
\hline 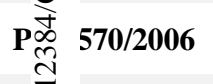 & 2006 & Conservador & $\begin{array}{c}\text { Educação Moral / } \\
\text { Patriotismo }\end{array}$ & $\begin{array}{c}\operatorname{Pr} \\
\text { Frankembergen }\end{array}$ & $\mathrm{RR}$ & РTB & Arquivada \\
\hline I & 2011 & Conservador & Doutrinação & $\begin{array}{l}\text { Marcelo } \\
\text { Aguiar }\end{array}$ & SP & PSC & Retirado pelo Autor \\
\hline 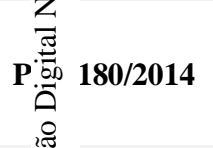 & 2014 & Conservador & Doutrinação & $\begin{array}{c}\text { Erivelton } \\
\text { Santana }\end{array}$ & $\mathrm{BA}$ & PSC & $\begin{array}{c}\text { Aguardando } \\
\text { Constituição de } \\
\text { Comissão Temporária } \\
\text { pela Mesa }\end{array}$ \\
\hline I: & 2015 & Conservador & Escola Sem Partido & Izalci & DF & PSDB & $\begin{array}{l}\text { Tramitando em } \\
\text { Conjunto;Tramitando } \\
\text { em Conjunto }\end{array}$ \\
\hline$P$ & 2016 & Conservador & $\begin{array}{l}\text { Doutrinação } \\
\text { Ideológica }\end{array}$ & $\begin{array}{c}\text { Eduardo } \\
\text { Bolsonaro }\end{array}$ & $\mathrm{SP}$ & $\mathrm{PSC}$ & Aguardando Parecer \\
\hline 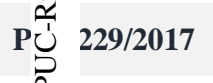 & 2017 & Conservador & Doutrinação & $\begin{array}{c}\text { Professor } \\
\text { Victório Galli }\end{array}$ & MT & PSC & $\begin{array}{c}\text { Apensado ao PL } \\
5358 / 2016\end{array}$ \\
\hline PDC 888/2018 & 2018 & Conservador & $\begin{array}{c}\text { Doutrinação } \\
\text { Ideológica }\end{array}$ & Flavinho & $\mathrm{SP}$ & PSB & Devolvida ao Autor \\
\hline PL 10659/2018 & 2018 & Conservador & $\begin{array}{l}\text { Doutrinação } \\
\text { Ideológica }\end{array}$ & $\begin{array}{l}\text { Delegado } \\
\text { Waldir }\end{array}$ & GO & PSL & $\begin{array}{l}\text { Tramitando em } \\
\text { Conjunto;Tramitando } \\
\text { em Conjunto }\end{array}$ \\
\hline PL 9957/2018 & 2018 & Conservador & $\begin{array}{l}\text { Doutrinação } \\
\text { Ideológica }\end{array}$ & $\begin{array}{l}\text { Jhonatan de } \\
\text { Jesus }\end{array}$ & $\mathrm{RR}$ & PRB & $\begin{array}{c}\text { Tramitando em } \\
\text { Conjunto;Tramitando } \\
\text { em Conjunto }\end{array}$ \\
\hline PL 246/2019 & 2019 & Conservador & Escola Sem Partido & Bia Kicis & DF & PSL & $\begin{array}{c}\text { Apensado ao PL } \\
867 / 2015\end{array}$ \\
\hline PL 258/2019 & 2019 & Conservador & $\begin{array}{l}\text { Doutrinação } \\
\text { Ideológica }\end{array}$ & Pr Eurico & PE & PATRI & $\begin{array}{c}\text { Tramitando em } \\
\text { Conjunto;Tramitando } \\
\text { em Conjunto }\end{array}$ \\
\hline PL 4826/2019 & 2019 & Conservador & Comunismo & Julian Lemos & PB & PMDB & $\begin{array}{l}\text { Tramitando em } \\
\text { Conjunto }\end{array}$ \\
\hline PL 3674/2019 & 2019 & Conservador & Doutrinação & Helio Lopes & RJ & PSL & $\begin{array}{c}\text { Apensado ao PL } \\
7180 / 2014\end{array}$ \\
\hline PL 2692/2019 & 2019 & Conservador & $\begin{array}{l}\text { Doutrinação } \\
\text { Ideológica }\end{array}$ & Otoni de Paula & RJ & PSC & $\begin{array}{c}\text { Tramitando em } \\
\text { Conjunto }\end{array}$ \\
\hline PL 4887 /2019 & 2019 & Conservador & $\begin{array}{l}\text { Militarização } \\
\text { Escolar }\end{array}$ & Carla Zambelli & $\mathrm{SP}$ & PSL & $\begin{array}{l}\text { Encaminhada para } \\
\text { Publicação }\end{array}$ \\
\hline
\end{tabular}




\begin{tabular}{|c|c|c|c|c|c|c|c|}
\hline INC 275/2019 & 2019 & Conservador & $\begin{array}{l}\text { Militarização } \\
\text { escolar }\end{array}$ & $\begin{array}{l}\text { Gutemberg } \\
\text { Reis }\end{array}$ & RJ & MDB & $\begin{array}{l}\text { Encaminhada para } \\
\text { Publicação }\end{array}$ \\
\hline PL 3168/2020 & 2020 & Conservador & Escola Sem Partido & Daniel Silveira & RJ & PSL & $\begin{array}{c}\text { Apensado ao PL } \\
9957 / 2018\end{array}$ \\
\hline PL 2992/2020 & 2020 & Conservador & $\begin{array}{c}\text { Doutrinação } \\
\text { Ideológica }\end{array}$ & $\begin{array}{l}\text { Alexandre } \\
\text { Frota }\end{array}$ & SP & PSDB & $\begin{array}{l}\text { Aguardando } \\
\text { Despacho do } \\
\text { Presidente da Câmara } \\
\text { dos Deputados }\end{array}$ \\
\hline PL 1256/2003 & 2003 & Conservador & $\begin{array}{c}\text { Orientação/Proteção } \\
\text { Sexual }\end{array}$ & Takayama & PR & PSB & Arquivada \\
\hline PL 1399/2003 & 2003 & Conservadora & Gênero & $\begin{array}{l}\text { Renato } \\
\text { Cozzolino }\end{array}$ & RJ & PSC & Arquivada \\
\hline PL 5918/2005 & 2005 & Conservador & Educação Sexual & $\begin{array}{c}\text { Elimar } \\
\text { Máximo } \\
\text { Damasceno }\end{array}$ & SP & PRONA & Arquivada \\
\hline PL 42/2007 & 2007 & Conservador & $\begin{array}{l}\text { Educação sexual / } \\
\text { Ensino Religioso }\end{array}$ & Lincoln Portela & MG & PR & Pronta para Pauta \\
\hline PL 7887/2010 & 2010 & Conservador & $\begin{array}{c}\text { Orientação/Proteção } \\
\text { Sexual }\end{array}$ & $\begin{array}{l}\text { Francisco } \\
\text { Rossi }\end{array}$ & SP & PMDB & Devolvida ao Autor \\
\hline PL 1618/2011 & 2011 & Conservador & $\begin{array}{c}\text { Orientação/Proteção } \\
\text { Sexual }\end{array}$ & Roberto Britto & BA & PP & Arquivada \\
\hline PL 1911/2011 & 2011 & Conservador & $\begin{array}{c}\text { Orientação/Proteção } \\
\text { Sexual }\end{array}$ & Neilton Mulim & RJ & PR & $\begin{array}{c}\text { Tramitando em } \\
\text { Conjunto }\end{array}$ \\
\hline PL 7181/2014 & 2014 & Conservador & Educação Sexual & $\begin{array}{l}\text { Erivelton } \\
\text { Santana }\end{array}$ & BA & PSC & $\begin{array}{l}\text { Tramitando em } \\
\text { Conjunto;Tramitando } \\
\text { em Conjunto }\end{array}$ \\
\hline PI . 7551/2014 & 2014 & Conservador & $\begin{array}{l}\text { Gênero na } \\
\text { sociedade }\end{array}$ & $\begin{array}{l}\text { Salvador } \\
\text { Zimbaldi }\end{array}$ & SP & PROS & Arquivada \\
\hline$P_{\mho} \quad 26 / 2015$ & 2015 & Conservador & Ideologia de Gênero & $\begin{array}{l}\text { Ezequiel } \\
\text { Teixeira }\end{array}$ & RJ & SD & $\begin{array}{c}\text { Apensado ao PDC } \\
16 / 2015\end{array}$ \\
\hline$P]{ }_{\infty}^{\prime} 122 / 2015$ & 2015 & Conservador & Ideologia de Gênero & FLAVINHO & SP & PSB & Devolvida ao Autor \\
\hline$P_{\overparen{C}}^{\infty} 30 / 2015$ & 2015 & Conservador & Ideologia de Gênero & Eros Biondini & MG & PTB & Apensada \\
\hline P & 2015 & Conservador & Ideologia de Gênero & $\begin{array}{l}\text { Pr Marco } \\
\text { Feliciano }\end{array}$ & & PSC & $\begin{array}{l}\text { Aguardando } \\
\text { Designação de } \\
\text { Relator }\end{array}$ \\
\hline 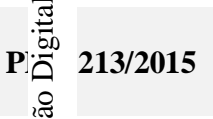 & 2015 & Conservador & Ideologia de Gênero & $\begin{array}{c}\text { Professor } \\
\text { Victório Galli }\end{array}$ & MT & PSC & $\begin{array}{l}\text { Aguardando } \\
\text { Designação de } \\
\text { Relator }\end{array}$ \\
\hline 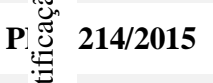 & 2015 & Conservador & Ideologia de Gênero & Pr Eurico & $\mathrm{PE}$ & PSB & $\begin{array}{l}\text { Tramitando em } \\
\text { Conjunto }\end{array}$ \\
\hline$P_{1} 859 / 2015$ & 2015 & Conservador & Ideologia de Gênero & Alan Rick & $\mathrm{AC}$ & PRB & $\begin{array}{c}\text { Tramitando em } \\
\text { Conjunto;Tramitando } \\
\text { em Conjunto }\end{array}$ \\
\hline$P=731 / 2015$ & 2015 & Conservador & Ideologia de Gênero & Eros Biondini & MG & PTB & Retirado pelo Autor \\
\hline$P_{2}^{2}$ 235/2015 & 2015 & Conservador & Ideologia de Gênero & $\begin{array}{l}\text { Pr Marco } \\
\text { Feliciano }\end{array}$ & SP & PSC & Aguardando Parecer \\
\hline PL 3236/2015 & 2015 & Conservador & Ideologia de Gênero & $\begin{array}{l}\text { Pr Marco } \\
\text { Feliciano }\end{array}$ & SP & PSC & Retirado pelo Autor \\
\hline PDC 91/2015 & 2015 & Conservador & Ideologia de Gênero & Fábio Sousa & GO & PSDB & $\begin{array}{c}\text { Apensado ao PDC } \\
16 / 2015\end{array}$ \\
\hline PDC 48/2015 & 2015 & Conservador & Ideologia de Gênero & $\begin{array}{c}\text { Professor } \\
\text { Victório Galli }\end{array}$ & MT & PSC & $\begin{array}{c}\text { Apensado ao PDC } \\
16 / 2015\end{array}$ \\
\hline PDC 115/2015 & 2015 & Conservador & Ideologia de Gênero & Alfredo Kaefer & PR & PSDB & $\begin{array}{l}\text { Tramitando em } \\
\text { Conjunto }\end{array}$ \\
\hline PL 891/2015 & 2015 & Conservador & Educação Sexual & Flavinho & SP & PSB & $\begin{array}{l}\text { Tramitando em } \\
\text { Conjunto }\end{array}$ \\
\hline PL 5745/2016 & 2016 & Conservador & Educação Sexual & Felipe Bornier & RJ & PROS & $\begin{array}{l}\text { Tramitando em } \\
\text { Conjunto }\end{array}$ \\
\hline PL 5487/2016 & 2016 & Conservador & Ideologia de Gênero & $\begin{array}{c}\text { Professor } \\
\text { Victório Galli }\end{array}$ & MT & PSC & $\begin{array}{l}\text { Tramitando em } \\
\text { Conjunto;Tramitando } \\
\text { em Conjunto }\end{array}$ \\
\hline PL 5686/2016 & 2016 & Conservador & $\begin{array}{l}\text { Gênero na } \\
\text { Sociedade }\end{array}$ & $\begin{array}{c}\text { Professor } \\
\text { Victório Galli }\end{array}$ & MT & PSC & Retirado pelo Autor \\
\hline PL 5774/2016 & 2016 & Conservador & $\begin{array}{l}\text { Gênero na } \\
\text { sociedade }\end{array}$ & $\begin{array}{c}\text { Professor } \\
\text { Victório Galli }\end{array}$ & MT & PSC & $\begin{array}{l}\text { Aguardando } \\
\text { Designaçãão de } \\
\text { Relator }\end{array}$ \\
\hline
\end{tabular}




\begin{tabular}{|c|c|c|c|c|c|c|c|}
\hline PL 6355/2016 & 2016 & Conservador & Educação Sexual & Cleber Verde & MA & PRB & $\begin{array}{l}\text { Tramitando em } \\
\text { Conjunto }\end{array}$ \\
\hline PL 8933/2017 & 2017 & Conservador & Educação Sexual & Pr Eurico & $\mathrm{PE}$ & PHS & $\begin{array}{c}\text { Tramitando em } \\
\text { Conjunto;Tramitando } \\
\text { em Conjunto }\end{array}$ \\
\hline PDC $1094 / 2018$ & 2018 & Conservador & Ideologia de Gênero & Diego Garcia & PR & PODE & $\begin{array}{l}\text { Aguardando } \\
\text { Designação de } \\
\text { Relator }\end{array}$ \\
\hline PL 9742/2018 & 2018 & Conservador & $\begin{array}{l}\text { Gênero na } \\
\text { sociedade }\end{array}$ & $\begin{array}{l}\text { Sóstenes } \\
\text { Cavalcante }\end{array}$ & $\mathrm{RJ}$ & DEM & $\begin{array}{c}\text { Apensada ao PL } \\
5774 / 2016\end{array}$ \\
\hline PL 10577/2018 & 2018 & Conservador & Ideologia de Gênero & Cabo Daciolo & RJ & PATRIOTA & $\begin{array}{c}\text { Apensada ao PL } \\
1859 / 2015\end{array}$ \\
\hline PL 9948/2018 & 2018 & Conservador & Ideologia de Gênero & Cabo Daciolo & $\mathrm{RJ}$ & PATRIOTA & $\begin{array}{l}\text { Tramitando em } \\
\text { Conjunto;Tramitando } \\
\text { em Conjunto }\end{array}$ \\
\hline PDL 520/2019 & 2019 & Conservador & Ideologia de Gênero & $\begin{array}{l}\text { Vinicius } \\
\text { Carvalho }\end{array}$ & SP & PRB & $\begin{array}{c}\text { Tramitando em } \\
\text { Conjunto;Tramitando } \\
\text { em Conjunto }\end{array}$ \\
\hline PL 1239/2019 & 2019 & Conservador & Ideologia de Gênero & $\begin{array}{l}\text { Pr Sargento } \\
\text { Isidório }\end{array}$ & BA & AVANTE & $\begin{array}{l}\text { Tramitando em } \\
\text { Conjunto }\end{array}$ \\
\hline PL 1297/2019 & 2019 & Conservador & $\begin{array}{l}\text { Gênero na } \\
\text { Sociedade }\end{array}$ & Carlos Jordy & $\mathrm{RJ}$ & PSL & $\begin{array}{c}\text { Tramitando em } \\
\text { Conjunto }\end{array}$ \\
\hline PL 1298/2019 & 2019 & Conservador & $\begin{array}{l}\text { Gênero na } \\
\text { sociedade }\end{array}$ & Carlos Jordy & RJ & PSL & $\begin{array}{c}\text { Tramitando em } \\
\text { Conjunto;Aguardand } \\
\text { o Definição } \\
\text { Encaminhamento }\end{array}$ \\
\hline PI . 2040/2019 & 2019 & Conservador & $\begin{array}{l}\text { Gênero na } \\
\text { Sociedade }\end{array}$ & Julian Lemos & PB & PSL & $\begin{array}{l}\text { Tramitando em } \\
\text { Conjunto }\end{array}$ \\
\hline 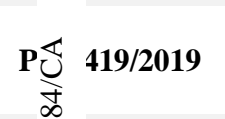 & 2019 & Conservador & $\begin{array}{l}\text { Gênero na } \\
\text { sociedade }\end{array}$ & Heitor Freire & $\mathrm{CE}$ & PSL & $\begin{array}{l}\text { Aguardando } \\
\text { Designação de } \\
\text { Relator }\end{array}$ \\
\hline$P_{\overparen{\lambda}}^{\infty} 492 / 2019$ & 2019 & Conservador & Gênero & Carla Zambelli & SP & PSL & Pronta para Pauta \\
\hline$P_{\circ}^{\curvearrowright} 664 / 2019$ & 2019 & Conservador & Ideologia de Gênero & Helio Lopes & RJ & PSL & $\begin{array}{c}\text { Tramitando em } \\
\text { Conjunto }\end{array}$ \\
\hline 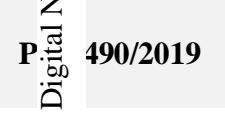 & 2019 & Conservador & $\begin{array}{l}\text { Gênero na } \\
\text { sociedade }\end{array}$ & Pr Eurico & $\mathrm{PE}$ & PATRIOTA & $\begin{array}{l}\text { Aguardando } \\
\text { Designação de } \\
\text { Relator }\end{array}$ \\
\hline P & 2019 & Conservador & $\begin{array}{c}\text { Orientação/Proteção } \\
\text { Sexual }\end{array}$ & Maria Rosas & SP & $\begin{array}{c}\text { REPUBLICANO } \\
\mathrm{S}\end{array}$ & $\begin{array}{c}\text { Apensado ao PL } \\
8907 / 2017\end{array}$ \\
\hline 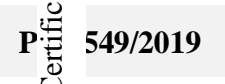 & 2019 & Conservador & $\begin{array}{c}\text { Orientação/Proteção } \\
\text { Sexual }\end{array}$ & $\begin{array}{l}\text { Alexandre } \\
\text { Frota }\end{array}$ & SP & PSL & $\begin{array}{l}\text { Tramitando em } \\
\text { Conjunto }\end{array}$ \\
\hline$P_{ْ}^{1} 412 / 2019$ & 2019 & Conservador & $\begin{array}{c}\text { Orientação/Proteção } \\
\text { Sexual }\end{array}$ & Filipe Barros & PR & PSL & $\begin{array}{c}\text { Tramitando em } \\
\text { Conjunto }\end{array}$ \\
\hline P己 & 2019 & Conservador & $\begin{array}{c}\text { Orientação/Proteção } \\
\text { Sexual }\end{array}$ & $\begin{array}{l}\text { Pr Sargento } \\
\text { Isidório }\end{array}$ & BA & AVANTE & $\begin{array}{c}\text { Aguardando } \\
\text { Despacho do } \\
\text { Presidente da Câmara } \\
\text { dos Deputados }\end{array}$ \\
\hline
\end{tabular}




\section{APÊNDICE D - Lista de iniciativas progressistas relacionadas à educação}

\begin{tabular}{|c|c|c|c|c|c|c|c|}
\hline Iniciativa & Ano & Caráter & Tema & $\begin{array}{l}\text { Primeiro } \\
\text { Autor }\end{array}$ & UF & Partido & Situação \\
\hline PL 1331/2003 & 2003 & Progressista & $\begin{array}{c}\text { Discussões sobre } \\
\text { questões relacionadas à } \\
\text { sexualidade na } \\
\text { sociedade }\end{array}$ & $\begin{array}{l}\text { Chico } \\
\text { Alencar }\end{array}$ & RJ & PSOL & Arquivada \\
\hline PL 7/2003 & 2003 & Progressista & $\begin{array}{l}\text { Educação sexual e/ou } \\
\text { questões de gênero }\end{array}$ & $\begin{array}{c}\text { Iara } \\
\text { Bernardi }\end{array}$ & SP & PT & Arquivada \\
\hline PL 414/2003 & 2003 & Progressista & $\begin{array}{c}\text { Saúde Sexual / } \\
\text { Planejamento Familiar }\end{array}$ & $\begin{array}{l}\text { Thelma de } \\
\text { Oliveira }\end{array}$ & MT & PSDB & Arquivada \\
\hline PL 4559/2004 & 2004 & Progressista & $\begin{array}{l}\text { Combate à violência } \\
\text { sexual / gênero } \\
\text { (mulher) }\end{array}$ & $\begin{array}{l}\text { Poder } \\
\text { Executivo }\end{array}$ & & & Transformada em Lei \\
\hline PL 3770/2004 & 2004 & Progressista & $\begin{array}{l}\text { Educação sobre } \\
\text { sexualidade e/ou } \\
\text { relações de gênero } \\
\text { (LGBT/Identidade) }\end{array}$ & $\begin{array}{l}\text { Eduardo } \\
\text { Valverde }\end{array}$ & RO & PT & Arquivada \\
\hline PL 6256/2005 & 2005 & Progressista & $\begin{array}{l}\text { Educação sobre } \\
\text { sexualidade e/ou } \\
\text { relações de gênero }\end{array}$ & $\begin{array}{l}\text { Remi } \\
\text { Trinta }\end{array}$ & MA & PL & $\begin{array}{l}\text { Tramitando em } \\
\text { Conjunto }\end{array}$ \\
\hline PL 584/2007 & 2007 & Progressista & $\begin{array}{l}\text { Educação sobre } \\
\text { sexualidade e/ou } \\
\text { relações de gênero }\end{array}$ & $\begin{array}{l}\text { Alice } \\
\text { Portugal }\end{array}$ & BA & PCdoB & $\begin{array}{l}\text { Tramitando em } \\
\text { Conjunto }\end{array}$ \\
\hline$\bigcup_{\forall}^{\varangle} 601 / 2007$ & 2007 & Progressista & $\begin{array}{l}\text { Educação sobre } \\
\text { sexualidade e/ou } \\
\text { relações de gênero }\end{array}$ & $\begin{array}{l}\text { Carlos } \\
\text { Abicalil }\end{array}$ & MT & PT & $\begin{array}{l}\text { Tramitando em } \\
\text { Conjunto }\end{array}$ \\
\hline$\stackrel{\infty}{\stackrel{\infty}{\simeq}}: 431 / 2007$ & 2007 & Progressista & $\begin{array}{l}\text { Educação sobre } \\
\text { sexualidade e/ou } \\
\text { relações de gênero }\end{array}$ & $\begin{array}{l}\text { Maria do } \\
\text { Rosário }\end{array}$ & $\mathrm{RS}$ & PT & Arquivada \\
\hline 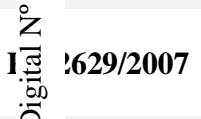 & 2007 & Progressista & $\begin{array}{l}\text { Educação sobre } \\
\text { sexualidade e/ou } \\
\text { relações de gênero }\end{array}$ & $\begin{array}{l}\text { Lídice da } \\
\text { Mata }\end{array}$ & BA & PSB & Arquivada \\
\hline 27/2007 & 2007 & Progressista & $\begin{array}{l}\text { Discussões sobre } \\
\text { questões relacionadas à } \\
\text { sexualidade na } \\
\text { sociedade }\end{array}$ & $\begin{array}{l}\text { Reginaldo } \\
\text { Lopes }\end{array}$ & MG & PT & Arquivada \\
\hline$\stackrel{1}{1}_{0}^{0} 3959 / 2008$ & 2008 & Progressista & Equidade de Gênero & $\begin{array}{c}\text { Poder } \\
\text { Executivo }\end{array}$ & & & $\begin{array}{l}\text { Transformado em } \\
\text { Lei }\end{array}$ \\
\hline 1041/2010 & 2010 & Progressista & Superação de Tabus & $\begin{array}{l}\text { Edigar Mão } \\
\text { Branca }\end{array}$ & BA & PV & Arquivada \\
\hline $\begin{array}{l}P \\
\text { PL 4753/2012 }\end{array}$ & 2012 & Progressista & $\begin{array}{l}\text { Educação sobre } \\
\text { sexualidade e/ou } \\
\text { relações de gênero }\end{array}$ & $\begin{array}{l}\text { Benedita da } \\
\text { Silva }\end{array}$ & RJ & PT & $\begin{array}{l}\text { Aguardando } \\
\text { Apreciação pelo } \\
\text { Senado Federal }\end{array}$ \\
\hline PL 4468/2012 & 2012 & Progressista & $\begin{array}{l}\text { Educação sobre } \\
\text { sexualidade e/ou } \\
\text { relações de gênero }\end{array}$ & Liliam Sá & RJ & PSD & Arquivada \\
\hline PL 5002/2013 & 2013 & Progressista & Equidade de gênero & $\begin{array}{l}\text { Jean } \\
\text { Wyllys }\end{array}$ & RJ & PSOL & Arquivada \\
\hline PL 2805/2015 & 2015 & Progressista & $\begin{array}{l}\text { Educação sobre } \\
\text { sexualidade e/ou } \\
\text { relações de gênero }\end{array}$ & $\begin{array}{l}\text { Erika } \\
\text { Kokay }\end{array}$ & DF & PT & $\begin{array}{l}\text { Aguardando } \\
\text { Designação de } \\
\text { Relator }\end{array}$ \\
\hline PL 3795/2015 & 2015 & Progressista & $\begin{array}{l}\text { Educação sobre } \\
\text { sexualidade e/ou } \\
\text { relações de gênero } \\
\text { (mulher) }\end{array}$ & $\begin{array}{l}\text { Ezequiel } \\
\text { Teixeira }\end{array}$ & RJ & PMB & $\begin{array}{l}\text { Tramitando em } \\
\text { Conjunto }\end{array}$ \\
\hline PL 962/2015 & 2015 & Progressista & $\begin{array}{l}\text { Educação sobre } \\
\text { sexualidade e/ou } \\
\text { relações de gênero } \\
\text { (mulher) }\end{array}$ & $\begin{array}{l}\text { Conceição } \\
\text { Sampaio }\end{array}$ & $\mathrm{AM}$ & PP & $\begin{array}{l}\text { Tramitando em } \\
\text { Conjunto }\end{array}$ \\
\hline PL 882/2015 & 2015 & Progressista & Direitos Reprodutivos e & $\begin{array}{l}\text { Jean } \\
\text { Wyllys }\end{array}$ & RJ & PSOL & $\begin{array}{l}\text { Tramitando em } \\
\text { Conjunto }\end{array}$ \\
\hline
\end{tabular}




\begin{tabular}{|c|c|c|c|c|c|c|c|}
\hline PL 3340/2019 & 2019 & Progressista & $\begin{array}{l}\text { Educação sobre } \\
\text { sexualidade e/ou } \\
\text { relações de gênero } \\
\text { (mulher) }\end{array}$ & Lauriete & ES & PL & $\begin{array}{c}\text { Apensado ao PL } \\
852 / 2019\end{array}$ \\
\hline PL 10613/2018 & 2018 & Progressista & $\begin{array}{l}\text { Educação sobre } \\
\text { sexualidade e/ou } \\
\text { relações de gênero }\end{array}$ & Fábio Trad & MS & PSD & $\begin{array}{c}\text { Apensado ao PL } \\
10207 / 2018\end{array}$ \\
\hline PL 10207/2018 & 2018 & Progressista & $\begin{array}{l}\text { Educação sobre } \\
\text { sexualidade e/ou } \\
\text { relações de gênero }\end{array}$ & Aureo & RJ & SD & $\begin{array}{l}\text { Tramitando em } \\
\text { Conjunto }\end{array}$ \\
\hline PL 3573/2019 & 2019 & Progressista & $\begin{array}{l}\text { Combate à violência } \\
\text { sexual / gênero }\end{array}$ & $\begin{array}{l}\text { Fábio } \\
\text { Henrique }\end{array}$ & SE & PDT & $\begin{array}{c}\text { Apensado ao PL } \\
852 / 2019\end{array}$ \\
\hline PL 3574/2019 & 2019 & Progressista & $\begin{array}{l}\text { cação sobre } \\
\text { sexualidade e/ou } \\
\text { relações de gênero } \\
\text { (mulher) }\end{array}$ & $\begin{array}{l}\text { Fábio } \\
\text { Henrique }\end{array}$ & SE & PDT & $\begin{array}{c}\text { Apensado ao PL } \\
1447 / 2019\end{array}$ \\
\hline PL 4589/2019 & 2019 & Progressista & $\begin{array}{l}\text { Combate à violência } \\
\text { sexual / gênero }\end{array}$ & $\begin{array}{l}\text { Emanuel } \\
\text { Pinheiro } \\
\text { Neto }\end{array}$ & MT & PTB & $\begin{array}{c}\text { Apensado ao PL } \\
3574 / 2019\end{array}$ \\
\hline PL 852/2019 & 2019 & Progressista & Educação LGBT & $\begin{array}{c}\text { Sâmia } \\
\text { Bomfim }\end{array}$ & SP & PSOL & $\begin{array}{c}\text { Apensado ao PL } \\
598 / 2019\end{array}$ \\
\hline PL 3741/2019 & 2019 & Progressista & Educação LGBT & $\begin{array}{l}\text { Fernanda } \\
\text { Melchionna }\end{array}$ & $\mathrm{RS}$ & PSOL & $\begin{array}{l}\text { Tramitando em } \\
\text { Conjunto }\end{array}$ \\
\hline PL 4961/2019 & 2019 & Progressista & Educação LGBT & $\begin{array}{l}\text { Denis } \\
\text { Bezerra }\end{array}$ & $\mathrm{CE}$ & PSB & $\begin{array}{l}\text { Tramitando em } \\
\text { Conjunto }\end{array}$ \\
\hline PL 523/2019 & 2019 & Progressista & Equidade de Gênero & $\begin{array}{l}\text { Jandira } \\
\text { Feghali }\end{array}$ & RJ & PCdoB & $\begin{array}{l}\text { Tramitando em } \\
\text { Conjunto }\end{array}$ \\
\hline 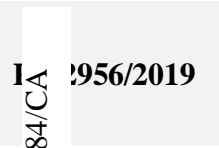 & 2019 & Progressista & $\begin{array}{c}\text { Educação sobre } \\
\text { sexualidade e/ou } \\
\text { relações de gênero } \\
\text { (mulher) }\end{array}$ & $\begin{array}{l}\text { Dra. Vanda } \\
\text { Milani }\end{array}$ & $\mathrm{AC}$ & $\begin{array}{l}\text { SOLIDARIEDAD } \\
\text { E }\end{array}$ & $\begin{array}{l}\text { Tramitando em } \\
\text { Conjunto }\end{array}$ \\
\hline 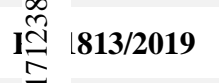 & 2019 & Progressista & Educação Sexual & $\begin{array}{l}\text { Rose } \\
\text { Modesto }\end{array}$ & MS & PSDB & $\begin{array}{l}\text { Tramitando em } \\
\text { Conjunto }\end{array}$ \\
\hline I $1318 / 2019$ & 2019 & Progressista & $\begin{array}{l}\text { Educação sobre } \\
\text { sexualidade e/ou } \\
\text { relações de gênero } \\
\text { (mulher) }\end{array}$ & $\begin{array}{l}\text { Aline } \\
\text { Gurgel }\end{array}$ & AP & PRB & $\begin{array}{l}\text { Tramitando em } \\
\text { Conjunto }\end{array}$ \\
\hline 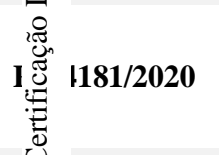 & 2020 & Progressista & $\begin{array}{c}\text { Educação sobre } \\
\text { sexualidade e/ou } \\
\text { relações de gênero } \\
\text { (mulher) }\end{array}$ & Deuzinho & $\mathrm{CE}$ & REPUBLICANOS & $\begin{array}{c}\text { Apensado ao PL } \\
10207 / 2018\end{array}$ \\
\hline 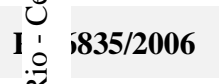 & 2006 & Progressista & Educação Pluralista & $\begin{array}{l}\text { Gilmar } \\
\text { Machado }\end{array}$ & MG & PT & $\begin{array}{c}\text { Transformado em } \\
\text { Lei }\end{array}$ \\
\hline I & 2008 & Progressista & Educação Pluralista & $\begin{array}{l}\text { Pompeo } \\
\text { Mattos }\end{array}$ & $\mathrm{RS}$ & PDT & $\begin{array}{c}\text { Apensado ao PL } \\
2431 / 2007\end{array}$ \\
\hline PL $3993 / 2008$ & 2008 & Progressista & Educação Pluralista & $\begin{array}{l}\text { Humberto } \\
\text { Souto }\end{array}$ & MG & PPS & $\begin{array}{c}\text { Apensado ao PL } \\
2082 / 2003\end{array}$ \\
\hline PL 5369/2009 & 2009 & Progressista & Educação Pluralista & $\begin{array}{l}\text { Vieira da } \\
\text { Cunha }\end{array}$ & $\mathrm{RS}$ & PDT & $\begin{array}{l}\text { Transformado em } \\
\text { Norma Jurídica }\end{array}$ \\
\hline PL 8035/2010 & 2010 & Progressista & $\begin{array}{l}\text { PNE (Educação } \\
\text { Pluralista) }\end{array}$ & $\begin{array}{c}\text { Poder } \\
\text { Executivo }\end{array}$ & DF & SEM PARTIDO & $\begin{array}{l}\text { Transformado em } \\
\text { Norma Jurídica }\end{array}$ \\
\hline PL 3887/2011 & 2011 & Progressista & Educação Pluralista & Reguffe & DF & PDT & $\begin{array}{c}\text { Apensado ao PL } \\
3993 / 2008\end{array}$ \\
\hline PLP 413/2014 & 2014 & Progressista & Educação Pluralista & $\begin{array}{l}\text { Ságuas } \\
\text { Moraes }\end{array}$ & MT & PT & Arquivada \\
\hline PL 8306/2014 & 2014 & Progressista & Educação Pluralista & $\begin{array}{l}\text { Angelo } \\
\text { Vanhoni }\end{array}$ & PR & PT & Arquivada \\
\hline PL 6005/2016 & 2016 & Progressista & Educação Pluralista & $\begin{array}{c}\text { Jean } \\
\text { Wyllys }\end{array}$ & RJ & PT & $\begin{array}{c}\text { Tramitando em } \\
\text { Conjunto;Tramitando } \\
\text { em Conjunto }\end{array}$ \\
\hline PL 6266/2016 & 2016 & Progressista & Educação Pluralista & $\begin{array}{l}\text { Pedro } \\
\text { Uczai }\end{array}$ & $\mathrm{SC}$ & PT & Devolvida ao Autor \\
\hline PL 6397/2016 & 2016 & Progressista & Educação Pluralista & $\begin{array}{l}\text { Pedro } \\
\text { Uczai }\end{array}$ & $\mathrm{SC}$ & PT & $\begin{array}{l}\text { Aguardando Parecer } \\
\text { do Relator na } \\
\text { Comissão de } \\
\text { Constituição e }\end{array}$ \\
\hline
\end{tabular}




\begin{tabular}{|c|c|c|c|c|c|c|c|}
\hline & & & & & & & $\begin{array}{c}\text { Justiça e de } \\
\text { Cidadania (CCJC) }\end{array}$ \\
\hline PL 10997/2018 & 2018 & Progressista & Educação Pluralista & $\begin{array}{c}\text { Dagoberto } \\
\text { Nogueira }\end{array}$ & MS & PDT & $\begin{array}{c}\text { Apensado ao PL } \\
7180 / 2014\end{array}$ \\
\hline PL 9689/2018 & 2018 & Progressista & Educação Pluralista & Jô Moraes & MG & PCdoB & Arquivada \\
\hline PL 1189/2019 & 2019 & Progressista & Educação Pluralista & $\begin{array}{c}\text { Natália } \\
\text { Bonavides }\end{array}$ & RN & PT & $\begin{array}{l}\text { Tramitando em } \\
\text { Conjunto;Tramitando } \\
\text { em Conjunto }\end{array}$ \\
\hline PL 375/2019 & 2019 & Progressista & Educação Pluralista & $\begin{array}{l}\text { Alexandre } \\
\text { Padilha }\end{array}$ & SP & PT & $\begin{array}{c}\text { Apensado ao PL } \\
7180 / 2014\end{array}$ \\
\hline PL 3159/2019 & 2019 & Progressista & Educação Pluralista & $\begin{array}{c}\text { Natália } \\
\text { Bonavides }\end{array}$ & RN & PT & $\begin{array}{c}\text { Apensada ao PL } \\
3179 / 2012\end{array}$ \\
\hline PL 5039/2019 & 2019 & Progressista & Educação Pluralista & $\begin{array}{l}\text { Igor } \\
\text { Kannário }\end{array}$ & BA & DEM & $\begin{array}{c}\text { Apensado ao PL } \\
10997 / 2018\end{array}$ \\
\hline PL 3875/2019 & 2019 & Progressista & Educação Pluralista & Zé Neto & BA & PT & $\begin{array}{l}\text { Tramitando em } \\
\text { Conjunto }\end{array}$ \\
\hline PL 1447/2019 & 2019 & Progressista & Educação Pluralista & $\begin{array}{c}\text { Rose } \\
\text { Modesto }\end{array}$ & MS & PSDB & $\begin{array}{c}\text { Apensado ao PL } \\
852 / 2019\end{array}$ \\
\hline PL 502/2019 & 2019 & Progressista & Educação Pluralista & $\begin{array}{l}\text { Talíria } \\
\text { Petrone }\end{array}$ & RJ & PSOL & $\begin{array}{c}\text { Tramitando em } \\
\text { Conjunto;Tramitando } \\
\text { em Conjunto }\end{array}$ \\
\hline PL 4938/2019 & 2019 & Progressista & Militarização Escolar & $\begin{array}{l}\text { Mário } \\
\text { Heringer }\end{array}$ & MG & PDT & $\begin{array}{l}\text { Aguardando Parecer } \\
\text { do Relator na } \\
\text { Comissão de } \\
\text { Segurança Pública e } \\
\text { Combate ao Crime } \\
\text { Organizado } \\
\text { (CSPCCO) }\end{array}$ \\
\hline$I_{\mho} i 134 / 2019$ & 2019 & Progressista & Militarização Escolar & $\begin{array}{c}\text { Ivan } \\
\text { Valente }\end{array}$ & SP & PSOL & $\begin{array}{c}\text { Apensado ao PL } \\
6134 / 2019\end{array}$ \\
\hline 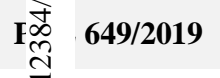 & 2019 & Progressista & Militarização Escolar & João Daniel & SE & PT & $\begin{array}{c}\text { Apensado ao PDL } \\
643 / 2019\end{array}$ \\
\hline F竞 $643 / 2019$ & 2019 & Progressista & Militarização Escolar & $\begin{array}{c}\text { Ivan } \\
\text { Valente }\end{array}$ & SP & PSOL & $\begin{array}{c}\text { Aguardando } \\
\text { Designação de } \\
\text { Relator na Comissão } \\
\text { de Educação (CE) }\end{array}$ \\
\hline I: & 2005 & Progressista & $\begin{array}{l}\text { Raça / Religião / } \\
\text { Educação }\end{array}$ & $\begin{array}{c}\text { Senado } \\
\text { Federal - } \\
\text { Paulo Paim }\end{array}$ & RS & PT & $\begin{array}{l}\text { Transformado em } \\
\text { Norma Jurídica }\end{array}$ \\
\hline 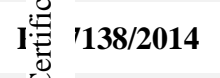 & 2014 & Progressista & Ensino Religioso & $\begin{array}{l}\text { Pedro } \\
\text { Uczai }\end{array}$ & SC & PT & Retirado pelo Autor \\
\hline نَ & 2015 & Progressista & $\begin{array}{c}\text { Valores Religiosos / } \\
\text { Laicidade }\end{array}$ & $\begin{array}{l}\text { Wadson } \\
\text { Ribeiro }\end{array}$ & MG & PCdoB & $\begin{array}{l}\text { Tramitando em } \\
\text { Conjunto }\end{array}$ \\
\hline I I & 2016 & Progressista & $\begin{array}{c}\text { Valores Religiosos / } \\
\text { Laicidade }\end{array}$ & $\begin{array}{l}\text { Wadson } \\
\text { Ribeiro }\end{array}$ & MG & PCdoB & $\begin{array}{l}\text { Tramitando em } \\
\text { Conjunto }\end{array}$ \\
\hline PL 4371/2016 & 2016 & Progressista & $\begin{array}{l}\text { Valores Religiosos / } \\
\text { Laicidade }\end{array}$ & $\begin{array}{l}\text { Erika } \\
\text { Kokay }\end{array}$ & DF & PT & $\begin{array}{c}\text { Apensado ao PL } \\
1089 / 2015\end{array}$ \\
\hline PL 9208/2017 & 2017 & progressista & Ensino Religioso & $\begin{array}{l}\text { Jean } \\
\text { Wyllys }\end{array}$ & RJ & PSOL & $\begin{array}{l}\text { Tramitando em } \\
\text { Conjunto }\end{array}$ \\
\hline
\end{tabular}




\section{APÊNDICE E - Lista de iniciativas parlamentares ambíguas relacionadas à educação}

\begin{tabular}{|c|c|c|c|c|c|c|c|}
\hline Iniciativa & Ano & Caráter & Tema & $\begin{array}{l}\text { Primeiro } \\
\text { Autor }\end{array}$ & UF & Partido & Situação \\
\hline PL 7001/2002 & 2002 & Ambíguo & $\begin{array}{l}\text { Liberdade Religiosa } \\
\text { / Laicidade }\end{array}$ & Dr. Evilásio & SP & PSB & $\begin{array}{c}\text { Apensado ao } \\
\text { PL 5/1999 }\end{array}$ \\
\hline PL 7030/2002 & 2002 & Ambíguo & $\begin{array}{l}\text { Liberdade Religiosa } \\
\text { / Laicidade }\end{array}$ & Dr. Evilásio & SP & PSB & $\begin{array}{c}\text { Apensado ao } \\
\text { PL 5/1999 }\end{array}$ \\
\hline PL 2171/2003 & 2003 & Ambíguo & $\begin{array}{l}\text { Liberdade Religiosa } \\
\text { / Laicidade }\end{array}$ & $\begin{array}{l}\text { Rubens } \\
\text { Otoni }\end{array}$ & GO & PT & $\begin{array}{c}\text { Transformado } \\
\text { em Norma } \\
\text { Jurídica }\end{array}$ \\
\hline PL 5446/2005 & 2005 & Ambíguo & $\begin{array}{l}\text { Liberdade Religiosa } \\
\text { / Laicidade }\end{array}$ & $\begin{array}{c}\text { Tarcísio } \\
\text { Zimmermann }\end{array}$ & RS & PT & $\begin{array}{l}\text { Apensado ao } \\
\text { PL 5/1999 }\end{array}$ \\
\hline PL 6304/2005 & 2005 & Ambíguo & $\begin{array}{l}\text { Liberdade Religiosa } \\
\text { / Laicidade }\end{array}$ & $\begin{array}{c}\text { Edinho } \\
\text { Montemor }\end{array}$ & SP & PSB & $\begin{array}{l}\text { Apensado ao } \\
\text { PL 5/1999 }\end{array}$ \\
\hline PL 6663/2006 & 2006 & Ambíguo & $\begin{array}{l}\text { Liberdade Religiosa } \\
\text { / Laicidade }\end{array}$ & $\begin{array}{l}\text { Carlos } \\
\text { Willian }\end{array}$ & MF & PTC & $\begin{array}{c}\text { Apensado ao } \\
\text { PL 5/1999 }\end{array}$ \\
\hline PL 6809/2006 & 2006 & Ambíguo & $\begin{array}{l}\text { Liberdade Religiosa } \\
\text { / Laicidade }\end{array}$ & Marco Maia & $\mathrm{RS}$ & PT & $\begin{array}{c}\text { Apensado ao } \\
\text { PL 5/1999 }\end{array}$ \\
\hline PL 4356/2016 & 2016 & Ambíguo & $\begin{array}{l}\text { Liberdade Religiosa } \\
\text { / Laicidade }\end{array}$ & $\begin{array}{l}\text { Atila A. } \\
\text { Nunes }\end{array}$ & $\mathrm{RJ}$ & PSL & $\begin{array}{l}\text { Tramitando } \\
\text { em Conjunto }\end{array}$ \\
\hline PL 4354/2016 & 2016 & Ambíguo & $\begin{array}{l}\text { Liberdade Religiosa } \\
\text { / Laicidade }\end{array}$ & $\begin{array}{l}\text { Atila A. } \\
\text { Nunes }\end{array}$ & $\mathrm{RJ}$ & PSL & $\begin{array}{l}\text { Tramitando } \\
\text { em Conjunto }\end{array}$ \\
\hline PL 850/2019 & 2019 & Conservador & $\begin{array}{l}\text { Liberdade Religiosa } \\
\text { / Laicidade }\end{array}$ & Jesus Sérgio & $\mathrm{AC}$ & PDT & $\begin{array}{l}\text { Tramitando } \\
\text { em Conjunto }\end{array}$ \\
\hline PL 6238/2019 & 2019 & Ambíguo & $\begin{array}{l}\text { Liberdade Religiosa } \\
\text { / Laicidade }\end{array}$ & $\begin{array}{c}\text { Celso } \\
\text { Russomanno }\end{array}$ & SP & REPUBLICANOS & $\begin{array}{l}\text { Apensado ao } \\
\text { Pl 4356/2016 }\end{array}$ \\
\hline PL 4188/2020 & 2020 & Ambíguo & $\begin{array}{l}\text { Liberdade Religiosa } \\
\text { / Laicidade }\end{array}$ & $\begin{array}{l}\text { Cezinha de } \\
\text { Madureira }\end{array}$ & SP & PSD & $\begin{array}{l}\text { Apensado ao } \\
\text { Pl 4356/2016 }\end{array}$ \\
\hline PL 4024/2015 & 2015 & Ambíguo & Educação Sexual & $\begin{array}{l}\text { Marcelo } \\
\text { Belinati }\end{array}$ & PR & PP & $\begin{array}{c}\text { Apensado ao } \\
\text { PL } \\
1911 / 2011\end{array}$ \\
\hline PL 10813/2018 & 2018 & Ambíguo & Educação Sexual & $\begin{array}{l}\text { Mariana } \\
\text { Carvalho }\end{array}$ & RO & PSDB & $\begin{array}{l}\text { Aguardando } \\
\text { Parecer }\end{array}$ \\
\hline PL 9671/2018 & 2018 & Ambíguo & $\begin{array}{l}\text { Educação contra } \\
\text { Abuso Sexual }\end{array}$ & $\begin{array}{l}\text { Prof. Gedeão } \\
\text { Amorim }\end{array}$ & $\mathrm{AM}$ & PMDB & $\begin{array}{l}\text { Pronta para } \\
\text { Pauta }\end{array}$ \\
\hline PL 2983/2019 & 2019 & Ambíguo & $\begin{array}{l}\text { Educação contra } \\
\text { Abuso Sexual }\end{array}$ & Julian Lemos & $\mathrm{PB}$ & PSL & $\begin{array}{l}\text { Tramitando } \\
\text { em Conjunto }\end{array}$ \\
\hline PL 5854/2019 & 2019 & Ambíguo & Autoridade Familiar & Helio Lopes & $\mathrm{RJ}$ & PSL & $\begin{array}{c}\text { Apensado ao } \\
\text { PL } \\
7180 / 2014\end{array}$ \\
\hline
\end{tabular}

